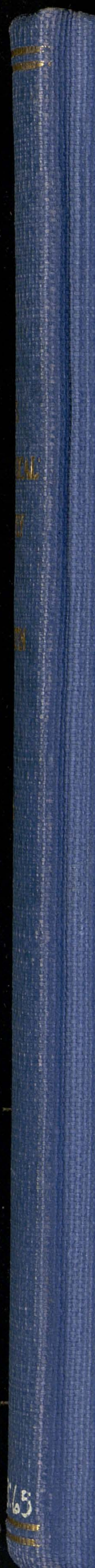



Ame-1783

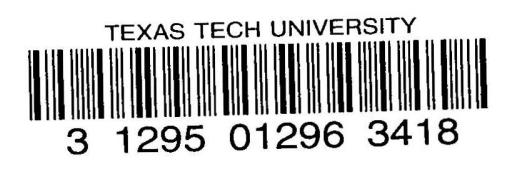

$$
212.2: 65
$$







\title{
$119.3: 45$
}

DEPARTMENT OF THE INTERIOR

\section{BULLETIN}

OF THE

\section{UNITED STATES}

\section{GEOLOGICAL SURVEY}

\author{
No. 65
}

STRATIGRAPHY OF THE BITUMINOUS COAL FIELD IN PENNSYLVANIA, OHIO, AND WEST VIRGINIA

WASHINGTON

GOVERNMENT PRINTING OFFIOE 



\section{IIBRARY CATALOGUE SLIPS.}

United States. Department of the interior. (U. S. geological 8urvey.) Department of the interior | - | Bulletin | of the | United States | geological survey | no. 65 | [Seal of the department] |

Washington | government printing office | 1891

Second title: United States geological survey | J. W. Powell, director | - Stratigraphy | of the | bituminous coal field | of | Pennsylvania, Ohio, and West Virginia | by | Israel C. White | [Vignette] |

Washington | government printing office | 1891

8. 212 pp. $11 \mathrm{pl}$.

White (Israel C.).

United States geological survey | J. W. Powell, director | - |

Stratigraphy | of the | bituminous coal field | of $\mid$ Pennsylvania, Ohio, and West Virginia | by | Israel C. White | [Vignette]

Washington | government printing office | 1891

8०. 212 pp. $11 \mathrm{pl}$.

[UNited States. Department of the interior. (U. S. geological survey.) Bulletin 65.]

United States geological survey | J. W. Powell, director | - | Stratigraphy | of the | bituminous coal field | of | Pennsylvania, Ohio, and West Virginia | by | Israel C. White | [Vignette]

Washington | government printing office | 1891

80. $212 \mathrm{pp} .11 \mathrm{pl}$.

[United States. Department of the interior. (U.S. geological survey.) Bulletin 65.] 



\section{A D V ERTISEM $\mathbf{N}$ T.}

[Bulletin No. 65.]

The publications of the United States Geological Survey are issued in accordance with the statute approved March 3, 1879, which declares that-

"The publications of the Geological Surrey shall consist of the annual report of operations, geological and economic maps illustrating the resources and classification of the lands and reports upon general and economic geology and paleontology. The annual report of operations of the Geological Survey shall accompany the annual report of the Secretary of the Interior. All special memoirs and reports of said Survey shall be issued in uniform quarto series if deemed necessary by the Director, but otherwise in ordinary octavos. Three thousand copies of each shall be published for scientific exchanges and for sale at the price of publication; and all literary and cartographic materials received in exchange shall be the property of the United States and form a part of the library of the organization; and the money resulting from the sale of such publications shall be covered into the Treasury of the United States."

On July 7,1882 , the following joint resolution, referring to all Government publications, was passed by Congress:

"That whenever any document or report shall be ordered printed by Congress, there shall be printed, in addition to the number in each case stated, the 'usual number' $(1,900)$ of copies for binding and distribution among those entitled to receive them."

Except in those cases in which an extra number of any publication has been supplied to the Survey by special resolution of Congress or has been ordered by the Secretary of the Interior, this office has no copies for gratuitous distribution.

\section{ANNUAL REPORTS.}

I. First Annual Report of the United States Geological Survey, by Clarence King. 1880. 80.79 F . 1 map.-A preliminary report describing plan of organization and publications.

II. Second Annual Report of the United States Geological Survey, 1880-'81, by J. W.Powell. 1882. $80.1 \mathrm{v}, 588 \mathrm{pp} .62 \mathrm{pl} .1$ map.

III. Third Annual Report of the United States Geological Survey, 1881-'82, by J. W. Powell. 1883. 80. xviii, 564 pp. $67 \mathrm{pl}$. and maps.

IV. Fourth Annual report of the United States Geological Survey, 1882-'83, 'by J. W. Powell. 1884. 8. $. x \times x i i, 473 \mathrm{pp} .85 \mathrm{pl}$. and maps.

V. Fifth Annual Report of the United States Geological Survey, 1883-'84, by J. W. Powell. 1885. $80 . \quad x x x v i, 469 \mathrm{pp} .58 \mathrm{pl}$, and maps.

VI. Sixth Annual Report of the United States Geological Survey, 1884-'85, by J. W. Powell. 1885. 8. $x x i x, 570 \mathrm{pp} .65 \mathrm{pl}$. and maps.

VII. Seventh Anuual Report of the United States Geological Survey, 1885-'86, by J. W. Powell. 1888 80. $\mathrm{xx}, 656 \mathrm{pp} .71 \mathrm{pl}$. and maps.

VIII. Eighth Annual Report of the United States Geological Survey, 1886-'87, by J. W. Powell. 1889 . 80 2v. xix, 474, xii pp. 53 pl. and maps; 1 p. l. 475-1063 pp. 54-76 pl. and maps.

IX. Ninth Annual Report of the United States Geological. Survey, 1887-'88, by J. W.Powell. 1889. 80 . xiii, 717 pp. $88 \mathrm{pl}$. and maps.

X. Tenth Annual Report of the United States Geological Survey, 1888-'89, by J. W. Powell. 1890. $8^{\circ} .2$ v. $x \nabla, 774$ pp. 98 pl. and maps; viii, 123 pp.

The Elerenth Annual Report is in press.

\section{MONOGRAPHS.}

I. Lake Bonneville, by Grove Karl Gilbert. $1890.44^{\circ} . \quad \mathrm{xx}, 428 \mathrm{pp} .51 \mathrm{pl} .1$ map. Price $\$ 1.50$.

II. Tertiary History of the Grand Cañon District, with atlas, by Clarence E. Dutton, Capt. U. S. A. 1882. $4^{\circ}$. xiv, $264 \mathrm{pp}$. $42 \mathrm{pl}$. and atlas of 24 sheets folio. Price $\$ 10.00$.

III. Geology of the Comstock Lode and the Washoe District, with atlas by George F. Becker. 1882. 40. $\mathrm{x}, 422 \mathrm{pp} .7 \mathrm{pl}$. and atlas of 21 sheets folio. Price $\$ 11.00$.

IV. Comstock Mining and Miners, by Eliot Lord. 1883. $4^{\circ}$. xiv, 451 pp. 3 pl. Price $\$ 1.50$. 
V. The Copper-Bearing Rocks of Lake Superior, by Roland Duer Irving. 1883. $4^{\circ}$. $\quad$ xvi, 464 pp. 15 l. 29 l. anil maps. Price $\$ 1.8$.

VI. Contributions to the Knowledge of, the Older Mesozoic Flora of Virginia, by William Morris Fontaine. 1883, 40. xi, 144 pp. 54 l. $54 \mathrm{pl}$. Price $\$ 1.05$.

VIr. Silver-Lead Deposits of Eureka, Nerada, by Joseph Story Curtis. $1884 . \quad 4^{\circ} . \quad$ xiii, 200 pp. 16 pl. Price $\$ 1.20$.

VIII. Paleontulogy of the Eurcka District, by Charles Doolittle Walcott. $\quad 1884 . \quad 4^{\circ} . \quad$ xiii, $298 \mathrm{pp}$. 24 1. 24 pl. Price $\$ 1.10$.

IX. Brachiopoda and Lamellibranchiata of the Raritan Clays and Greensand Marls of New Jersey; by Robert P. Whitfield. 1885. 40. xx, $338 \mathrm{pp}$. $35 \mathrm{yl}$. 1 map. Price $\$ 1.15$.

X. Dinocerata. A Monograph of an Extinct Order of Gigantic Mammals, by Othniel Charles Marsh; 1886. 40. xviii, 243 pp. 56 l. $56 \mathrm{pl}$. Price \$2.70.

XI. Geological History of Lake Labontan, a Quaternary Lake of Northwestern Nevada, by Israel Cook Fussell. 1885. 40. xiv, 288 pp. 46 pl, and maps. Price $\$ 1.75$.

XII. Geology and Mining Industry of Leadville, Colorado, with atlas, by Samuel Franklin Emmons. 1886. $4^{\circ}$. $\mathrm{xxix}, 770 \mathrm{pp}$. $45 \mathrm{pl}$. and atlas of 35 sheets folio. Price $\$ 8.40$.

XIII. Geology of the Quicksilver Deposits of the Pacific Slope, with atlas, by George F. Becker. 1888. $4^{\circ}$. xix, $486 \mathrm{pp} .7 \mathrm{pl}$, and atlas of 14 sheets folio. Price $\$ 2.00$.

XIV. Fossil Fishes and Fossil Plants of the Triassic Rocks of New Jersey and the Connecticut Valley, by John S. Newberry. 1888. 40. xiv, 152 p. 26 pl. Price $\$ 1.00$.

XV. The Potomate or Xounger Mesozoie Flora, by William Morris Fontaine. 1889. 40. xiv, 377 pp. $180 \mathrm{pl}$. Text and plates bound separately. Price $\$ 2.50$.

XYI. 'The Palcozoic Fishes of North America, by JoLn Strong Newberry. 1889. 40. 340 pp. 53 pl. Price\$1.00.

In preparation:

XVII. The Flora of the Dakota Group, a posthumous work, by Leo Lesquereux. Edited by F. H. Knowlton.

- Gasteropoda of the New Jersey Cretaceons and Eocene Marls, by R. P. Whitfield.

- The Penokee Iron-Bearing Serics of Northern Wisconsin and Michigan, by Roland D. Irving and C. li. Van Ilise.

- Mollusea aul Crustacea of the Miocene Formations of New Jersey, by R. P. Whitfield.

- Geology of the Eureka Mining District, Nerada, with atlas, by Arnold Hague.

- Sauropoda, by O. C. MLarsh.

- Stegosauria, by 0. C. Marsh.

- Brontotharidie, by O. C.Mrarsh.

- Report on the Denver Coal Basin, by S. F. Emmons.

- Report on Silver Cliff and Teu-ntile Mining Districts, Colorado, by S. F. Emmons.

- Flora of the Dakota Group, by J. S. Newberry.

- The Glacial Lake Arassiz, by Warren Upham.

\section{BULLETINS.}

1. On Hyperstlene-A udesito and on Triclinic Pyroxene in Augitic Rocks, by Whitman Cross, with a Geological sketch of Buftillo I'eaks, Colorato, by S. F. Emmons. 1883. 80. 42 pp. 2 pl. Price 10 cents. 2. Ciold a nil Silver Conversion l'ables, giving the coining values of troy ounces of fine metal, etc., com. puted by Albert Williams, jr. 1883. 8?. 8 pp. Price 5 cents.

3. Cn the Eossil Faunas of the Upper Devonian, along the meridian of $76^{\circ} 30^{\prime}$, from Tompkins County, New York. to Bralford County. Pennsylrania, by Henry S. Williams. 1884. $8^{\circ} .36$ pp. Price 5 cents.

4. On Mesozoic Fossils, by Charles A. White. 1884. $8^{\circ} .36$ pp. 9 pl. Price 5 cents.

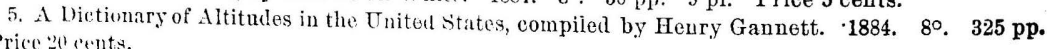
Price 20 cents.

6. Elesitions in the Dominion of Canada, by J. W. Spencer. 1884. $8^{\circ} .43$ pp. Price 5 cents.

7. Mapoteca troblogica Aruericana. A Catalogne of Geological Mapis of America (North and Sonth), 1752-1881, in goographic and chronologic oriler, ly Jules Marcon and John Bellinap Marcou. 1884. Bo. 181 pp. P'rice 10 cents.

8. On Fecondary Fulargements of Mineral Fragments in Certain Rocks, by R. D. Irving and C. R. Van Hise. 188t. co. 56 pp. 6 pll. Prico 10 eents.

9. A report of work done in the Washington laboratory during the fiscal sear 1883-'84. F. W. Clarke, chief rhemist. 'T. MI. Chatard, assistant chemist. $1884.88^{\circ} 40$ pp. Price 5 cents. 10. On the Cambrian Faunas of North America. Preliminary studies, by Charles Doolittle Walcott.
1884. $8^{\circ}$. 74 pl. 10 pl. I'rico 5 cents.

11. On the Quaternary and lecent Mollusea of the Great Basin ; witb Descriptions of New Forms, by
R. Ellsworth Call. Introduch by a R. Ellsworth Call. Introduced by a sketch of the Quaternary Lakes of the Great Basin, by G. K.
Gilbert. 188. 80. 66 pp. $6 \mathrm{pl}$. Price 5 cents.

12. A Crystallowaphic Stuly of the Thinulite of Lake Lahontan, by Edward S. Dana. 1884.80. $34 \mathrm{pp} .3 \mathrm{pl}$. Price 5 cents. 
13. Boundaries of the United States and of the several States and Ter ritories, with a Historical Sketch of the Territorial Changes, by Henry Gannett. $1885.8^{\circ} .135$ pp. Price 10 cents.

14. The Electrical and Magnetic Properties of the Iron-Carburets, by Carl Baras and Vincent Stroubal. $1885.8^{\circ} .238 \mathrm{pp} . \quad$ Price 15 cents.

15. On the Mesozoic and Cenozoic Paleontology of California, by Charles A. White. 1885. 80. 3. pi. Price 5 cents.

if. On the Higher Deronian Faunas of Ontario County, New York, by John M. Clarke. $1885.8^{\circ}$. f6 op. 3 pl. Price 5 cents.

17. On the Development of Crystallization in the Igneous Rocks of Washoe, Nevada, with Notes on the Geologs of the District, by Arnold Hague and Joseph P. Iddings. 1885. $8^{\circ}$. 44 pp. Price 5 ceuts.

18. On Marine Eocene, Fresh-water Miocene, and other Fossil Mollusca of Western North America, by Charles A. White. $1885.80,26$ pp. 3 pl. Price 5 cents.

19. Notes on the Stratigraphy of California, by George F. Becker. 1885. $8^{\circ}$. 28 pp. Price 5 cents. 20. Contributions to the Mineralogy of the Rocky Mountains, by Whitman Cross and W. F. Hille. brand. 1885 . $80.114 \mathrm{pp}$. $1 \mathrm{pl}$. Price 10 cents.

21. The Lignites of the Great Sioux Reservation. A Report on the Region between the Grand and Moreau Rivers, Dakota, by Bailey Willis. 1885 . $8^{\circ} .16$ pp. 5 pl. Price 5 cents.

22. On New Cretaceous Fossils from California, by Charles A. White. 1885. 80.25 pp. 5 pl. Price 5 cents.

23. Observations on the Junction between the Eastern Sandstone and the Keweenaw Series on Ke weenaw Point, Lake Superior, by R. D. Irving and T. C. Chamberlin. 1885. $80^{\circ} 124 \mathrm{pj}$. $17 \mathrm{pl}$. Price 15 cents.

24. List of Marine Mollusca, comprising the Quaternary Fossils and recent forms from American Localities between Cape Hatteras and Cape Roque, including the Bermudas, by William Healey Dall. 1885. 80. $336 \mathrm{pp}$. Price 25 cents.

25. The Present Technical Condition of the Steel Industry of the United States, by Phineas Barnes. 1885. $8^{\circ}$. $85 \mathrm{pp}$. Price 10 cents.

26. Copper Smelting, by Henry M. Howe. 1885. 8०. 107 pp. Price 10 cents.

27. Report of work done in the Division of Chemistry and Physics, mainly during the fiscal year 1884-'85. $1886.8^{\circ} .80$ pp. Price 10 cents.

28. The Gabbros and Associated Hornblende Rocks occurring in the Neighborhood of Baltimore, Maryland, by George Huntington Williams. $1886.8^{\circ} .78$ pp. 4 pl. Price 10 cents.

29. On the Fresh-water Invertebrates of the North American Jurassic, by Charles A. White. 1886. 8०. 41 pp. 4 pl. Price 5 cents.

30. Second Contribution to the Studies on the Cambrian Faunas of North America, by Charles Doo. little Walcott. $1886.8^{\circ} .369$ pp. 33 pl. Price 25 cents.

31. Systematic Review of our Present Knowledge of Fossil Insects, inclnding Myriapods and Arachnids, by Samuel Hubbard Scudder. 1886. $8^{\circ}$. 128 pp. Price 15 cents.

32. Lists and Analyses of the Mineral Springs of the United States; a Preliminary Stady, by Alvert C. Peale. 1886 . $8^{\circ}$. $235 \mathrm{pp}$. Price 20 cents.

33. Notes on the Geology of Northern California, by J.S. Diller. 1886. $8^{\circ}$. 23 pp. Price 5 cents. 34. On the relation of the Laramie Molluscan Fauna to that of the succeeding Fresh-water Eocene and other groups, by Charles A. White. 1886 . $8^{\circ} .54 \mathrm{pp} .5 \mathrm{pl}$. Price 10 cents.

35. Phjsical Properties of the Iron-Carburets, by Carl Bar us and Vincent Stroubal. $1886 . \quad 80.62$ pp. Price 10 cents.

36. Subeidence of Fine Solid Particles in Liquids, by Carl Barus. 1886.80 .58 pp. Price 10 cents.

3i. Types of the Laramie Flora, by Lester F. Ward. $1887.8^{\circ} .354$ pp. 57 pl. Price 25 cents.

38. Peridotite of Elliott County, Kentucky, by J.S. Diller. $1887.8^{\circ}, 31$ pp. 1 pl. Price 5 cents.

39. The Upper Beaches and Deltas of the Glacial Lake Agassiz, by Warren Upham. 1887.80 .84 pp. 1 pl. Price 10 cents.

40. Changes in River Courses in Washington Territory due to Glaciation, by Bailey Willis. 1887. 8. 10 pp. 4 pl. Price 5 cents.

41. On the Fossil Faunas of the Upper Deronian-the Genesee Section, New York, by Henry S. Williams. $1887.8^{\circ} .121 \mathrm{pp} .4 \mathrm{pl}$. Price 15 cents.

42. Report of work done in the Division of Chemistry and Physics, mainls during the fiscal year 1885-'6. F. W. Clarke, chief chemist. 1887. $8^{\circ} .152 \mathrm{pp.} 1 \mathrm{pl}$. Price 15 cents.

43. Tertiary and Cretace ous Strata of the Tuscaloosa, Tombigbee, and Alabama Rivers, by Eugene A. Smith and Lawrence C. Johnson. $1887.8^{\circ} .189$ pp. 21 pl. Price 15 cents.

44. Billiography of North American Geology for 1886, by Nelson H. Darton. $1887.8^{\circ}$. 35 pp. Price 5 cents.

45. The Present Condition of Knowledge of the Geology of Texas, by Robert T. Hill. 1887. 80.94 pp. Price 10 cents.

46. Nature and Origin of Deposits of Phosphate of Lime, by B. A. F. Penrose,jr., with an Introdue. tiou by N.S. Shaler. 1888. 80.143 pp. Price 15 cents. 
47. Analyses of Waters of the Yellowstone National Park, with an Account of the Methods of Anal. ysis employed, by Frank Anstin Gooch and James Edrard Whitfield. 1888. $8^{\circ}$. 84 pp. Price 10 cents.

48. On the Form and Position of the Sea Level, by Robert Simpson Woodward. 1888. 80.88 pp. Price 10 cents.

49. Latitules and Longitndes of Certain Points in Missouri, Kansas, and New Mexico, by Robert Simpson Wondward. $1889.8^{\circ} .133 \mathrm{pp}$. Price 15 cents.

50. Formulas and T'ables to facilitate the Construction and Use of Maps, by Robert Simpson Woodward. 1889. $8^{\circ}$. 124 pp. Price 15 cents.

51. On Invertebrate Fossils from the Pacifie Coast, by Charles Abiathar White. 1889. 80. $102 \mathrm{pp}$.

14 pl. Price 15 cents.

52. Subaërial Decay of Rocks and Origin of the Red Color of Certain Formations, by Israel Cook Russell. $1889.8^{\circ} .65$ pp. 5 pl. Price 10 cents.

53. The Geology of Santucket, by Nathaniel Southgate Shaler. $1889 . \quad 8^{\circ} .55$ pp. 10 pl. Price 10 cents.

54. On the Thermo-Electric Measurement of High Temperatures, by Carl Barus. $\quad 1889 . \quad 80 . \quad 313 \mathrm{pp}$. incl. 1 pl. 11 pl. Price 25 cents.

55. Report of work done in the Division of Chemistry and Physics, mainly during the flscal Jear 1886--87. Frank Wirglesworth Clarke, chief ohemist. $1889.80 .96 \mathrm{pp}$. Price 10 cents.

56. Fossil Wood and Lignite of the Potomac Formation, by Frank Hall Knowlton. 1889. $8^{\circ} .72$ pp.

7 pl. Price 10 cents.

57. A Geological Reconnaissance in Southwestern Kansas, by Robert Hay. $1890 . \quad 80.49$ pp. 2 pl. Price 5 cents.

58. The Glacial Bumdary in Western Pennsylvania, Ghio, Kentucky, Indiana, and Illinois, by George Frederick Wriglit, with an introduction by Thomas Chrowder Chamberlin. 1890. $80.112 \mathrm{pp}$. incl. $1 \mathrm{pl} .8 \mathrm{pl}$. I'rice 15 cents.

59. The Gabbros and Associated Rocks in Delaware, by Frederick D. Chester. 1890. $8^{\circ} .45$ pp. 1 pl. Price 10 cents.

60. lieport of work done in the Dirision of Chemistry and Physics, mainly during the fiscal year 1887-'S8. F. W. Clarko, chief chemist. 1890. 8०. 174 pp. Price 15 cent.

61. Contributions to the Mineralogy of the Pacific Coast, by William Harlow Melville and Waldemar Lindurem, 1890. $8^{\circ}$. 40 pp. 3 pl. Price 5 cents.

62. The Greenstono Schist Areas of tho Menominee and Marquette Regions of Michigan; a contribution to the subject of dynamic metamorphism in cruptive rocks, by George Huntington Williams; with an introduction by Roland Dner Irving. 1890. $8^{\circ} .241 \mathrm{pp} .16 \mathrm{pl}$. Price 30 cents.

68. A Bibliography of Paleozoic Crustacen from 1698 to 1889 , including a list of North American species and a systematic arrangement of genera, by Anthons W. Vogdes. 1890. $8^{\circ}$. 177 pp. Price 15 ceuts.

64. A report of work done in the Division of Chemistry and Physics, mainly during the fiscal year 1888-'89. F. W. Clarke, chief chemist. $1890.8^{\circ} .60$ pp. Price 10 cents.

65. Stratigraphy of the Bituminous Coal Field of Pennsylrania, Ohio, and West Virginia, by Israel C. White. 1891. 8c. 212 pp. 11 pl. Price 20 cents.

66. On a Group of Volcanic Rocks from the Tewan Mountains, New Mexico, and on the occurrence of I'rimary Quartz in certain Basalts, by Joseph Paxson Iddings. 1890. 80. 34 pp. Prce 5 cents.

67. The relations of the Traps of the Newark System in the New Jersey Resion, by Nelson Horatio Darton. $1890.8^{\circ} .82 \mathrm{pp}$. Price 10 cents.

68. Earthquakes in California in 1869, by James Edwarả Keeler. 1890. $8^{\circ}$, 25 pp. Price 5 cents. 69. A Classed and Annotated Biblioga aphy of Fossil Insects, by Samuel Hubbard Scudder. 1890: 80. 101 pp. Price 15 cents.

70. Report on Astronomical Work of 1889 and 1890, by Robert Simpson Woodward. 1890. 80. 79 pp. Price 10 cents.

71. Index to the Known Fossil Insects of the World, including Myriapods and Arachnids, by Samuel Hubbard Scudder. 1891. $8^{\circ}$. 744 pp. Price 50 cents.

In press:

72. Altitudes between Lake Superior and the Rocky Mountains, by Warren Upham. 1891. 229 pp. Price 20 cents.

73. The Viscosity of Solitis, by Carl Barus. 1891. $8^{\circ}$. xii, 139 pp. 6 pl. Price 15 cents.

74. The Minerals of North Carolina, by Frederick Augustus Genth. 1891. 8०. 119 pp. Price 15 cents.

75. Record of North America Geology for 1887 to 1889, inclusive, by Nelson Horatio Darton.

76. A Dictionary of Altitudes in tho United States (second edition), compiled by Henry Gannett.

77. The Texan Permian and its Mesozoic types of Fossils, by Charles A. White. 1891. $8^{\circ}$. 51 pp

4 pl. Price 10 cents.

78. A report of work tone in the Division of Chemistry and Physics, mainly during the fiscal Jêts

1889-90. F. W. Clarke, chief chemist. $1891.8^{\circ}$. 119 pp. Price 15 cents.

79. A Lato Volcanic Eruption in Northern California and its peculiar lava, by J. S. Diller. 
80. Correlation papers-Devonian and Carboniferous, by Herry Shaler Williams.

81. Correlation papers-Cambrian, by Charles Doolittle Walcott.

82. Correlation papers - Cretaceous, by Charles A. White.

In preparation:

- The Compressibility of Liquids, by Carl Barus.

- The Eruptive and Sedimentary Rocks on Pigeon Point, Minnesota, and their contact phenomena, by W. S. Bayley.

- A Bibliography of Paleobotany, by David White.

\section{STATISTICAL PAPERS.}

Mineral Resources of the United States, 1882, by Albert Willams, jr. 1883. 80. xvii, 813 pp. Price 50 cents.

Mineral Resources of the United States, 1883 and 1884, by Albert Williams, jr. 1885. $80 . \quad$ xiv, 1016 pp. Price 60 cents.

Mineral Resources of the United States, 1885. Division of Mining Statistics and Technology. 1886. 8. vii, $576 \mathrm{pp}$. Price 40 cents.

Mineral Resources of the United States, 1886, by David T. Day. 1887. $8^{\circ}$. viii, 813 pp. Price 50 cents.

Mineral Resources of the United States, 1887, by David T. Day. 1888. $8^{\circ}$. vii, 832 pp. Price 50 cents.

Mineral Resources of the United States, 1888, by David T. Day. 1890. 8०. vii, 652 pp. Price 50 cents.

In preparation :

Mineral Resources of the United States, 1889 and 1890.

The money received from the sale of these publications is deposited in the Treasary, and the Secretary of the Treasury declines to receive bank checks, drafts, or postage stamps; all remittances, there. fore, must be by POSTAL NOTE or MONET ORDER, made payable to the Librarian of the U.S. Geological Survey, or in CURRexcy, for the exact amount. Correspondence relating to the publications of the Survey should be addressed

TO THE Director OF THE

United Stateg Grological Survey,

Washington, D. C.

Washisgton, D. C., December, 1890. 



\section{BULLETIN}

OF THE

\section{UNITED STATES}

\section{GEOLOGICAL SURVEY}

$$
\text { No. } 65
$$

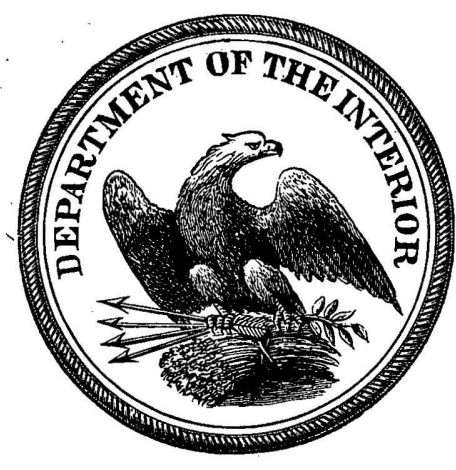

W A SH I N G TON.

GOVERNMENT PRINTING OFFIOE 

MAP TOO LARGE TO SCAN 



\section{CONTENTS.}

Page.

Chap. I.-Area, structure, and classification of the bituminous coal rocks.... 17

Chap. II. -The Permo-Carboniferous or Duukard Creek Measures ........... 20

Thickness, character, and extent ................................. 20

Section on Dunkard Creek, Greene Co., Pa................ 22

Section on Colvin's Run, Greene Co., Pa................... 23

Section in Aleppo Township, Greene Co., Pa................ 24

Section at Board Tree Tunnel, Marshall Co., W. Va ............ 25

Section at Bellton, Marshall Co., W. Va.................... 26

Section at New Martinsville, Wetzel Co., W. Va.............. 27

Section at Baresville, Monroe Co., Ohio .................... 28

Section in Liberty. Township, Washington Co., Ohio........... 29

Section at Washington, Washington Co., Pa ................ 29

Section near Taylorstown, Washington Co., Pa.............. 30

Characteristic horizons......................................... 30

The Windy Gap Limestone .................................. 30

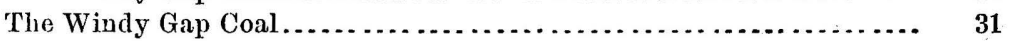

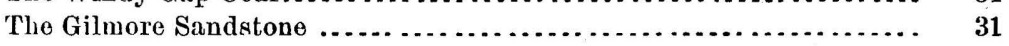

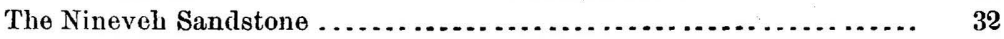

The Bellton Coal Group....................................... 32

The Nineveh Coal........................................... 32

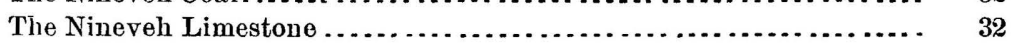

The Hostetter Coal....................................... 33

The Fish Creek Sandstone. .................................. 33

The Dunkard Coal ............................................ 33

The Jollytown Limestone .................................... 34

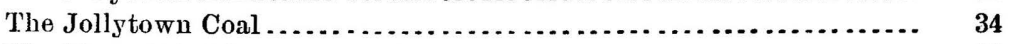

The Upper Washington Limestone........................... 35

The Middle Washington Limestone.......................... 35

The Washington "A" Coal .................................. 35

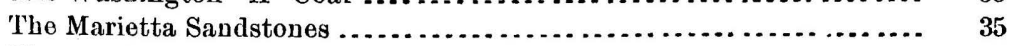

The Blacksville Limestone ................................. 36

The Lower Washington Limestone........................... $\quad 36$

The Washington Coal ...................................... 37

Section at Farmington, Marion Co., W. Va................. 37

Section on Willey Fork, Wetzel Co., W. Va ................ 38

Section near Brown's Mill, Monongalia Co., W. Va ............. 38

The Washington Sandstone ................................ 38

The Little Washington Coal.................................. 39

The Waynesburg " $\mathrm{B}$ " Coal ................................. 39

The Colvin's Run Limestone................................. 39

The Waynesburg "A" Coal . ................................. $\quad 39$

The Mount Morris Limestone.................................. 39

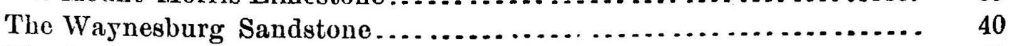

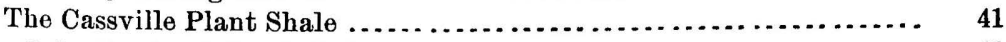

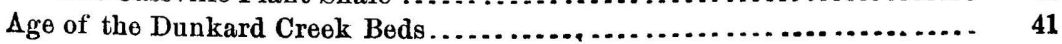


Criap. III. The Upper Coal Measures, or Monongahela River Series...........

Thickness, character, and extent ...............................

Section in Fayette and Westmoreland Cos., Pa.................

Section at Brownsville, Fayette Co., $\mathrm{Pa}$.......................

Section at West Brownsville, Washington Co., Pa..............

Section at Rice's Landing, Greene Co., Pa ......................

Section on Robinson's Run, Monongalia Co., W. Va .............

Section on Scott's Run, Monongalia Co., W. Va .................

Section on Buffalo Creek, Marion Co., W. Va ...................

Section at Clarksburg, Harrison Co., W. Va....................

Section on Chapline Hill, Wheeling, W. Va ...................

Section near Bellaire, Belmont Co., Ohio. ....................

Section at Moundsville, Marshall Co., W. Va ..................

Section on Pipe Creek, Belmont Co., Ohio....................

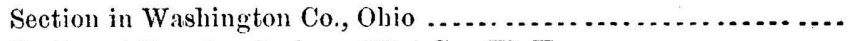

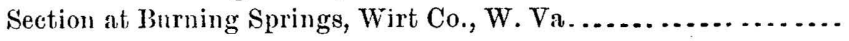

Section on Leading Creek, Gilmer Co., W. Va..................

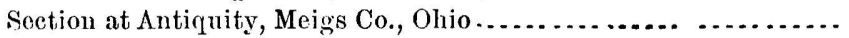

Section at IIartford City, Mason Co., W. Va...................

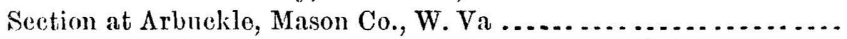

Section at month of Big Hurricane Creek, Putuan Co., W. Va ...

Section opposite Winfeld, Putuam Co., W. Va ...............

Section near Raymond City, Pntmam Co., W. Va ...............

Sestion in vicinity of Westernport, Allegany Co., Ma ...........

Characteristic horizons.

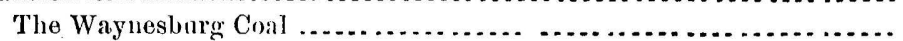

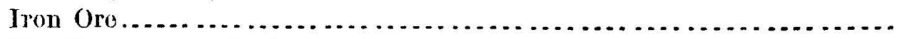

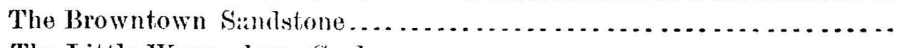

The Little Wayneshurg Coal . . . . . . . . . . . . . . . . . . . . . . .

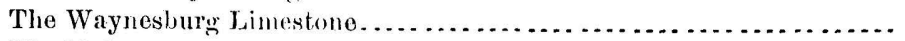

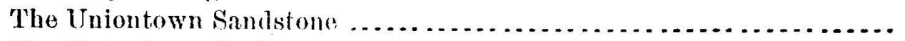

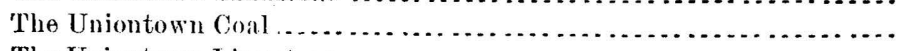

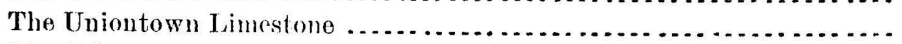

The "Great" Limestono .....................................

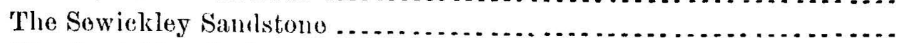

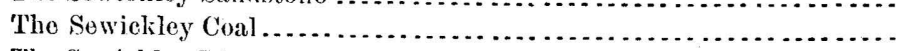

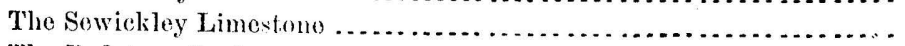

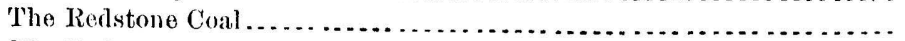

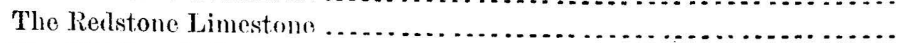

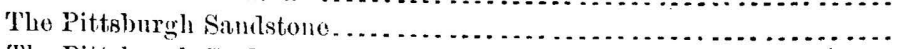

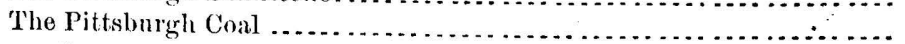

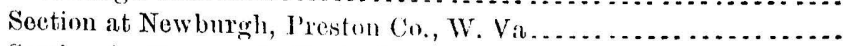

Section in Copeman's Knol, Preston Co., W. Va ..............

Section at Fairfax Knob, T'ucker Co., W. Ya.................

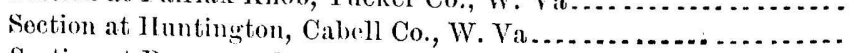

Sectiou at Pomeroy, Ohio

Section on Shade Creek, Meigs and Athens Cos., Ohio .............

Scetion on Federal Creek, Athens and Morgan Cos., Ohio.........

Section at Berry's mine, in IIomer 'Township, Morgan Co., Oliio ..

Section in Washington 'Township, Belmont Co., Ohio ............ Section at Heatherington's mine, at Bellaire, Belmont Co., Ohio... Section in Warren Township, Jefferson Co., Ohio...............

Section in German Township, Harrison Co., Ohio................

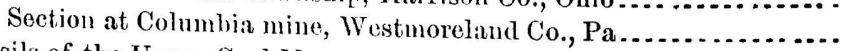

Fossils of the Upler Coal Measures. 
Crap. IV. The Barren Measures, or Elk River Series.................... 70

T'hickness, character, and extent ............................... 70

Section in Pittsburgh region ........................... 72

Section at Sewickley, Pa .................................. 73

Section on Dunbar Creek, Fayette Co., Pa ................. 74

Section at Ligonier, Westmoreland Co., Pa............... 75

Section in vicinity of Berlin, Somerset Co., Pa ............... 76

Section in Broad Top Basin, Bedford Co., Pa............... 76

Section opposite Steubenville, Ohio...................... 77

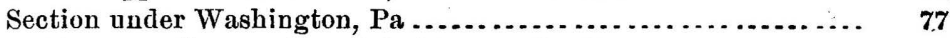

Section near Cannonsburg, Washington Co., Pa .............. 78

Section at Morgantown, W. Va ........................... 79

Section near Little Falls, Monongalia Co., W. Va.............. 80

Section at Newburg, Preston Co., W. Va................... 81

Section at Fairfax Knob, Tucker Co., W. Va ............... 82

Section in Guernsey Co., Ohio .......................... 83

Section at Burning Springs, Wirt Co., W. Va.............. 833

Section in vicinity of Huntington, W. Va................ 84

Section near Charleston, W. Va ........................ 85

Characteristic horizons......................................... 86

The Pittsburgh Coal Ores........................................ 86

The Little Pittsburgh Coal................................. 86

The Pittsburgh Limestones.................................. 87

The Conuellsville Sandstone.............................. 87

The Little Clarksburg Coal . . . .............................. 88

The Clarkshurg Limestone . . . . . . . . . . . . . . . . . . . . . . . . . . . 88

The Morgantown Sandstone............................. 88

The Elk Lick Coal ....................................... 89

The Elk Lick Limestone .................................... 90

The Crinoidal, Green Fossiliferous, or Ames Limestone . ............ 90

The Crinoidal Coal..................................... 91

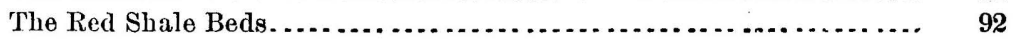

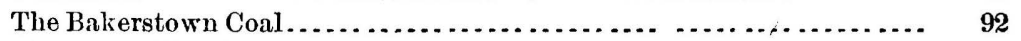

The Cambridge Limestones................................ 93

The Masontown Coal ..................................... 94

The Irondale Limestone and Ore ........................... 95

The Mahoning Sandstone ................................. 95

The Mahoning Coal ........................................... 96

The Mahoning Limestone.... . . . . . . . . . . . . . . . . . . . . . .

The Upper and Middle Cannelton Coals...................... 97

The Kanawha Black Flint................................. 98

Cirar. V. The Iower Coal Measures, or Alleghany River Series . . . . . . . . . . . 99

Thickness, character, and extent.............................. 99

Section at Blossburg, Tioga Co., Pa....................... 102

Section at Fall Brook, Tioga Co., Pa . . . . . . .............. 103

Section at Karthaus, Clearfield Co., Pa ..................... 103

Section in Horton Township, Elk Co., Pa ..................... 104

Section at Brockwayville, Jefferson Co., Pa.................. 104

Section in Clarion Co., Pa................................. 105

Section at Miller's Eddy, Clarion Co., Pa ................... 105

Section at East Brady, Clarion Co., Pa .................... 106

Section near New Bethlebem, Clarion Co., Pa................ 106

Section in Brady Township, Butler Co., Pa ................... 107

Section at Ore Hill Furnace, Armstrong Co., Pa............... 107

Section at Centerville, Armstrong Co., Pa..................... 108 
Cinar. V. The Lower Coal Measures, or Alleghany River Series-Continued. Section at Putneyville, Armstrong Co., Pa..................... 108 Section in vicinity of Kittanningr, Pa........................... 109 Section 5 miles below Kittanning, Pa ............................ 109 Section at Logansport, Armstrong Co., Pa....................... 110 Section at Freeport, Armstrong Co., P'a ........................ 111 Section near mouth of Beaver River........................... 112

Section under Sewickley, Allegbeny Co., Pa.................. 112

Section nnder Washington, $\mathrm{Pa}$............................... 113

Section near Carpenter's Station, Westmoreland Co., Pa........... 113

Section uuder Murraysville, Westmoreland (o., Pa............... 114

Seetion on Beaver Run, Westmoreland Co., Pa.................. 114

Section near Richmond, Indiana Co., Pa....................... 115

Section near Lockport and Bolivar, Indiana Co., Pa............... 115

Sectiou near Laughlinton, Westmoreland Co., Pa ............... 116

Section on Cucumber Run, Stewart Township, Fayetto Co., Pa...... 116

Section muler Newburg, Preston Co., W. Va ................... 117

Soction near Johnstown, Cambria Co., Pa.................... 118

Section at Conemangh, near Johnstown, Cambria Co., Pa .......... 119

Section in Jackson Township, Cambria Co., Pa .................. 119

Section on Ben's Creek, Cambria Co., Pa....................... 120

Section at Stoyestown, Somerset Co., Pa...................... 121

Section at P'inkerton Point, Somerset Co., Pa ................... 121

Section at Cresson, Cambria Co., Pa........................ 122

Section at Bennington, Blair Co., Pa......................... 122

Section at Clearfield, Clenrfield Co., Pa....................... 123

Section near Morrisdale, Clearfield Co., Pa..................... 123

Section at Sterling mines, near IIontzdale, Clearfield Co., Pa....... 124

Section on Shoup's Run, Broad 'Top Basin, Huntingdon Co., Pa...... 125

Section in East Broad Top Basin, Huntingdon Co., Pa............. 125

Section in Broad Top Basin, Beclford Co., Pa.................... 126

Section at Piedmont, Mineral Co., W. Va......................... 126

Section at Maple Swan! water tank, W. Va. Central Railroad......... 127

Section near 'Thomas, Tuckor Co., W. Va....................... 127

Section near Moatsville, Barbour Co., W. Va................... 128

Section at Valley Falls, Taylor Co., W. Va...................... 128

Section near Nuzum's Mills, Marion Co., W. Va.................. 129

Section under Clarkshurg, Harrison Co., W. Va ................... 129

Section under Parkersburg, W. Va............................ 130

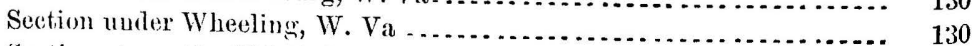

Section at mouth of Little Beaver, on the Ohio-Peunsylvauia line...... 130

Section near Sprucevale, Colmmbiana Co., Ohio................. 131

Section botween New Lisbon and Leetonia, Ohio . . . . . . . . . . . . ... 132

Section at hanesville, Mnskingum Co., Ohio.....................

Section in vieinity of Shawnee and MeCuneville, Perry Co., Ohio ....

Soction in Ilocking Valley, near Buchtel, Ohio ................... 133

Section on Mecker's Run, near Nelsonville, $A$ thens Co., Ohio......... 134

Section in Panther IIill, Mt. Vernon Furnace, Scioto Co., Ohio....... 134

Section at Ironton, Lawrence Co., Ohio....................... 135

Section in southern Ohio, above Ironton .......................

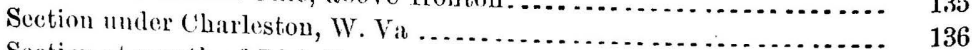

Sectiou at month of Liek Run, 2 miles above Charleston, W. Va...... 137

Section at Dickinson Salt Works, Kanawha (\%., W. Va............ 138

Section near Brownstown, 3 miles sonth from Malden, W. Va........ 139

Section at mouth of Armstrong Creek, on the Big Kanawha River.... 140 
Char. V. The Lower Coal Measnres, or Alleghany River Series-Continued. Section at Guyandotte Mountain, Raleigh Co., W. Va............. Section near Oceana, Wyoming Co., W. Va........................ Section at mouth of Blaine Creek, Lawrence Co., Ky ............ Section near Old Peach Orchard, Ky........................ Section at Warfield, Ky., and on Tug Fork of Big Sandy River... Section on Tug Fork of Big Sandy River, Logan Co., W. Va....... Characteristic horizons

The Upper Freeport Coal ........................................... Section at McCóy Shaft, near Gallitzin, Cambria Co., Pa........... Section near old Portage Railroad tunnel, at Gallitzin, Pa........ Section at Mt. Equity mine, Bedford Co., Pa..................... Section at Posten's bank, near Masontown, Preston Co., W. Va... Section at Hartley's bank, near Masontown, W. Va Section at Wilson's mine, Roaring Creek, Randolnh Co, W. Va Section on Stone Coal Run, Upshur Co., W. Va .................. Section on the Buckhannon River, Upshur Co., W. Va............ Section at Lloyd Wamsley's bank, Upshur Co., W: Va ........... Section at Bryan's bank, Upshur Co., W. Va.................... Section at Current's farm, Upshnr Co., W. Va .................... Section near Hackẹ's Valley post-office, Webster Co., W. Va..... Section on the Little Kahawha River, Webster Co., W. Va ........ Section on the Holly River, Webster Co., W. Va................ Section at Powell Mountain, Nicholas Co., W. Va................ Section on Stroud Creek, Nicholas Co., W. Va.................. Sections on Mumble-the-Peg Creek, Nicholas Co., W. Va........... Sections on the Guyandotte River, Cabell Co., W. Va ............. Sections on Cove Creek, Wayne Co., W. Va..................... Section on Twelve-pole Creek, Wayne Co., W. Va................. Section on Little Laurel Creek, Wayne Co., W. Va............... Section on Saw-pit branch of Cove Creek, Wayne Co., W. Va..... Section in Sugar Camp Hollow, Wayne Co., W. Va ................. Section ou Trough Creek, Wayne Co., W. Va..................... Section at Greene Porter's, Twelve-pole Creek, Wayne Co., W. Va. Section near Kenova, W. Va

Section in Ritchie Co., W. Va. . . . . . . . . . . . . . . . . . . . . . . . .

The Upper Freeport Limestone................................

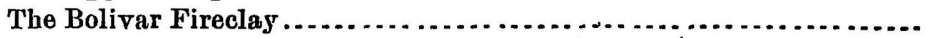

The Upper Freeport Sandstone .................................

The Middle Freeport Coal . . . . . . . . . . . . . . . . . . . . . $\ldots \ldots \ldots \ldots \ldots \ldots$

The Lower Freeport Coal . . . . . . . . . . . . . . . . . . . . . . . . . . . . . . . . . .

Section near Philippi, Barbonr Co., W. Va .....................

Section of bed at Coalburg, Kanawha Co., W. Va...............

Section at Winifrede, Kanawha Co., W. Va .....................

Section at mouth of Blaine Creek, Lawrence Co., Ky .............

The Lower Freeport Limestone. . . . . . . . . . . . . . . . . . . . . . . . . . . . . .

The Lower Freeport Sandstone.................................. 163

The Upper Kittanning Coal . . . . . . . . . . . . . . . . . . . . . . . . . . . . . . 164

The Johnstown (Cement) Limestone............................. 165

The Middle Kittanning Coal. .................................... 166

Section at Newburg, Preston Co., W. Va..................... 167

Section in Hocking Valley, Ohio.............................. 168

Section at New Straitsville, Perry Co., Ohio ................... 168

The Lower Kittanning Coal. ...................................... 169

Section at Newburg, Preston Co., W. Va...................... 170 
Chap. V. The Lower Coal Measures, or Alleghany River Series-Continucd.

The Kittanning Fire-clay ............................... 171

The Kittanning Sandstone.................................. 172

The Buhrstone Iron Ore.................................. 172

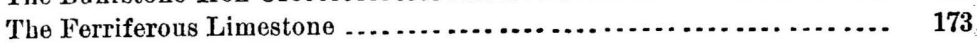

The Clarion Coal............................................... 175

Section near Eagle, Fayette Co., W. Va ................. 176

The Eagle Limestone ..................................... 177

The Brookville Coal...................................... 178

Cnap. VI. The Pottsville Conglomerate Series........................ 179

Thickness, character, and extent................................. 179

Section in Fox Township, Elk Co., Pa.................... 188

Section near Clearfield, Pa............................. 182

Section at Brookville, Jefferson Co., Pa.................... 183

Section at Patton Station, Red Bank Township, Clarion Co., Pa. 183

Section at Kellersburg, Armstrong Co., Pa .................. 184

Section under Pittsburgh, Pa............................ 184

Section under Murraysville, Pa ............................ 184

Sention under Washington, Pa......................... 185

Section in the Broad Top Basin, Huntingdon Co., Pa........... 185

Section near Wellersburg, Somerset Co., Pa................ 186

Section near Piedmont, Mineral Co., W. Va .................. 186

Section on Black Fork of Cheat River, Tucker Co., W. Va....... 187

Section near Rowlesburgh, Preston Co., W. Va.............. 188

Section near mouth of Sandy Creek, Preston Co., W. Va........ 183

Section on Booth's Creek, Taylor Co., W. Va.................. 189

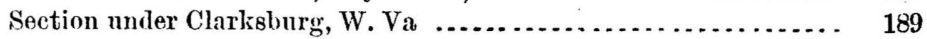

Section near Farmington, W. Va ........................ 189

Section under Wellsburg, W. Va.......................... 190

Section in Mercer Co., Pa ................................. 190

Section near Quakertown, Mahoning Co., Ohio ................ 191

Section in Holmes Co., Ohio .............................. 191

Section in Washiugton Co., Ohio ........................... 192

Section nuder Parkersburg, W. Va........................ 192

Section near Burning Springs, Wirt Co., W. Va ............... 192

Section at Jackson Furnace, Jackson Co., Ohio ............... 193

Section at Hanging Rock, Scioto Co., Ohio ..................... 193

Section on Jig Sandy River, at mouth of Blaine Creck .......... 194

Section under Charleston, Kanawha Co., W. Va . . ............. 195

Section at Burning Spring, Kanawha Co., W. Va ............... 196

Section near Nuttalluurg, Fayette Co., W. Va ............... 167

Section on Crano Croek, Mercer Co., W. Va.................... 198

Characteristic horizons........................................ 199

The Homewood Sindstone................................... 199

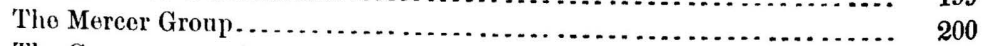

The Connoquenessing Sandstones................................ 201

The New River Coal Group .................................... 20.2

Section on Crane Creok, near Pocahontas, Va................ 203

Section at head of South Elk Horn Creek, McDowell Co., W. Va.. 203

Section on East Branch of Simmon's Creek, Mercer Co., W. Va.... 203

Section on Walker tract, Flipping Creek, Mercer Co., W. Va..... 204

Section on Pinnacle Fork of Guyandotte River, Mercer Co., W. Va 204

The Sharon Conglomerate .................................. 204

The Lower Carboniferous Beds ................................ 205 


\section{ILLUSTRATIONS.}

Prate I. Map showing the general distribution of the Carboniferous in Pennsylvania, West Virginia, and Ohio ....................... Frontispiece.

II. Sections across the Appalachian Coal Fields. Figs. 1 and $2 \ldots \ldots \ldots$... 16

III. Sections across the Appalachian Coal Fields, from Ravenua, Ohio, to the Alleghany mountains. .............................. 18

IV. Permo-Carboniferous, Cameron, W. Va ....................... 20

V. Upper Coal Measures, capped with Permo-Carboniferous beds, Wheeling, W. Va.

VI. Upper Coal Measures and Permo-Carboniferous, Powhatan, Ohio...

VII. Upper Coal Measures at Point Pleasant, W. Va ...................

VIII. The Pittsburgh coal outcrop near Connellsville, Pa ...............

IX. Lower Coal Measures, Coalburg, Kanawha River, W. Va...........

$\mathrm{X}$. The Pottsville conglomerate topography in Blackwater Canyon....

XI. The Pottsville conglomerate cliffs and débris, New River, West Virginia

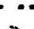

FIG. 1. Section on Dunkard Creek, Greene Co., Pa

2. Section on Colrin's Run, Greene Co. Pa

3. Section in Aleppo Township, Greene Co., Pa ...............................

4. Section at Board Tree, Marshall Co., W. Va . ....................

5. Section at Bellton, Marshall Co., W. Va . . . . . . . . . . . . . . . . . .

6. Section at New Martinsville, Wetzel Co., W. Va ..................

7. Section at Baresville, Monroe Co., Ohio ........................

8. Section in Liberty Township, Washington Co., Ohio...............

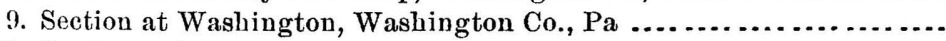

10. Section near Taylorstown, Washington Co., Pa...................

11. Section in Fayette and Westmoreland Cos., Pa ..................

12. Section at Brownsville, Fayette Co., Pa.........................

13. Section at West Brownsville, Washington Co., $\mathrm{Pa} \ldots \ldots . . . . . . . .$.

14. Section at Rice's Landing, Greene Co., Pa . . . . . . . . . . . . . . . . . . .

15. Section on Robiuson's Run, Monongalia Co., W. Va ................

16. Section on Scott's Run, Monongalia Co., W. Va....................

17. Section on Buffalo Creek, Marion Co., W. Va ....................

18. Section at Clarksburg, Harrison Co., W. Va ..... ................

19. Section on Chapline Hill, Wheeling, W. Va ......................

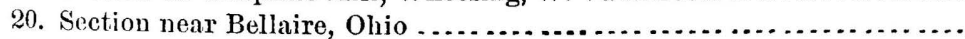

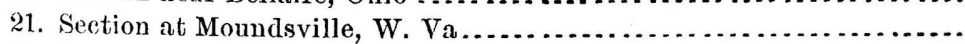

22. Section on Pipe Creek, Belmont Co., Ohio........................

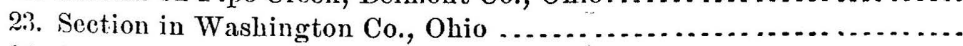

24. Section at Burning Springs, Wirt Co., W. Va....................

25. Section on Leading Creek, Gilmer Co., W. Va .....................

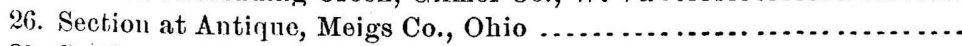

27. Section at Hartford City, Mason Co., W. Va. .....................

28. Section at Arbuckle, Mason Co., W. Va

Page. 
Frg. 29. Section at mouth of Big IIurricane Creck, Putnam Co., W. Va......

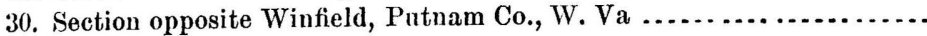

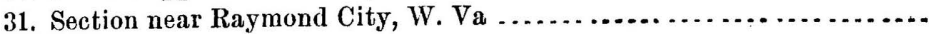

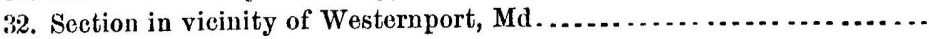

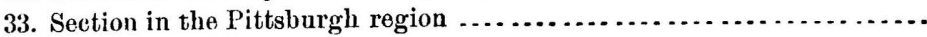

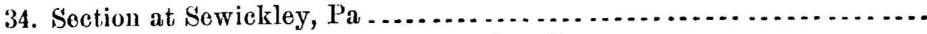

35. Section on Dnnbar Creek, Fayette Co., Pa ......................

36. Section at Ligonier, Westmoreland Co., Pa.....................

37. Section in vicinity of Berlin, Somerset Co., Pa ...................

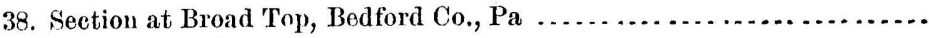

39. Section opposite Steubenville, Ohio .........................

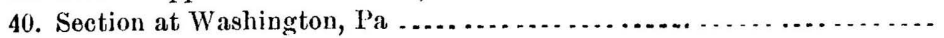

41. Section near Canuonsburg, Washington Co., Pa .................

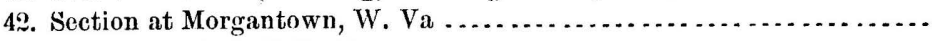

43. Section at Little Falls, Monongalia Co., IV. Va ..................

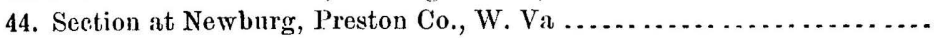

45. Section at Fairfax Krob, 'Tucker Co., W. Va..........................

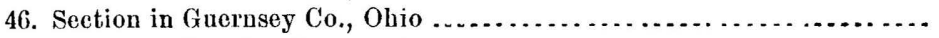

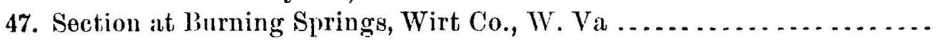

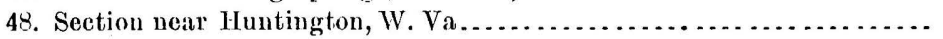

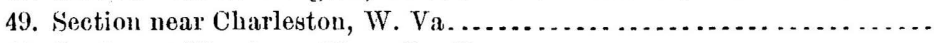

50. Section at Blossburg, 'Tioga Co., Pa .........................

51. Section at Fall Brook, Tioga Co., Pa ...........................

52. Section at Karthaus, Clearfield Co., Pa.........................

53. Section in Horton Township, Elk Co., Pa ......................

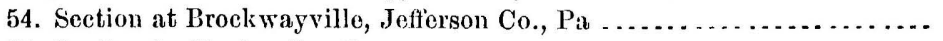

55. Section in Clarion Co., $\mathrm{Pa}$

56. Section at Miller's Eddy, Clarion Co., Pa......................

57. Section at East Brady, Clarion Co., Pa........................

58. Section near New Bethlehem, Clarion Co., Pa....................

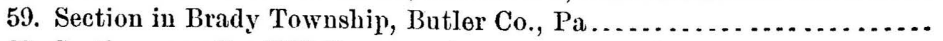

60. Section near Ore Hill Furnace, Armstrong Co., Pa................

61. Section at Centerville, Armstrong Co., Pa......................

62. Section at Putneyville, Armstrong Co., Pa .......................

63. Sectioli near Kittamning, $\mathrm{Pa}$

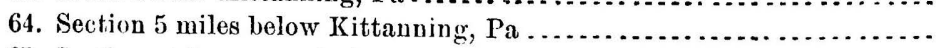

65. Section at Logansport, Armstrong Co., Pa . . . . . . . . . . . . . . . .

66. Section at Freeport, Pa:

67. Section near mouth of Beaver River,

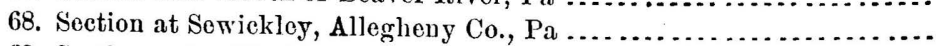

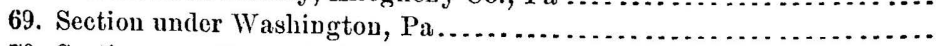

70. Section near Carpenter's Station, Westmoreland Co., Pa . . . . . . . . .

71. Section under Murraysville, Westmoreland Co., Pa .................

72. Section on Beaver Run, Westmoreland Co., $\mathrm{Pa} \ldots \ldots \ldots \ldots . . . . . . . . . .$.

73. Section near Richmond, Indiana Co., Pa ..........................

74. Section near Lockport and Bolivar, Indiana Co., Pa ...............

75. Section on Laurel Run, near Laughlintown, Westmoreland Co., Pa ..

76. Section on Cuenmber Run, Stewart Township, Fayette Co., Pa.....

77. Section at Newburg, Preston Co., W. Va .......................

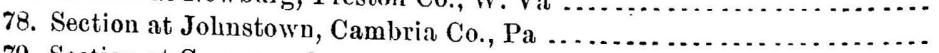

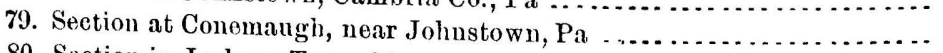

80. Section in Jackson Township, Cimbria Co., Pa..................

81. Section on Ben's Creek, Cambria Co., Pa..........................

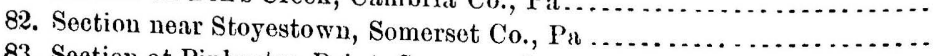

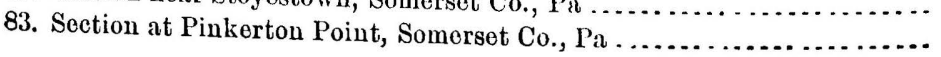


Fig. 84. Section at Cresson, $\mathrm{Pa} \ldots \ldots \ldots \ldots \ldots$.........

85. Section at Bennington, Blair Co., Pa....................... 122

86. Section at Clearfield, Clearfield Co., Pa .................... 123

87. Section near Morrisdale, Clearfield Co., Pa .................... 123

88. Section at Sterling mines, near Houtzdale, Clearfield Co., Pa....... 124

89. Section on Shoup's Run, Broad Top Basin, Huntingdon Co., Pa..... 125

90. Section East Broad Top Basin, Huntingdon Co., Pa............. 125

91. Section in Broad Top Basin, Bedford Co., Pa .................. 126

92. Section at Piedmont, Mineral Co., W. Va..................... 126

93. Section on North Potomac, at Maple Swamp Water Tank, West Virginia Central Räilroad .................................... 127

94. Section near Thomas, Tucker Co., W. Va.................... 127

95. Section near Moatsville, Barbour Co., W. Va ................. 128

96. Section at Valley Falls, Taylor Co., W. Va.................... 128

97. Section near Nuzum's Mills, Marion Co., W. Va................ 129

98. Section under Clarksburg, W. Va .......................... 129

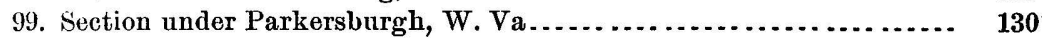

100. Section under Wheeling, W. Va ........................... 130

101. Section at mouth of Little Beaver, on the Ohio-Pennsylvania line..... 130

102. Section near Sprucevale, Columbiana Co., Ohio ................. 131

103. Section between New Lisbon and Leetonia, Ohio . ............... 132

104. Section at Zanesville, Muskingum Co., Ohio...................... 132

105. Section in vicinity of Shawnee and McCuneville, Perry Co., Ohio... 133

106. Section in Hocking Valley, near Buchtel, Ohio ................. 133

107. Section on Meeker's Run, near Nelsonville, Athens Co., Ohio........ 134

108. Section in Panther Hill, Mt. Vernon Furnace, Scioto Co., Ohio...... 134

109. Section at Ironton, Ohio ................................... 135

110. Section in southern Ohio, above Ironton..................... 135

111. Section under Charleston, W. Va .......................... 136

112. Section at mouth of Lick Run, 2 miles above Charleston, W. Va .... 137

113. Section at Dickinson salt works, Kanawha Co., W. Va........... 138

114. Section near Brownstown, 3 miles sonth from Malden . ............. 139

115. Section at mouth of Armstrong Creek, on the Big Kanawha River... 140

116. Section at Guyandotte Mountain, Raleigh Co., W. Va............. 142

117. Section near Oceana, Wyoming Co., W. Va .................. 143

118. Section at mouth of Blaine Creek, 20 miles above mouth of Big Sandy River, Lawrence Co., Ky........................... 144

119. Section near Peach Orchard, Lawrence Co., Ky ................. 145

120. Section near Warfield, Ky., on Tug Fork of Big Sandy Rivor . ...... 146

121. Section on 'Tug Fork of Big Sandy River, near month of Knox Creek, southern edge of Logan Co., W. Va ....................... 147

122. Section in Fox Township, Elk Co., Pa...................... 182

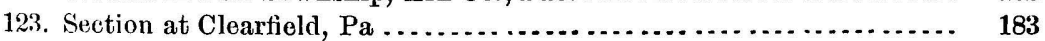

124. Section at Brookville, Jefferson Co., Pa ......................... 183

125. Section at Patton Station, Red Bank Township, Clarion Co., Pa $\quad . . \quad 183$

126. Section at Kellersburgh, Armstrong Co., Pa .................... 184

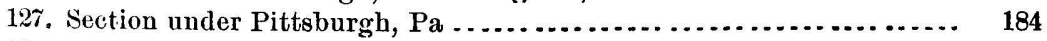

128. Section under Murraysville, Pa............................. 185

129. Section under Washington, Pa . ............................. 185

130. Section in the Broad Top Basin, Huntingdon Co., Pa . . . . . . . . . . 185

131. Section on Gladden's Run, near Wellersburg, Somerset Co., Pa..... 186

132. Section near Piedmont, Mineral Co., W. Va..................... 186

133. Section on Black Fork of Cheat River, Tucker Co., W. Va . . . . . .... 187

134. Section along the Baltimore and Ohio Railroad, Cheat River grade, 4 miles west from Rowlesburgh, Preston Co., W. Va .............. 



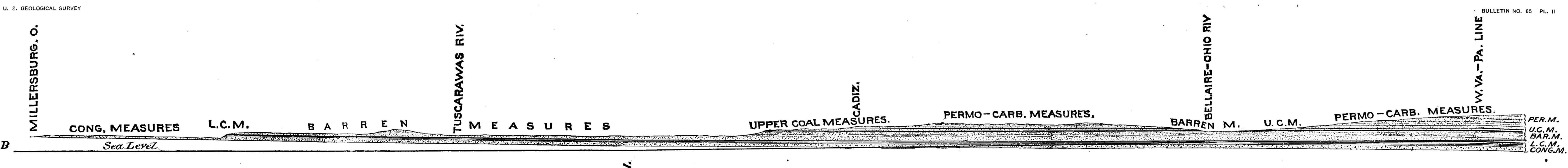
PERMO-OARB⿱㇒⿴囗十

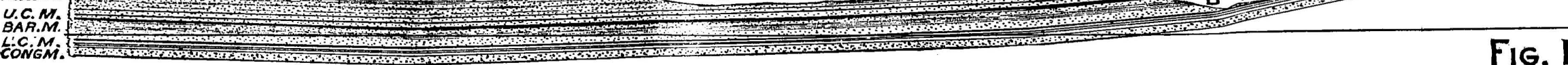
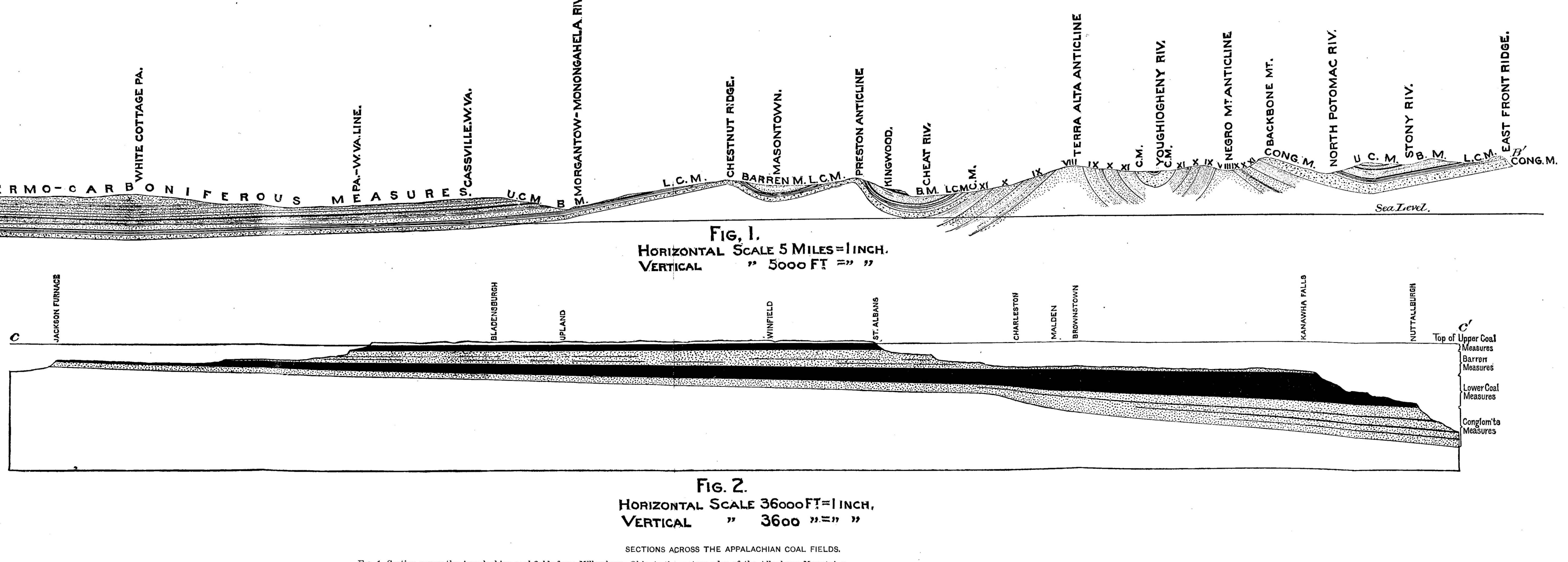

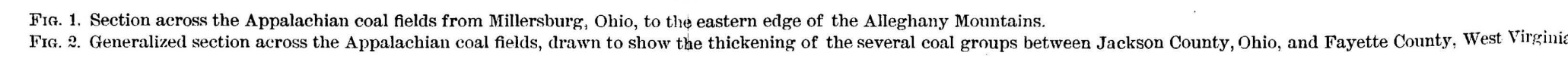





\section{STRATIGRAPHY OF THE BITUMINOUS COAL FIELD IN PENNSYLVANIA, 0HI0, AND WEST VIRGINIA.}

BY I. C. WhITE.

CH A P TER I.

AREA, STRUCTURE, AND CLASSIFICATION,

The Appalachian Basin contains the largest continuous coal field of any Carboniferous area. Beginning near the northern line of Pennsyl. vania, latitude $42^{\circ}$, longitude $77^{\circ}$, it extends southwestward through West Virginia, southeastern Ohio, eastern Kentucky, and central Tennessee, ending in western Alabama, latitude $33^{\circ}$, longitude $88^{\circ}, 900$ miles from its northern terminus.

The shape of the field has been compared to that of a rude canoe, tha pointed ends being in Pennsylvania and Alabama, respectively, while the broadest portion lies in southern West Virginia and Ohio.

$A s$ is well known, the general structure of the field is that of a great trough or basin, the line of greatest depth leaving Penusylvania near its southwest corner, and passing down through West Virginia rudely parallel to the Ohio River, to enter Kentucky 10 miles above the mouth of the Big Sandy River. This general trough or geo-syncline is itself traversed, especially in its northeastern portion, by a series of flexures, which, although so gentle along the region west of the center of the field as to be recognizable with difficulty, yet eastward thereof they increase in amplitude until the great folds of the Alleghany Mountains become a part of the system.

The map sections shown on Pls. X and XI, crossing the Appalachian field nearly normal to the strike, will give the reader a good idea of the, structure of the northern half of this field at the localities indicated on the map (Pl. I), and they also show how the folds which are so prominent at the northeast gradually die out toward the southwest, so that in the region of the Great Kanawha River they almost disappear. This flattening out of the flexures in southern West Virginia has been ascribed by Professors Fontaine and Stevenson to the development of the great system of faults along the southeasteru margin of the coal field in the edge of Virginia, which relieved the tension on the rocks over Bull, 65-22 
the adjoining portion of the $\Lambda$ ppalachian field and thus prevented their folding as in Pennsylvania and northern West Virginia. These anticlinal and syncliual folds so well developed at the north are nearly parallel to the Alleghany Mountains, but as they begin to die away in central West Virginia a large anticline (the Volcano) runs nearly north and south diagonally across the general strike of the beds.

There are probably other folds in the southwestern part of West Vir. ginia, which, like the Volcano anticline, run contrary to the usual direction, but they have not been traced out with sufficient care to warrant description.

The distribution of the different geological groups on the accompanying mal will serve to show the general position and direction of the principal anticlines, but the topographic base of the map is so inaccu. rate that it was thought best not to attempt to put in the anticlinal lines of the region described till the Survey should have completed the regular topographical map.

In this connection it should be stated that this map is not presented with any claims for accuracy in detail, but simply to show the general distribution of the Carboniferous system.

The portion of the Appalachian region herein described includes only the bitumincus coal fields of Pennsylvania, Ohio, and West Virginia.

The Pennsylvania and Virginia geologists, led by the two illustrious Rogers brothers, long ago discovered that the main coal-bearing portion of the Carboniferous system could be naturally subdivided into five series. This generalization was founded upon a careful study of the rocks over a wide area, and the subseguent work of other geologists has fully established its general truthfulness to nature as well as its great usefulness in stratigraphic geology.

The more detailed and minute studies of recent years, rendered possible by vast mining developments, have only modified the Rogers classification, and hence it has become so thoroughly ingrafted into geological nomenclature and so familiar to the minds of practical coal operators that it would be very unwise to make any radical changes in it. It is true that in minor details the original nomenclature for some of these series was misleading, but this does not materially affect the grand truths expressed in the general framework of the classification, and hence it has been deemed best to modify and supplement this timehonored work, rather than to destroy it and cast it away, as has recently been suggested by some geologists.

The classification adopted in this report attempts to preserve what ever of the old nomenclature has been found useful and helpful to. geologists, while at the same time such new features are introduced as: seem necessary from our wider and more intimate knowledge of these rocks.

The entire Carboniferous system of the Appalachian region subdivides naturally into three grand divisions founded upou conditions of accu- 

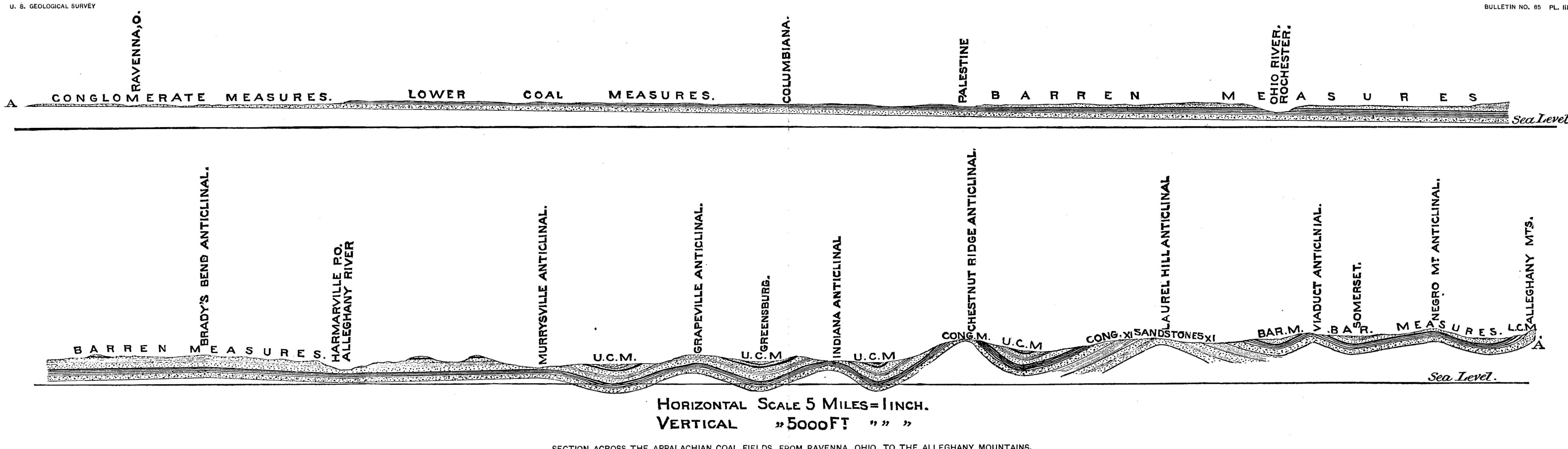

SECTION ACROSS THE APPALACHIAN COAL FIELDS, From rAVENNA, OHIO, TO THE aLLEGHANY MOUNTAING. 

mulation, and these in turn split up into eight minor series, as exhibited in the following scheme:

\begin{tabular}{|c|c|c|}
\hline \multirow{8}{*}{$\begin{array}{l}\text { CARHONIFEROUS } \\
\text { SYSTEM } . . . . . . .\end{array}$} & Divisions. & Series. \\
\hline & \multirow{2}{*}{$\begin{array}{l}\text { Upper: fresh and } \\
\text { brackish water } \\
\text { deposits. }\end{array}$} & Permo-Carboniferous, No. XVI, Dunkard Creek Series. \\
\hline & & Upper Coal Measures, No. XV, Monongahela River Series. \\
\hline & \multirow{3}{*}{$\begin{array}{l}\text { Middle: shore rle- } \\
\text { posits, with in- } \\
\text { cursions of the } \\
\text { sea. }\end{array}$} & Barren Measures, No. XIV, Elk River Series. $\mid \frac{\text { Upper half. }}{\overline{\text { Lower half. }}}$ \\
\hline & & I.ower Coal Measures, No. XIII, Allegheny River Series. \\
\hline & & $\begin{array}{l}\text { Pottsville Conglomerate Measures, "Great," "Seral," No. XII } \\
\text { Conglomerate, etc. }\end{array}$ \\
\hline & \multirow[t]{2}{*}{$\begin{array}{l}\text { Lower: marine } \\
\text { deposits. }\end{array}$} & $\begin{array}{l}\text { Mauch Chunk Red Shale, Umbral Red Shale. } \\
\text { Mountain Limestone, Umbral Limestone, Green- }\{\text { No. XI. } \\
\text { brier, etc. }\end{array}$ \\
\hline & & Pocono Sandstono, Vespertine, No. X, "Big Injun" oil sand, etc. \\
\hline
\end{tabular}

As will be seen from the foregoing diagram, the line between the Middle and Upper Carboniferous deposits passes directly through the center of the Elk River series. This is due to the fact that marine conditions ceased, never to return, with the deposition of the Crinoidal limestone and its associated beds, midway in the Barren Measures, thus separating them into two divisions which are of almost equal thickness, the lower one abounding in marine life, while the upper has nothing but fresh or brackish water forms. The change in this respect is great enough to warrant the separation of the Barrens into two series, but as the lithological differences at the line of separation are very meager, it is deemed best to keep these rocks a unit as in the Rogers nomenclature.

This report deals only with the Middle and Upper Carboniferous of the above table, and the five series into which they are subdivided will now be described in detail, beginning with the highest.

The discussion of many interesting questions connected with Carboniferous geology is necessarily postponed until the rest or southern half of the Appalachian coal field has been carefully studied as a whole. 
C H A P T E R I .

\section{THE PERMO-CARBONIFEROUS OR DUNKARD CREEK SERIES.}

THICKNESS, CHARACTER, AND EXTENT.

The rocks of this series (Upper Barren Measures, No. XVI) begin with the roof shales of the Waynesburg coal and extend upward to the topmost beds of the Appalachiau region.

How many feet of deposits erosion has removed above the highest remaining beds we can only conjecture. However, if the soft and easily yielding character of the rocks which have escaped disintegration can be taken as a criterion for those that have wasted away, the thickness of the latter must be reckoued by the thousand and probably by the 10,000 feet.

Several independent measurements from the highest accessible sum. mits foot up a little more than 1,150 feet for the thickness of the series and it is certain that no other localities could exceed this by more than 100 feet.

The uppermost beds are found at the headwaters of Dunkard Creek, a lirge stream which heads near the West Virginia-Pennsylvania line, on the eastern slope of the watershed separating the Ohio and Monongaheli River drainage system, and flowing eastward puts into the Monongahela two miles above Greensboro, Greene County, Pennsyl. vania, and fon miles north from the West Virginia line. This stream flows over Permo-Carboniferous rocks from its source to the point at which it leaves the West Virginia line at Mount Morris, Pennsylvania, a distance of more than thirty miles, furuishing very fine exposures of these rocks along its banks and bluffs; hence tho geographical name (Dunkard Creek) which I have given the series.

These deposits oceupy a rather limited area in the Appalachian field, being found in only two counties (Greene and Washington) of Penusyl. vania, with the exception of small isolated patches in Fayette, Westmoreland, and Allegheny. In Ohio there is a larger area of them bordering the Ohio River through the countios of Belmont, Monroe, Washingtou, Athens, Meigs, and Gallia. But it is in West Virginia thit we find the priucipal belc of these beds, for there they cover a wide 


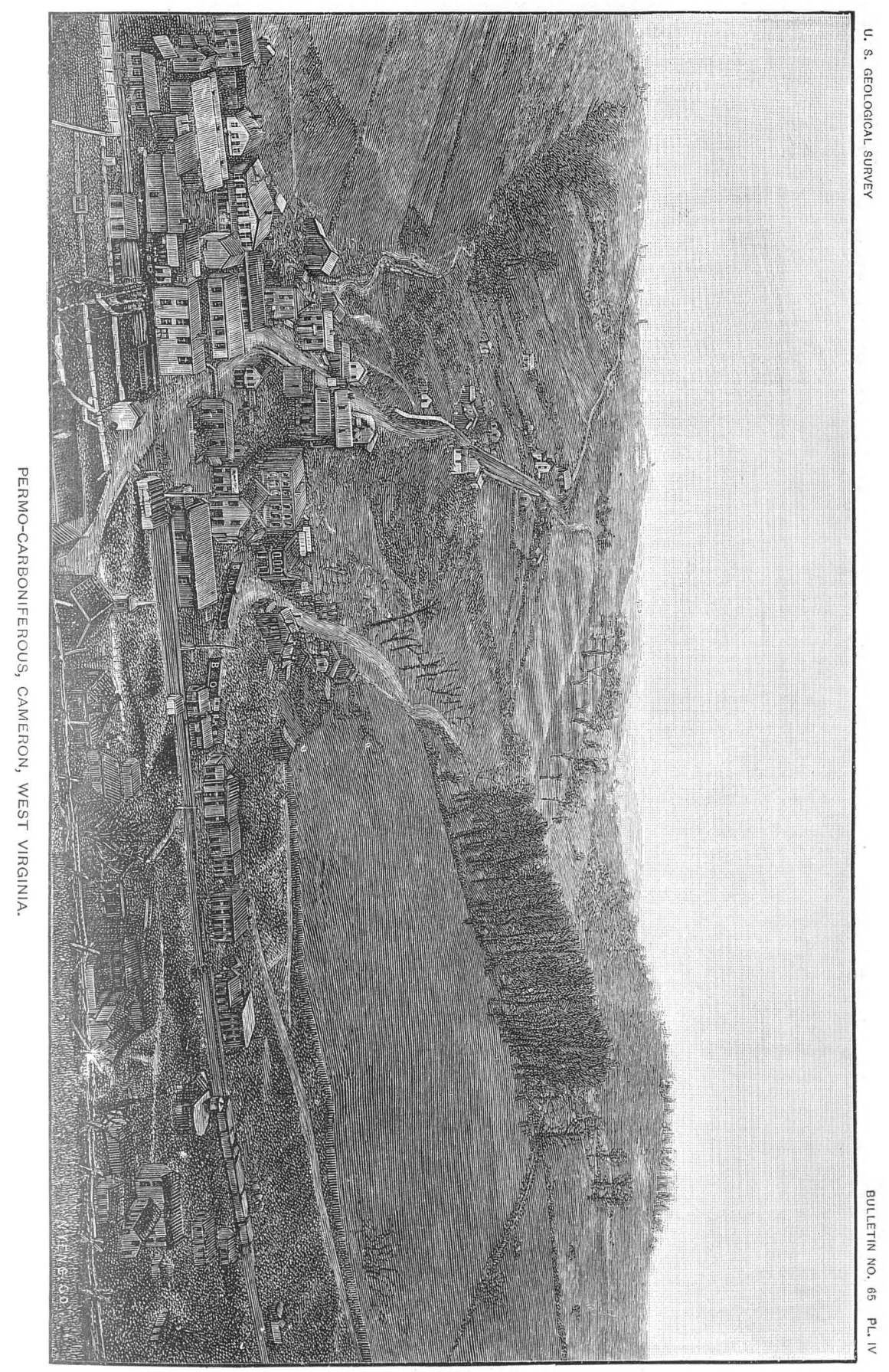



region bordering the Obio River between the Pennsylvania line at the north and the Great Kanawha River on the south, as the accompanying map shows.

The character of the rocks varies greatly in different portions of this area. At the northeastern end of the field, in Washington County, Pennsylvania, limestones seem to predominate in thickness over the gray shales, sandstones, and thin coal beds with which they are there interstratified. But sonthwestward the limestones and coals gradually disappear, so that in Jackson County, West Virginia, no regular coal beds are found, and only one limestone (the Nineveh) remains. The limestones continue in considerable number in Greene, Ohio, Marshall, and Monongalia Counties, and the northern part of Wetzel County, but southward from this line they rapidly disappear, with the single exception noted. The coal beds all die out with the disappearance of the limestones, except one (the Washington), which seems to extend beyond the Little Kanawha River before it passes out of the series.

As the limestones and thin coal beds gradually fade out to the south. west, red shale, a variety of rock almost unknown in Washington County, Penusylvania, gradually comes into the section in thin beds at first, but finally extends throughout the whole series, and forms nearly one-half its thickness, thus making a broad band of red soil from the Pennsylvania line south westward to the Great Kanawha River.

This increase in red shale beds is accompanied by an increase in the number and massiveness of the sandstone rocks, so that the topography gradually becomes greatly different from that found in Washington County, Pennsylvania. There the surface is gently rolling, the valleys broad, and the hills rounded, with no deep gorges or precipitous slopes, the abundance of limestone rendering the soil so highly fertile that the region has long been famed as one of the finest grazing and agricultural districts in the Union. But toward the south west, while the soil remains very fertile, owing to a large quantity of marly material in the red shales, yet the thickening up of the sandstone beds makes the valleys narrow and the lower portion of the hills often precipitous, the arable land being confined largely to the ridges, so that the soil is better adapted to grazing than tillage. In many cases the massive saudstones crop out along the ridges which they have protected from erosion, forming narrow " hogbacks," from which the surface falls away rapidly on each side. Another peculiarity of these beds is that the sand rocks contain no pebbles except near the base of the series, since above the Waynesburg sandstone no pebbles larger than coarse sand grains have ever been seen hy the writer in all of the 1,000 feet of deposits, except at a single locality on the Parkersburg and Staunton turnpike, along the dividing ridge between Ritchie and Gilmer Connties, West Virginia, where locally the Marietta Sandstones, 140 feet above the Wáshington coal, thicken up into a very coarse conglomerate, filled with quartz pebbles. 
The character of the rocks which compose these measures in the several regions of their area will be seen from the sections which follow.

Section on Dunkiard Creek, Greene County, Pennsyl. vania.--Fig. 1 shows the succession found along Dunkard Creek, from the head of its Pennsylvania fork in Gilmore Township, Greene County, eastward to where the stream reers northward back into Pennsylvania at Mount Morris.

Dunlard Creei, Greenc County, Pennsylvania.

[See map, L ] to L k.]

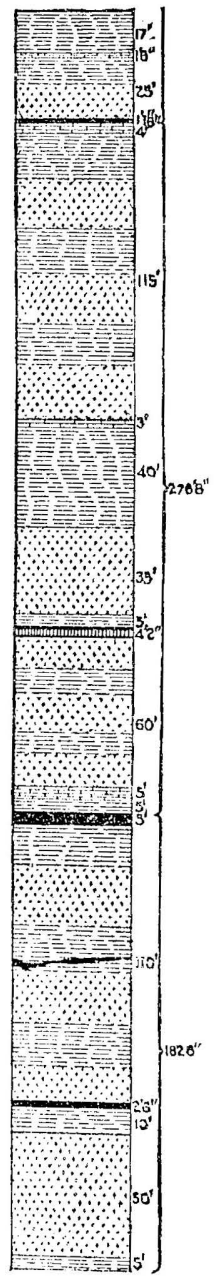

1. Concealed from top of Shough's linol.......................... 16

2. Sandsteme......................... 40

3. Shales, with limestime at hase ... 15

4. Sandstone and shates and con-

5. Shate, rext .......................... 100

6. Shilles, yray ..................... 20

7. Shate, marly ................... 2

8. Simbistonte and shale................ 35

9. Shale, red...................... 3

10. Sandistome and shale

11. Liend slitk ...................... 3

12. Shlaley and sandstone, Nineveh.. 25

13. Shales..................... 20

14. Conl, Nineveh.................. 1

15. Shates ....................... 28

17. Mald s, simedstone and concoaled. 100

18. Sandstome, massive, Fisl Creek.. 20

19. Shatres with fossil plants......... 10

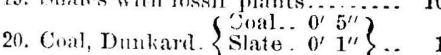

21. $\left\{\right.$ Coal.. $\left.0^{\prime} 6^{\prime \prime}\right\} \cdots$

21. Limestene

22 . Sindsteme..........................

23. Slialin som

24. Limesteme, Jollytown ............ 1

25. Shates and samdistone ............. 25

26. Coal, Jollytown.................... 1

27. Callatewers shate, fossiliferous,

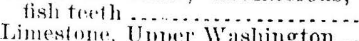

28. Limestome, Upper Washington ..

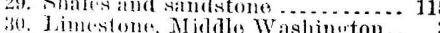

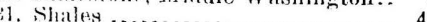

3. Simdstone...................... 35

33. Shiales ..............

34. Coal, Wash $\left\{\right.$ Conl, impure. $\left.1^{\prime} 2^{\prime \prime}\right)$

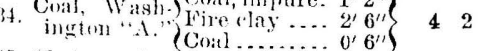

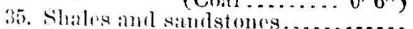

36. Limestone, Jower Washington

37. Slater.... .........

38. Coal, Washinetom, slat

39. Shales and sandetones, includiug

a coal bus near center ......... 110

40. Coal, Wayneshurg, "A "......... 2

11)

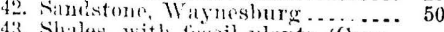

43. Shales, with fuissil plants (Cass-

44. Witymeting.......

in $\quad$ Ft in

Total 
Section on Colvin's Run, Greene County, Pennsylvania.-The lower half of this Dunkard Creek series is very finely exposed in a continuous section on Colvin's Run, a tributary of Dunkard which empties into it near Mount Morris, Greene County, Pennsylvania, and in descending this stream the following intervals, as shown in Fig. 2, were carefully measared :

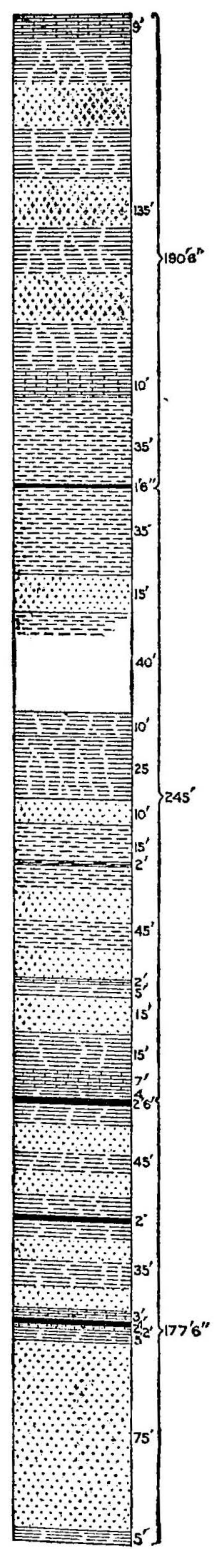

Colvin's Run, Greene County, Pennsylvania.

[See nap, L 1.]

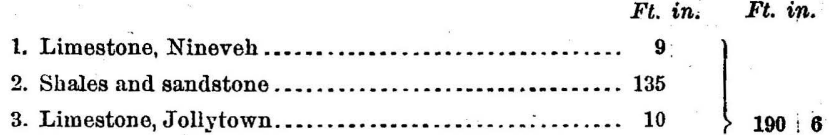

4. Sandy shales ................................ 35

5. Coal, Jollytown .............................. 16

6. Shales, sandy .................................. 35

7. Sandstone, massive............................ 15

8. Sandy shales and concealed ......................... 40

9. Red shales........................................... 10

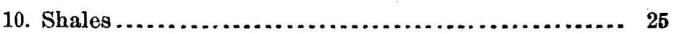

11. Sandstone ........................................... 10

12. Shales ............................................. 15

13. Coaly shales, Wishington, "A" .................. 2

14. Sandy shales and sandstone ..................... 45

15. Limestone, gray ............................... 2

16. Shales........................................ 5

17. Sandstone, massive............................. 15

18. Shales ......................................... 15

19. Limestone, Washington Lower ..................... T

20. Shale, dark .................................. 4

21. Coal, Washington .............................. 2

22. Shales and sandstone .......................... 45

23. Coal, Waynesburg, "B" ......................... 2

24. Shales and sandstone ............................ 35

25. Limestone, Colvin's Run .......................... 3

26. Shales .......................................... 1

27. Coal, Waynesburg, "A" A...................... 2

28. Limestone .................................... 2

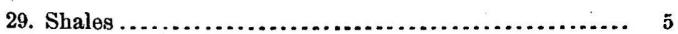

30. Sandstone, Waynesburg.............................. 75

31. Shales, with fossil plants (Cassville) ............... 5

32. Coal, Waynesburg.

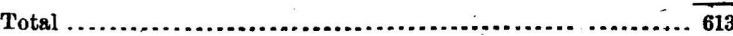

Fia. 2,-Section on Col. vin's Run, Pa. 
Section in Aleppo Township, Greene County, Pennsylvania.-Wheeling Creek rises on the western slope of the Monongabela-Ohio divide, and flowing westward enters the Ohio River at Wheeling.

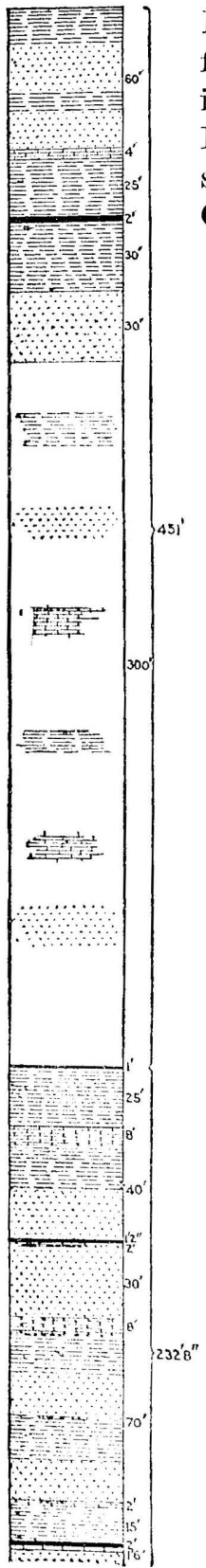
It furnishes excellent exposures of the Dunkard beds from the summit of the series to the base. The follow. ing interrals (Fig. 3) were measured along the Dunkard Fork of the creek between its source in Aleppo Town. ship, Greene Connty, Penusylvania, and the mouth of Crab Apple Creek, near the West Virginia line:

\section{Alepo Tounstip, oreche Count!y, Pennsylvania.}

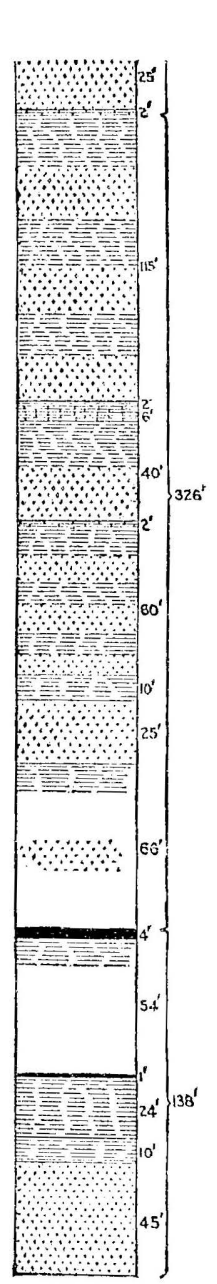

Fut. 3. - Section in Grene county, I'a.

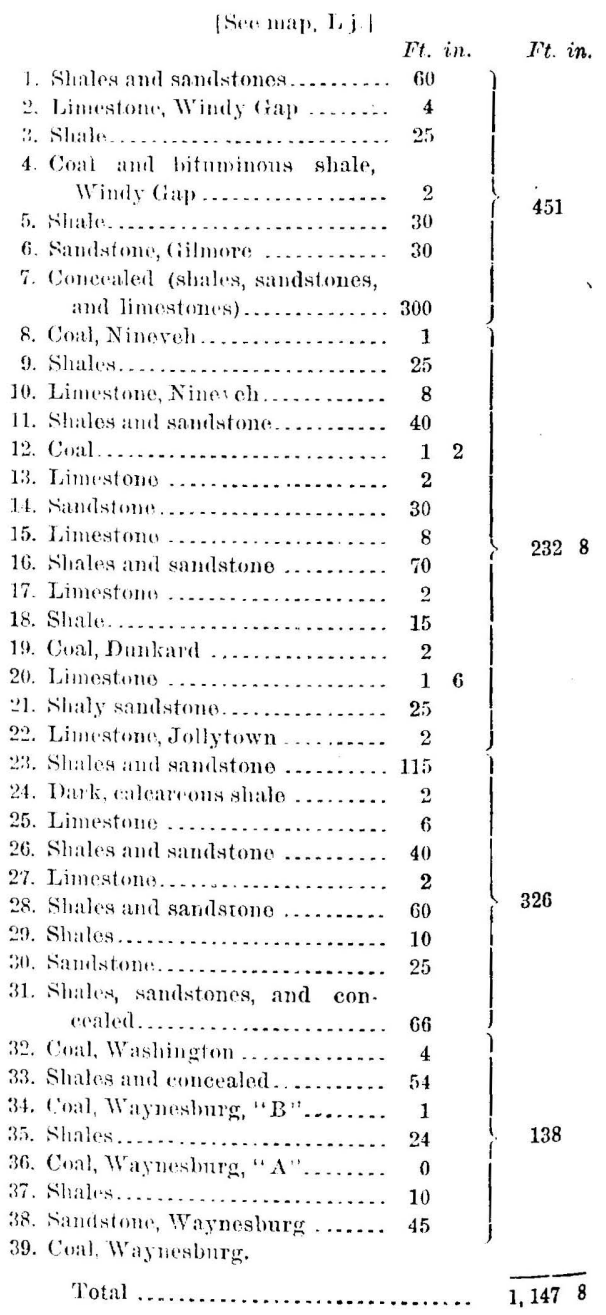


Section at Board Tree Tunnel, Marshall County, West Virginia.-At Board Tree Tuunel, on the Baltimore and Ohio Railroad, and close to \begin{tabular}{|l|l} 
the line between Wetzel and Marshall Counties, some \\
very high land occurs, while an oil well boring in the \\
valley of Fish Creek near by carries the rock meas- \\
urement down to the base of the Dunkard Creek beds.
\end{tabular}

Board Tree. Marshall County, West Virginia.

\section{$[$ Seo map, $L \mathbf{j}$.}

1. Sandstone, gray, and concealed.

2. Gray limestone, Windy Gap ....

3. Red shales and concealed ........

4. Coaly slate

5. Concealed to base of a massive sandstone......................

6. Concealed, sandstone and red shale to Board Tree Tunnel....

7. Sandy shales..................

8. Sandstone, Niveveh.............

9. Coal, Nineveh ...................

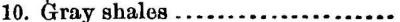

11. Sandstone, massive .............

12. Shales .......................

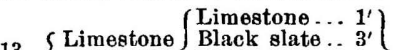

13. $\left\{\begin{array}{l}\text { Limestone } \\ \text { Nineveh... }\end{array} \begin{array}{l}\text { Black slate... } \\ \text { Limestone and } \\ \text { limy beds }\end{array}\right\}$

14. Variegated shales..............

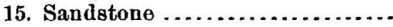

16. Sbales, limy ...................

17. Sandstone, to level of track at west portal ..................

18. Concealed shalesand sandstone.

19. Massive sandstone, Fish Creek .

20. Shales ..........................

21. Coal, Dunkard, to level of bore hole

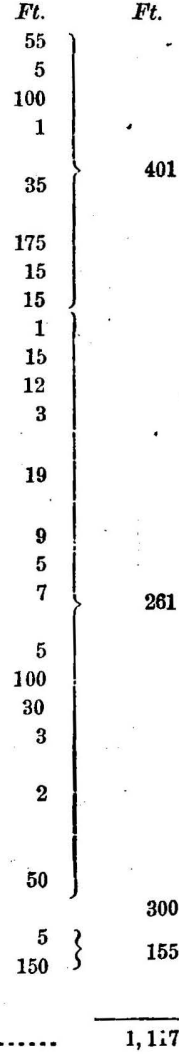

22. Interval, shales, sandstones, and limestones, with two thin coal beds ..........................

23. Shales, sandstones, and red beds.

24. Coal, Washington..............

25. Shales,limestones, and sandstone

26. Coal, Waynesburg.

Total

There is some uncertainty about the horizon of the Pittsburgh coal in the oil boring, since two large beds are reported, one at 700 feet and the other at 800 . The latter is the thicker bed, FIG. 4.-Section at Board Tree Tunnel, Mar. shall County, W. Va.

third oil sand (2,100 feet) agrees with the 
same interval 15 miles to the northeast, I have regarded the lower bed as the Pittsburgh in constructing the abore section. If, however, the coal 100 feet higher should prove to be the Pittsburgh, then

the 5-foot coal 150 feet above the bottom of the sec-
tion would probably be the Waynesburg bed, and the
Dunkard Creek series should be cut off just above it,
and thus shortened by 155 feet at this locality.
In the vicinity of Bellton, Marshall Connty, West
Virginia, 4 miles west from Board Tree Tunnel, the
exposures are very fine and the surface outcrops can
there also be combined with the record of an oil bor-
ing, which thus gives another measurement of the en-
tire series.
Section at Bellton, Marshall County, West Virginia.-
In descending from the highest summits near Bellton,
the following succession (Fig. 5) is obtained when
combined with an oil-boring record which was pub-
lished by the writer in the Annals of the Lyceum of
Natural History, New York, July, 1874:

Bellton, Marshall County, West Virginia.

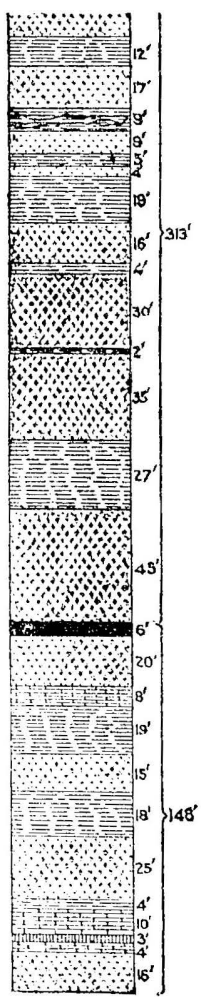

[See map, L j.]

1. Limestone, Windy Gap ......... $F^{\prime}$.

2. Sliales ..................... 30

3. Coal, Windy Gap, blossom........

4. Concealed and sandstone and shales ....................

6. Shalis and sandstone .......... 60

6. Samistone, massice, gray ....... 20

7. Rert shales and concealed ....... 75

8. Sandstone, mitssive ............ 40

9. Red shales and sandstone...... 50

11. Limestone ................ 3

11. Shales am concealea $\ldots \ldots \ldots \ldots .20$

12. Coal, Nineveh ................ 1

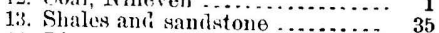

14. Limestone andshales, Ninoveh.. 10

15. Shales, sandstone and concealed. 100

16. Sandstoni................ 5

17. Shales $\ldots \ldots \ldots \ldots \ldots \ldots \ldots \ldots \ldots .10$

18. Limestono ...................... 0

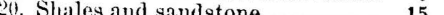

21. Red shaleg.

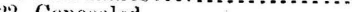

23. Concealta...................... 20

24. Shales and concenled ............

25. Coal, Dunkard $\left\{\right.$ Black slate $\left.4^{\prime \prime}\right\} \quad 13$

26. Limy shales and fire clay ...... 5

27. Shales ................... 13

28. Limestone, gray, Jollytown.....

29. Shalisond and sandistones ............

30. Coal, Joll sandstones .......... 30

31. Limestone, gray, Upper Washinston (continued from oil wall

32. Sandstone....................

33. Shale ......................

34. Sandstone......................

35. Shilo

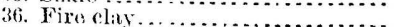

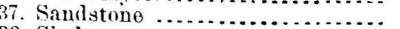

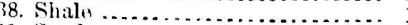

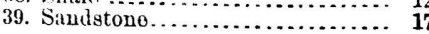

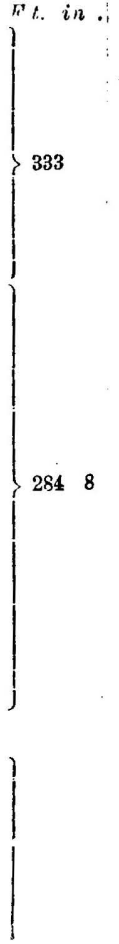

Fia. 5.--joction at Bellton, W. Va. 

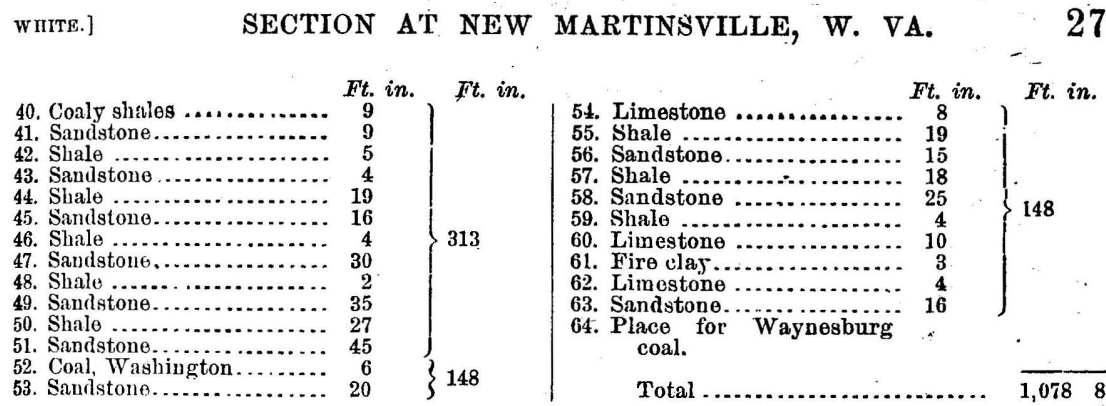

This boring did not reach the Pittsburgh coal, and hence the identification of the 6 -foot coal bed, 142 feet above the base of the section, is made on the same basis as that of the 5-foot bed 150

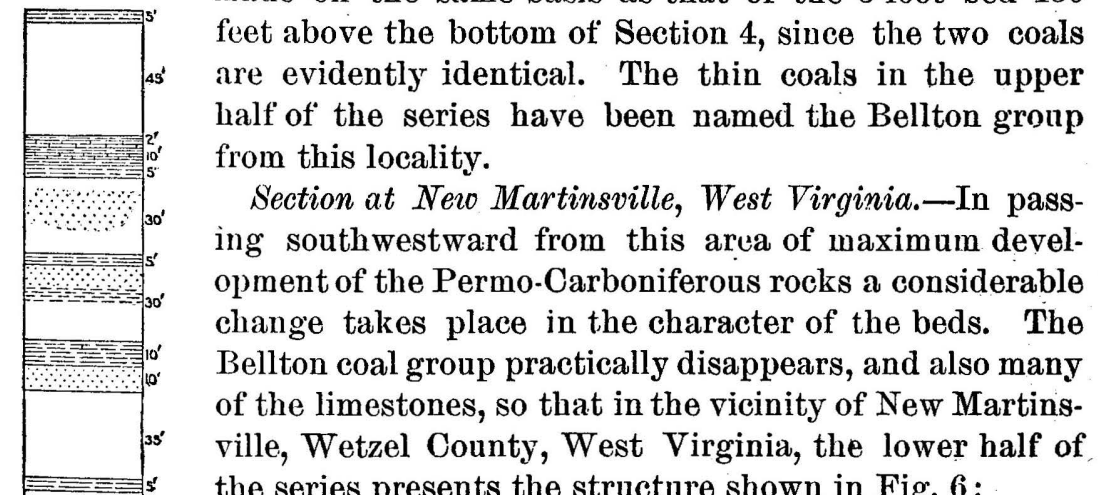
New Martinsville, Wetzel County, Wesi Virginia.

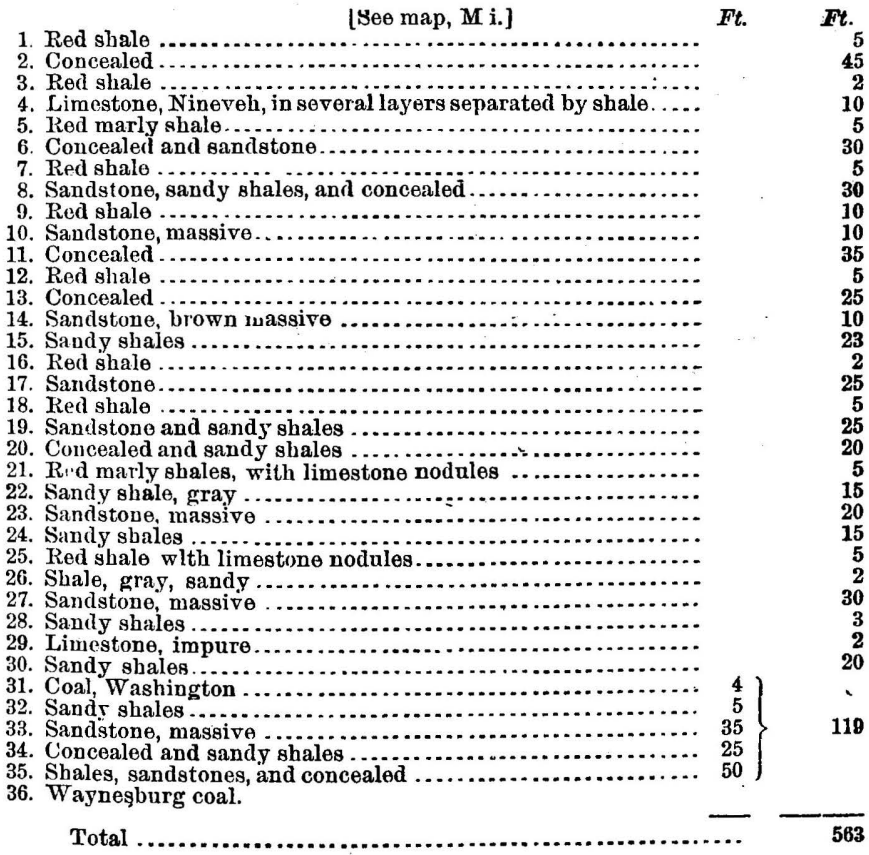

Fig .6.-Section at. New Martinsville, W, Va. 
No. 4 appears to represent the Nineveh limestone, though its inter. val above the base of the series is less here than usual.

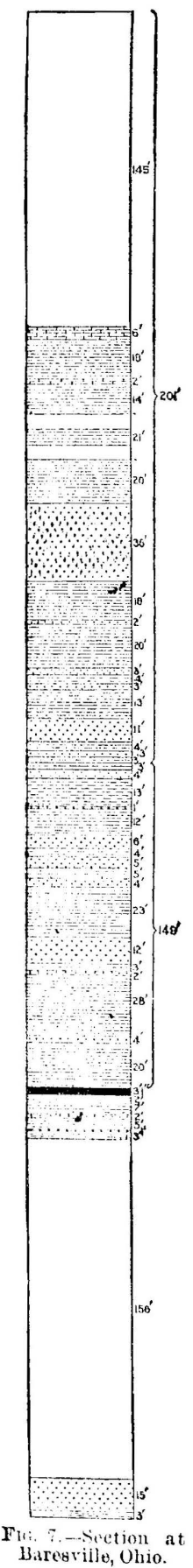

Not a single one of the Beliton coals was observed in this section, though some of them may have been pres. ent and concealed.

Section at Baresville, Ohio.-In the vicinity of Bares. ville, Mouroe County, Ohio, a long section was made by the late Prof. E. B. Andrews. It is referred to in vol. II, Ohio Geology, page 587, and published on Map XIII, section No. II. The locality is only $1 \frac{1}{2}$ miles above New Martinsville, West Virginia, and the snceession reads as follows (Fig. 7):

Baresrille, Womroe County, Ohio.

[See map, M i.]

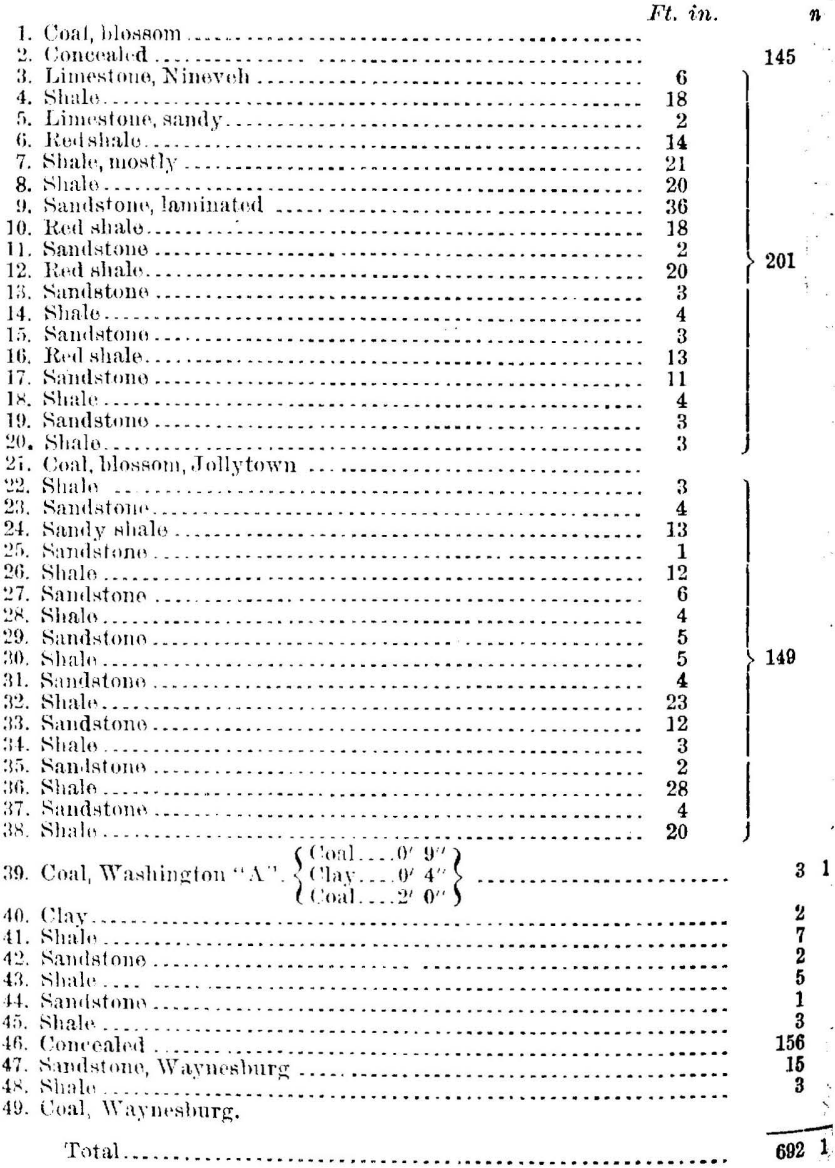


The coal blosson at the summit of Section 7 appears to come at a horizon above any of the Bellton beds, and hence is a new and prob-

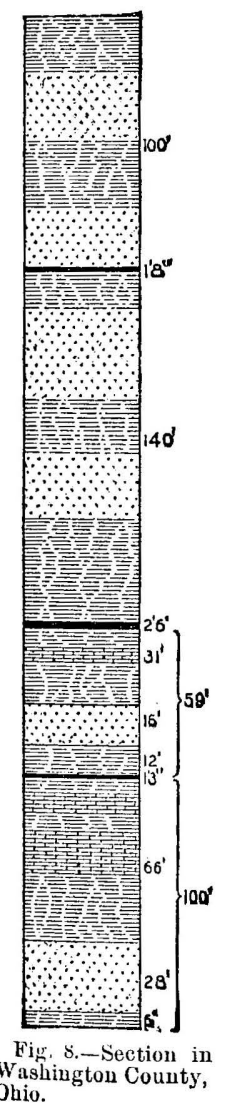

ably extremely local element in the series.

Section in Liberty Township, Washington County, Ohio.-The following (Fig. 8) succession of the beds in the lower portion of this series is reported by $\mathrm{Mr}$. F. W. Minshall from a hill near the Epler oil-boring in Liberty Township, Washington County, Ohio:

\section{Liberty Township, Washington County, Ohio.} [Seo map, M g.]

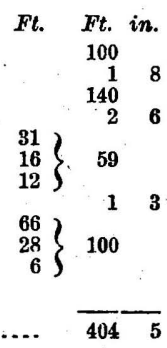

These identifications are made on the supposition that the Macksburg coal of the Ohio geologists is the equivalent of the Waynesburg bed.

Section at Washington, Pennsylvania.-In Washing. ton County, Pennsylvania, the Dunkard series, as alalready stated, contains much more limestone than elsewhere, and the intervals between the several nembers are somewhat less than in Greene County. The following section (Fig. 9) from Geological Survey, Penusylvania, Report $\mathrm{K}$, page 248, exhibits the structure of the lower portion of these beds at Washington, Pennsylvania :

Washington, Pennsylvania. [See man, J l.]
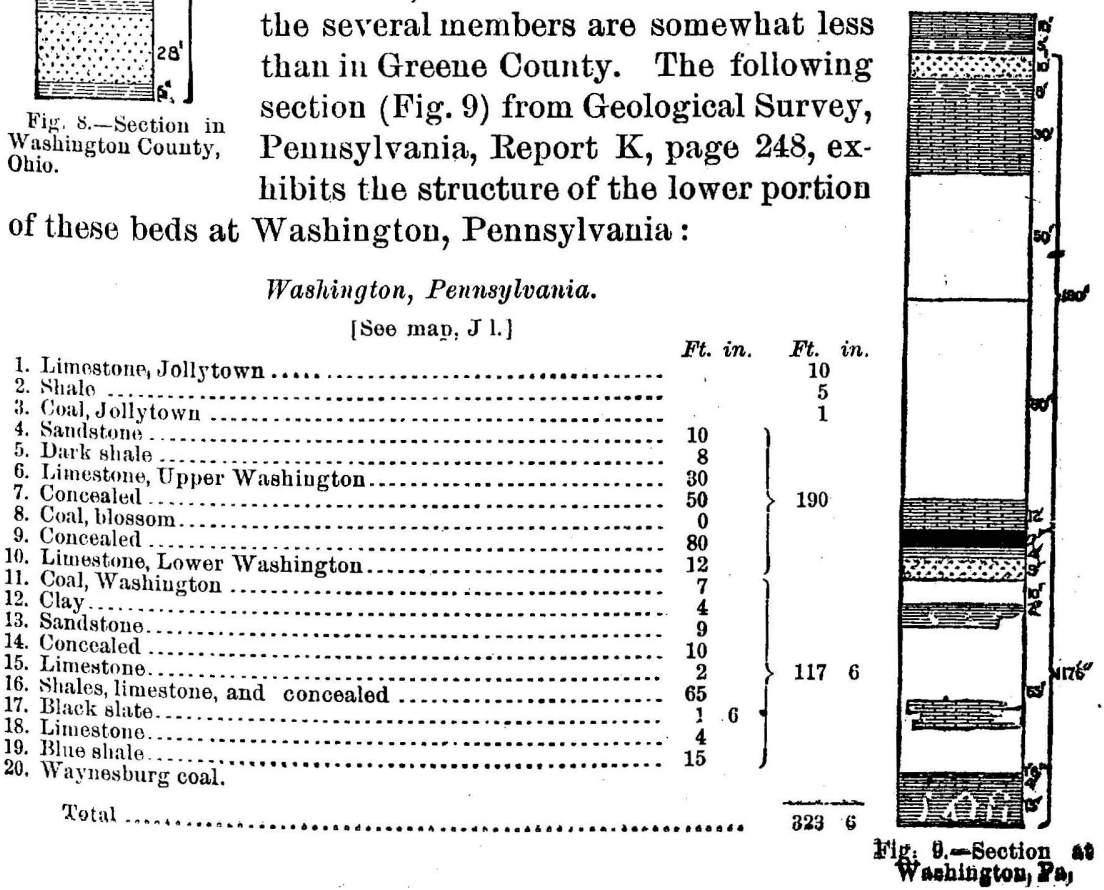
Section near Taylorstown, Pennsylvania.-Another section, from the same volume page 259 , exhibits the succession in the lower half of this series in Bulfalo Township, Washington County, Pennsylvania, as shown in Fig. 10.

In both these sections (9 and 10) the writer has changed the identi. fications of some of the berls (notably that of the Jollytown coal) from that male in the original sections by Stevenson, but in every such case the change is clearly warranted, since the coal in question was placed too near the Washington coal by Stevenson.

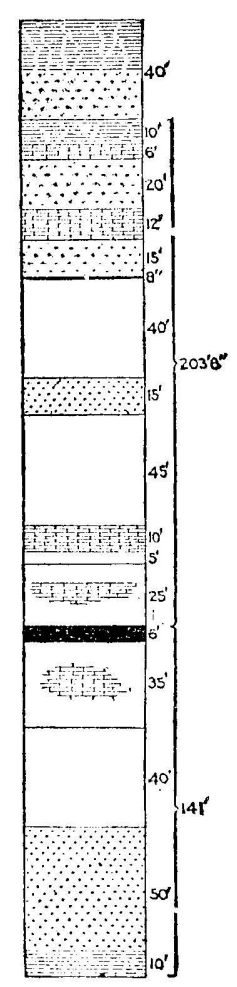

Near Taylorstown, Washington County, Pennsylvania.

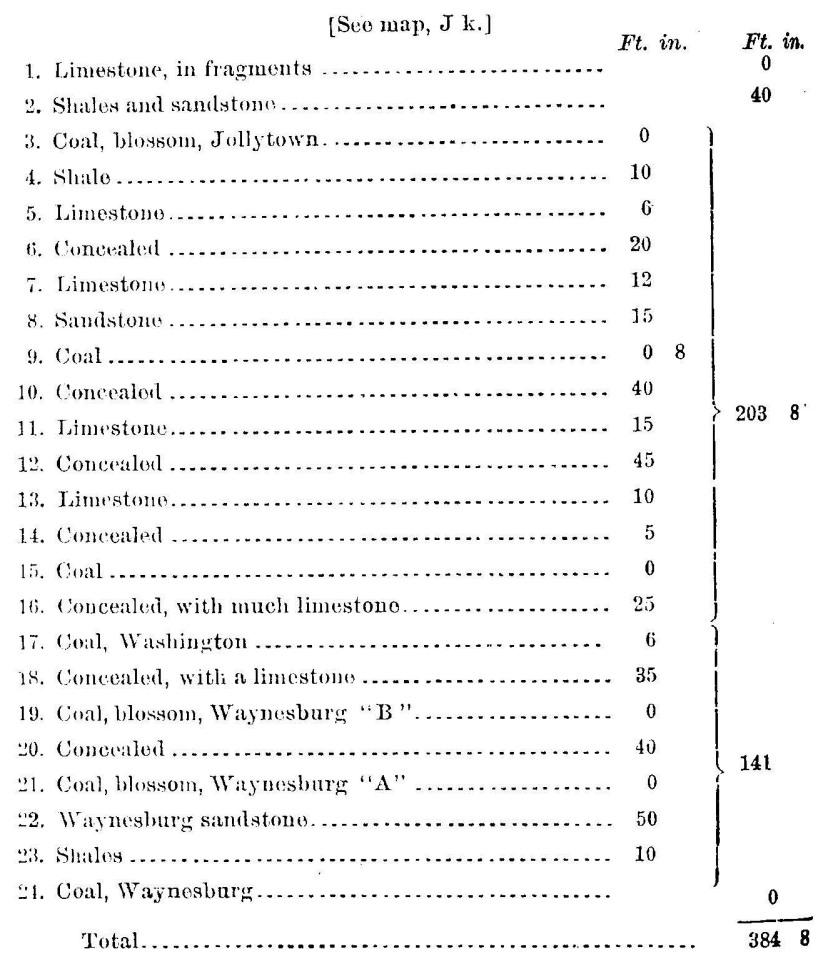

liti. 10. - Sicelion near 'Taylorstown, I'a.

The very highest beds of the Dunkard Creek series known to the writer ocenr in Shonglh's Knol, at the head of Dunkard Creek, Gilmore Township, Greene County, Penusylvania, but these are concealed by $\mathbf{a}_{1}$ thick covering of soil, and hence could not be seen in detail. The highest rock of the series which has been traced over any considerable area is the Windy Gap Limestone.

\section{CHAR ACTERISTIS HORIZONS.}

THE WINDY GAP LIMESTONE.

This has been named from its occurrence near. Windy Gap, a "divide" separating the Laurel Run branch of Fish Creek from the waters of Wheeling Creek, in Springhill Township, Greene County, Pennsylvaniaa 
The stratum is usually of a bluish gray color, quite pure, and has a thickness of about five feet. It contains minute fresh water fossils, and occasionally small crystals of blende.

The only land geologically and topographically high enough to catch this stratum is that which clusters about the southwestern corner of Pennsylvania, in Greene County, and the adjoining regions of Marshall, Wetzel, and Monongalia, in West Virginia. Only one point (Hunsucker's Knob) in the last county is high enough to catch this limestone, since its outcrop ranges between 1,500 and 1,600 feet above the sea. The sections (Figs. 3 and 4 ) at Board Tree and Bellton, in Marshall County, as well as the one (Fig. 2) in Aleppo Township, Greene County, show this stratum near their summits, but its horizon is concealed in Shough's Knob of the Dunkard Creek section (Fig. 1).

This is the same stratum as that numbered Limestone XIV by Prof. John J. Stevenson in his Report K, Second Geological Survey of Pennsylvania.

THE WINDY GAP COAL.

At an interval of 25 to 30 feet below the limestone just deseribed there occurs a small coal bed just under the summit of the "divide" at Windy Gap, Greene County, Pennsylvania, and it has been designated from that locality. No opening into it has ever been made, and hence it is known only as a blossom which exposes one to two feet of coal and black slate, the latter filled with the fossil Cypris, or a closely allied form.

The same bed was also seen in Aleppo Township, and in the summit of the hills at Bellton. It is the highest known coal of the series, and comes about 1,050 feet above the Waynesburg bed.

THE GILMORE SANDSTONE.

Crowning the upper portion of the Permo-Carboniferous beds over a considerable area around the heads of Dunkard, Wheeling, and Fish Creeks, there occurs a very massive sandstone having a thickness of 25 to 40 feet. It was named the Gilmore sandstone by Professor Stevenson, from its occurrence in the township of that name in southwestern Greene County. This stratum is usually a coarse and very massive sandstone, excellent for building purposes, and often forming long lines of cliffs on the summits of the high ridges. These cliff's are always traversed with fissures, and they furnish a convenient retreat for foxes when chased by hounds, so that the stratum in question is often locally known as the "Fox rocks," and again it is named from the farms where the cliffs occur, as "Pethtle" rocks, "Efaw" rocks, etc. This stratum has been the main agency in preserving all of the very high beds of the Permo-Carboniferous from erosion.

The interval below the Gilmore sandstone for 200 to 250 feet consists of red shales, occusional thin limestones, and gray sandstones, but con- 
tains no beds sufficiently characterized to be identitiable orer any considerable area.

THE NINEVEH SANDSTONE.

At 225 to $2 \tilde{50}$ feet below the Gilmore sandstone, we come to another great sandstone deposit which, from its good development near the village of Nineveh, Greene County, Pennsylvania, has been designated from that locality. Like the Gilmore sandstone above, it is usually an excellent building stone, and has long been used for that purpose on the Baltimore and Ohio Railroad, near Littleton, Wetzel County, West Virgiuia, where it crops out in a great cliff along the hills 150 to 200 feet above creek level.

This same stratum may also be seen in the hills two miles above Jollytown, Greene County, where it has long been quarried on the land of Thomas White for building purposes. It is of a yellowish gray cast, rather coarse-grained, but soft, and splits readily into rectangular blocks.

THE BLLLTON COAL GROUP.

At 275 to 300 feet under the Gilmore sandstone we find the uppermost of a series of thin coals which, from their fine exposure at the village of Bellton, Marshall County, West Virginia, have been termed thê Bellton group. These coals, few of which are rarely more than one foot thick, occur within a rock interval of 200 to 300 feet, and when all are present, as in the Bellton section (Fig. 5), there are five distinct beds, though not all of them are persistent over any considerable area. The three beds given in the Dunkard Creek section (Fig. 1), viz, the Nine. veh, Dunkard, and Jollytown coals, are the most important members of the group. Interstratified with these coals are shales, sandstones, and two important limestones.

TIL NINEVEII COAL.

This is the uppermost member of the Bellton group, and was named from the village of Nineveh, Greene County, Pennsylvania, by Professor Stevenson.

The coal rarely exceeds one foot in thickness, yet it is generally quite pure, and is frequently used for smithing purposes.

In the hills at bellton it crops out 290 feet above Fish Creek, and the same coal is seen in the railroad eut at the western portal of Board Tree Tumel, 75 feet above track level.

On the head waters of Dunkard Oreek it is known as the John Taylor coal, and although only one foou thick is highly valued as a smithing fuel.

THE NINEVEH LIMESTONE.

Below the Nineveh coal at an interval of 25 to 30 feet there comes a limestone which has a very extended distribution. It was called Limestone No. $X$ by Professor Stevenson iu his Report K, Greene and Washa 
ington Counties, but itis here desiguated from the same village in Greene County whioh has given name to the coal and sandstone already described.

This limestone usually consists of several layers separated by shales the whole of which sometimes foots up nearly 20 feet, as in the section at Board Tree Tunnel (Fig. 4), but its usual thickness is seldom more than 10 feet. Frequently a stratum of bituminous shale is found interstratified with the layers of limestone. Some of the latter are quite pure, and furnish excellent lime. It has a very wide distribution, as may be seen from its presence in each of the first seven sections already given. The same stratum extends clear through to Jackson County, West Virginia, and nearly to the Big Kanawha River, where it occurs high up on the summits of the hills and is hence termed the "Ridge" limestone, by the farmers.

There is a fine exposure of this rock at Limestone Hill Post-office, on the Parkersburg and Charleston turnpike, near the corners of Wirt, Wood, and Jackson Counties, West Virginia. It is there nearly 30 feet thick, in several layers, and contains many minute fossils, all apparently of fresh-water types.

THE HOSTETTER COAL.

Occasionally a bed of coal occurs at 75 to 100 feet below the Nineveh limestone. It has been stripped out of the run on the old Hostetter furm near Burton, Wetzel County, West Virginia, where it is 12 to 15 inches thick and rather pure. It also appears to be present in some localities near the head of Duukard Creek, and in a local section near Bellton it was seen 15 inches thick at 130 feet below the Nineveh coal.

THE FISH CREKK SANDSTONE.

At 135 to 150 feet below the Nineveh coal, there often occurs a very massive sandstone. It makes the great cliffs along the waters of Fish Creek in Springhill Township, Greene County, Pennsylvania, and was designated from this stream by Stevenson in his Report $\mathrm{K}$.

The rock in question is frequently quite massive, and it makes an excellent building stone. It is very conspicuous in the region of Deep Valley, Penusylvania, where it forms long lines of vertical cliffs 25 to 30 feet high. It may also be seen in cliffs along the Baltimore and Ohio Railroad, above Littleton, in Wetzel County, where it is quarried for building purposes.

THE DUNKARD COAL.

Below the Fish Creek sandstone, at an interval of 1 to 20 feet, another coal bed is often found, which, from its occurrence along the bed of Dunkard Creek for a considerable distance, was named the Dunkard coal by Professor Stevenson. It is seldom more than 12 to 15 inches thick, but is almost invariably double, having a thin layer of slate near its Bull. $65-3$ 
center. At Deep Valley, Pennsylvania, however, this parting thick. ens up to fire feet or more and thus separates the coal tuto two well. defined beds, each of which is 8 to 10 inches thick. In the roof shales of this coal at Mr. Lee Garrison's, in Gilmore Township, Greene Comnty, Penusylvania, fincly preserved fossil plauts abound, principally of the genera Neuropteris and Odontopteris.

This bed is frequently stripped along the streams for local use in Greene, Monongalia, Wetzel, and Marshall Counties.

THE JULLYTOWN LIMESTONE.

Below the Dunkard coal, at an interval of $\$ 5$ to 30 feet, there oceurs a bed of limestone which is rather persistent. It is well exposed in the vicinity of Jolly town, Greene County, Ienusylvania, and has been designated from that locality. As may be seen from its presence in Sections 1 to 5 and also in 9, this limestone has a wide distribution, though at the head of Dunkard (Fig. 1), and on Fish Creek (Fig. 5), the stratum is only 1 to 2 fect thick. In Washington County, Pennsylvania, how. ever, it thickens up to 10 feet or more and is usually a rather pure lime. stone.

THE JOLLY'TOWN COAL.

This is the lowest member of the Bellton coal group, and underlies the Jollytown limestone by an interval of 25 to 30 feet. The coal was named by Professor Stevenson from a village in Greene County, Penn sylvania.

This is the only coal of the Bellton group that ever attains dimen. sions of 2 to 3 feet, and can therefore be mined by drifting, since in the vicinity of Wise, Monongalia County, West Virginia, and below this along the South Fork of Duukard Creek, it is nearly 3 feet thick, and is mined to a considerable extent for local use. The coal is not very pure, but in the absence of auy other beds it finds a ready market. In the Bellton section (Fig. 5) this coal has been identified with the lowest bed exposed there. This is only a few inches thick and quite slaty, so that it is possible the Jollytown bed is the one next above, and which in that section has been referred to the Dunkard coal.

Along Dunkard Oreek the Jollytown coal is nearly always presert, and seldom less than 1 to 2 feet thick. It becomes a very inportant

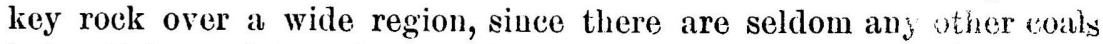
below it for an interval of 250 feet. It extends almost without a break across Greene, Monongalia, Marion, and Harrison Counties, but appears to thin away in Dodrlridge.

Throughout Monongalia, Greene, and Marshall Counties, the interval between this bed and the Washington coal below is about 275 feet, but westward, in Washington County, Ohio (Section 8), the intervol thins away to 200 feet, and practically the same measurement is found in Washington County, Penusylvania (Sections 9 and 10). 
THE UPPER - WASHINGTON LIMESTONE.

Three limestones were named from Washington, Penusylvania, by Professor Stevenson-an Upper, Middle, and Lower one-and two of these are shown in the section (Fig. 9) from the typical locality.

The Upper Limestone is a very important bed in Washington County, since it has a thickness of 20 to 30 feet, and is generally very pure. It is ustally of a dark blue color, and is much used for macadamizing roads and buruing for agricultural and other purposes. This rock appear's to be identical with the limestone seen in the bed of Dunkard Creek near the mouth of Negro Run, above Jollytowu, Greene County, Penusylvania, where it carries a bituminous shale on its top, filled with fish remains and other minute fossils, and underlies the Jollytown coal.

In the bell of Fish Creek at Bellton, Marshall County, West Virginia, we find a limestone with a fish bed on its top, which appears to be identical with the Upper Washington deposit.

THE MIDDLE WASHINGTON LIMHSTONE.

Abont midway in the interval between the Upper Washington limestone and the Washington coal there is frequently found another limestone bed. It is very persistent in Washington County, Pennsylvania, and is often 15 to 20 feet thick and of a buffish color.

On Dunkard Creek it appears to be represented by a stratum seen just above the road at Kent's Mills, where it is only three feet thick. This limestone, like all of those in the Dunkard series, contains minute, undetermined fossils, and the bituminous shales accompanying them hold plenty of fish scales, teeth, etc., as well as fragments of plants.

$$
\text { WASHINGTON "A" COAL. }
$$

At 70 to 80 feet above the Washington coal, there occurs a bed of impure coal and coaly shale which is often present in the section along Dunkard Creek. Sometimes the entire bed is four to five feet thick, but little of it is ever merchantable coal, being seldom more than a bituminous slate. It is well exposed in the hills about Blacksville, and Brownsville, in Monongalia County, and there contains many bivalve crustaceans.

Bituminous shale is often found at this horizon in Washington and Greene Counties, Pennsylvania, and in Washington County, Ohio (Fig. 8), a coal bed $2 \frac{1}{2}$ feet thick seems to occur at the same place in the series.

THE MARIẸTTA SANDSTONES.

The Washington "A" coal is often absent, and the portion of the series for 100 to 125 feet above the Washington coal is then frequently occupied by two or three beds of massive sandstone. These crop out in the hills below Marietta, Ohio, where they have long been extensively quarried for grindstones and building stone, and they have been 
designated from that locality. There are often three of them, each 25 to 40 feet in thickness, and separated by thin shales, so that in such cases they might be called the Upper, Middle, and Lower Marietta sandistones. Sometimes, however, as near Rock Lick, Marshall County, West Virginia, the shales thin out and let all of tho sandstones coalesce into one mass more than 100 feet thick.

These beds form the great cliffis at Raven Rock, Pleasants County, West Virginia. The upper one is extensively quarried at the Jackson quarry in Parkersburg, West Virginia, and it with its associated rocks forms long lines of cliffs up the Little Kanawha River, where they have been extensively quarried in the vicinity of Elizabeth and other points.

It is one of these beds that makes the big cliff's on the hill above the famous McGugan gas well in Washington County, Pennsylvania. These rocks are sometimes gray, but more frequently of a yellowish or buftish cast, and moderately coarse in grain. They also occur in Ritchie, Wirt, Jackson, and Putnam Counties, West Virginia, where they cap the narrow ridges in long lines of eliffs.

In Greene and Washington Counties, Pennsylvania, and Monongalia County, West Virginia, this interval of 100 feet above the Washington coit is generally occupied by shales, limestones, and thin, sandy beds, massive sandstones being exceptional.

\section{THE BLACKSVILLE LIMESTONE.}

In some portions of Washington, Greene, and Monongalia Counties, a limestone occurs with considerable persistency at 30 to 50 feet above the Washington coal. 'This was numbered Limestone 1II by Professor Stevenson in his Greene and Washington report, but as it comes to the surface near the bed of Dunkard Creek, in the village of Blacksville, Monongalia County, West Virginia, it has been given a geographical name from that locality. 'The rock is generally gray, quite pure, and only three to five feet thick. It is seen in Section 2 at 46 f'eet above the Washington coal. It soon disappears southward from the Penusylvania line.

THE LOWER WASHINGTON LIMESTUNE.

At Washington, Pennsylvania, a limestone of unusual thickness (20 feet) forms the roof of the Washington coatl, and it was designated, from that locality, the Lower Washington limestone by Stevenson. It has a wile distribution in Greene, Washington, Ohio, Belmont, Marshall, am Monongalia Comnties, but disappears southward from these. It often attains a thickness of 20 to 30 feet in Washington County, but is always interstratified with much shale, and outside of Washington Gomity is seldom more than 5 to 10 feet thick. Frequently some of the layers contain so much carbonate of iron as to prove a fair ore. 'These iron-bearing layers aro often interstratified with bituminous shales, and in such cases the iron layers are covered with fossil plants. It is on 
these thin, shaly layers of carbonate of iron in the roof of the Washing: ton coal at Brown's Bridge, Dunkard Creek, on the West VirginiaPennsylvania line, that the Permian plant, Callipteris conferta, occurs as described in Report PP, Second Geological Survey, Pennsylvania, page 54 .

THE WASHINGTON COAL.

This bed, which is the only one in the Dunkard series that is workable over a wide area, was first described by the writer, and named the Brownsville coal from its occurrence at the village of that name in Monongalia County, West Virgini:t. Subsequently, however, the same coal was found in greater development at Wasbington, Pennsylvania, and it was designated from that locality by Professor Stevenson.

It is always a multiple bed, being separated into two or three layers by divisions of slate. Occasionally these divisions are numerous and the entire thickness of the bed is 8 to 10 feet, but in all cases the only pure or merchantable coal is the bottom portion, which seldom exceeds two and a half to three feet. The upper part of the bed is nearly al ways very impure, since it contains so much ash and slate as to constitute it a mere bed of richly bituminous shale.

This coal is much more persistent than any other coal of the PermoCarboniferous series, since it occurs everywhere in the northern area of these rocks, and does not disappear to the southwest except beyond the Little Kanawha River, in West Virginia, while in Ohio it seems to be persistent even to the south western margin of these deposits. In Washington and Meigs Counties, Ohio, it is frequently referred to by Professor Andrews as the Hobson coal.

Section at Farmington, Marion County, West Virginia.-The following section of this coal, taken near Farmingtou, Marion County, West Virginia, well illustrates the structure of the bed when it is thick:

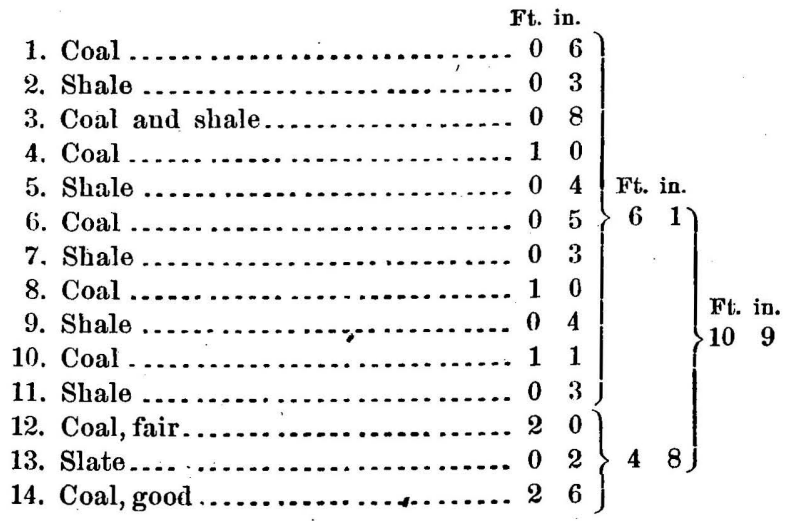

Here the upper or roof portion of the coal, although 6 feet thick, is entirely worthless, and the only really good coal in the bed is the $2 \frac{1}{2}$ feet at the bottom. 
Through Washington County, Pennsylvania, this coal has a thicknoss of 5 to 6 feet, but very lit tle of it is merchantable.

It is frequently exposed along the Ohio River hills between Wheeling and Parkersburg, being at low water in the latter town.

Before disappearing to the southwest it dwindles down in thickness very much, since at Harrisville, Ritchie Connty, it is only 2 feet thick, and at the Grahamite mines, near Hughes River in the same comuty, only 1.12 leet.

It is mined for local supply in the vicinity of Smithville, Ritchie Comnty, where it is only 15 inches thick and 150 feet above the level of Hughes River.

Section on IIilley Fork, Wetzel County, West Virginia.-At the mouth of the Willey Fork of Fishing Creek, Wetzel County, West Virginia, this coal is bronght a few feet above water level by a low, anticlinal roll, and there it exhibits the following structure:

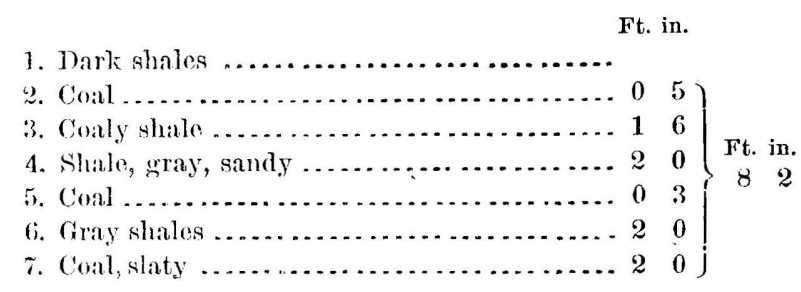

Section near Brown's Mills, Monongalia County, West Virginia.-Near Brown's Mills, Monongalia County, where this coal was first described, it has the following structure:

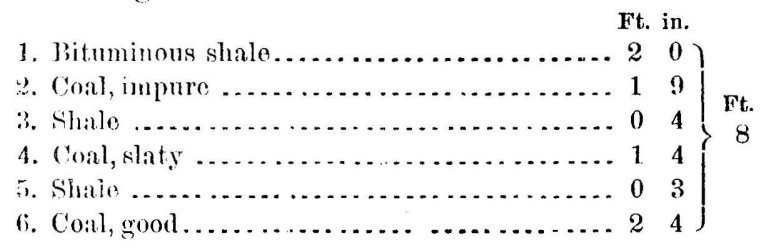

$\Lambda t$ this locality the Lower Washington limestone forms the roof above the hituminous shale No. 1 , and it also contains much iron.

Occasionally a thin coal is found resting immediately on top of the jower Washington limestone, and that condition of affairs exists at Brown's Mills, where a bed of coal and black slate, in all 2 feet thick, oceurs 10 feet ahove the top of the Washington coal. The bed is not misistent enough to merit a separate name, however.

TIIF WASIINGTON SANDSTONE.

Fery frequently no fire clay is present under the Washington coal, and the latter rests directly upon a flaggy sandstone, often finely laminated, brown, mieaceous, and containing vegetable fragments in great fuantity. This stratum, which was called the Washington sand- 
stone by Professor Stevenson, occurs over a wide area in Monongalia, Greene, aud Washington Counties, but is not persistent véry far south of the Pennsylvania line.

THE LITTLE WASHINGTON COAL.

Just under the Washington sandstone, and 10 to 20 feet below the Washington coal, there sometimes occurs a thin bed of coal, seldom attaining a foot in thickness. It is more persistent in Washington County, Pennsylvania, than elsewhere, and hence was designated as above by Stevenson. It is seldom seen south from the Pennsylvania line, and in Greene County eren is represented only by a thin bed of bituminous slate.

THE WAYNRSBURG "B" COAL.

Below the last littlo coal bed there usually occur shales, thin sandstones, and occasionally a limestone, down to about 45 feet below the Washington coal, where another small bed is found quite persistent in Monongalia, Greene, and Washington Counties. It is seldom more than a foot thick, but sometimes attains to two. It has never been seen south of Monongalia County, and is of little economic importance.

THE COLVIN'S RUN LIMESTONE.

Below the last coal come 30 to 35 feet of shale and thin sandstones, and then we get a limestone that was numbered Limestone I(a) by Professor Stevenson, but I have given it the above geographical designation from its occurrence at the locality of Section 2 , where it is 3 feet thick and quite pure. It is often of a buffish cast, however, and contains too much iron to slake well on burning. In Washington Comnty, Pennsylvania, this stratum thickens up to 8 and 10 feet, but it is seldom seen south of the Pennsylvania line.

THE WAYNESBURG "A" COAL.

This occurs just under the last mentioned limestone and like it is confined to the northern end of the Permo-Carboniferous area. It sometimes attains a thickness of 3 and 4 feet, but is generally slaty and worthless, so that it has seldom been mined. It occurs quite generally across Monongalia, Marion, and Harrison Counties, and is possibly present in Ritchie County near Harrisonville, but beyond that it has not been identified. Its horizon is usually 60 to 80 feet above the Waynesburg coal proper.

THE MOUNT MORRIS LIMESTONE.

Separated from the coal last described by only 2 to 5 feet of clayey shales there sometimes occurs a limestone which, although noted, was not named by Stevenson in his Report $K$. It is well exposed on the north bank of Dunkard Creek at Mount Morris, Greene County, Pennsylvania, and has been designated from that locality. The stratum 
is often only 1 to 2 feet thick, and seldom more than 5 feet except in Washington County, Pennsylvania, where it is occasionally thicker.

This limestone is not persistent, and is seldom found south of the Pennsylvania line, being frequently absent even in Greene and Washington Counties.

THE WAYNESBURG SANDSTONE.

Just nnder the horizon of the Mount Morris limestone, and separated from it by 2 to 5 feet of shales and clay, there comes a very important sandstone. This was long ago termed the Waynesburg sandstone, from its fine development near the town of that name in Greene County, Peunsylpania. It is one of the most persistent members of the Permo-Carboniferous series, since it sastern outcrop can be followed in an almost constant line of eliff's from Greene County, Pennsylvania, clear across West Virginia to the Big Kanawha River at Winfield.

This stratum is the only one in the series that is generally conglomeratic or contains quartz pebbles larger than coarse sand grains. On account of this peculiarity the rock in question becomes a very important guile to the geologist in the interior of West Virginia, where so many of the Dnukard Creek coals and limestones have disappeared, for it retains its pebbly character over a very wide area. When at its greatest development the thickness of this stratum approaches 75 and even 100 feet. It is nsually a grayish white rock, with a yellowish cast on freshly broken surfaces, and its weathered bowlders are usually covered with ridges and streaks of harder iron-bearing sand. The rock splits readily and frequently furnishes excellent building stone, the piers of the Baltimore and Ohio Railroad bridges across the Monongahela River near Fairmont having been constructed of it.

Along the westem border of the ontcrop of this rock it dwindles down and changes its character entirely, being frequently represented in Washington Connty, Pennsylvania; Marshall and Ohio Counties, West Virginia; Belmont and Monroe Counties, of Ohio, by sandy shales and flaggy sandstones, and oceasionally even a stratum of limestone may be found at this horizon.

In passing down the Ohio Rirer below Marshall County the horizon of this samdstone passes below water level, but when it reappears near Saint Mary's, in P leasants Connty, the rock has regained its massiceness, and is a coarse pebbly andstone 50 feet thick, and from this point on down the Ohio River, whenever above the level of the same, it is always a massive sandstone. From Blennerhasset Island, below l'arkersburg, this rock is almost constantly visible either in the bed or blufts of the Ohio on down to 25 miles below the mouth of the (ireat Kanawha. It is the emergence of this stratum from the bed of the stream which makes Letart Falls in the Ohio River. It is this rock which forms the great cliffs in the top of the hills at Red Rock, in Put- 
nam County, on the Great Kanawha, and the same may be seen as a bed of pebbly sandstone at many points in Ritchie, one at the famous Grahamite mine being especially noteworthy, for it is the great sandrock through which the celebrated fissure extends at the base of the hills, and it is there $\mathbf{7 5}$ feet thick.

Through Ritchie, Gilmer, and Calhoun Counties a bed of brecciated limestone occurs at the base of this stratum and incorporated with it, which is quite persistent and seems to replace the usual underlying Waynesburg coal, which is there absent.

THE CASSVILLE PLANT SHALK.

The Waynesburg sandstone often rests directly on the underlying Waynesburg coal, but more frequently a bed of dark gray shale, 5 to 15 feet thick, interveues. This shale is al ways prolific in fossil plants and is especially so in the vicinity of Cassville, Monongalia County, West Virginia. It is from this locality aud horizon that so many of the fossil plants were obtained which are described in the Second Geological Survey, Pennsylvania, Report PP, by Fontaine and White, and it is from the same shale that so many plants of Permian and even Triassic types lave been procured, Tæniopteris, Saportæa, Baiera, and Pachypteris being among the number. No systematic search has ever been made at any other locality, and hence it is entirely probable that the list of fossil plants could be largely increased were this bed thoroughly explored in other regions. Other promising localities of the Cassville sbale which have been slightly explored are Carmichael's, Greene County, Pennsylvania; Georgetown, Monongalia County; and West Union, Doddridge Connty. In connection with these roof shales, and sometimes interstratified with the top members of the underlying coal, there occur at Cassville numerous remains of insects, the principal ones being fossil cockroaches, of which Gerablattina seems to be the principal genus.

\section{THE AGE OF THE DUNKARD CREEK BEDS.}

The fauna of these rocks has never been systematically studied and its relationships determined. What desultory work has been done in this line goes to show that the animal forms consist principally of minute shells of crustaceans, fish remains, and insects, many of which are probably undescribed. No Brachiopods have ever been seen in these rocks, and hence one important line of evidence which might help to determine their relative age is wanting. Some geologists have been inclined to regard them as belonging in the Carboniferous proper because of the absence of the Permian reptilian fauna, and other types common elsewhere, but as the deposits are mainly of fresh water origin, the absence of such types is to be expected. Hence until the minute fauna occurring in these limestones and black slates shall have been carefully studied, the geologist must rely on the evidence of fossil plants. 
These have been studied by Prof. Wm. M. Fontaine and the writer, the results being published in Report PP, Second Geological Survey, Pennsylvania. The conclusions there given show that the flora is closely and unmistakably allied to the Permian of Europe, since it contains so many types that are peculiar to those rocks or even related to Mesozoic forms. The facts and conclusions set forth are sufficient to convince Prof. Archibald Geikie that these rocks are of the same age as the reptiliferous bels at Antun.

The conclusion that these rocks are of Permian age has not been accepted by all American geologists, though none have given any reasons for discrediting the evidence of the fossil plants on which it is based, and until it is contradicted by the animal remains or otherwise shown to be erroneons, no other hypothesis is tenable in view of the evidence at hand. The list of plants from which the Permian age of these Donkard beds is inferred, together with the general discussion of the same, is giren in Chapter III, pages 105, 120, Report PP, Second Geological Survey, Pennsylvania.

The recent discovery of an undoubted Permian invertebrate fanna in Texas by Prof. C. $\Lambda$. White and Mr. Cummins (American Naturalist, February, 1859), confirms the conclusions of Profs. Cope and Marcon with reference to the existence of a great Permian series of rocks in this country, and hence there is no longer any reason for doubting that America contains deposits which are equivalent in part at least to the Permian of Europe. The Texas deposits, as deseribed by Prof. White in the article referret to, are so exactly similar lithologically to these uppermost beds of the Appalachian region, that the description of the one might well answer for that of the other, and there can be very little doubt that the two series are equivalent. Singularly enough the beds have practically the same thickness, 1,000 feet in Texas, and 1,100 in West Virginia and southwest Pennsylvania. 
C H A P T E R I I I.

THE UPPER COAL MEASURES, OR MONONGAHELA RIVER SERIES.

THIOKNESS, CHARACTER, AND EXTENT.

This series of rocks begins at base with the Pittsburgh coal and extends up to the Cassville shale. The thickness varies between 200 feet along the northwestern outcrop in Ohio and 380 feet in the Monongahela River region, but in the center of the Appalachian trough a boring at Browntown, Harrison Counity, West Virginia, carefully measured with steel line, reveals a thickness of 413 feet from the top of the Waynesburg coal to the bottom of the Pittsburgh bed.

Within the interval there belong six distinct coal beds, though only four of these are workable over any considerable area. These coals have their greatest development along the waters of the Monongahela River, and hence the series was long ago named after that river by Prof. H. D. Rogers.

The character of the rocks interstratified with the coal beds changes greatly in passing from the Monongahela River south ward to the Great Kanawha. At the northern end of the basin in Marion, Monongalia, Greene, Washington, Fayette, and Westmoreland Counties, limestone forms about one-half of the rock material, and the same is true on the western side in Brooke, Ohio, Marshall, and Belmont Counties. Red shale is unknown in the series at the north, but in passing south ward from Harrison and Lewis Counties the limestones practically disappear, and with them all of the coals except the Pittsburgh. With their disappearance red shales come in and apparently replace the limestones, so that on the Great Kanawha nearly one-fourth of the rock material in this series is red shale, while the thickness is rednced to 270 feet. Along with this change in the character of the rocks there occurs a great change in the topography made by these beds, for at the nortb, where limestone is abundant, sandstones are few and shaly, so that a gentle, rolling topography results, with a very rich soil and one of the finest grazing and farming regions in the country, while to the southwest, after the limestones have disappeared the sandstones thicken up and become more massive, thos giving ruggerl and precipitous slopes with narrow valleys. 
The character of the Upper Coal Measure rocks in the several portions of the area they occupy is shown by the several sections which follow. Section in Fayette and Westmoreland Counties, Pennsylvania.-Prof.

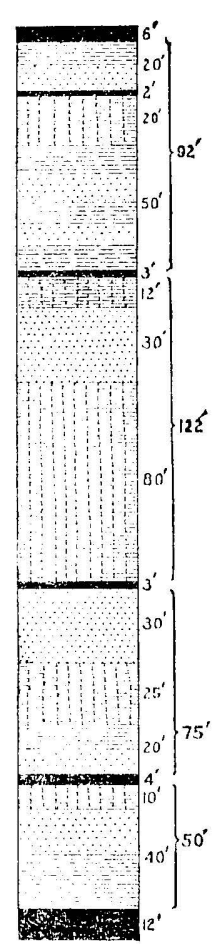

Fri: 11.--sicetion in Fityettesand West. morelitul ('0)11" ties, li: Stevenson, who has done so much to elaborate the detailed structure of this series, gires the following (Fig. 11), in Second Geological Survey, Pennsylvania, Report KK, page 31, as the general section of these beds in Fayette and Westmoreland Connties:

\section{Fayette and Westmoreland Counties, Pennsylrania.}

[See map, K n.]

1. Coal, Wayneaburg

2. Simly shales or sandistono

3. Coal, Little Waymeshurk

4. limestone, Wajneshmrg.

5. Shale and shaly samblone

6. Coal Uniontew'

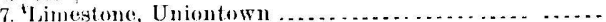

s. Sindstone

๑. Limestome "Gimit"

11. Coul, Sowickleg . . . .

11 Simelstome.

1․ Limestome, Sewickley . . . . . . . . . . . . . . . . . .

13. Shate or shaly sandstone.

1.1. Cosil Ioulatume.

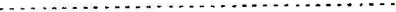

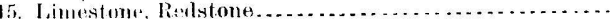

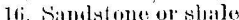

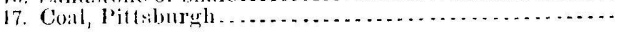

Jotit.

Sectim at Bromsuille, Pennsylrania-Dt Brownsville, Fayette County, Pennsylvania, Prof. Stevenson finds the following structure, (Fig. 12), for this series, as given in $\mathrm{KK}$, page 233 :

Brownswille, Fayette County, Pennsylrania.

[sie map, K m.]

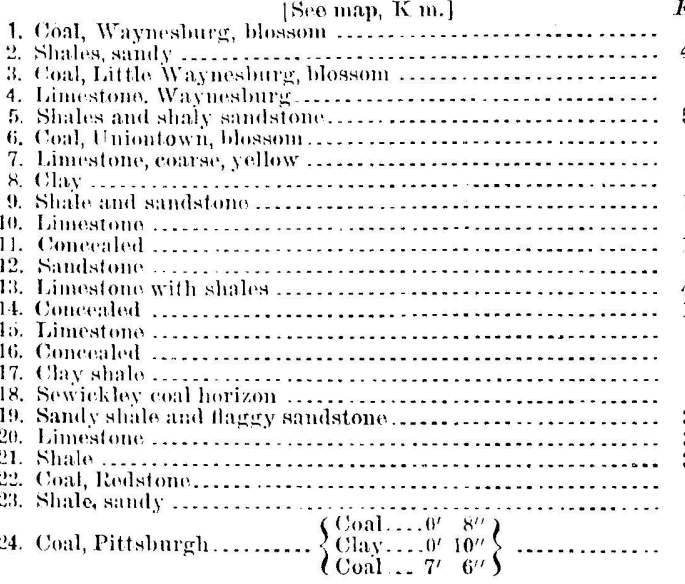

Total.

Ft. in.
45
0
4
55

$\vdots$
3
16
2
17
3
43
16
6
7
8
30
30
35

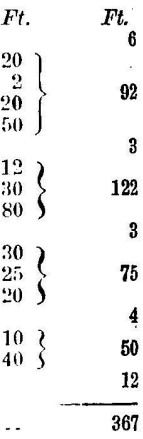




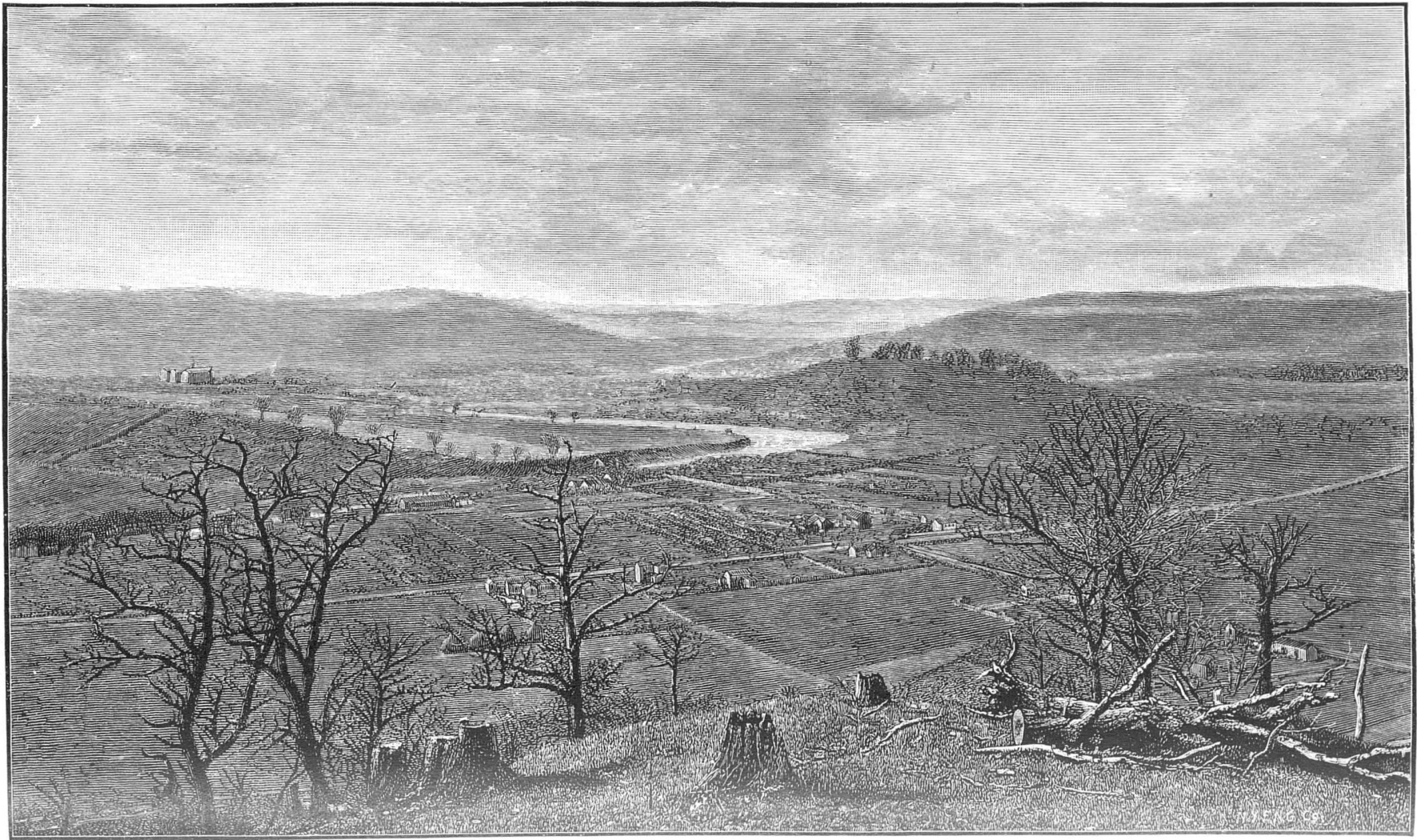

UPPER COAL MEASURES CAPPED WITH PERMO-CARBONIFEROUS BEDS, WHEELING, WEST VIRGINIA. 

Section at West Brownsville, Pennsylvania.-On the opposite side of the Monongahela River, in descending from Kreb's Knob to West

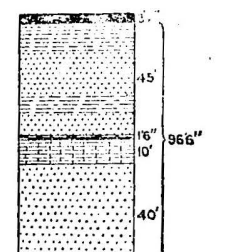
Browusville, in Washington County, the writer measured the secieral members of this series with the following results (Fig. 13):

West Brownsville, Washington County, Pennsylvania.

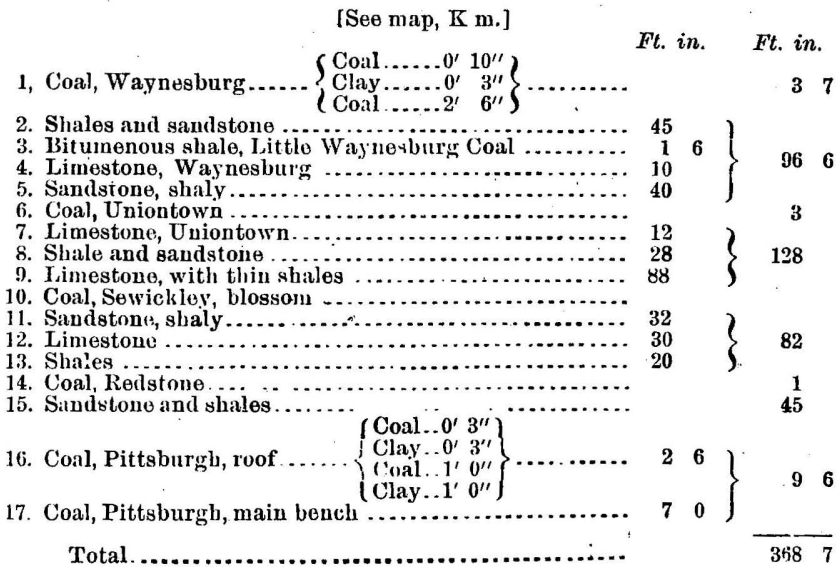

Section at Rice's Landing, Pennsylvania.-In the steep hillside, one mile below Rice's Landing, Greene County, Penusylvania, the series exhibits the Fin. 13.-Section at West Browesville, following structure (Fig. 14): $\mathrm{Pa}$.

Rice's Landing, Greene County, Pennsylvania.

[See map, $\mathrm{K} \mathrm{m}$. ]

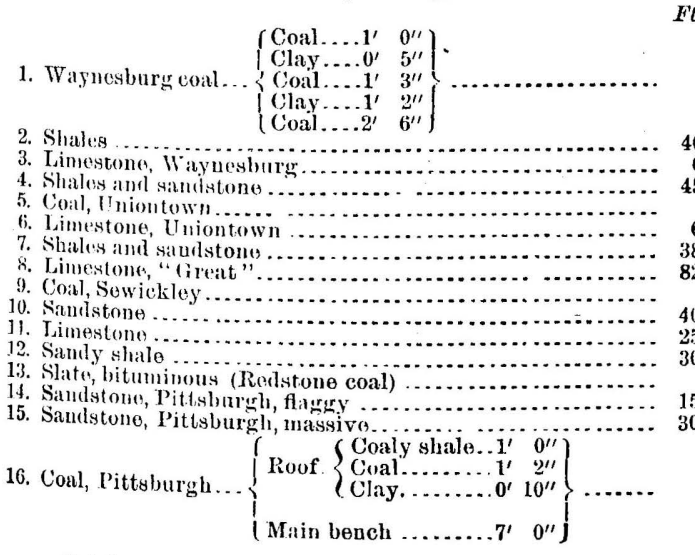

Ft. in. Ft. in.

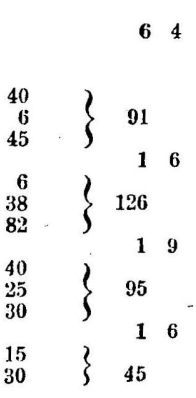

\} 45

Total
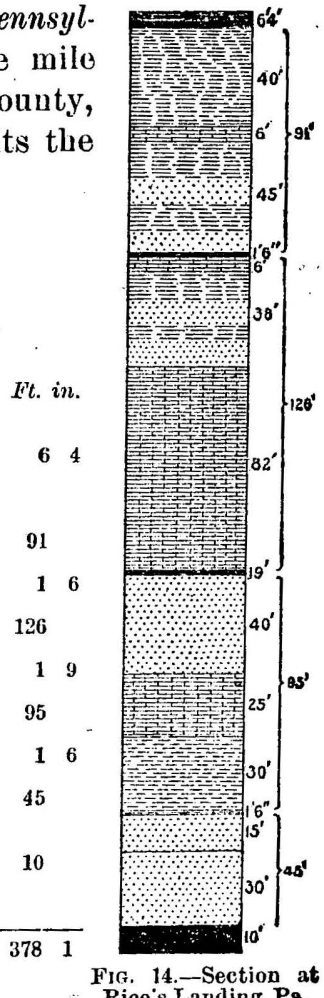

FIG. 14.-Section at 
Section on Lobinson's Run, West Virginin.-The Upper Coal Measure beds attain a very fine development in Monongalia County, West Virvinia, just south from the Greene County line, and there, on Robill: son's Run, 2 miles west from the Monongahela River, the following: stlccession (Fig. 15) is exposed:

Liobinson's Liun, Monongalia Counly, West Virginia.

[Sues map, L m.]

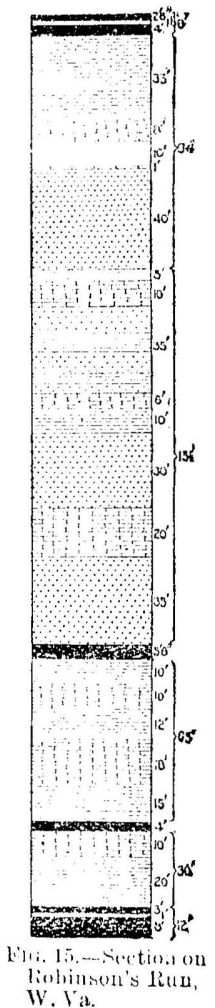

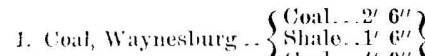

Ft. in. $\quad F$. in

$\therefore$ Sandy inales with iron ore below middle............ 35

3. Limestume, Waynesburg ......................... 8

1. Silntley................................. 10

5. Limestone..................................... 1

6. Sandstone, flatgry $\ldots \ldots \ldots \ldots \ldots \ldots \ldots \ldots \ldots \ldots \ldots \ldots .40$

7. Blatis slate (Uniontown coal) ................... 5

8. Limbstone, Uniontown ........................ 10

9. Samdstone and sbales. ........................ 35

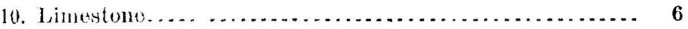

11. Slitiles. . ..................................... 10

12. Similutone, flagriry ........................... 30

13. Limestone, cement beds....................... 20

14. Samlintone, Sowickley ......................... 35

15, Coal, Sewickley . . . . . . . . . . . . . . . . . . . . . . .

11j. Sltales.................................... 10

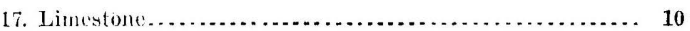

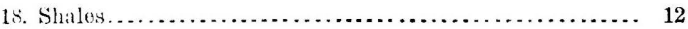

19. Limestono .................................. 18

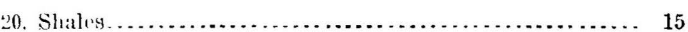

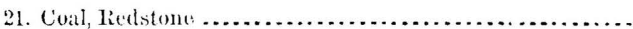

22. Limestone, Redstone..........................

23. Shales and slates. .............................. 20

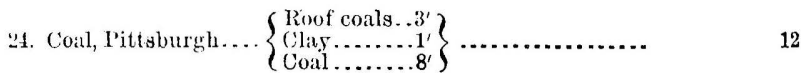

Total

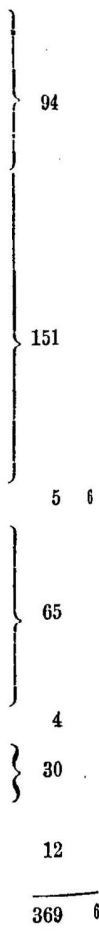

Ilere, as will be seen from the above section, the Redstone coal, which belongs between the Pittsburgh and Sewickley beds, has thick. ened "y into merchantable condition. This coal contains a little more sulphur than either the Pittsburgh below or the Sewickley above, but it makes a very fair fuel for domestic and steam.producing purposes. It is softer than either of the other two aud would coke well.

The Redstone, l'ittsburgh, and Sewickley beds of this section foot up a total thickness of $21 \frac{1}{2}$ feet, including partings, and about 17 feet of this is merchautable coal. 
Section on Scott's Run, West Virginia.-A short distance south from Robinson's Run, we get another fine exposure of the Upper Coal Measure beds along the waters of Scott's Run, between Cassville and the mouth of the stream, as follows (Fig. 16):

Scott's Run, Monongalia County, West Virginia.

[See map, M n.]

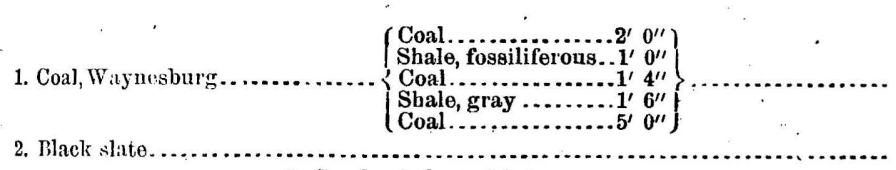

Ft. in. Ft. in.

10. 10

2. Black slate.

3. Sandy shales, with iron ore
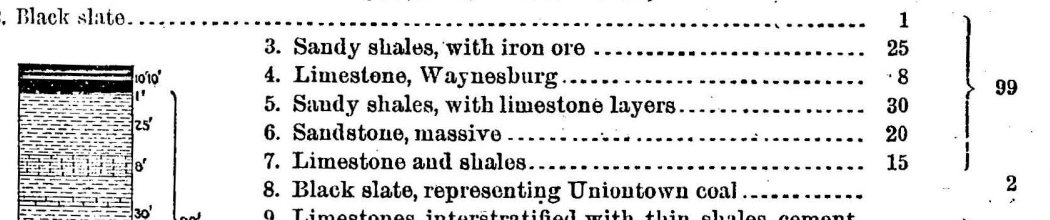

4. Limestene, Waynesburg.

5. Siudy shales, with limestone layers

6. Sandstone, massive .

7. Limestone and shales.............................. 15

8. Black slate, representing Unioutown coal.............

9. Limestones, interstratified with thin shales, cement bolls near base ..................................... 105

10. Sandstone, Sewickley ............................. 40

11. Coal, Søwickley ....................................

12. Shales ............................................. 5

13. Sandstone ......................................... 10

14. Limestone ....................................... 5

15. Shales, greenish gray ............................. 8

16. Concealed........................................ 15

17. Limestone, steel gray ............................... 7

18. Concealed ..................................... 15

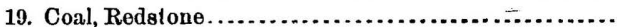

20. Limestone, Redstone................................. 18

21. Shale and fire clay .............................. 5

22. Slate, black .................................... 5

Coal.. $0^{\prime}, 3^{\prime \prime}$

23. Coal, Pittsburgh, roof

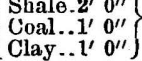

$4 \quad 3$

(Coal...3' 6 $^{\prime \prime}$

Slate $.0^{\prime} \frac{1}{2}^{\prime \prime}$

Slate...0, $0^{\prime \prime}$

24. Coal, Pittsburgh, main bench ..

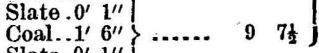

Total.

The same Redstone coal makes its appearance in this section; in fact it nnderlies all of the region intervening between Scott's and Robinson's Runs, thinning out south ward as well as north ward. It underlies an area of probably 5,000 acres where it is of workable thickness. In the oil-well borings on Doll's Run, and as far west as Mannington and Fairview, this bed is still present, though apparently not of workable thickness. 
Section on Buffalo Creek, West Virginia.-Along Buffalo Creek; in the vicinity of Fairmont, Marion County, West Virginia, the Upper Coal Measures exhibit the following succession (Fig. 17):

Buffalo Crek, Marion County, Hest Virginia.

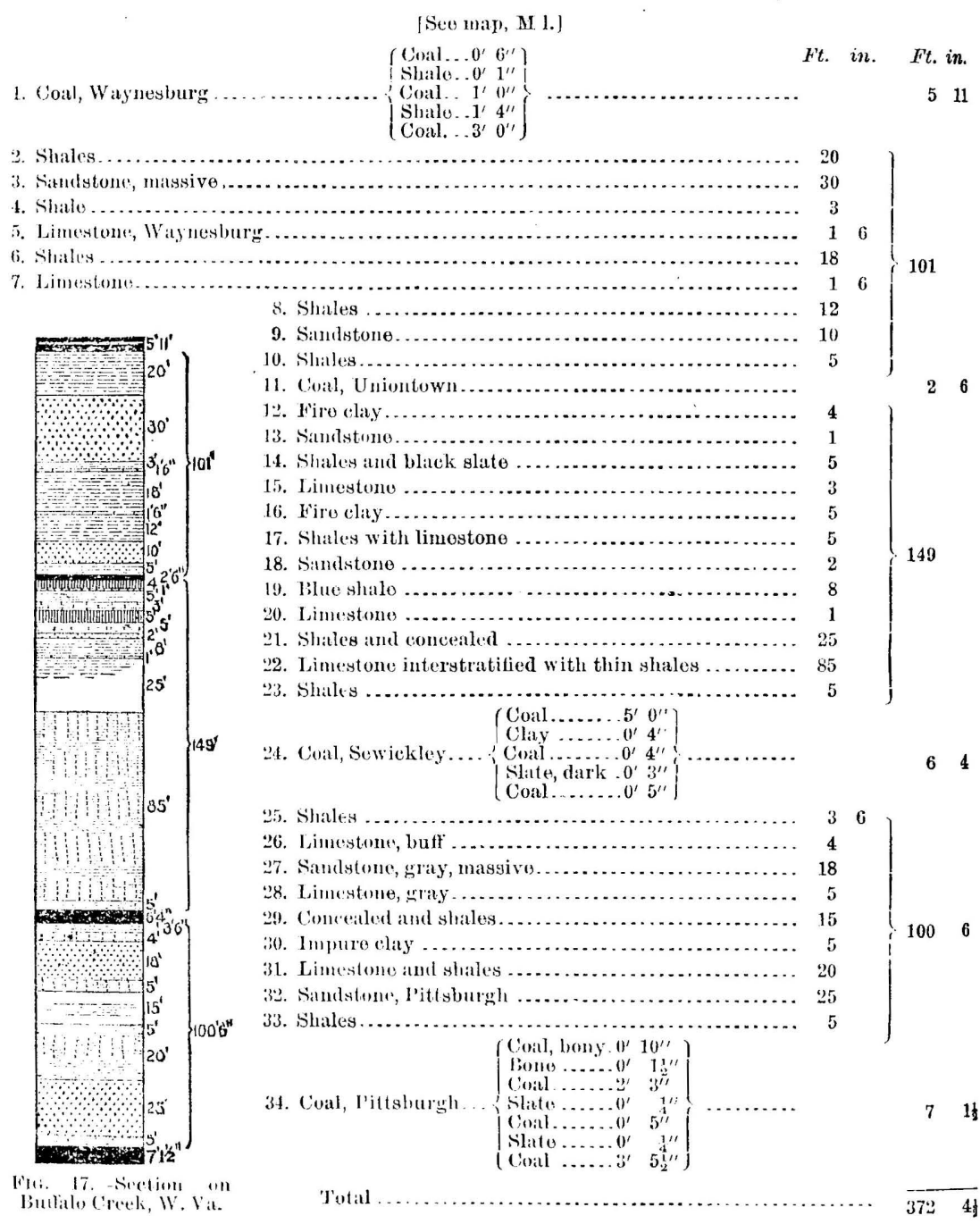

'The portion of this section from the Sewickley coal down to the base of the series was measured at the Montana mines, 2.2 miles below the month of Buffialo Creek.

The Redstone coal is entirely absent here, its horizon being occupied by the 5 leet of impure fire clay, 50 feet above the Pittsburgh bed.

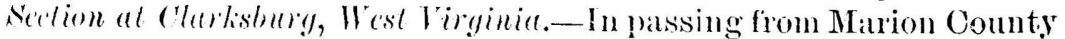
southward towards Charksburg, in Harrison County, a great change takes place in tho character of the sediments of the Upper Coal Meas. 
ures. The limestones, so prominent in Greene, Monongalia, and Marion, dwindle down to insignificant proportions, as shown by the following section (Fig. 18), made at Clarksburg by Mr. Jno. L. Johnston, civil engineer :

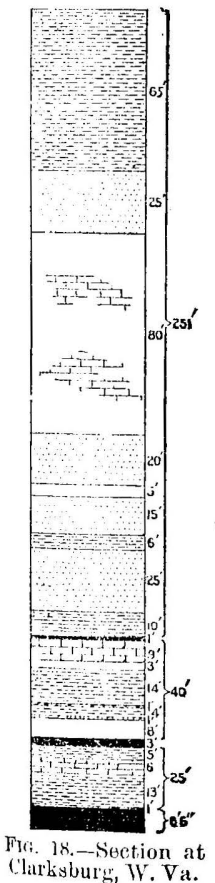

Clarksburg, Harrison County, West Virginia.

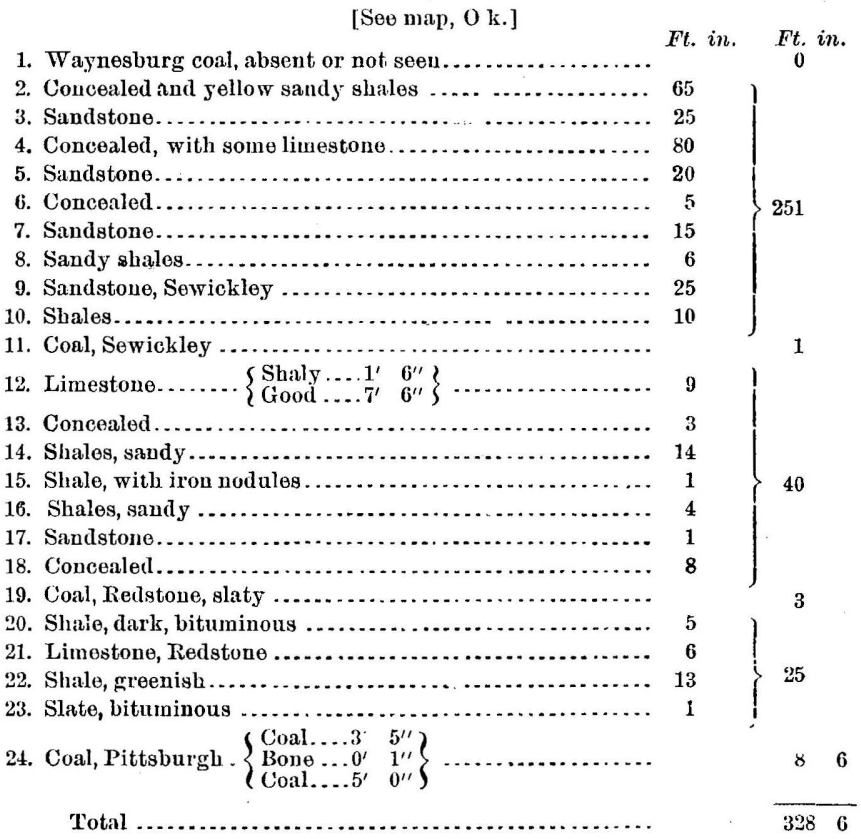

Section at Chapline Hill, Wheeling, West Virginia.-Between the Monongahela and Ohio Rivers a considerable change takes place in the character of the Upper Coal Measure beds, and also in the thickness of the several members, as will be seell by the following section (Fig. 19) from Chapline Hill, Wheeling, West Virginia :

\section{Chapline Hill, Wheeling, Thest Virginia.}
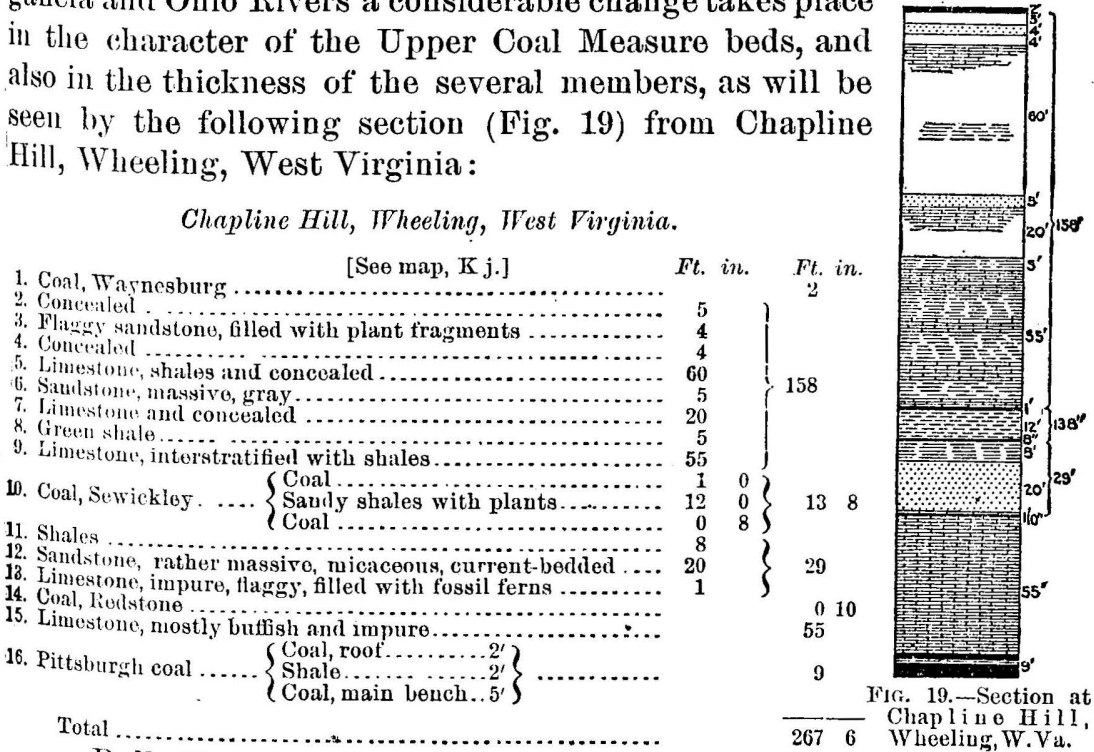

Bull. $65-4$ 
Here the Waynesburg coal has dwindled to an unimportant bed, and the Sewickley has split iuto two portions separated by 12 feet of shales, while the whole column has lost more than 100 feet of thick. ness compared with the Monongahela River region.

Section near Bellaire, Ohio.-At Bellaire, Ohio, 4 miles below Wheel. ing, the following carefully leveled section (Fig. 20) was made by Prof. C. N. Brown, of the present Ohio Geological Survey. It exhibits some interesting changes as compared with the Wheeling section:

Near Bellaire, Belmont County, Ohio.

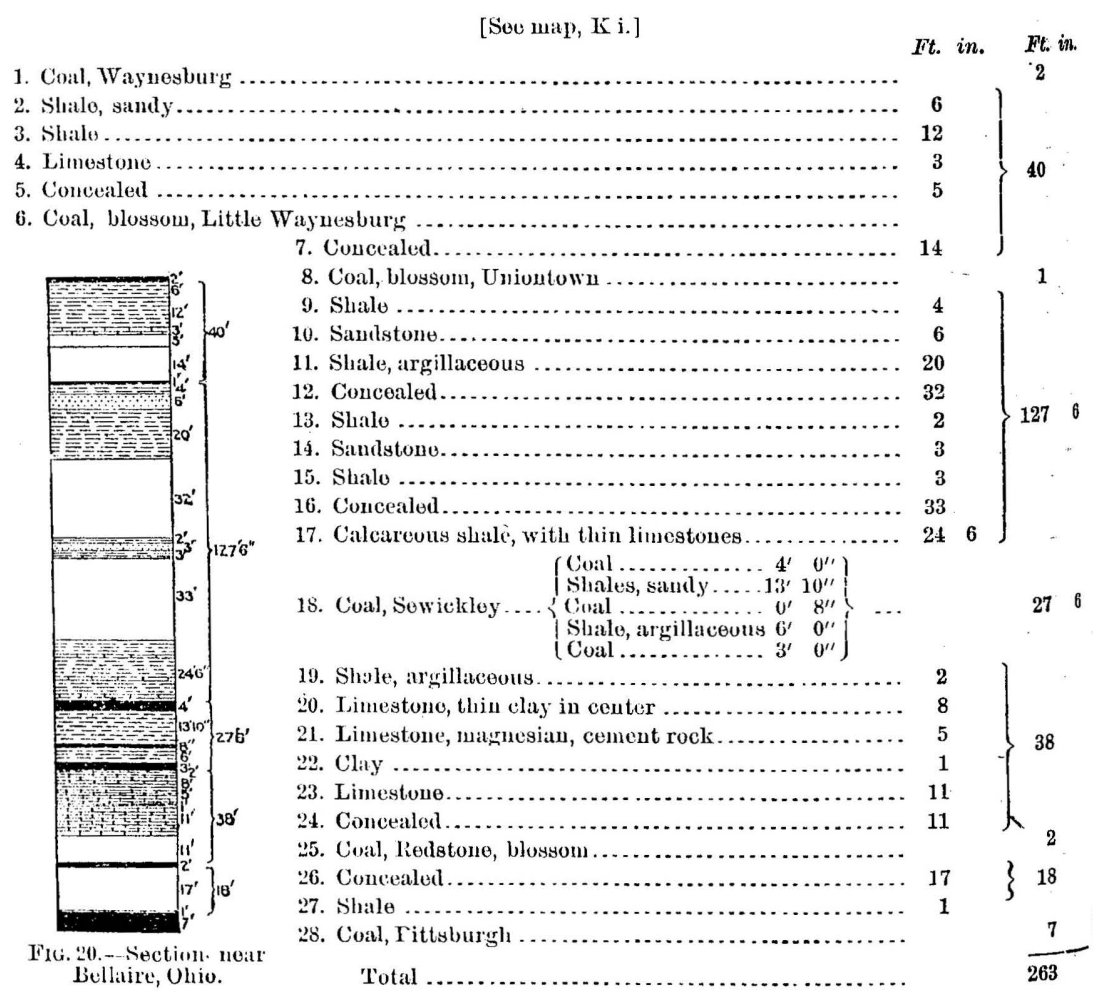

The interval between the two members of the Sewickley coal has here increased to 20 feet, and the upper one seems to keep permanentls above the lower one from here sonthwestward through Ohio, becoming the Cumberland and Meigs Creek bed of the Ohio geologists.

Both the Little Waynesburg aud Uniontown coals are represented in this section, but neither one was observed at Wheeling.

It is worthy of note that there is a difference of only 4 feet in the iotal thickness of the Upper Coal Measures as given by Prof. Brown's section at Bellaire and mine at Wheeling, four miles above. 


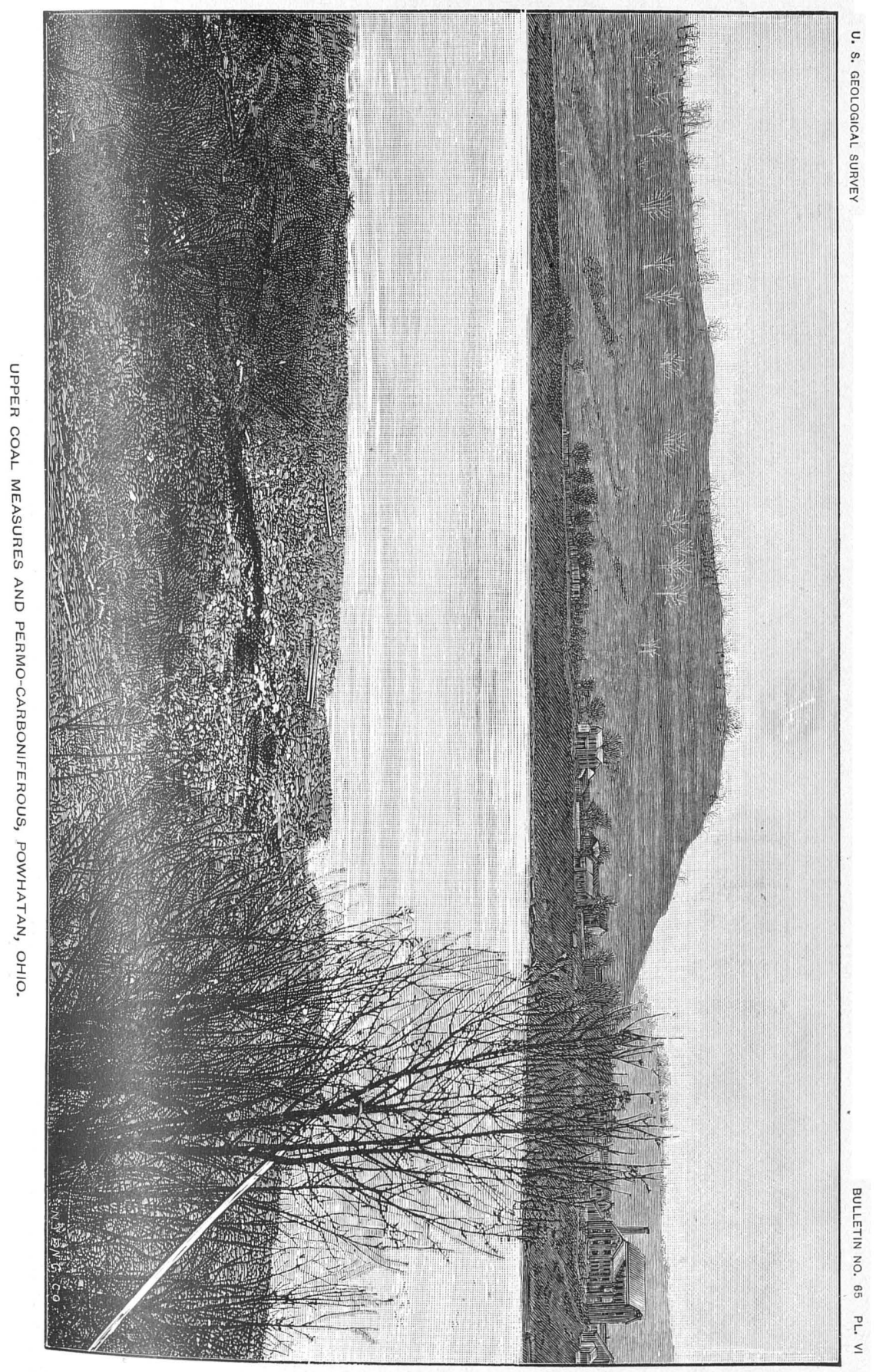



Section at Moundsville, West Virginia.-Near the mouth of Grave Creek, one mile below Moundsville, West Virginia, and 7 miles below Bellaire, these measures exhibit the following succession by combining the surface exposures with the record of an oil boring (Fig. 21):

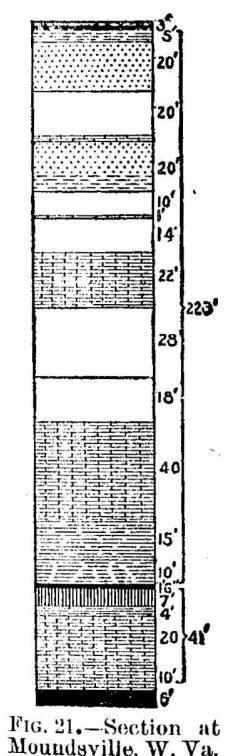

Moundsville, Marshall County, West Virginia.

[Soo map, K i.]

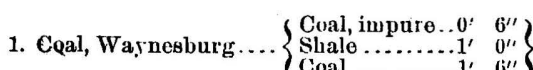

2. Shale, soft, gray ..................................

3. Saudstone, wassive, gray, micaceous ................. 20

4. Concealed, with limestono layer's at base 2 foet thick.... 20

5. Flagry sandstone and saudy shales ................ 20

6. Coucealed ................................... 10

7. Limestone........................................ 1

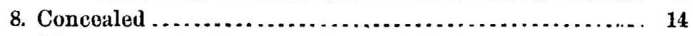

9. Limestone, gray .................................... 22

10. Concealed to mouth of oil and gas well at 30 feet above low.water mark in Obio River . . ................... 28

11. Conductor holo of oil-woll record $\ldots \ldots \ldots \ldots \ldots \ldots \ldots \ldots, 18$

12. Limestone, light gray .......................... 40

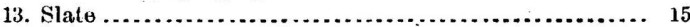

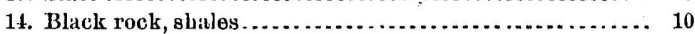

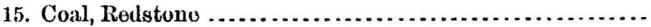

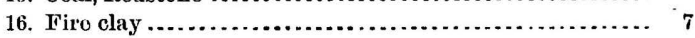

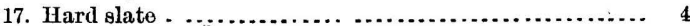

18. Gray limestone................................ 20

19. Bastard limestone.............................. 10

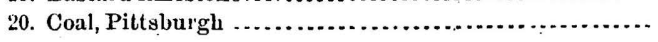

Total
Fit. in. Ft. in.

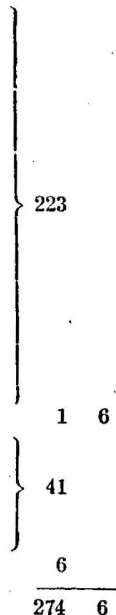

Section on Pipe Creek, Ohio.-Pipe Creek puts into the Ohio River 3 miles below the mouth of Grave Creek, and there, on the Belmont County side of the river, the Pittsburgh coal is at low-water level. The following structure (Fig. 22) is found in the steep hills which border the mouth of Pipe Creek :

Pipe Creek, Belmont County, Ohio.

[See map, K i.]

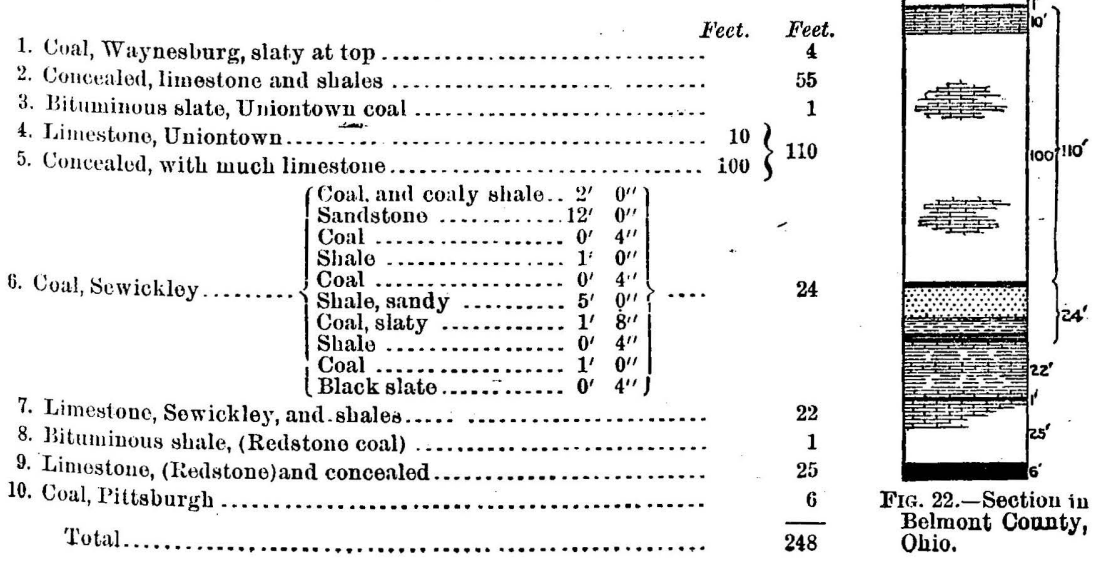


Below this last locality no measurement of the Upper Coal Measure series is possible for a long distance, because most of the members are below water level. They are all brought to the surface, however, by the Volcano anticline, which crosses the Ohio River from Pleasants County, West Virginia, into Washington County, Ohio.

Section in Washington County, Ohio.-Mr. F. W. Minsball, of Marietta, (H)io, has made a very careful study of these measures in Washington County, Ohio, and has prepared the following section (Fig. 23) as representing their usual structure there:

Washingtom County, Ohio.

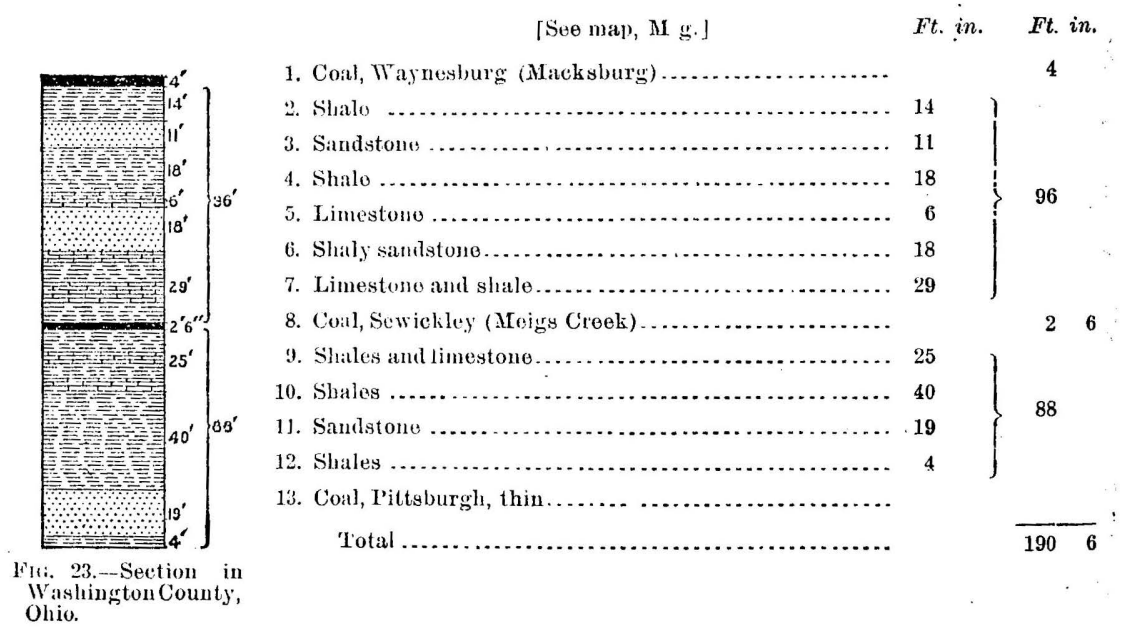

The thickness here given is 50 to 60 feet less for the entire series than that usually found in any other portion of the Appalachian field.

Section at Burning Springs, West Virginia.-In the vieinity of Burning Springs, Wirt County, West Virginia, these rocks are brought above the surface by the same anticline, and there Mr. Minshall reports the following structure (Fig. 24) :

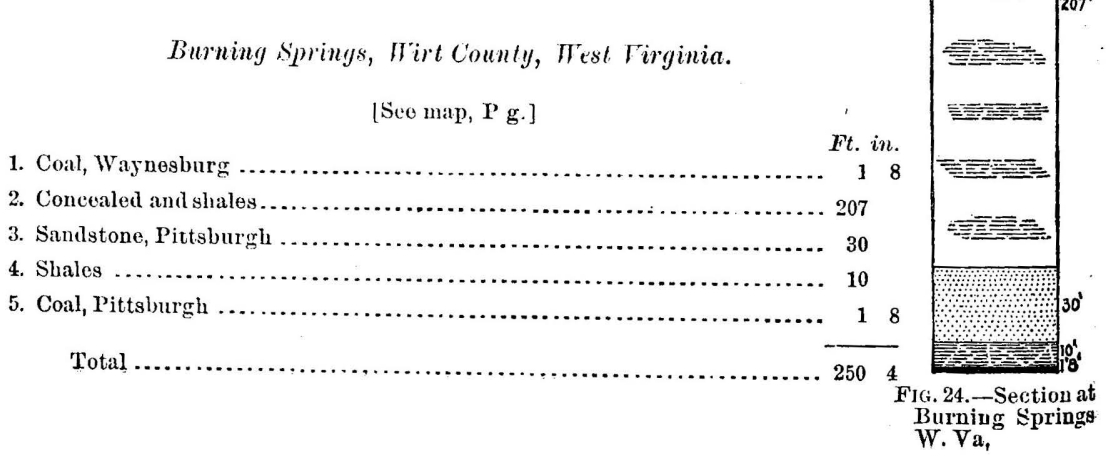


Both here and all along the Volcano anticline the Pittsburgh coal is very poorly developed, as shown in this and the previous section, and it is frequently absent entirely.

Section on Leading Creek, West Virginia.-Near Leading Creek postoffice, at the eastern edge of Gilmer County, West Virginia, this series shows thus (Fig. 25):

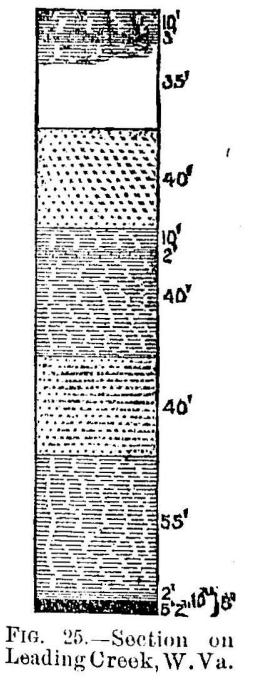
Leading Creek, Gilmer County, West Virginia.

[See map, $\mathbf{P}$ j.]

1. Waynesburg coal horizon (absent).

2. Shales

3. Limestone, brecciated

4. Shales and concealed ....................................... 35

5. Sandstone, yellow, massire, soft, pebbly .................... $\quad 40$

6. Shales ................................................. 10

7. Limestone, impure....................................... 2

8. Shales ................................................. 40

9. Sandstone, massive ......................................, 40

10. Shales ................................................. $\quad 55$

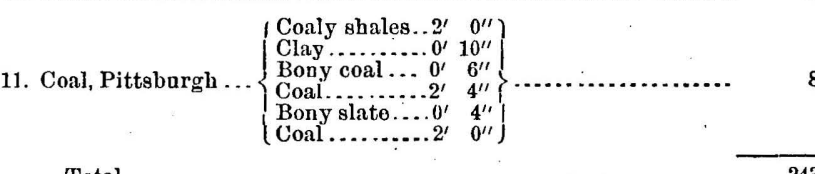

Section at Antiquity, Ohio.-Along the Ohio River, below where the Volcano arch crosses, the Upper Coal Measures again plunge under water level, and do not emerge again till we come to the vicinity of Antiquity, Meigs County, Ohio, 100 miles below. A shaft to the Pittsburgh bed (130 feet under river level), taken in connection with the surface exposures there, reveals the following succession (Fig. 26):

\section{Antiquity, Meigs County, Ohio.}
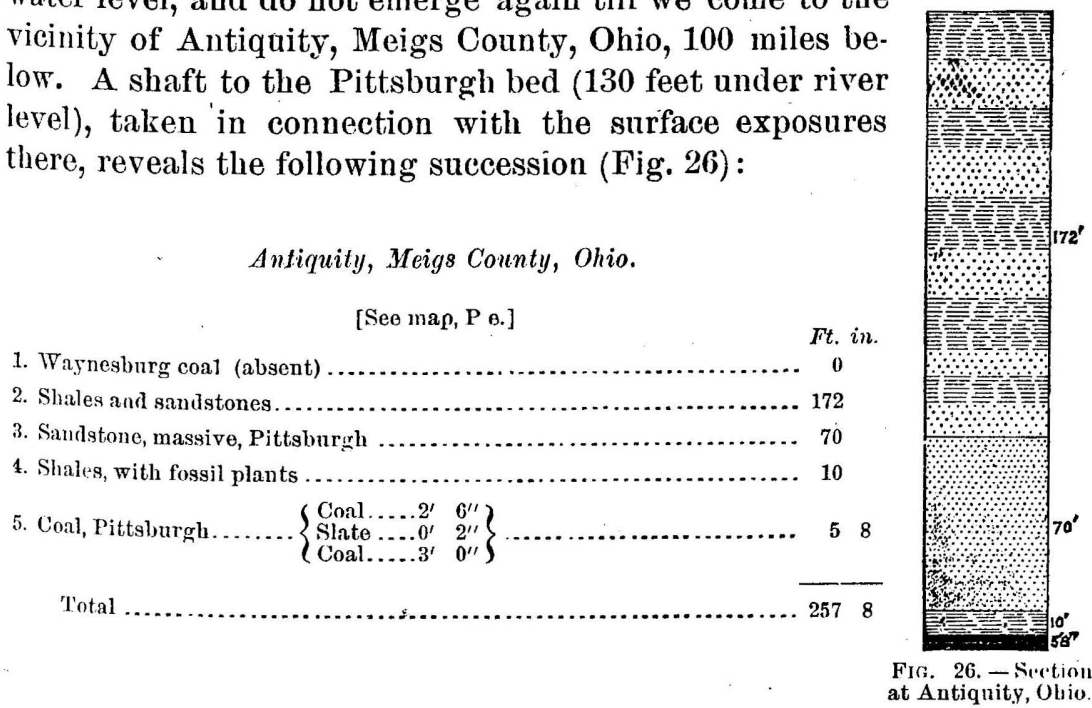

Section at Hartford City, West Virginia.-Six miles below the shaft at Antiquity, and in the vicinity of Hartford City, the Pittsburgh coal 
comes abore water level. In the steep bluffs above Hartford the following succession (Fig. 27) was observed :

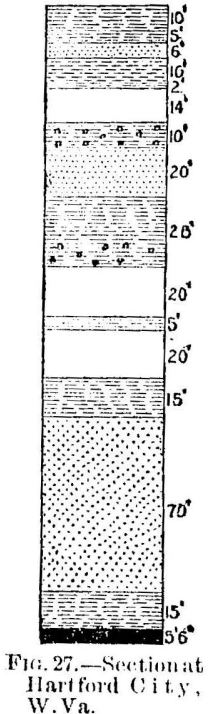

\section{Hartford City, Mason County, Mest Firginia.}

[See map, $\mathbf{P}$ d.]

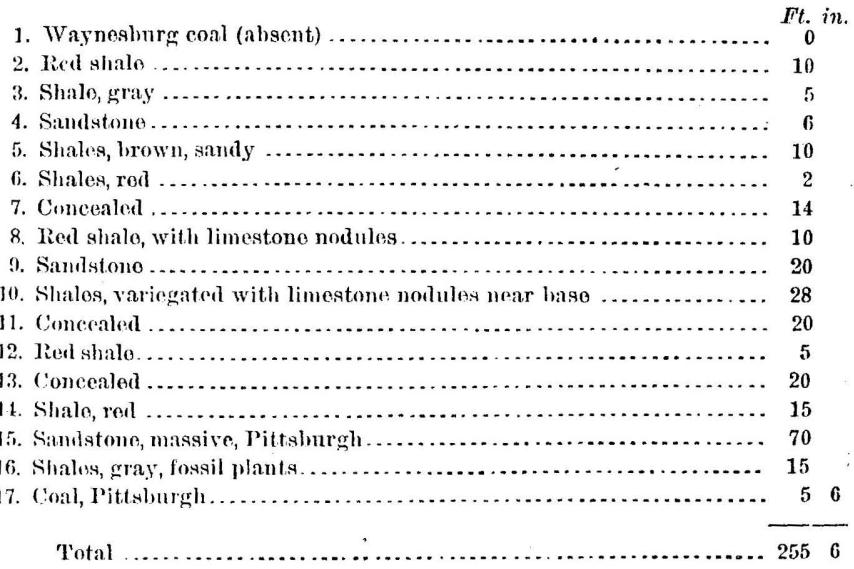

Section at Arluckle, West Virginia.-In the vicinity of Arbnckle, Mason County, West Virginia, on the Great Kanawha River, and 18 miles above its mouth, the Waynesburg coal makes its appearance in the section. IIere the following structure (Fig. 28) was obtained for the series, by combining the surface exposures with the record of a boring made by Mr. Craig:

Arbuclie, Mason County, West Tirginia.

[Son map, Q o.]

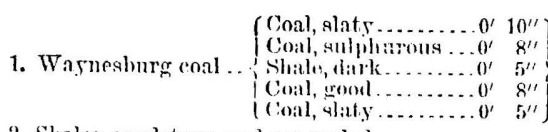

2. Shales, sandstone, amd comcealıd.

3. Siandstone, hlue

4. Silialos, real.

5. Samdefone, hlue, hard

6. Variegratiod shiales.

7. Conl, Surickloy

8. Sandstone.

9. Shates, red.

10. Shales, variegatod

11. Fire clay, impure (Redstone eal)

12. Simulstone, coarse, white, Pittshurgh

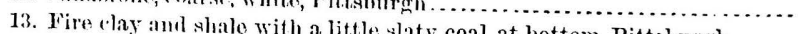
Total

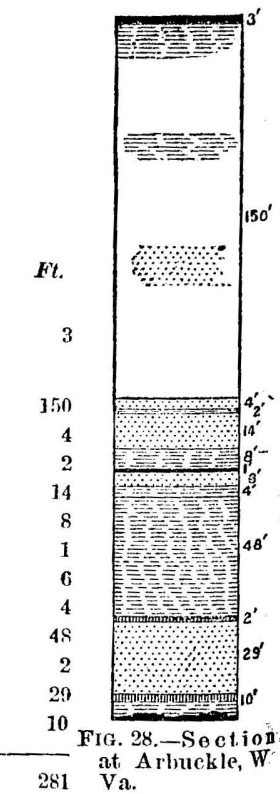

Here there is practically no merchantable coal in the whole series, since the Waynesburg bed, although 3 feet thick, is poor and slaty 
The locality is near the center of the deepest portion of the Appalachian . trough, and the horizon of the Pittsburgh coal is 90 feet under the Kanawha. $A$ hole was drilled as a test for this coal, but the resnit proved only a trace of it present.

Section at mouth of Big Hurricane Creek, Putnam County, West Virginia.-Sonthward up the Kanawba River from Arbuckle, the locality of Section 28, the rocks rise and the entire series comes above water level at the mouth of Big Hurricane Oreek, in Putnam County. Here,

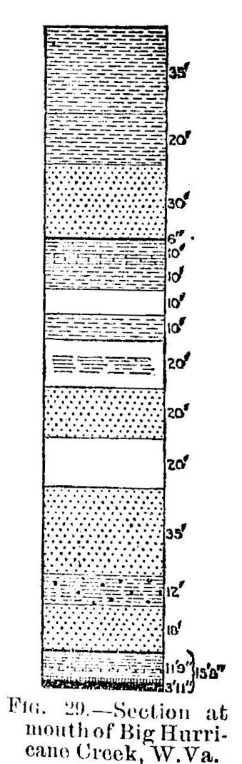
32 miles from the mouth of the Big Kanawha, the following succession may be seen (Fig. 29):

Mouth of Big Hurricane Creek, Putnam County, . West Virginia. [See map, $\mathbf{R}$ d.]

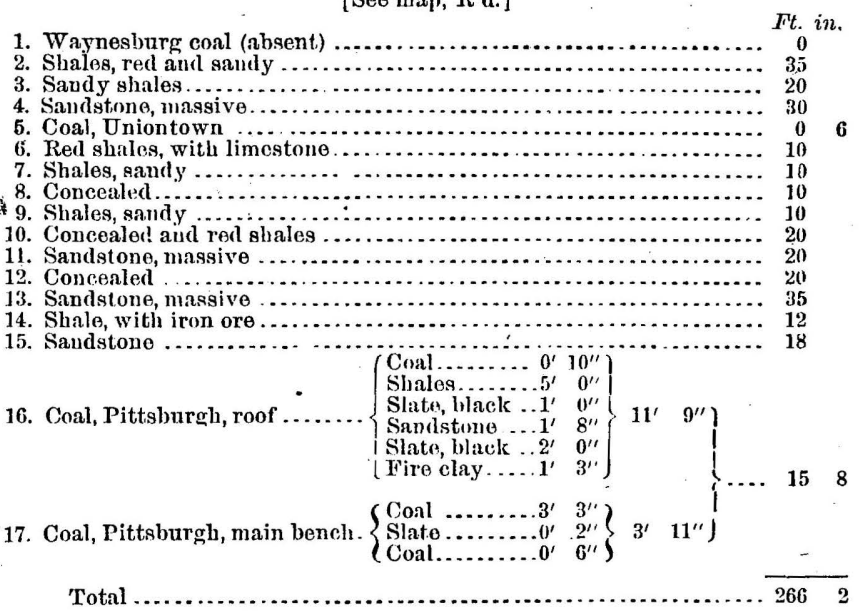

The Pittshurgh coal is patchy all throngh this region, being workable on some farms and absent on others.

Section opposite Winfield, West Virginia.-As showing the nureliable character of the coals in this series along this portion of the Kanawha, the section (Fig. 30) of the rocks opposite Winfield, Putnam County, 5 miles above Big Hurricane, is given :

Opposite Winfield, Putnam Counly, West Firginia. [See map, $\mathrm{S} \cap$.]

1. Waynosburg coal (absent)

2. Shates, red, with limestono nodules.

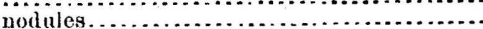

4. Concealed .

5. Reril shate

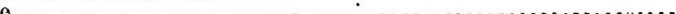

t. Sindstome, flaqey

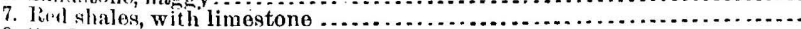

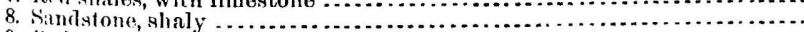

9. livd stale

10. Simlstone, shaly

11. Rivl shales

Y

13. Coneraled

14. Risl shale, with limestcme modnles mear base.

15. Simelvtomes, reel, aml gray shales

16. Jire clay, flace for Pittiburgh coal . Total

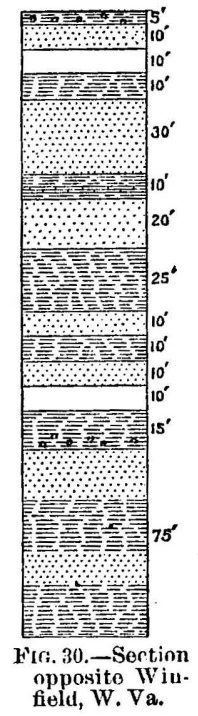


This section was measured in the steep hill at Red Honse Station, on the Kanawha and Ohio Railroad, and, as may be seen, the series does not there contain any coal whatever.

Section near Raymond City, West Virginia._Further up the Kanawha

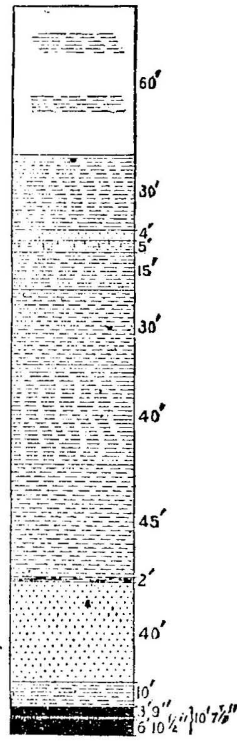

Fic. 31. - Section near Raymond City, W. Va. the Pittsburgh coal again comes in, and the follow. ing structure (Fig. 31) is found in the vicinity of Raymond City, 6 miles above Winfield:

Near Raymonal City, Putnam County, West Virginia.

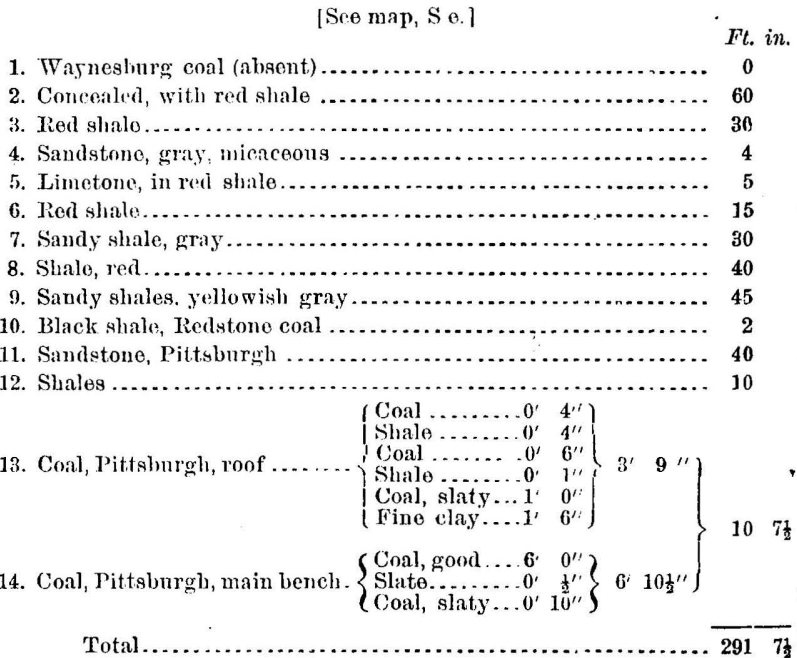

Section in vicinity of Western Port, Maryland.-In the Cumberland or Georges Creek basin, the Upper Coal Measures exhibit the following strueture (Fig. 32), as observed in the vicinity of Western Port, Maryland:

Ticinity of Western Port, Alleghany Connty, Maryland.

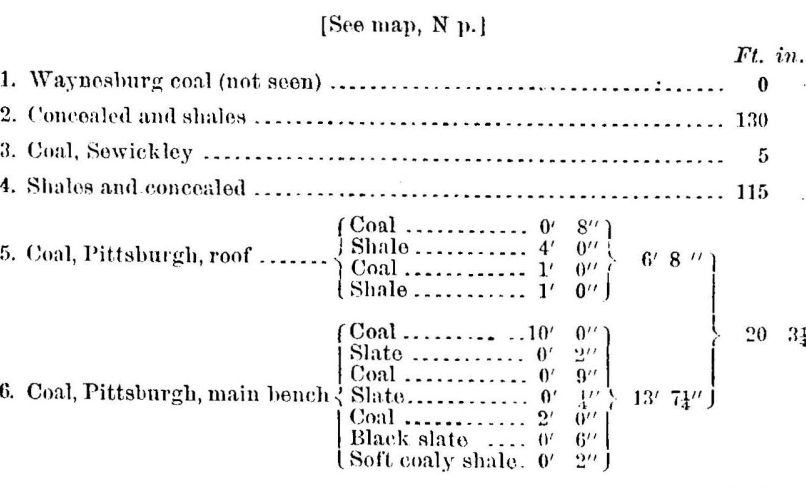

Total

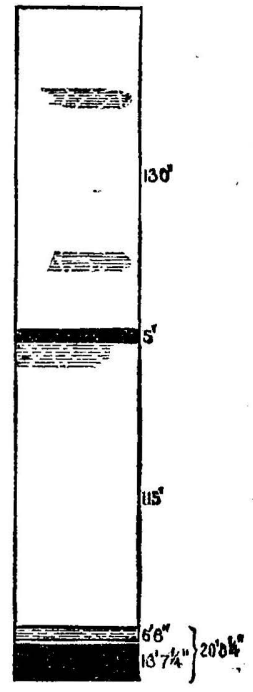

Fig. 32. - Sectiou near Western Port, Md. 
From the foregoing sections it will be perceived that the beds in the Upper Coal Measures which have received distinct names are in descending order as follows:

\author{
Waynesburg coal. \\ Browntown sandstone. \\ Little Waynesburg coal. \\ Waynesburg limestone. \\ Uniontown sandstone. \\ Uniontown coal. \\ Uniontown limestone. \\ Great limestone.
}

\author{
Sewickley sandstone. \\ Sewickley coal. \\ Sewickley limestone. \\ Redstone coal. \\ Redstone limestone. \\ Pittsburgh sandstone. \\ Pittsburgh coal.
}

These several beds we shall now notice more in detail.

CHARACTERISTIC HORIZONS.

THE WAYNESIBURG COAL.

This, the highest member of the series, is generally quite persistent around the northern end of the coal field, but followed southward through West Virginia it soon becomes patchy and interrupted, so that beyond the line of Marion County the coal is only occasionally present along the eastern and central portions of the Upper Coal Measure belt, its horizon being frequently occupied, as at Harrisville, Ritchie County, by a brecciated limestone.

On the Great Kanawha this coal occurs near the center of the Appalachian trough over a small area in the vicinity of Arbuckle, and its structure there is given in Section 28.

Along the western side of the field, down the Ohio River and across sonthern Ohio, this coal is fairly persistent. It dips under the Ohio River at New Martinsville, but rises to daylight again near St. Mary's, where it is only 1 to 3 feet thick, and quite sulphurous.

In the Macksburg oil region it is the principal bed, according to the Ohio geologists, and has a thickness of 4 feet.

This coal is almost universally double, being separated into two layers by a division of shale and slate. This is so common at the northern end of the field that it is known there as the "horse-back" vein. In Monongalia and Greene Counties the bed is often 8 to 10 feet thick and separated into three layers, the upper division of slate being very fossiliferous, and often, as at Cassville, West Virginia, containing many insect remains, together with fossil plants.

The coal from this bed is usually rather hard, and comes out in large blocks; but it frequently contains injurious quantities of sulphur. This renders it unfit for smithing, as well as for the manufacture of coke and gas, but it is generally a useful fuel for steam and domestic purposes.

IRON ORE.

The shales which underlie the Waynesburg coal sometimes contain a considerable quantity of iron nodules, and they were once mined in 
Morgan Township, Greene County, Pennsylvania, and used in manufacturing iron. The same ore occurs near Bethel Church, Cass District, Monongalia County, at 15 to 20 feet below the coal.

THE BROWNTOWN SANDSTONE.

In many portions of Marion and Harrison Counties, West Virginia, the interval beginning 5 to 10 feet below the Waynesburg coal is occupied by a hard, gray, massive sandstone, 20 to 35 feet thick. It is finely exposed along the bed and bluff's of Ten Mile Creek, at and below Browntown, Harrison County, West Virginia, and has been designated from that locality. The deep, rocky cuts along the Baltimore and Ohio Railroad, beginning 1 mile east of Mannington, Marion County, and extending to the month of Mod's Run, are all in this sandstone. It is sometimes called the "Gilboy" sandstone, from a rocky cut of that name near Mamington. This is nearly always a water-bearing stratum, and the oil wells of Marion County have to be cased below this rock in order to shut off the fresh water.

THE IITTLE WAYNESBURG COAL.

At many localities around the northern end of the Upper Coal Measure area a thin streak of coal or bituminous slate occurs at 25 to 40 feet below the Waynesburg coal, and it was termed the Little Waynesburg coal by Prof. Stevenson. It seldom exceeds 1 foot in thickness, and is of no economic importance. It is usually separated from the main coal above by shales and sandy beds, and should probably be regarded as an offishoot from the Waynesburg coal proper. It is seldom seen south from the Pennsylvania line, though it occurs along the Ohio River at several places.

THE WATNESBURG LIMESTONE.

Directly under the last described stratum there occurs a limestone of very wide distribution. Its place is generalty about $\mathbf{4 0}$ feet below the Waynesburg coal, thongh sometimes it is less, and occasionally a few feet more. It is nstally of a dark gray color, and several of the layers make excellent lime for agricnltural and building purposes. The thickness in Pennsylvania and northern West Virginia is seldom less than 8 feet, and frequently donble that, but sonthwestward, toward the Great Kanawha region, the limestone disappears entirely.

TIIE UNIONTOWN SANDSTONE.

At 60 to 75 feet below the top of the series there frequently occurs a massive, gray sandstone whose horizon comes immediately above the Uniontown coal; and hence, althongh the stratum in question is not prominent at Uniontown, it has been designated from its relations to. the underlying coal.

The rock has occasionally been mistaken for the Waynesburg sandstone, which belongs nearly 100 feet above. It is well exposed at Bob- 
town, Greene County, Pennsylvania, where it crowns the summit of the hill overlooking Dunkard Creek as a bold cliff.

In the Georges Creek coal field a massive sandstone occurs 250 feet above the Pittsburgh coal, and it was once referred by the writer to the Uniontown horizon under the name of "Westernport sandstone," but subsequent study seems to place it in the horizon of the Waynesburg sandstone.

THE UNIONTOWN COAL.

This bed underlies the Waynesburg coal by an interval of 80 to 100 feet, and is of economic importance only in Fayette and Washington Comnties, Pennsylvania. It was named by Rogers from Uniontown, Fayette County, where it is well exposed. The thickness seldom exceeds 3 feet, even in the region of its best development, and the coal has never been used except for domestic purposes, since it is usually neglected for the great Pittsburgh bed below. It often contains a clay or slate parting near the center, 4 to 6 inches thick, and is rather too rich in ash for a first-class fuel.

Sonthward from Fayette County, through Greene, Monongalia, Marion, and Harrison, this coal thins away to a bed of black slate mixed with slaty coal that is often rich in fish remains and bivalve crustaceans, which may be found in abundance near Davistown, Greene County, Pennsylvania.

Along the Ohio River at Wheeling, Bellaire, Clarington, and other points, this bed is sometimes represented by a thin streak of black slate or coal. In the Salisbury basin of Pennsylvania it is recognized by Messrs. Platt, and is there over 3 feet thick, with state near center.

$$
\text { THE UNIONTOWN LIMISTONE. }
$$

To the division of the "Great" Limestone which immediately underlies the last described coal bed, Dr. Stevenson gave the name Uniontown, since it seems to be fairly well separated from the great mass of limy deposits below. This division is usually 10 to 15 feet thick, though occasionally it surpasses these figures. The rock is frequently impure and of a buffish color, being magnesian, and occasionally a good cement rock, as at Uniontown, Pennsylvania. This is the only member of the "Great" Limestone which appears to be persistent from the Pennsylvania line southward across West Virginia to the Big Kanawha River, since an impure limestone only 2 to 5 feet thick occurs at this horizon in the vicinity of Raymond City and other points in that region.

In the Salisbury basin this limestone occurs only 160 feet above the Pittsburgh coal, and is $\mathbf{1 0}$ to 12 feet thick, according to Platt.

THE "GREAT" LIMESTONE.

This name, given by Rogers, is generally applied to all of the great mass of lime deposits which intervene-between the Uniontown and Sewickley coals, though, as already stated, the name Uniontown is now given to the uppermost dirision of the same. 
At many localities in Greene, Washington, Fayette, and Monongalia Counties there are nearly 160 feet of limestones and limy shales at this horizon, and the same beds hold their place, though with diminished thickness, across to the Ohio River at Wheeling. Westward and south. ward, however, from Ohio and Marion Counties, these limestones disappear very rapidly, so that at Clarksburg on the one hand, and westward throngh Ohio on the other, they have practically disappeared, and in their stead we find shales, gray at first, but gradually getting reddish toward the Little Kanawha River and the western margin of their outcrop in Ohio. On the Big Kanawha much red shale occurs at this horizon. These limestones are of difierent qualities, some of the layers being quite pure and forming good fluxes for iron, while others are magnesian and make excellent hydraulic cements.

The only fossils ever seen in any of these limestone beds are fish remains and minute ostracoids.

THE SEWICKLEY SANDSTONE.

At many localities where the "Great" Limestone is "well developed there are no other beds except limestones and shales in all of the interval between the Uniontown and Sewickley coals, but in other regions a sandstone frequently makes its appearance just above the Sewickley coal. This has been called the Sewickley sandstone, and while it is often flaggy, yet again it becomes massive, and even pebbly, varying in thickness from 20 to 60 feet. Its massive character is well shown along the Monongahela River between Morgantown and Fairmont, in the vicinity of the Big Falls.

TIIE SEWICKLEY COAL.

Directly under the Sewickley sandstone, or in its absence the "Great" Limestone, there comes the Sewickley coal, a bed which is widely persistent, though the area where it is valuable is not so large.

The bed attains its maximum thickness and importance along the Monongahela River in Greene, Monongalia, and Marion Counties, being there 5 to 6 feet thick, with only one slate parting of 2 to 3 inches near the center. The coal is generally high in both ash and sulphur, but is open-burning and makes a rather fair domestic fuel.

The following represents the general structure of this bed along the Monongahela River in Marion and Monongalia Counties:

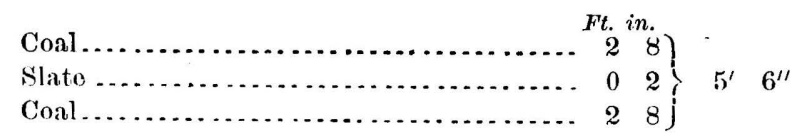

Followed down the Monongahela River, the bed retains about the same structure as far as the mouth of Whitely Creek, Greene County, Pepunsylvania, when the slate partings thicken up, and new ones come in and dissipate the coal in several thin layers through 25 feet of rock 


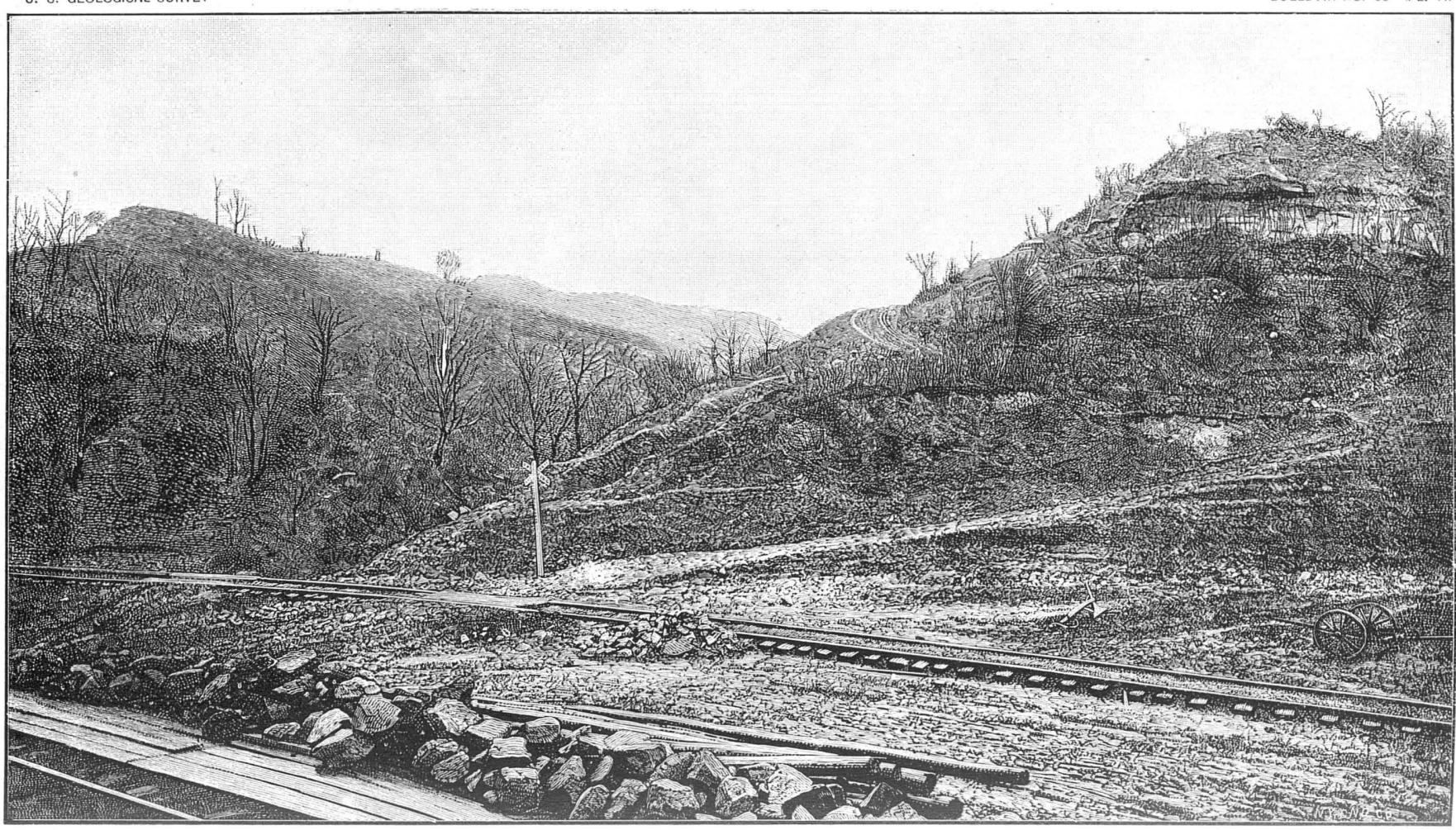

UPPER COAL MEASURES AT POINT PLEASANT, WEST VIRGINIA, SHOWING RUGGED CHARACTER OF THE T_...GRAPHY. 

material, and from thence on down that river it is of no importance. But followed in the other direction, up the Monongahela, this bed holds a thickness of 5 to 6 feet through Marion County until the Harrison County line is approached, when it again splits up into three or four divisions separated by several feet of shales and slates, and when Clarksburg is reached there remains only 1 foot of coal at this horizon (Section 18), which soon disappears entirely toward the southwest.

From the Monongahela region this coal dips down westward under the great mantle of Permo-Carboniferous beds, and when it reappears on the Ohio River, in the vicinity of Wheeling (Section 19), Bellaire (Section 20), and Pipe Creek (Section 22), we find it split up again into three or four layers, and the separating slates several feet thick, thus giving the whole bed a thicknesss of 20 to $30 \mathrm{feet}$, with the main coal layer at the top.

This uppermost division of the Sewickley is separated from the Pittsburgh below by an interval of 80 to 100 feet, and attains considerable importance in the counties of Belmont, Harrison, Guernsey, Monroe, Morgan, Muskingum, Noble, etc., and has there been mined under a variety of names, among which are " Upper Barnesville," "Upper Bellaire," "Cumberland," "Meigs Creek," and several others. Prof. Orton, while intimating its identity with the Sewickley of Pennsylvania (Vol. V, page 1059, Ohio Geology), prefers to call it by the name of Meigs Creek, from a stream in Morgan County. along which it is well developed.

Throughout much of this Ohio region the coal is 3 to $4 \frac{1}{2}$ feet thick, and nearly always has a clay or bony streak near its center. It also frequently has a rider coal in the roof, and the entire bed is rather rich in ash and sulphur, according to Orton.

In Fayette County, Pennsylvania, the Sewickley coal has a thickness of 4 to 5 feet through several townships, according to Stevenson, but northward through Westmoreland it thins down and is unimportant. It is scarcely known in the Ligonier basin, but in that of Salisbury is 2 feet thick and 90 feet above the Pittsburgh.

In the Georges Creek basin of Maryland and West Virginia the bed is 5 to 7 feet thick, 90 to 115 feet above the Pittsburgh, and an excellent coal for steam purposes.

The oil-borings across Monongalia and Marion Counties reveal this coal present in good thickrress 10 to 15 miles west from the Monongahela River, and 100 to 110 feet above the Pittsburgh coal. The oil drillers usually call it the "Mapletown" coal, from a locality in Greene County where it is mined.

THE SEWICKLEY LIMESTONE.

The interval between the Sewickley coal and the one next below is often occupied largely by limestone, especially in Greene, Fayette, Washington, Monongalia, and Marion Counties, and to the one which 
comes next helow the coal Messrs. Platt have given the name Se wickley. It has also been termerl the Fishpot Limestone by Ste venson, from a small stream in Washington County. I have deemed it preierable to apply the name Sewickley to the whole limestone gronp which lies between the Sewickley and Redstone coal beds. This inter. $\mathrm{val}$ is 40 to 60 feet thick and sometimes contains two beds of sandstone intercalated with the limestones. Along the Monongahela River in Greene, Monongalia, and Marion Counties, these limestones are well developed, and many of the libyers furnish excellent lime for mortar and agricultural uses, while near the base of the group occur some excellent limestone flags at Lanurel Point, Monougalia County.

The only fossils ever noted in these beds are minute fresh-water types.

These limestones disappear southward from IIarrison County, West Virginia, there being only 9 feet of them in the Clarksburg section, aud none on the Little and Bigr Kanawha Rivers. The same thing takes place in Ohio, westward from Washington Connty, the interval beiug occupied by shales and sindstones.

In Pemsylvania this Sewickley limestone holds a prominent place eastward from IVashington and Greone, through Fayette, Westmoreland, and somerset Counties.

\section{THLE LEDSTONE CUAL.}

In Fayetle County, lenmsylvania, a small coal was found cropping out along Redstone Creek, at an interval of 40 to 45 feet above the. l'ittshmigh, and this was mamed from that stream by the geologists of' the Finst Pemsylvania Geological Survey.

Monongalia is the only connty in West Virginia where this bed is workable, it bemg there, on Scott's and Robinson's liuns, 4 to 5 feet thick and of fair cuality, thongh having rather too much sulphur and ash for manulacturing purposes. It is also workable in several townships of Fayette and Westmoreland, being 3 to 4 feet thick. In the Silisbury basin of Somerset County, Messiss. P'att identify the Redstome coat ats a slaty bed, 4 feet thick, at 45 feet abore the Pittsburgh. It has not been reliably reported from the Georges Creok field anless it be represented by one of the rider layers in the roof of the Pitts. burght beed.

In the vienity of Wheeling, Bellaire, and other points on the Ohio liver, this bed is only a few inches thick, never becoming workable athy where in Ohio.

'Through central West Virginia, beyond the Little Kanawha, its presence is unknown except by a bed of black slate, which is occasionally seen at this horizon.

THE REDSTONE LIMESTONE.

At many localities along the Monongahela River in Harrison, Marion, Monongalia, Greene, Washington, Fayette, and Westmoreland Counties, there oceurs a bed of limestone often 10 to 20 feet thick, and im- 
mediately uuderlying the Redstone coal. From this latter fact jt was termed the Redstone limestone by Messrs. Platt, who find the same bed in Somerset County, 40 to 45 feet above the Pittsburgh coal. It often contains several layers, which make fairly good lime for many purposes, and is occasionally used for flux in iron furuaces.

This limestone is also in great force in the vicinity of Whecling, Be]laire, and vicinity, where it occupies nearly the entire interval between the Relstone and Pittsburgh coals, and is extensively quarried as a flux for the furnaces there.

It, like all the other limestones, disappears southwestward through West Virginia, and is not known beyond the Little Kanawha River.

THE PITTSBURGH SANDSTONE.

Very frequently, and especially when the Redstone limestone is well developed, there is nothing but shales intervoning between it and the Pittsburgh coal, but when the limestone is absent, or but poorly represented, there is often present a coarse, massive saudstone immediately above the Pittsburgh coal, and to this Mr. H. D. Rogers long ago gave the name of Pittsburgh sandstone. It varies in thickness from 25 up to 70 feet, and is usually coarse, friable, and often pebbly. Good building stone has never been obtained from it, since it yields so readily to atmospheric agencies.

This rock is especially massive in the vicinity of Hartford City, Pomeroy, and other contiguous regions, and the same may be said of the eastern line of its outcrop from Peunsylvania clear across West Virginia to the Kentucky border.

In the Georges Creek, Salisbury, and Ligonier basins, however, this rock makes but little show in the topography, its place being occupied by soft shales.

THE PITTSBURGH COAL.

The last and lowest member of the Upper Coal Measures is the celebrated Pittsburgh bed, the most important mineral deposit of the Appalachian field.

It was formerly thought that this coal bed was entirely persistent; that wherever its horizon was to be found, there the coal might be expected with absolute certainty. This generalization, however, was founded on data obtained only from the northern half of its area. In Peunsylvania, for instance, no area has yet been discovered where, at the proper geological horizon for this bed, it does not exist. Even in central Cireene, at a depth of 1,500 feet below the Permo-Carboniferous summits, the drill of the petroleum seeker invariably tiuds this coal bed, while the isolated peak of Round Top, in the Broad Top coal basin of Bedford County, 50 miles distant from any other outcrop of the coal, likewise contains it. But when we pass southwestward across the West Virginia and Ohio coal field, Pennsylvania conditions of course continue 
for many miles, but ultimately there comes a change, and when we look for the Pittsburgh bed it is gone, or so reduced in thickness that the geologist can only recognize it by its associated rocks. The region of country covered by this barren area is quite extensive, and seems to be rudely coincident with the line of the Volcano or Burning Springs anticlinal of West Virgiuia.

The following counties in that State have the coal but poorly developed or wanting at the horizon where it belongs: Calhoun, Roane, Wirt, Ritchie, Pleasants, and Wood. This belt projected northward through Ohio takes in the counties of Washington, Noble, and Mor. gan, in all of which the coal is thin or wanting altogether. Thus it happeus that over a belt of country 30 to 50 miles wide, and running nearly north and south across the Appalachian coal field, the spread of this bed, so even and persistent at the north, is here irregular, interrupted, and wanting. West from this belt the coal comes in again and is fairly regular in parts of Kanawha, Putuam, and Mason Counties, east from the Big Kinnawha but west from that stream the bed is thin, patchy, and of little importance through Cabell and Wayne, till it disappears from the center of the great Appalachian trough in the hilltops overlooking the Big' Sandy River.

In Ohio, also, a considerable area of this coal comes in west from the barren belt, and extends through Meigs and Athens Counties with fairly good thickness, but westward from them, in Gallia, the coal is again thin and uncertain.

The foregoing sections, Nos. 11 to 32 inclusive, show in a general way the detailed structure of the Pittsburgh coal, so that only a fow others need be given in this connection to exhibit its structure in every important region of its widely extended area.

As will be seen from these sections, the coal is nearly always separated into two well defined portions (the roof and the main bench) by a layer of clay, and there are often several divisions of the roof, as also of the main bench. The layers of coal in the roof are usually not more than 1 to $1 \frac{1}{2}$ feet thick, and separated by shales of about the same thickness, while the divisions of slate in the main bench are mere knife edges, seldom exceeding an inch in thickness and generally not more than half that amount.

Along the Monongahela River, two of these slates are especially con. stant, since they come about $2 \frac{1}{2}$ to 3 feet above the bottom of the bed and are 4 to 6 inches apart. They are usually known as the "bearing in" slates, and are seldom more than one-half inch thick. Then 1 to $1 \frac{1}{2}$ feet below these there is generally another thin parting of slate which runs through the bed with great persistency, dividing the lower portion into two layers known by the miners as the "brick" coal, and "bottom" coal. Of course there are other partings which occasionally make their appearance in the bed at some localities, but they are irregular and not persistent. 
U. S. GEOLOGICAL SURVEY

BúLLLĖTiN No. 65 PL. Viii

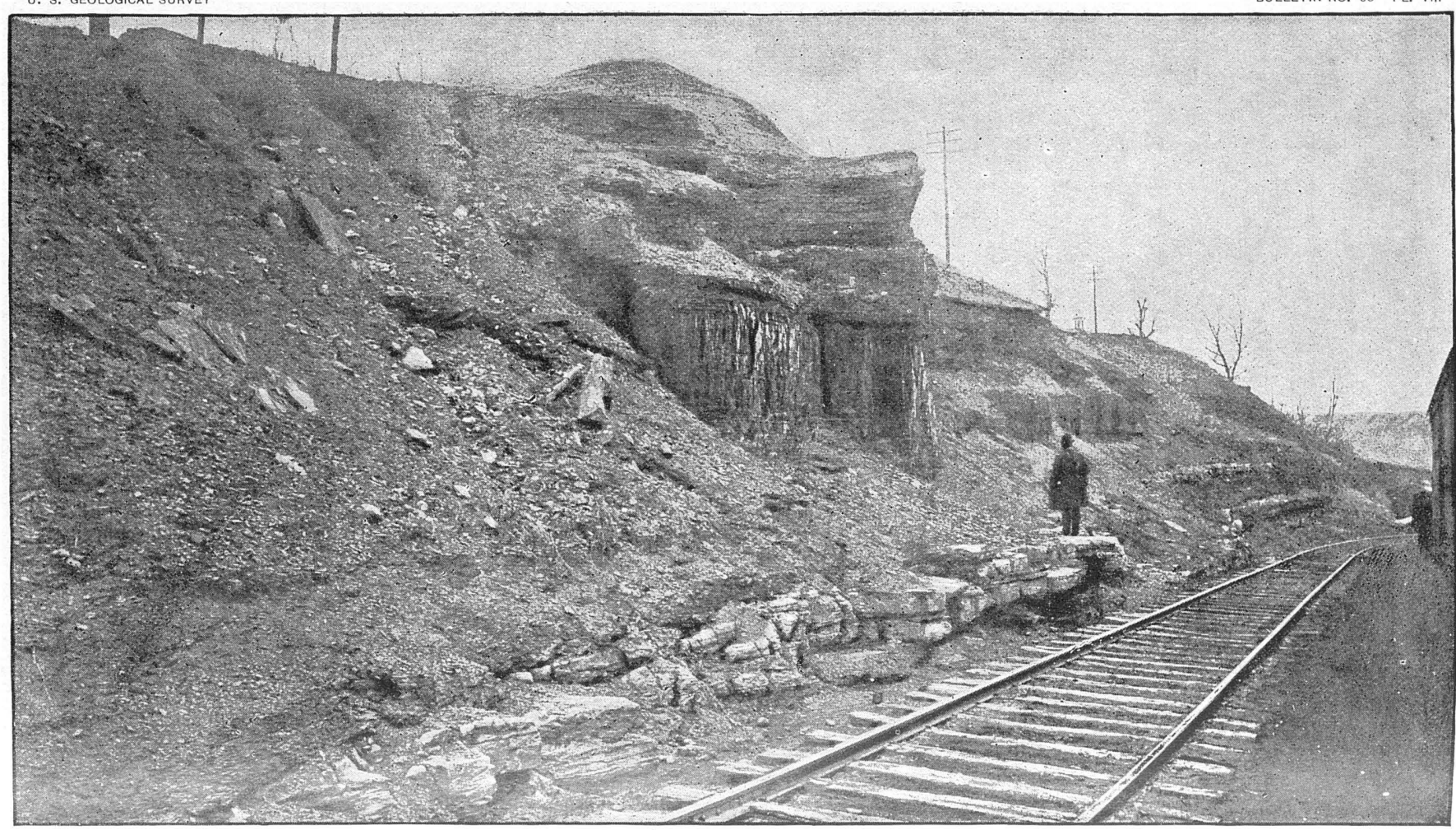

THE PITTSBURG COAL OUTCROP NEAR CONNELLSVILLE, PENNSYLVANIA, SHOWING COLUMNAR STRUCTURE OF TYPICAL COKING COAL. 

Section at Neuburg, West Virginia.-The summits arouni Newburg, Preston County, West Virginia, catch small areas of this bed in the syneline between the Chestnut Ridge and Laurel Hill anticlinals, and the coal has there the following structure :

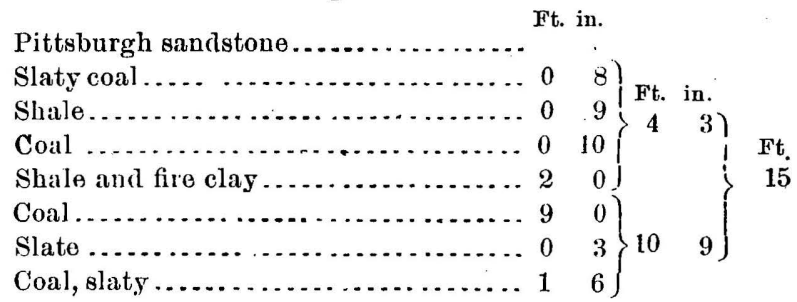

Section at Copeman's Knob, West Virginia.-In the next trough east of the Laural Hill anticlinal, a small isolated area of the Pittsburgh coal is caught in Copeman's Knob, which overlooks Cheat River at the foot of Briery Mountain, near Albrightsville, Preston County, West Virginia, and there the coal shows this structure:

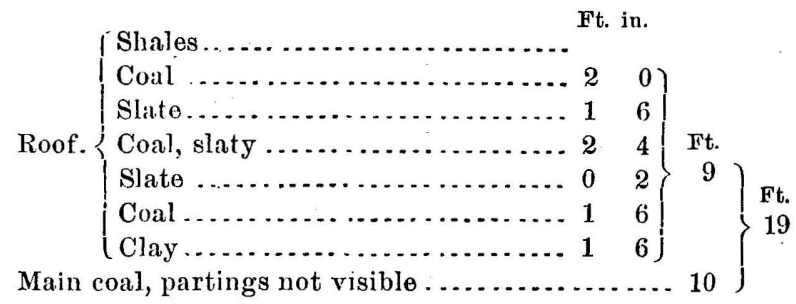

Section 32 gives the structure of this coal still farther eastward in the Georges Creek basin, and it, when compared with the Albright, Newburg, and Fairmont (Sec. 17) structures, shows a gradual eastward thickening of the bed from 7 feet on the Monongahela to 20 at many points in the Georges Creek field.

Section at Fairfax Knob, Tucker County, West Virginia.-Near the sonthern end of the Georges Creek basin, at the head of the North Potomac River, a small area of the Pittsburgh bed is caught in the summit of Fairfax Knob, 3,250 feet above tide, and 20 miles distant from any other outcrop of the coal. The main portion of the bed is here split into three portions, separated by several feet of shales, from the thickening up of the parting slates, as follows:

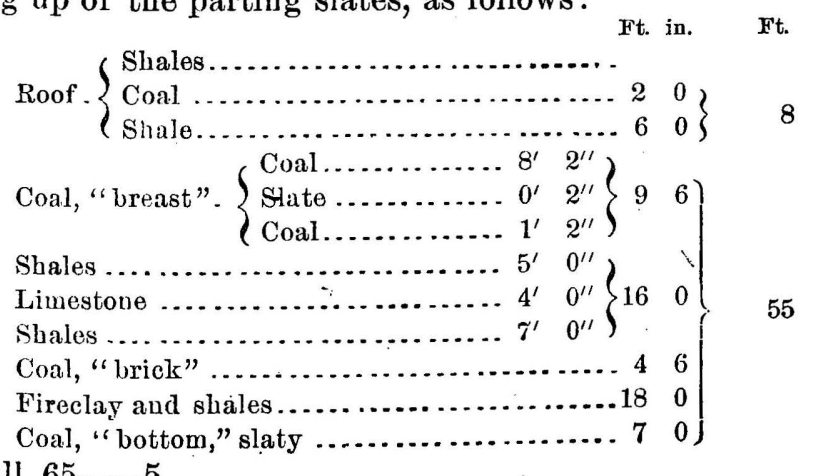

Bull. $65-5$ 
As will be seen from the above, it would appear that the three main divisions of the Pittsburgh bed, viz, " breast," "brick," and " bottom,". are here separated by shales, 16 and 18 feet thick respectively, instead of mere partings of a fraction of an inch, as on the Monongahela and elsewhere, thus spreading the 21 feet of coal through an interval of 55 feet. It is also worthy of note that although the partings have here increased so wonderfully, yet the total thickness of coal remains the same as in the central part of the Georges Creek Basin.

In the vicinity of Glenville, on the Little Kanawha River, this coal is $4 \frac{1}{2}$ to 5 feet thick, with a bony streak 16 inches below the top of the bed.

The structure on the Big Kanawha is given in Section 31.

Section at Huntington, Cabell County, West Virginia.--In the summits' of the hills sonth of Huntington, Cabell County, West Virginia, this coal displays the following structure:

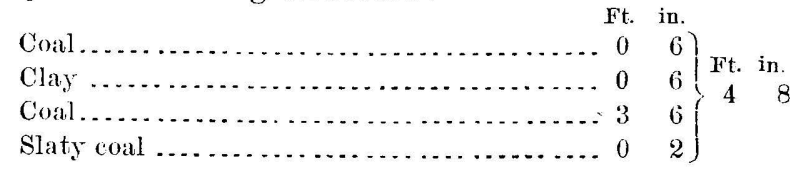

The farthest point to the sonthwest that this bed has ever been seen is in the summit of a hill orerlooking the Big Sandy Rirer, 10 miles above its month, where a small patch is caught in the center of the Appalachian trough, which, rising to the southwest, carries the coal above the highest hills on the Kentucky side of the Big Sandy. The coal is here 3 feet 2 inches thick and single bedded, or with only faint partings.

Section at Pomeroy, Meigs County, Ohio.-At Pomeroy, Ohio, the Pittsburgh coal shows thus, according to Prof. E. Lovejoy, Ohio Geological Survey, Vol. VI, page 636:

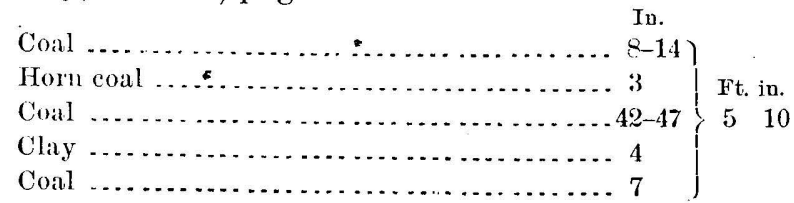

Section on Shade Creek, Ohio.-.-In the Shade Creek coal field of Meigs and Athens Counties, Ohio, Prof. Lovejoy finds a well developed rider coal 12 to 20 feet above the main bed, and often mined separately from it. The two have the following structure:

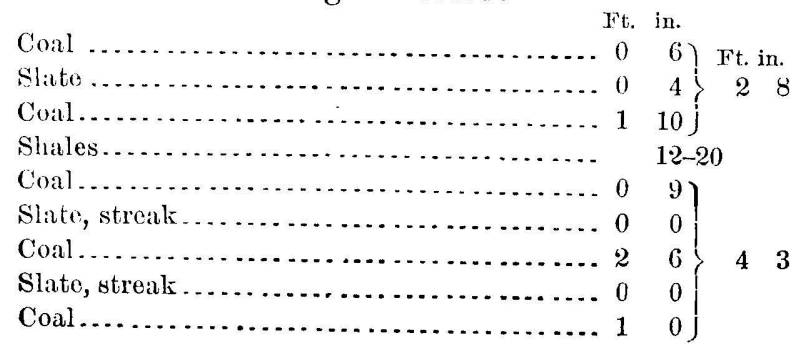


Section on Federal Creek, Ohio.-In the Federal Creek field of Athens and Morgan Counties, Ohio, the coal shows as follows (Lovejoy), op. cit., p. 648, Heyburn Brothers \& Co.'s mine, Berne Township, Athens County :

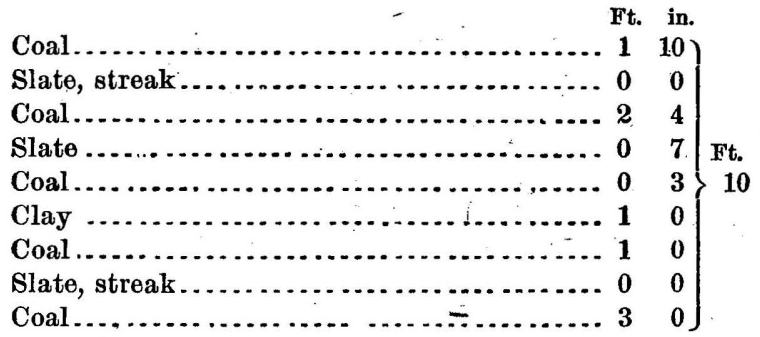

Section at Berry's mine, Ohio.-Berry's mine, in Homer Township, Morgan County (op. cit. page 650), gives the following:

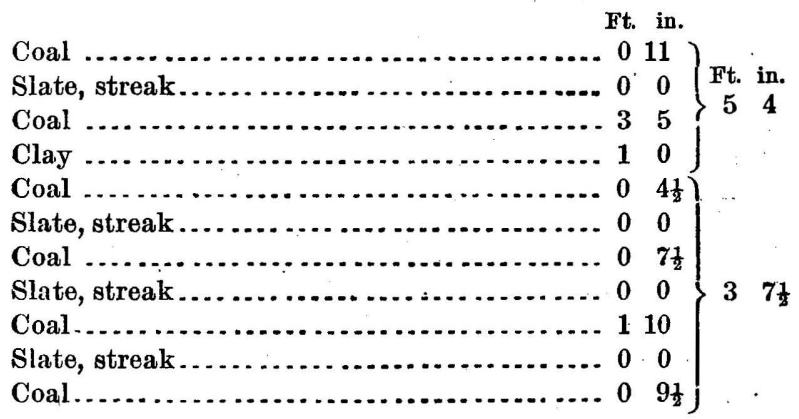

The clay stratum in these and other mines appears to correspond to the main clay parting which always separates the roof coals of the Pittsburgh bed from the main bench along the Monongahela, and the 12 to 20 feet of shales which separate the two coal beds in the Shade Creek field would appear to belong at the same horizon.

East from the barren area of the Pittsburgh coal of Morgan, Noble, and Washington Counties, Ohio, it comes in again with a fine develop. ment in Belmont, Harrison, and Jefferson.

Section in Belmont County, Ohio.-The following section from Ohio Geology, Vol. VI, page 621, exhibits the structure in the southern portion of Belmont County, Washington Township, as given by Prof. Brown:

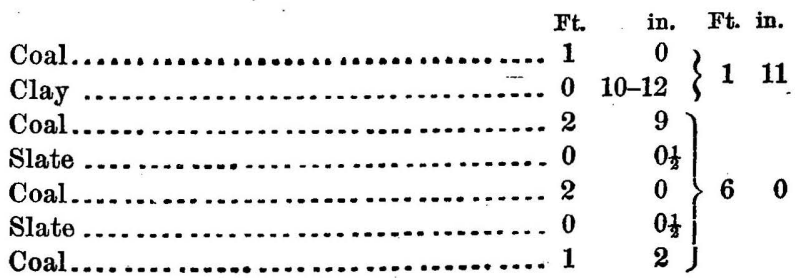


Section at Bellaire, Belmont County, Ohio.-In Bellaire the following is shown at Heatherington's mine:

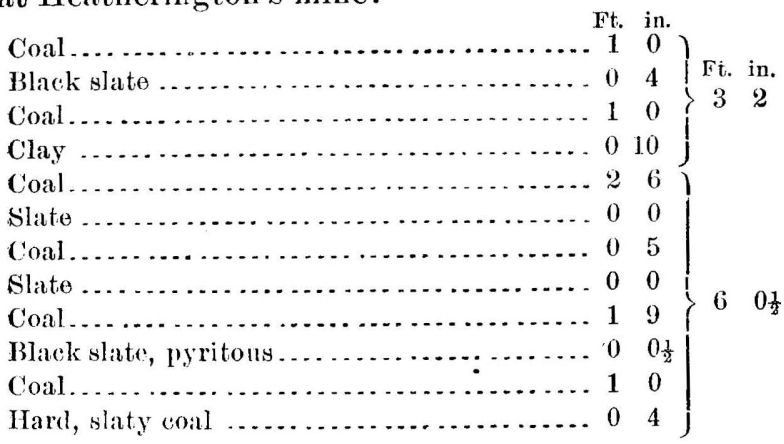

Section in Jefferson County, Ohio.-In Warren Township, Jefferson County, Ohio, this coal has the following structure (Brown, Ohio Geology, Vol. VI, page 603):

\begin{tabular}{|c|c|c|c|}
\hline Roof coal. & $\begin{array}{l}\text { Ft. } \\
2\end{array}$ & in. & Ft. in. \\
\hline 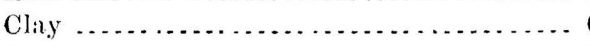 & 0 & 45 & \\
\hline 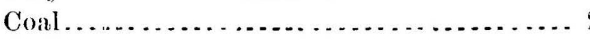 & 2 & 2 & \\
\hline 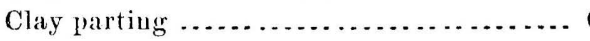 & 0 & 2 & \\
\hline 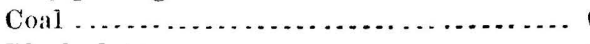 & 0 & 2 & \\
\hline 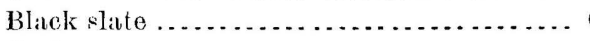 & 0 & $\frac{1}{3}$ & 411 \\
\hline Coal & 1 & 3 & \\
\hline 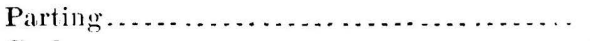 & & & \\
\hline Soal ............ & 1 & 2 & \\
\hline
\end{tabular}

Section in Hawison County, Ohio.-In German Township, Harrison County, Ohio, Stevenson reports the Pittsburgh coal as follows (Ohio Geological Survey, Vol. III, p. 212):

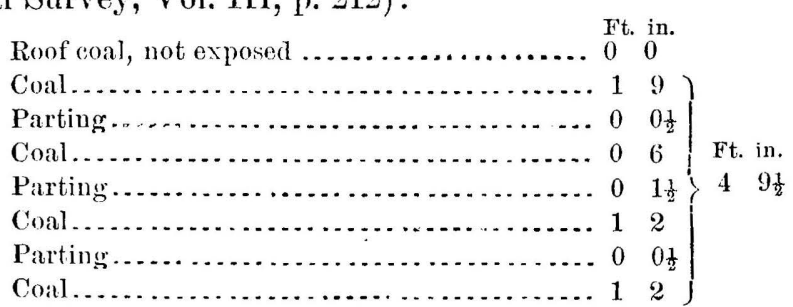

Section at Columbia mine, Westmoreland County, Pennsylvania.-As a typical section of this coal on the Monongahela River with reference to the structure of the main bench and roof, we may take that found at the Columbia miue, near Wẻbster and $36 \frac{1}{2}$ miles above Pittsburgh, as giren by Mr. J. Sutton Wall (K $\mathrm{K}^{4}$ Pennsylvania Geological Survey, p. 50):

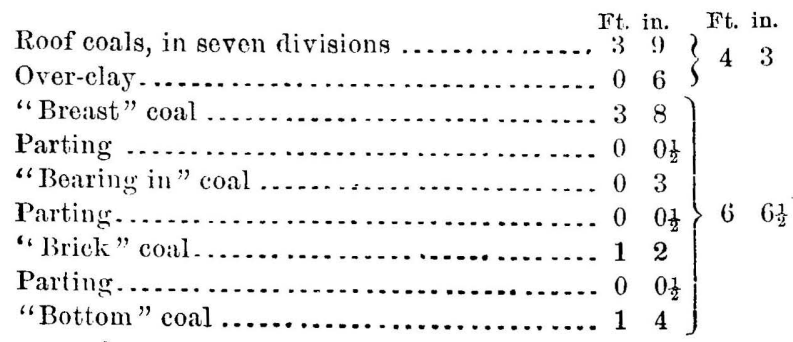


A careful comparison of the structure of this famous bed at a great many points very widely separated exhibits such a striking resemblance to that just given above that we can scarcely attribute it to chance, but wust find the explanation in the prevalence of nearly uniform conditions over the immense area covered by the Pittsburgh marsh.

The great excellence of this coal for steam and domestic purposes, and also for the manufacture of gas and coke, combine to render it the most valuable bed of coal in the entire Appalachian field.

Page plate 6 gives a view of this bed at Connellsville, the center of the coke-making industry, and in this the peculiar columnar structure of a typical coking coal is fairly shown.

lt was formerly believed that this bed would not make first-class coke over any large area outside of the Connellsville basin, but recent developments along the Monongahela River in Marion and Monongalia Counties, West.Virginia, have proved this belief erroneous, since it is there successfully coked on a large scale.

By crushing and washing, where there is too much sulphur present, there is no reason why this bed will not make coke equal to that of the Connellsville, throughout all of the region south and west from the latter.

The roof coals of this bed are never mined; not because they do not furnish good fuel, but because they are always interstratified with shale, which renders the mining difficult. These roof layers often amount to 3 or 4 feet of good coal, and thus this large quautity of fuel. is continually wasted, though the time will doubtless come in the distant future when the Pittsburgh bed will be mined over again for the coal now neglected in its roof and bottom.

FOSSILS OF THE UPPER COAL MEASURES.

The flora of the Pittsburgh roof shales as well as of the entire Upper Coal Measures is very meager, and only a few of the very common types, like Neuropteris hirsuta, $N$. flexuosa, and Pecopteris arborescens, are usually found, while the fauna of the whole group, so far as known at present, seems to be restricted to fresh water types. 
O H A P T E R I V.

THE BARREN MEASURES, OR ELK RIVER SERIES.

THICKNESS, CHARAC'TER, AND EXTENT.

Below the Pittsburgh bed we descend into a very natural group of rocks (No. XIV) which was long ago clearly recognized by the Rogers brothers in both Pennsylvania and Virginia. The group as defined by them extended from the base of the Pittsburgh coal down to the top of the Mahoning sandstone, and was called the Lower Barren Measures; but subsequent in restigation seems to render it more desirable to extend the group downward so as to include the Mahoning sandstone. This brings the group within the definite limits of two important and very persistent coal beds, the Pittsburgh above and the Upper Free. port below ; and hence, for purposes of comparison, study, and all the uses which classification subserves, is more desirable than the old system, since the top of the Mahoning sandstone is too variable a quantity for the limit of any group.

I have already indicated in a previous chapter that a larger view of the Carboniferous Measures, which overlooks details invaluable for classification to the working geologist, would run a line through the middle of the Barren Measures, and call ererything above it, to the top of the Dunkard Creek series, Upper Carboniferous; that below it, to the base of the Pottsville conglomerate, Middle Carboniferous, and the rest down to the Catskill, Lower Carboniferous. Such a classification of the Appalachian Carboniferous may be useful for comparison with the Carboniferous system in other regions and countries, but it is too general for the practical geologist, and can never supplant that which has stood the test of long and continuous use. Hence we deem it best to retain the limits of the Barren Measures intact, with the slight modification just suggested, and already long in use by the Second Geological Survey of Penusylvania.

I have adopted the name Elk River series as a geographical designation for these beds, since they are very finely exposed along that stream between its mouth at Charleston, West Virginia, and Braxton CourtHouse, or Sutton, nearly 100 miles above. 
This series, as thus limited above and below by important coal beds, consists of two very different members; an upper one composed largely of shales, therefore soft, easily eroded, and always making rounded hills and rolling topography ; the other, or lower, composed largely of massive sandstones which resist erosion and thus form steep cliffs, deep gorges, rugged topography, and wild scenery generally.

These sand rocks form a coping to the Lower Coal Measure hills, and cap the summits long after the soft beds above have disappeared.

The soil formed by the soft member, while rather thin and not to be compared in fertility to that of the Upper Coal Measures, yet with care and a liberal use of lime yields excellent crops and always makes good grazing lands. But the lower portion, being almost destitute of lime, and containing so much sand, forms a very poor soil, on which only the scantiest crops can be grown.

The upper portion always contains a large percentage of red and marly shales, which make a broad band of red soil from Pennsylvania clear through central West Virginia, to and beyond the Kentucky line on the one hand, and thence circling around through easteru Kentucky and southern Ohio, back to Pennsylvania again on the other. These red clays are the fruitful source of landslides, bad roads, and many other troubles. They cave easily in drill holes, and thus give endless annoyance and expense to oil and gas drillers. Their tendency to slide causes much expense in eleaning out railroad cuttings, so that a proper knowledge of their character by engineers would lead to economy of money in building and maintaining both railroads and wagon roads.

The coal beds of this series are, with one or two exceptions, noted for their variableness and uncertainty. They may be in fair development on one farm, and absent entirely on the adjoining one. They are also usually rich in ash and poor in carbon, and although they are patchy in their distribution, yet the main bedis appear to maintain the same horizons in the stratigraphy, and can thus be identified with reasonable certainty over wide areas. The sandstones found-within the limits of this group are of more economic importance than the coal beds, since the former nearly always furnish most excellent building stone, while the latter are commercially valuable only over limited areas. Iron ore in valuable quantity exists locally at several horizons in the Barrens, and these will be referred to hereafter in detail.

The limestones of this series, like the coals, are generally thin and impure, so that they are of more importance in determining'the stratigraphy than for economic purposes.

The entire thickness of the group varies much in different portions of the Appalachian field, reaching a maximum of 800 feet in the vicinity of Charleston, West Virginia, while along the northwestern outcrop of the beds in Ohio the minimum is not much above 300 feet.

In Pennsylvania and northern West Virginia the average is about 600 feet, but it sometimes runs up to 650 and down to 550 . 
The following sections, taken in the several portions of the Appalachian field, will serve to illustrate both the changing thickness of the series and the variable nature of the individual beds.

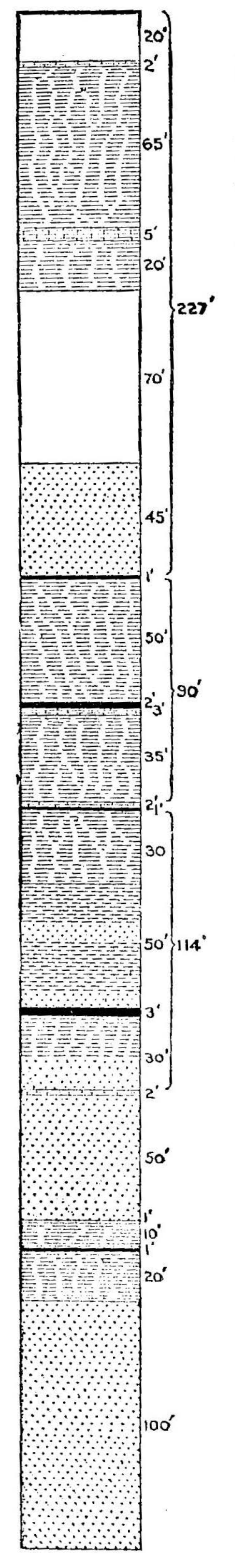

Section in the Pittsburgh region.-We shall begin the list at Pittsburgh, where the upper half of the Barrens is finely exposed, and the numerous carefully kept records of drill boles have revealed the constitution of the lower half, so that by uniting the two we get the following (Fig. 33):

\section{In Pittsburgh region.}

[See ruap, I m.]

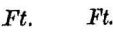

1. I'ittslurmin coal

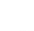

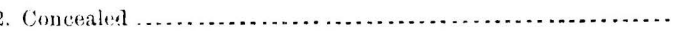

3. Limestone............................................

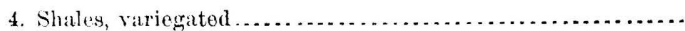

5. Limestone ...............................................

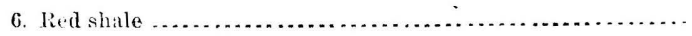

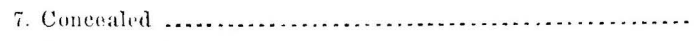

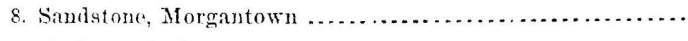

9. Coal, Elk Lick

20)

10. Shales, variegated

11. Coal

12. Limestone

13. Shales, viriegated....................................

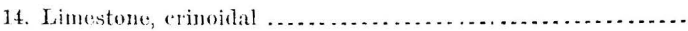

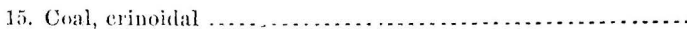

16. Sed and variegrated shale.

17. Simdly shiles and shidly sandstone ........................

18. Coal, Bakristown ....................................

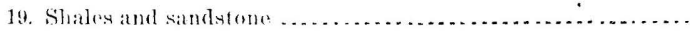

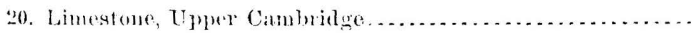

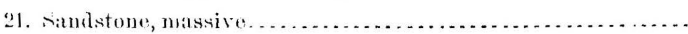

$4 ;$

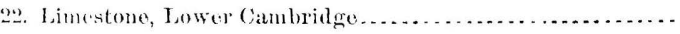

23. sinales.

24. (oal, Masontown ..................................

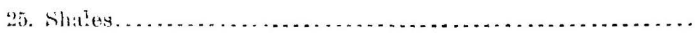

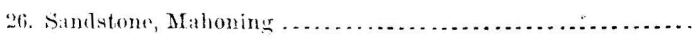

27. Upper Freeport coal. 
- Section at Sewickley, Pennsylvania.-At Sewickley, Pennsylvania, a diamond-drill hole was put down by Mr. Cochran Fleming as a test for coal. The cores were carefully preserved, and

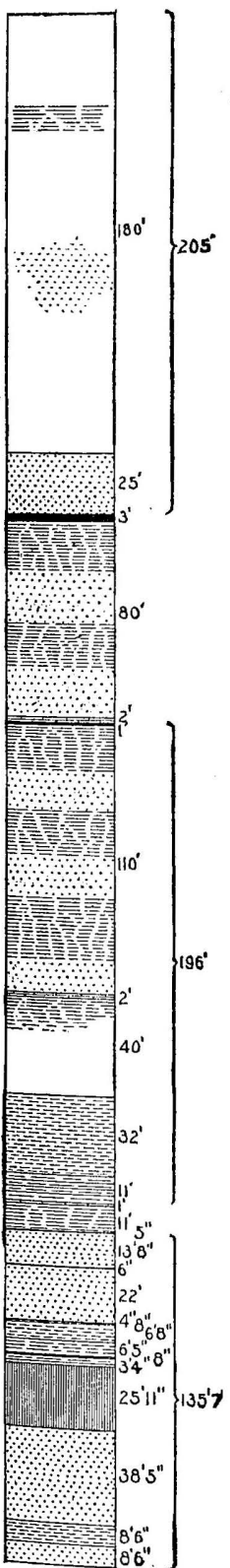

Frg. 34.-Section at from them I obtained a very accurate section of the lower portion of the Barrens, which, combined with the good surface exposures around Sewickley, gives the following structure (Fig. 34) for this series in that region :

Sewickley, Alleghany County, Pennsylvania.

[See map, H 1 .]

1. Pittsburgh coal

Ft. in. Ft. in.

2. Shales, sandstones, and concealed .

3. Sandstone, Morgantown, massive 180

4. Coal, Elik Lick

5. Shales and sandstone.

6. Limestone, crinoidal

7. Coal, crinoidal.

8. Red sbales and sandy beds.

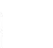

9. Limestone, gray, Upper Cambriàge ........... 2

10. Shales and concealed ....................... 40

11. Sandy shale ................................ 32 12. Dark slate ................................... 11

13. Limestone, dark, Lower Cambridge

14. Dark shales

15. Coal, Masontown

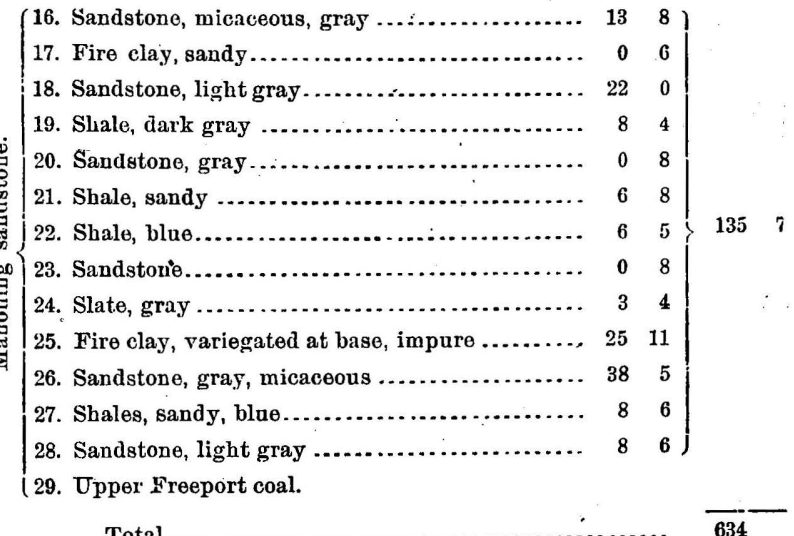

The interval No. 2 in this section was estimated, since the Pittsburgh coal is not found in the immediate vicinity of Sewickley, the highest stratum remaining there being the Morgantown sandstone, No. 3. 
Section on Dunbar Creck, Pennsylvania.-Eastward from the Pittsburgh region, we have a line of measurements of the Barren series which ex.

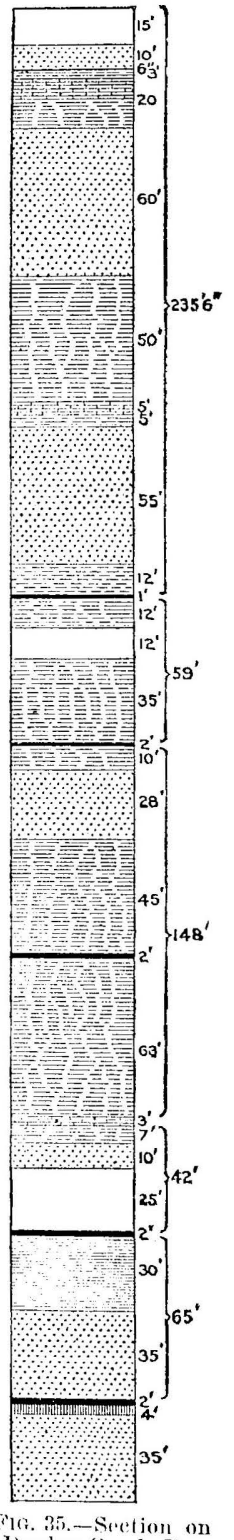

Fic. 35.- Sretion on
Dumbar Creck. Pat. tend across the Alleghanies. The first one is in the adjoining county of Fayette, at the foot of Chestnut Rirge, made by Prof. Stevenson and published in his Report KK, page 182. It is as follows (Fig. $35)$ :

Dunbar Creek, Fayette County, Pennsylvania. [See map, $\mathrm{K}$ n.]
1. Coal, Pittsburgh
Ft. in. Ft. in
2. Concealed . 15
3. Sandwtone .................................. 10
4. Coal, Littlo Pittsburgh ........................... 0
5. Clay ........................................ 3
f. Limestone and shale........................... 20
7. Sandstone, Comnellsville ........................ 60
8. Shilles ........................................ 50
9. Limestone.................................... 5

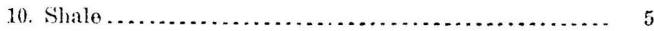
11. Sautstone, Morgantown ....................... 55

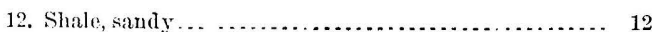

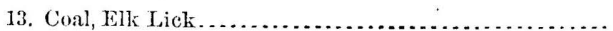

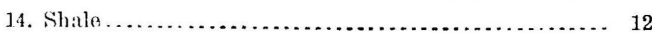
15. Concealed ..................................... 12
16. Shale, variegated ............................ 35
17. Coal, clay, crinoidal..............................
18. Shalles, brown ................................. 10
19. Sandstone ....................................... 28

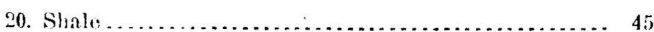
21. Coal, Bakerstown ............................... 2

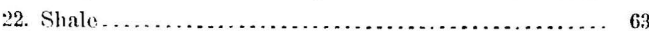
23. Limestone, Lower Cambridge....................

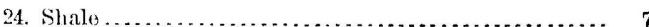
25. Suntsitone, argillaceous. ......................... 10

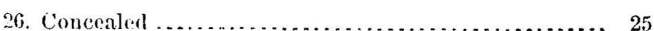

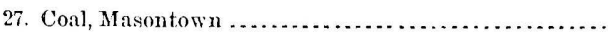

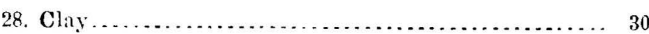
29. Samlstone, Upper Mahoning .................... 35

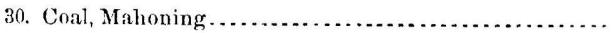
31. Fire clay
32. Samlstone, Lower Mahoning ...........
33. Coal, Upper Freeport.
Total.

The identification of the Lower Cambridge limestone in the above section is open to question, but the probabilities are in favor of the one given. 
Section at Ligonier, Pennsytrania.-Eastward from the last locality, and between Chestnut Kidge and Laurel Hill, the following section

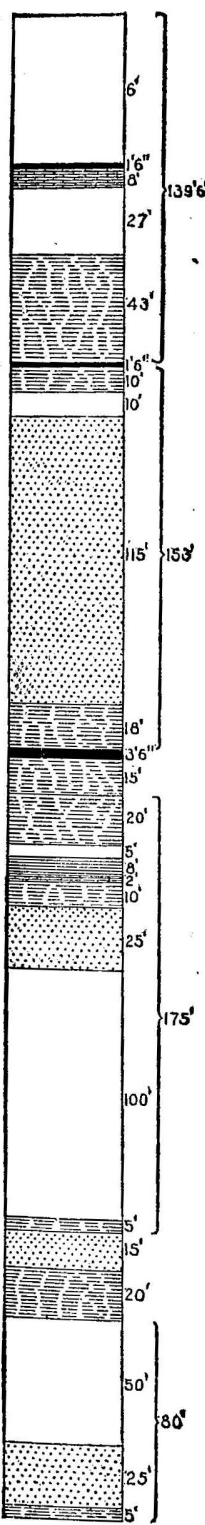

FIg. 36. - Section at Ligonier, Pa.

(Fig. 36) of these beds was measured at Ligonier, Westmoreland County, Pennsylvania, by Prof. Stevenson, as given in Report KKK, page 129:

\section{Ligonier, Westmoreland County, Pennsylvania.}

[See map, J p.]

Ft, in. Ft. in.

1. Pittsburgh coal

60

2. Concealed

3. Coal, Little Pittsburgh

4. Limestone

6. Shale, variegated

7. Coal, Little Clarksburg 43

8. Shale 10

9. Concealed 10 .

11. Shale, olive

12. Coal, Elk Lick

14. Limestone, green, fossiliferous 15. Shalo. 20

16. Sandstone

17. Clay

18. Limestone, ferruginous

19. Shale

20. Sandstone

21. Concealed

22. Shale

23. Sandstone, Upper Mahoning.

24. Shale

25. Coal, blossom, Mahoning

26. Concealed

27. Sandstone, Lower Mahoning

28. Shale

29. Coal, Upper Freeport.

Total. rapid rariation in the individual elements-of the Barrens, while the total thickness remains almost exactly the same. 
Section near Berlin, Pennsylvania._Still farther east, in the Berlin basin of Somerset County, Pennsylvania, and on the very summit of the Alleghany Mountains, we find this series with the following struc. ture (Fig. 37) as determined by Messrs. Platt, with some additions and modifications by the writer:

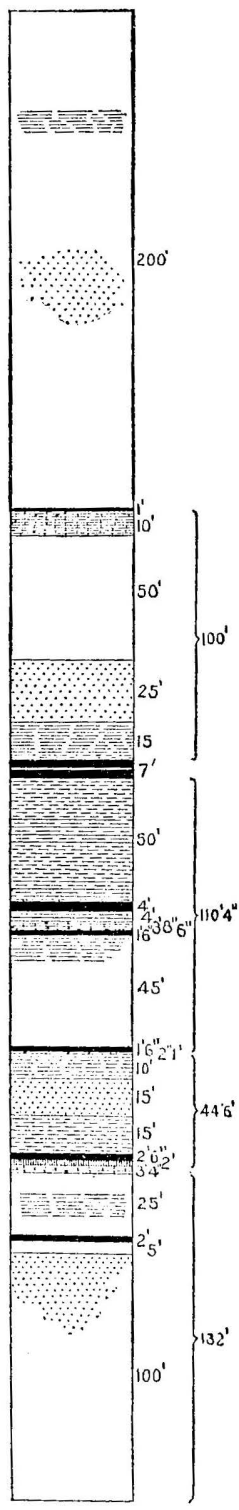

FIg. 37. Section near Berlin, $P_{i a}$.
Vieinity of Berlin, Somerset County, Pennsylvania.

\section{[See map, K p.]}

1. Pittsburgh con

Ft. in. Ft. in

9. Interval shates, santstch

3. Coal.

200

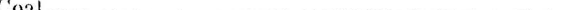

4. Limestone, gray and buff...................... 10

5. Concealed ........................................ 50

6. Sanilstono, massive ............................ 25

7. Shales, dark .................................. 15

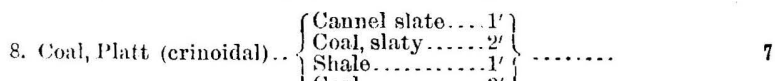

9. Sindy shales and black slates .................... 50

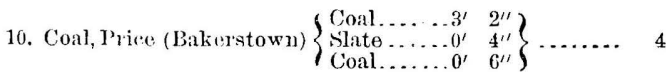

11. Slates, dark.

4

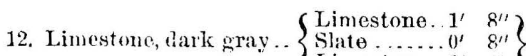
$\left\{\begin{array}{cc}\text { Slate } \ldots . . . .1)^{\prime} & 8^{\prime \prime} \\ \text { Limestone...1 } & 4^{\prime \prime}\end{array}\right\}$

13. Sbale

14. Coal .

15. Shales, and concenled

16. Coal, Coleman

17. Slate, dark

18. Limestone, Coleman (Jpper Cambrilge)

19. Shales ......................................... 10

20. Sundstone, and concealed ...................... I5

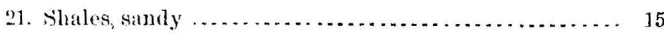

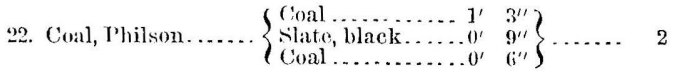

23. Fire clay

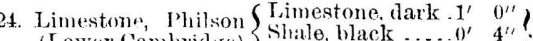

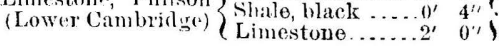

25. Coneraled, and shales

96. Coal, Masontown ..............

27. Concealed ...................

28. Sandstone, Mfahoning, aut concealed................ 100

29. Coal, Upper Freeport.

Total

Section at Broad Top, Pennsylvania-As showing the remarkable persistence of this series in its general thickness over the Penusylvania 
field, we give another measurement (Fig. 38) from far east of the

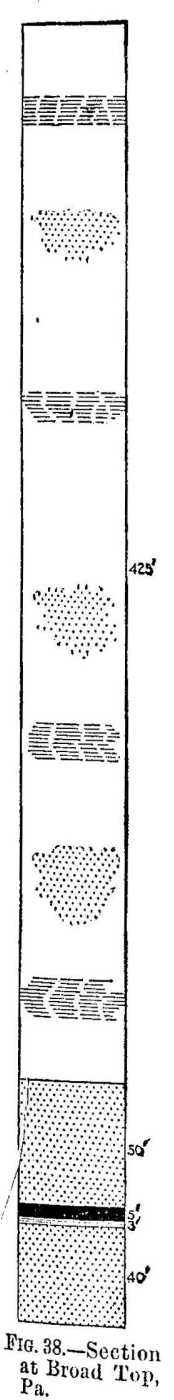
Alleghany Mountains, in the center of the Broad Top Basin, Bedford County, Report $\mathrm{T}^{2}$, Stevenson, page 60 :

Broad Top, Bedford County, Pennsylvania.

[See map, J t.]

Ft.

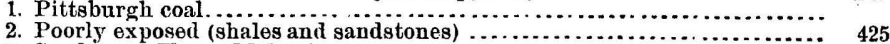

3.. Sandstone, Upper Mahoning .............................................

4. Coal, Mahoning.

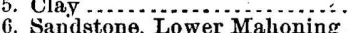

7. Coal, Upper Freeport.

Total.

523

Section opposite Steubenville, Ohio.-The next line of sections in this series across the Appalachian field will begin at Steubenville, on the Ohio River, and keeping south of the former line, end at Davis, Tucker County, West Virginia. The following succession (Fig. 39) was obtained opposite Steubenville by combining the surface observations with the records of drill holes and shafts :

Opposite Steubenville, Ohio.

$$
\text { [See map, Ij.]. }
$$

1. Pittsburgh coal

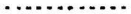

3. Shales, sandstone, and concealed ........

4. Sandstone, massive, Morgantown ......

5. Limestone, fossiliferous, crinoidal ......

6. Red shales

7. Concealed, with shales and flaggy sand Concealed, with shales and flaggy sand-

Coal

9. Shale

Limestone, fossiliferous, Lower Cam. bridge

11. Shales, drab

12. Shales, with cool Ma......

13. Shales, gray ........................

14. Sandstone, Mahoning, and concealed undere, Mahoning, and concealed 15. Coal, Upper Freeport.

Total

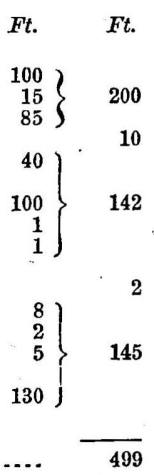

This shows a westward thinning of about 100 feet for the series between Pittsburgh and Steubenville.

Section under Washington, Pennsylvania.-Near Washington, Pennsylvania, many wells drilled for gas and oil have revealed the structure of the Barren Measures, although they lie many hundred feet below the surface.

One of these borings was supervised by Prof. Linton, of Washington and Jefferson College, and from the record thus obtained of the Thayer oil well, as

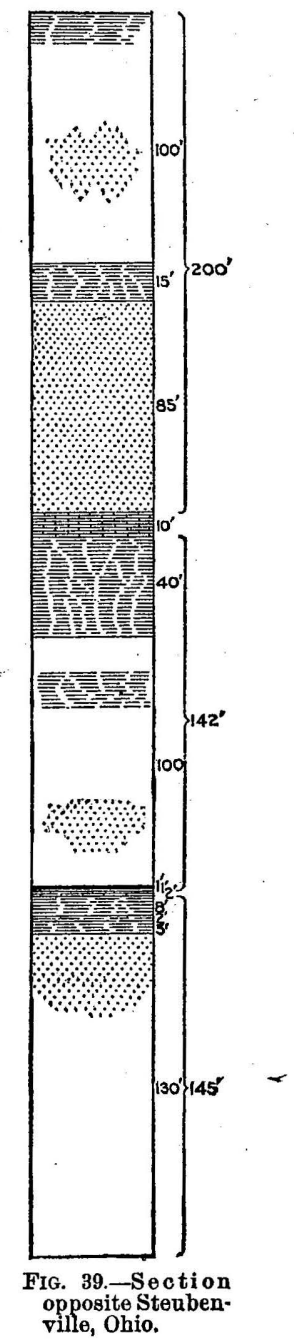


published in Pennsylvania Geological Report, 1886, page 764, we get the following for the Barrens there (Fig. 40):

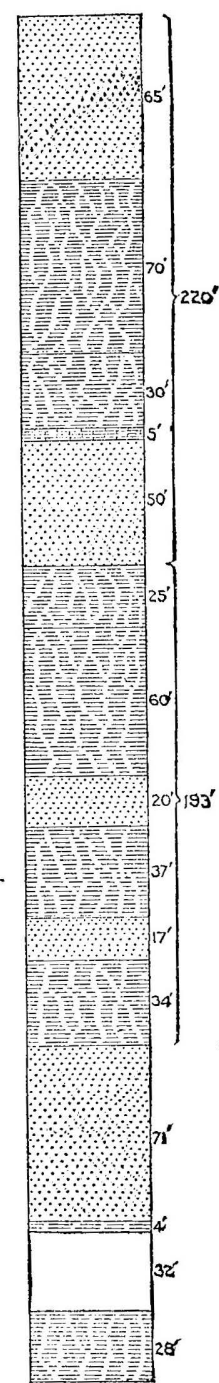

Fif: 40.-Section at
Washington, Pennsylvania.

[See map, J k.]

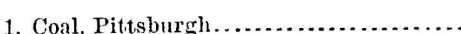

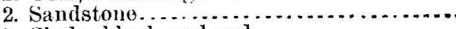

3. Shale, black and red..................

4. Shale, red.

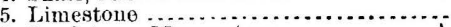

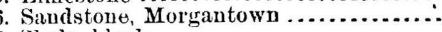

7. Shale, black

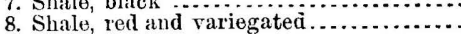

9. Savdstone, hard

10. Shale, black

11. Sandstone

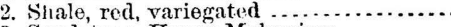

13. Sandstone, Upper Mahoning

14. Shale, olive green

15. Sandstone, Lower s cray, fineflaggy ...15' Mahoning.

16. Shale, dark, to place for Upper kreeport coal .................................

Total

Nos. 8 and 12 are the beds which "cave" and give the oil drillers so much trouble.

Section near Cannonsburg, Pennsylva. nia.-In the vicinity of Cannonsburg, a few miles northeast from Washington, the record of a well drilled for gas on the Boyce farm, furnished me by Mr. Wm. S. Stevenson, assistant superintendent of the Philadelphia Natural Gas Company, gives the following (Fig. 41) as the structure of the Barrens there:

Near Cannonsburg, Washington County, Pennsylvania.

[See map, J 1.]

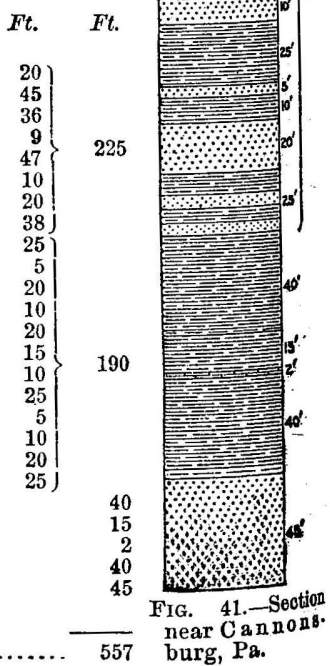

1. Coal, Pittsburgh....................

2. Timestone, blue, hard .................

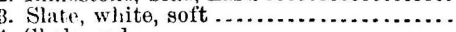

4. Shale, red.

5. Slate, black

(n)

7. Saudstone, gray, hard

8 Slite llack

9. Sundrtoure rmay hard Morgantown -...

10. Shale red se

10. Shale, red....

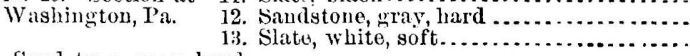

14. Sandistoue, gray, hard

15. Slate, black.

16. Samdstone, gray, hard.

17. Slate black.

18. Sandstone, gray, hard

19. Slat $\theta$, black

20. Samelstone, gray, hard

22. Slate, black, soft

23. Slate, with coal,

24. Shells, yray, hard
25. Slate, black, soft

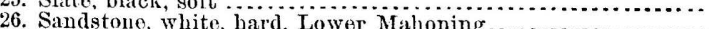

27. Coal, Upper Freeport.

Total 
Section at Morgantown, West Virginia.-From Washington across to Morgantown, West Virginia, the Barren Measures, as revealed by bor-

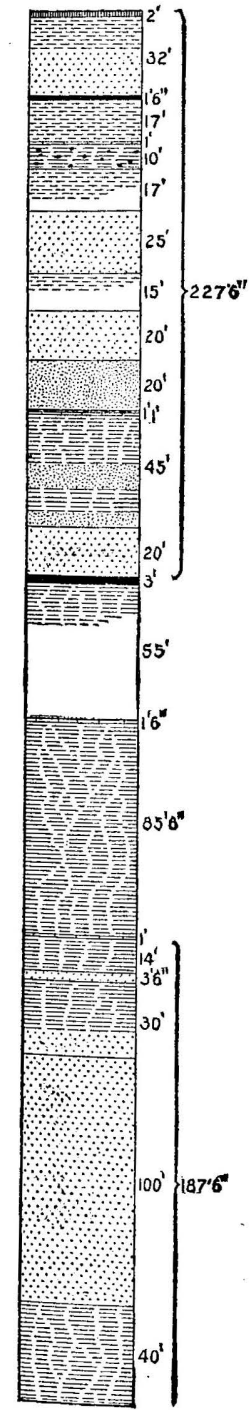

FIG. 42.-Section at Mo gantown, W. Va. ings, hold about the same thickness as in Washington County. In the vicinity of Morgantown the entire column of the Barrens is exposed, and there the following structure is exhibited (Fig. 42):

Morgantown, Monongalia County, West Virginia.

\section{[See map, M m.]}

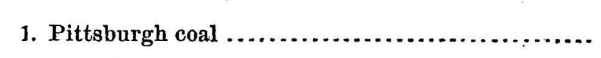

2. Fire clay .................................. 2

3. Sandy shales and sandstone.................... 32

4. Coal, Little Pittsburgh ......................... 16

5. Sandy shales .............................. 17

6. Limestone..................................... 1

7. Yellowish shales with iron ore................ 10

8. Sandy shales, and concealed .................... 17

9. Sandstone, rather massire ...................... 25

10. Sandy shales, and concealed................... 15

11. Massive sandstone ............................. 20

12. Bluish green sandy beds ...................... 20

13. Black slate, fossiliferous...................... 1

14. Limestone, Clarksburg ........................ 1

15. Sbales and sandy beds........................ 45

16. Sandstone, Morgantown ....................... 20

17. Elk Lick coal..................................

18. Shales, and concealed .........................

19. Limestoñe, crinoidal.......................... I 6

20. Variegated shales ............................ $\quad 85 \quad 6$

21. Limestone, Upper Cambridge.................... 1

22. Shales ...................................... 14

23. Sandstone, Upper Mahoning...................... 3

24. Shales and shaly sandstone.................... 30

25. Massive sandstone, Lower Mahoning.............. 100

26. Shales ........................................ 40

27. Coal, Upper Freeport.

Total.

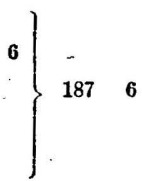

561

The black fossiliferous slate, No. 13, represents the horizon of the Little Clarksburg coal, and is here filled with fish teeth and scales. The Upper Freeport coal is about 100 feet under the river at the Morgantown wharf, but south ward it rises very rapidly and comes up to the bed of the river at the mouth of Coburn's Creek, 2 miles above. It is there about 4 feet thick and very pure. 
Section near Little Falls, West Virginia.-In the vicinity of Little Falls, Monongalia County, 9 miles above Morgantown, the basal mem.

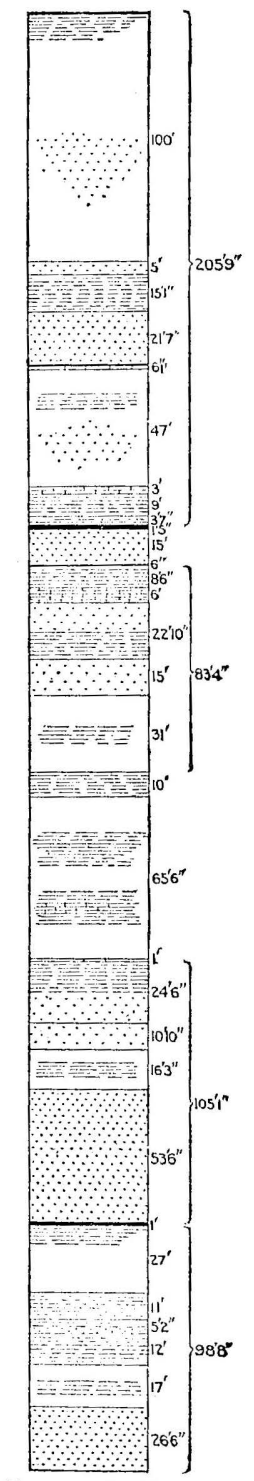

Fif. 43.-_Rection at Lit tle Falls, W. Va.

bers of the Barrens can be obtained more in detail than in the Morgantown section, and the following (Fig. 43) shows the structure there:

\section{Little Falls, Monongalia County, West Virginia.}

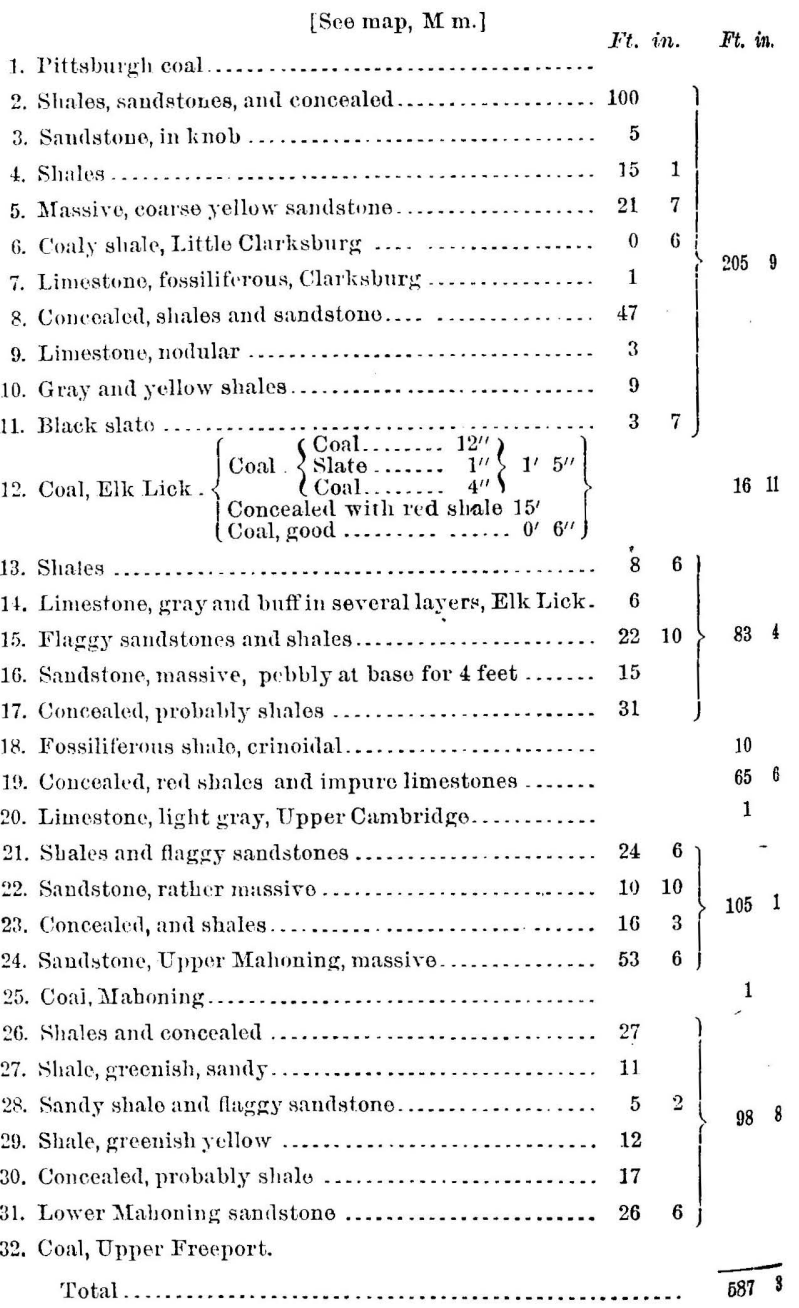

This section illustrates well the variability of the Barren Measures, when compared with the previous one, taken only a few miles distant. 
Section at Newburg, West Virginia.-The syncline between the Ohestsut Ridge and Laurel Hill anticlines crosses the Baltimore and Ohio Railroad at Newburg, Preston County, West Virginia,
about 15 miles east from Little Falls, and there the
Barren Measures admit of vertical measurement by
combining surface exposures with the record of the
Orrel Coal Company's shaft. The result is as follows
(Fig. 44):

Newburg, Preston County, West Virginia.

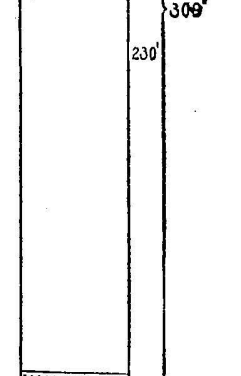

\begin{tabular}{|c|}
\hline [See map, N m.] \\
\hline 1. Pittsburglı coal ............... \\
\hline 2. Firo clay ...................... \\
\hline 3. Concealed.......... \\
\hline 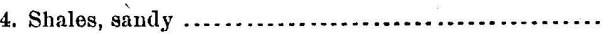 \\
\hline 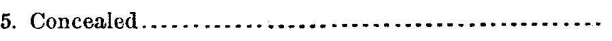 \\
\hline 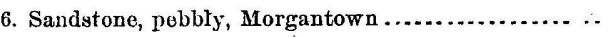 \\
\hline 7. Concealed ........ \\
\hline 8. Sandstone, flaggy .. \\
\hline 9. Shales, sandy .... \\
\hline
\end{tabular}

Ft. Ft.

10. Shales, dark, fossiliferous (crinoidal)
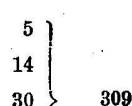

230

$30 \mathrm{~J}$

$\left.\begin{array}{l}15 \\ 18\end{array}\right\} \quad 35$

10 )

15

11. Concealed.

20

12. Red, marly shalo

14. Sandstone, yellow

15. Concealed

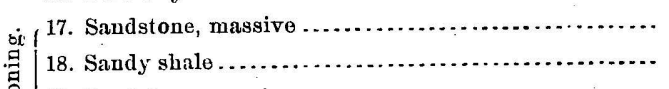

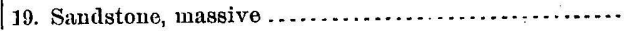

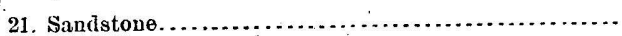

12

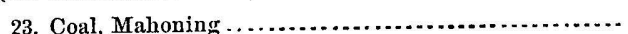

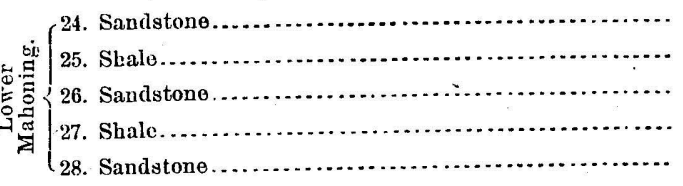

29. Coal, Upper Freeport.

Total.

This is in the same geological trough as the section, - 3 at Ligonier (Fig. 36), and, as will be observed, agrees:

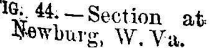
with it in having an unusually large interval between the Pittsburgh coal and the base of the Morgantown sandstone. It is possible that the Upper Mahoning sandstone should not include Nos. 17-20 at this locality.

Bull, 65-6 
Section near Fairfax Knob, West Virginia.-About 50 miles east from Newburg we come to the North Potomac Coal Basin, the south.

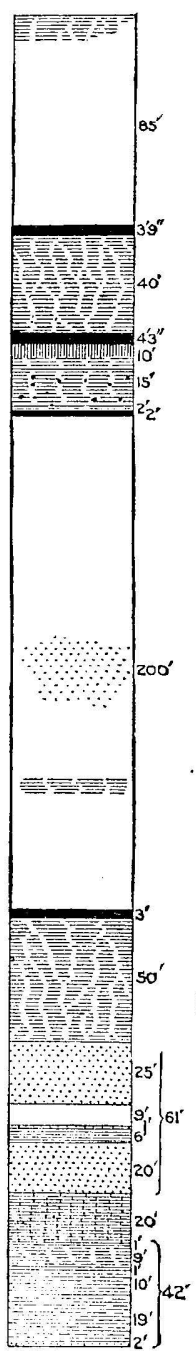

Fu. 45.-. Section iat Fairtax linob, W ward extension of the Cumberland or Georges Creek field of Maryland, and there, in the vicinity of Fairfax Knob, Tucker County, West Virginia, the Barrens exhibit the following structure (Fig. 45):

Fairfax Knob, Tucker County, West Dirginia.

[See ruap, O o.]

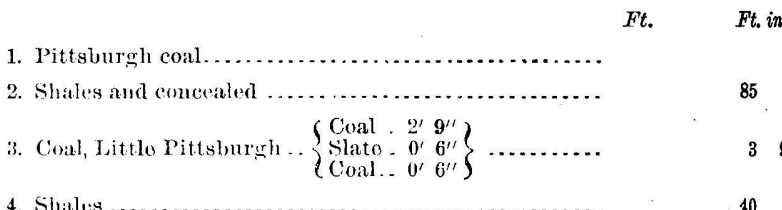

10

Coal.... $1^{\prime}, 5^{\prime \prime}$

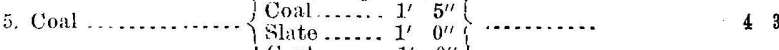

6. Fire rlay and shales .......................... 10

7. Bho shales with iron ore ..................... 15

8. Black slate ................................

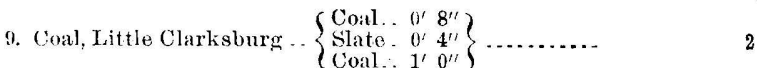

10. Concealed, with sandstones and shales ........... 200

11. Coal, and black slate, Masontown............... 3

12. Shales .................................. 50

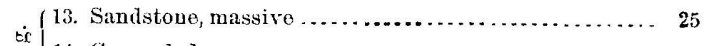

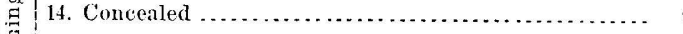

$\{15$. Saulstone, soft.............................. 1$\}$

16. Clay, yellow ............................... 6

17. Sandistone ................................ 20

18. Iinestone, Mahoning......................... 20

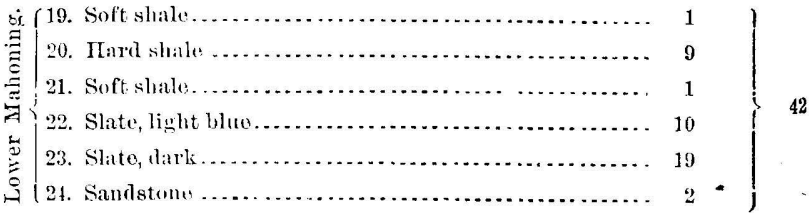

25. Coal, Uppor Frenport.

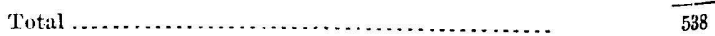

The last 100 feet of the section was obtained from the record of a diamond drill hole put down by the West Virginia Central Railroad to test the character of the Upper Freeport coal. The writer saw sam. ples of the Mahoning limestone, taken from the drill hole, and it was a dark gray, rather pure limestone.

No. 5 is a second Little Pittsburgh coal which is occasionally present in the l'otomac basin and elsewhere. 
Section in Guernsey County, Ohio.-Toward the northwestern side of the Appalachian basin, in Ohio, the Barrens are thinner than elsewhere,

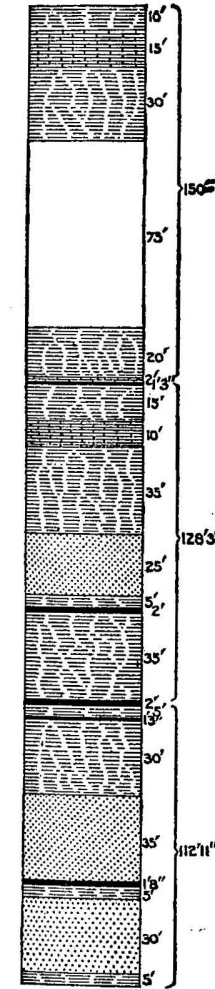

FIg. 46.-Section in Guernsey County,

Section at Burning Springs, West Virginia.--At Burning Springs, Wirt County, West Virginia, the Barren Measures have the following structure (Fig. 47), according to Mr. Minslaall:

Burning Springs, Wirt County, West Virginia.

$$
\text { [See map, P g.] }
$$

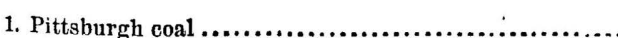

2. Shales ....

3. Limestone

Ft. in. Ft. in.

4. Concealed

5. Limestone, crinoidal.

6. Coal, crinoidal

7. Shales

8. Limestone...................................... 3

9. Concealed ................................... 200

10. Sandstone..................................... 40

11. Shales.

12. Coal, Uppor Freeport.

Total. Ohio.

Ft. in. Ft. in.

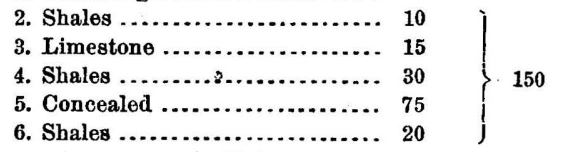

7. Limestone, crinoidal..........

8. Coal, crinoidal...............

1

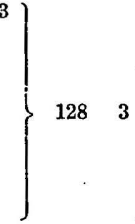

. 1

3

8

11211

$395 \quad 2$ as may be seen from the following section (Fig. 46), made by Mr. F. W. Minshall, in Guernsey County,
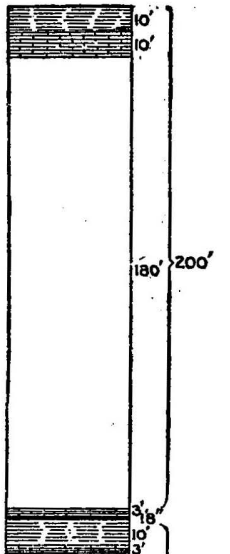

高:

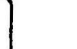

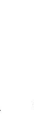


Section near Huntington, West Virginia.-Near the southwestern limit of the district, in the vicinity of Huntington, West Virginia, the

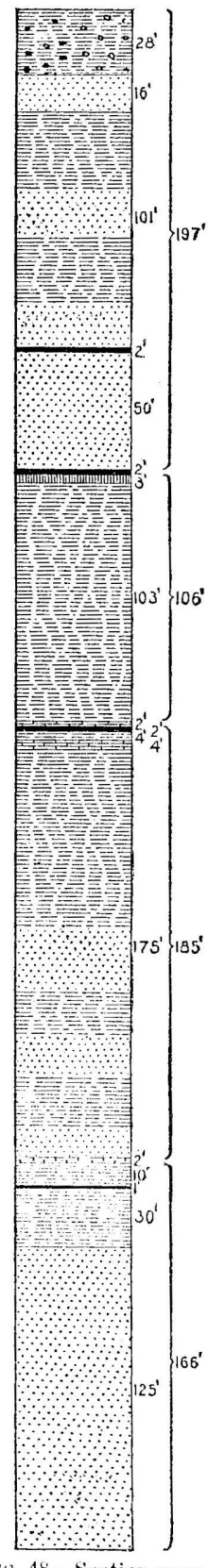

Fin. 48 - Section near Huntiugton, W.Va.
Hun
Barren Measures have the following structure (Fig. 48) according to the determinations of Mr. A. G. Selby, who made careful ineasurements of the rocks exposed there, and combined them with the record of a boring for gas :

Ticinity of Huntington, West Firginia, along Ohio River.

[Seo mal, S b.]

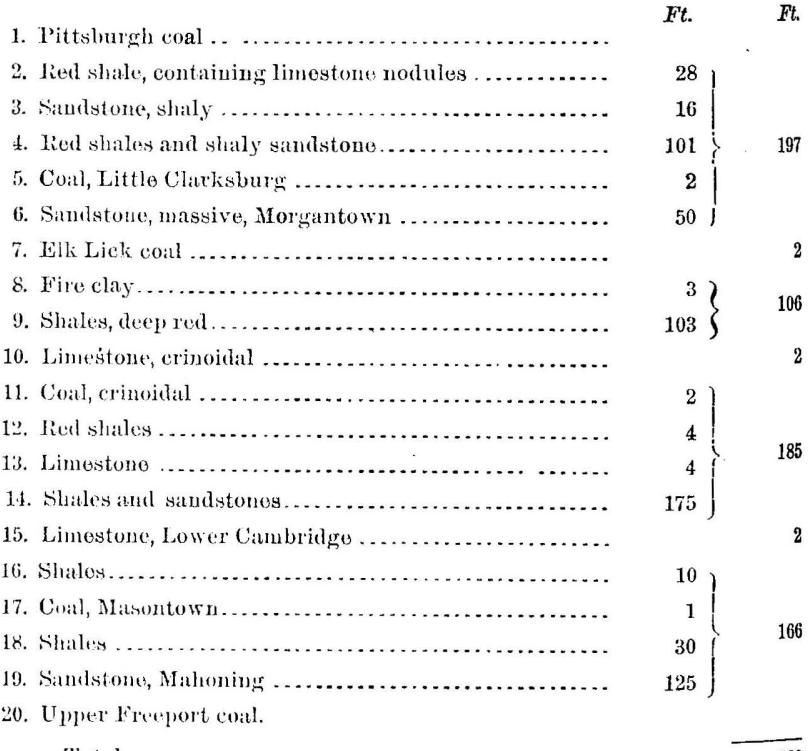

T'otal .........................................

This is nearly twice the thickness that the Ohio geologists report for the Barrens along the nortlwestern margin of their outcrop, but all of the meas. ures thicken very rapidly toward the southeast from this portion of Ohio. It is possible, however, that Mr. Selby may have gotten some of the elements of the section too thick, since there is no single point between Huntington and the Big Sandy where a rertical measurement of all the members can be made. The true thickness can not be much under 600 feet at least. 
Section near Charleston, West Virginia.-In the vicinity of Charleston, West Virginia, and just north from it, the Barren Measures attain a

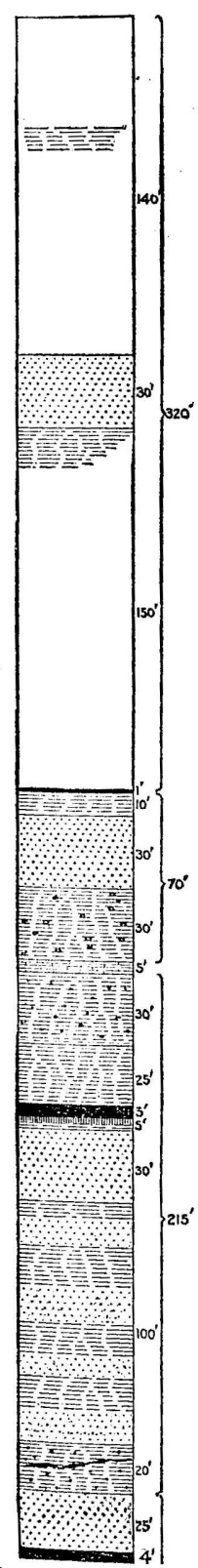
greater thickness than anywhere else in the Appalachian Basin, so far as known. The following structure (Fig. 49) may be observed along the Great Kanawha River there, and its tributary, Two-mile Creek :

Near Charleston, West Virginia.

[See map, $\mathbf{S}$ f.]

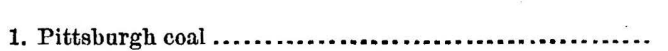

2. Concealed red shales and sandstone..................

3. Sandstone, massive ......... $\begin{array}{r}140 \\ 30\end{array}$

4. Red shales, sandstone and concealed ................. 150

5. Coal, Elk Lick .....................................

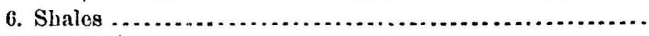

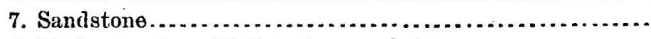

8. Shales, marly, with limestone nodules..................

9. Limestone, impure (crinoidal horizon)

10. Dark red shales with iron nodules ...................

11. Shalos

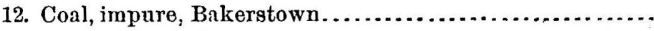

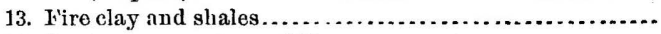

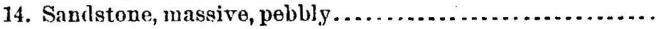

15. Shales and sandstono

Ft. $\quad$ Ft.

16. Shales, with streaks of conl, Masontown ................

17. Sandstone, very hard . . . . . . . . . . . . . . . . . . . .

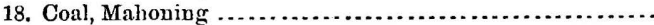

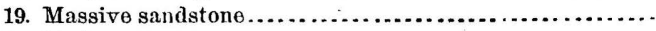

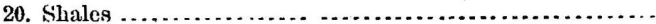

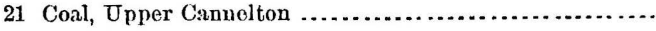

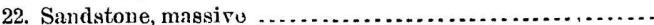

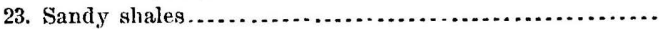

24. Coal, Middle Cannelton

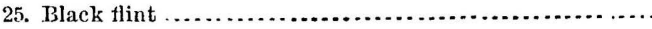

26. Shales

27. Coal, Upper Freeport.

Total

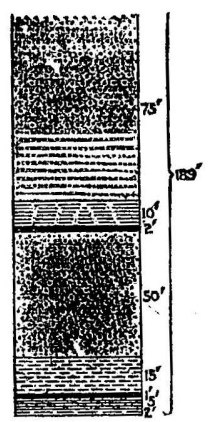

FIG, 49.-Section near Charleston, W. Va.

As may be seen from these sections just given, many of the beds which have received distinct names are not persistent. They occur at some localities but are wanting in others, and hence are so variable that they are never all found in one section.

We shall now take up the more important members of the series and describe them in more detail as exhibited at their type localities and elsewhere. 


\section{CHARACTERISTIC HORIZONS.}

TIIE PITTSBURGII COAI ORES.

In Fayette County, Pennsylvania, a group of iron ores come immediately below the Pittsburgh coal, and have been mined for the manufacture of iron for nearly 75 years. They have been very carefully studied by Stevenson, who describes them in his report (KK) of the Pennsylvania Geological Survey. He gives the following as the general section of the ores:

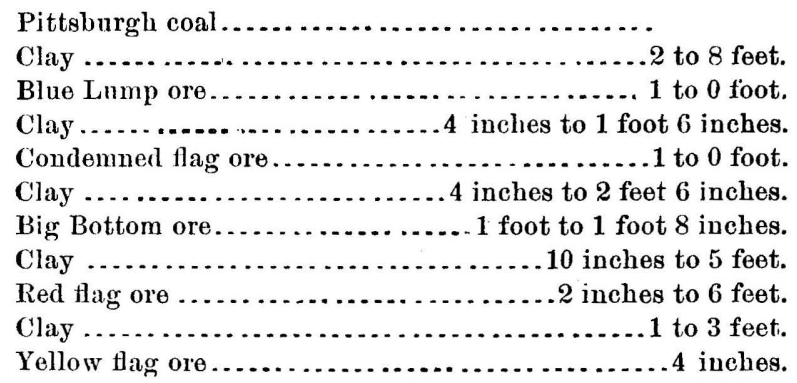

This suecession does not, of course, represent the structure of the ore layers at all localities, as the thickness and quality are constantly vary. ing.

The "Blue Lump" and the "Big Bottom" beds are of the most im. portance, and it is from the former one especially that Mr. F. H. Oliphant manufactured iron so long and successfully at Fairchance. These ores are confined principally to the Blairsville basin, in Fayette. County, though they extend into the edge of Monongalia County to the south, and have been recognized on the edge of Greene County to the west.

When these ores are not present their places are often occupied by ferruginous limestones or shales, though occasionally a sandstone stratum comes in close under the coal and cuts out everything else. This interval, immediately below the Pittsburgh, for 30 to 40 feet is more variable than any other portion of the Barrens, and hence it is useless to attempt to classify its rocks.

THE LITTLE PITTSBURGII COAL.

At a varying interval of 25 to 60 feet from the top of the Barrens there often occurs a thin and usually impure coal bed, which has been termed the Little Pittsburgh coal, from the fact that it is so close to the great bed above. The thickness selcom exceeds two feet, and it is often only half that. The best development of this coal which the writer has ever seen occurs in Fairfax Knob, Tucker County, West Virginia, at the locality of Section 45 , where the bed is neariy $\dot{4}$ feet thick and is locally known as the "coking vein," from the fact that it has the typical structure of a good coking coal. 
Occasionally there appear to be two of these beds, one at 20 to 30 feet below the Pittsburgh and the other at 50 to $\mathbf{7 5}$ feet below, but they may probably both be splits from the same bed.

The Little Pittsburgh coal is quite persistent at the northern end of the Appalachian coal basin, but it disappears southwestward across West Virginia and is seldom seen beyond Harrison County. It also fades away southward in Ohio, since it does not appear in any of the Ohio sections, unless it should be the "Jeffers" coal of Prof. Andrews, in Gallia County. That, however, may possibly represent the Pittsburgh bed. In the vicinity of Wellersburg, Somerset County, Pennsylvania, there appear to be two of these Little Pittsburgh beds, and the upper contains 3 to 4 feet of good coal, while the lower is only 18 inches thick.

THE PITTSBURGH LIMESTONES.

There are very frequently two limestones in the shale interval of 50 to 75 feet below the Pittsburgh coal, one of which comes above the Little Pittsburgh coal and the other a few feet below. They are both kuown under the general name of Pittsburgh limestone; but it would be better to call the first one Upper Pittsburgh and the other one Lower Pittsburgh. The first is seldom more than 3 to 5 feet thick, but the latter is occasionally much thicker, as it is the more persistent of the two, being purer and frequently quarried and burned into lime for agricultural and other purposes.

\section{THE CONNEILSVILLE SANDSTONK.}

At a short interval under the Lower Pittsburgh limestone there is often found a massive sandstone which is frequently conglomeritic. This rock rises from the bed of the Youghiogheny River at Connellsville, and was named from that locality by Dr. Stevenson. Being one of the cliff rocks in the Barren Measures, it has played an important part in shaping their topography. It is especially hard and massive in the Cumberland or Georges Creek basin, and the rounded hills which hold the "Big" (Pittsburgh) "vein" rest on a platform of this rock, which, owing to its erosion-resisting power, makes a bold terrace far up the mountain sides after all the soft beds above have disappeared. It is this great bed of pebbly sandstone that caps the summits in the center of the trough south from Elk Garden, after the Pittsburgh coal has disappeared, forming almost level plateaus over thousands of acres where the great Pittsburgh bed is missed by an interval of only 50 to 60 feet.

The same pebbly sandstone marks the summits of the hills at Belington, Barbour County, West Virginia, and forms huge cliffs at many points along the Monongahela River between Fairmont and Morgantown.

At Connellsville the top of this stratum lies about 60 feet under the Pittsburgh coal; but this interval is sometimes as small as 40 feet, and 
again increases to 80 or 90 . When not pebbly it frequently furnishes excellent building stone. The thickness varies from 25 to 50 feet, but it is often absent as a massive rock, and then its place is filled with sandy shales or flaggy sandstone.

THE LITTLE CLARKSBURG COAL.

By this name has been designated a bed of slaty coal which occasionally makes its appearance close under the Connellsville saudstone, and 100 to 125 feet below the Pittsburgh coal.

At Clarksburg, West Virginia, the coal in question crops out along the bed of Elk Creek for a considerable distance, and is $1 \frac{1}{2}$ to 2 feet thick, but poor and slaty. It is called Little Clarksburg to distinguish it from the Pittsburgh coal, which is extensively mined in the vicinity of that town, and is locally known as the Clarksburg bed.

Very frequently this coal is represented by a bed of black slate, which is filled with fish remains, teeth, scales, etc. The deposit in question is rarely more than $1 \frac{1}{2}$ to 2 feet thick, and is often absent altogether, so that it is of very little economic importance, though in the Wellersburg region of Somerset County, Pennsylvania, it attains a thickness of nearly 6 feet, and contains some good coal, being known as the " 6 -foot" bed.

TIIE CLARKSBURG LIMESTONE.

Directly under the last described coal there often occurs a limestone which is finely exposed in the vicinity of Clarksburg, along the bed of Elk and the West Fork River. The upper portion is there rather slaty, and filled with fossil ostracoids and fish remains. The next layers under this are very compact, and come out in peculiar rhomboidal blocks. This entire limestone series is 20 to 30 feet thick, and some of the layers are quite ferrnginous, so much so that they were mined for ore many years ago at an old charcoal furnace on Elk. Some iron ore was also obtained near Clarksburg from the roof shales just above the Little Clarksburg coal, and used in this furnace. The Clarksburg limestone is rather widely distributed in Pennsylvania and northern West Virginia, and is frequently mined, since many of its layers furnish good lime for fertilizing and building purposes.

THE MORGANTOWN SANDSTONE.

At 25 to 40 feet under the Clarksburg limestone, and separated from it by soft shales, we find one of the great sandstone horizons of the Barren Measures. This rock was named by Dr. Stevenson from its fine exposure at Morgantown, West Virginia, where it has been extensively quarried and used in building the State University and other structures. At this typical locality the top of the stratum lies about 200 feet below the Pittsburgh coal, and the thickness of the sandstone is 25 feet. It is of a yellowish gray cast, of medium grain and hard. ness, and splits readily into blocks of any desirable size. Scattered 
through the rock are stains of peroxide of iron and also a considerable quautity of feldepar grains, which are generally decomposed, thus giving the surface of the stone a mealy look. In some of the crevices and cavities of the sandstone pure kaolin has accumulated from this source. The base of the sandstone is often conglomeritic and sometimes brecciated.

This is a quarry sandstone nearly everywhere that its outcrop extends. All along the Monongahela River it has been quarried and nsed in building the locks of the Slack Water Company. The stone dam, No. 9, was built of rock from this stratum. It is one of the most persistent members of the Barren Measures, and often makes high cliffs. It caps the hills in the vicinity of Grafton, West Virginia, where it is also quarried, and it makes a line of conspicuous bluffs from there to beyond Newburg, along Three Fork, and far up into Barbour County along the Valley River. Along the North Potomac River, in Mineral, Grant, and Garrett Counties, the same rock is found, and on the Great Kanawha, Guyandotte, Big Sandy, Big and Little Muskingum, and other tributaries of the Ohio, this bed is generally conspicuous. At Huntington, West Virginia, on the banks of the Ohio, it is $\mathbf{5 0}$ to 60 feet thick, while on Crooked Run, Monongalia County, near the Peunsylvania line, the stratum is $\mathbf{1 0 0}$ feet thick. It is the first oil rock on Dunkard Creek, and some of the wells produced largely from it. In the deep borings of Washingion County, Pennsylvania, where it underlies the surface 500 to 1,000 feet, this stratum is 35 to 50 feet thick, and generally contains salt water.

THE ELK LICK COAL.

Immediately under the Morgantown sandstone, or separated from it by only a few feet of shale, there comes a coal of very wide distribution which occasionally attains workable dimensions.

This name was given the coal in question by the First Geological Survey of Pennsylvania, but the place of the bed in the series remained uncertain till Messrs. Platt, of the Second Survey, recently determined the matter finally by identifying the massive sandstone above it * at the typical locality as the Morgantown.

This coal attains a thickness of 4 feet in Somerset County, Pennsylvania, and has there been mined to a considerable extent for local use.

In Westmoreland, Fayette, and Alleghany it seldom exceeds 2 feet, and is generally less, but quite persistent.

In Preston County, West Virginia, north from Cheat River, this bed has been mined to a considerable extent and is known as the "top vein." In the summits near Bruceton it is 4 feet thick and a rather good coal.

At Morgantown it is nearly 4 feet thick, but rather poor and slaty.

South from Monongalia County, it is occasionally seen, but is not so 
thick as at the northern end of the field. At Glenville, Gilmer County, it is in the bed of the Little Kanawha River, and 18 to 20 inches thick.

The same coal is also recognizable on the Big Kanawha, but is there quite thin. In the section (48) at Huntington, West Virginia, Mr. Selby finds this coal 2 feet thick but very slaty.

It is not often reported by the Ohio geologists, and hence may frequently be absent from the measures in that State.

THE FLK LICK LIMESTONE.

In sections 37 and 43 , a limestone is seen at a short interval below the Elk Lick coal, and from its occurrence at this horizon in Somerset County, Penusylvania, it has been termed the Elk Lick limestone by Mr. Franklin Platt, of the Second Geological Survey, Pennsylvania. The stratum in question oceurs at 200 to 240 feet under the Pittsburgh coal, and is not always present.

As exhibited in Somerset County, Pennsylvania, this limestone is of a light gray color, and often tinged with buff, the same being true of it in Monongalia. Platt reports it as 12 feet thick in Somerset, but in Monongalia it is only about half that, and is not persistent.

THE CRINOIDAL LIMESTONE (GREeN FOSSILIFEROUS LIMESTONE, AMES LIMESTONE).

The next step downward in the rocks takes us to a very important horizon and one which marks a change from fresh or brackish water deposits to marine conditions, for here we get abundant marine fossils for the first time in descending the column of rocks.

The bel in which these fossils occur has received sereral names. The geologists of the First Geological Survey of Pennsylvania called it the Green Fossiliferous limestone, the Ohio Survey has termed it the Ames limestone, while the Second Geological Survey of Pennsylvania has termed it the Crinoidal limestone. This latter name is so well known now in geological literature that it is probably best to let it stand, though as a synonym and geographical designation the Ames limestone may be retained.

The character of this stratum and its fossils have been admirably worked out by Stevenson, who first showed its importance as a stratigraphical horizon. It comes almost exactly midway in the Barren series, and hence it is a constant datum from which the geologist can measure either upward or downward to identify the rocks.

When once thoronghly known it can not be confused with any other rock in these measures, since it is the highest bed that contains abundant Brachiopods and Lamellibranchs, and its lithology is distinctly different from anything else. Prof. Stevenson thus aptly describes its general features: "Dark bluish or greenish gray, tough, and breaks with a granular surface much resembling that of a coarse sandstone. * * *. In all cases it is fossiliferous and contains immense numbers of crinoidal stems and spines or plates." 
Its common fossils are: Productus Nebrascensis, $P$. Prattenianus, $\boldsymbol{P}$. longispinus, P. semi-reticulatus, Hemipronites crassus, Spirifera camerata, S. plano.convexa, Athyris subtilita, Lophophyllum proliferum, Zeacrinus mucrospinus, together with the undetermined plates and stems of crinoids.

Throughout Pennsylvania this stratum comes about 275 to 300 feet below the Pittsburgh coal, and the same distance above the Upper Freeport, though occasionally this last interval is increased to 350 feet. The rock is rarely more than 2 feet thick, and often not so much, but is wonderfully persistent. Even when not present as limestone its horizon is almost invariably made known by the fossiliferous shales which accompany the bed.

Through Ohio this rock is almost continuously present from the point where it enters the State near Steubenville clear around to where it leaves it at the Kentucky line near Catlettsburg.

Opposite Steubenville the bed is $\mathbf{8}$ to $\mathbf{1 0}$ feet thick, but this is unusual, since it is only 1 to 3 feet at most points in Ohio.

The interval between this rock and the Pittsburgh coal decreases westward to 200 feet on the Ohio River at Wellsburg, and farther west in Ohio the interval still further declines to 140 feet, but where it leaves the State at the southwest it increases again and gets to be 300 feet opposite Huntington, West Virginia.

Through this latter State the limestone holds its place very regularly in the series from the Pennsylvania line southward into Harrison and Lewis Counties, and it is also present on the Volcano uplift at Burning Springs and other points, still holding its characteristic fossils. It disappears, however, in passing from this Little Kanawha region southward to the Big Kanawha, for when we come to this latter stream the fossiliferous limestone is gone, and its horizon replaced near Charleston by a thin, impure limestone which holds ouly minute fresh water forms. It is highly probable, however, that the crinoidal bed comes in again a few miles north from Charleston, since on the Big Sandy it was followed 20 to 25 miles above the mouth of that stream, and there it still retains its crinoidal phase, though getting very impure where last seeu in that valley.

THE CRINOIDAL COAL.

Immediately under the laist described limestone we very often find a thin coal bed, which seldom exceeds 18 inches in thickness, and bence is of very little economic importance. In Somerset County, Penusylvania, Mr. Franklin Plattidentified with this coal No. 8 of the Berlin (37) section, a very impure, slaty bed, occurring in several layers in the vicinity of Berlin, where it is altogether 7 feet thick, and locally known as the Platt coal. If this identification be correct, this is the greatest development the coal ever attains.

There is only one other locality besides the Berlin region where this coal has been mined to any considerable extent, and that is at 
Burning Springs, Wirt County, West Virginia. Here it was mined and used for fuel in drilling the numerous oil wells once put down there, and it is still taken out on a small scale for domestic purposes, though only 20 inches thick. Some very finely preserved fossil Brachiopods and Lamellibranchs have been obtained from the roof shales of the coal at Burning Springs, since it there comes only 2 to 5 feet below the Crinoidal limestone.

The "Weller" coal, near Wellersburg, Pennsylvania, is probably identical with this bed.

RED SIIALE BEDS.

Throughout most of the Pennsylvania and West Virginia region, the Crinoidal limestone is underlaid by very soft, red, and variegated shales, and marly clays. They make a broad red band in the soil wherever they extend, and are a great nuisance along roads and railroads, since when wet they decompose into a greasy mud, which produces many landslides and slips.

It is this stratum which causes so much trouble to the oil and gas drillers of southwestern Pennsylvania and the adjoining regions of W est Virginia, since it is so easily reduced to mud, which runs into the hole and fills it up, so that casing must be put through the stratum as soon as the drill has penetrated it. From this tendency to slide out into the drill hole, it is termed by the oil drillers the "caving" rock.

Over a large portion of Ohio and in many regions of West Virginia a hard, bluish gray limestone, not at all or but sparingly fossiliferous, occurs near the center of this shale interval. The bed is 3 to 10 feet thick, and in Ohio is generally called the Ewing limestone. It is shown in the West Virginia sections at Burning Springs (47) and at Huntington (48), and it is recoguizable at many other points in the State.

The rest of the Barren Measures from this red shale down to the Mahoning sandstone is extremely variable. Sometimes it is nearly all shales, much of which is red, and "caves" in drilling through it, just like that under the Crinoidal limestone, and again as in the Berlin section (37) it contains 3 or 4 coal beds, and as many limestones. Some of these, however, are rather persistent and will be referred to in detail.

TIIE BAKERSTOWN COAL.

At some localities in western Pennsylvania a bed of coal is found 75 to 90 feet under the Crinoidal limestone. This bed is mined in the vicinity of Bakerstown, Alleghany County, and it has been designated from that village. As there exhibited, it is not quite 3 feet thick and rather slaty. In the Berlin region a coal called the Price bed seems to come at this horizon. It is about 4 feet thick and furnishes some valnable fuel in Somerset County.

In Section 37 will be found some thin coal beds under the Price coal, which are rarely represented in any other section of the Barrens. 
Among these are the Coleman, Philson, and the one a few feet under the Price bed; but they are all local, though occasionally we find traces of some of them in other regions than Somerset County. This whole interval for 100 feet below the Crinoidal limestone is so extremely variable that the classification for one region is of very little use in another. An instance of this is seen at Saltsburg, Pennsylvania, where a great sandstone 100 feet thick comes into the series a few feet under the Crinoidal limestone horizon. This was termed the Saltsburg sandstone by Stevenson, but it is hardly persistent enough to classify as a regular member of the Barrens. In the Charleston, West Virginia, region a massive pebbly sandstone occurs not far from the horizon of the Saltsburg rock, and the one which caps the hills at the mouth of the Big Sindy River may be identical with the same bed.

THE CAMBRIDGE LIMESTONES.

At many localities in Ohio two dark fossiliferous limestones occur only 20 to 30 feet apart, and Prof. Orton, director of the Ohio Geological Survey, has named them respectively the Upper and Lower Oambridge limestones. In Ohio these beds generally oceur from 90 to 130 feet under the Crinoidal limestone and are always very fossiliferous.

In many regions of Pennsylvania two dark fossiliferous limestones occur, which correspond to the two in Ohio, only there they are 60 to 70 feet apart, and the upper one 90 to 120 feet under the crinoidal bed, while the lower one is $\mathbf{1 5 0}$ to 190 feet below the same horizon. I have identified the two in Pennsylvania with the two in Ohio, and have also adopted the Ohio names, since the Pennsylvania beds are known under several names in different parts of the field, while the Ohio names are now well established. The upper one is the lighter colored of the two, and while generally fossiliferous, the fossils are not so abundant as in the lower limestone. This upper one was termed the Pine Creek limestone in my Report $\mathbf{Q}$ of the Pennsylvania Survey, while in Somerset County it seems to be identical with the Coleman limestone of Platt.

At Morgantown, West Virginia (Section 42), this bed is dark, quite fossililerous, and lies $85_{2}^{1}$ feet below the Crinoidal limestone.

The term Black Fossiliferous limestone of the First Pennsylvania Geological Survey Reports was probably applied quite as often to this npper rock as to the lower one, since at times they very closely resemble each other, and contain practically the same fossils.

The interval separating the two limestones is generally shale in Ohio, but Pennsylvania it is sometimes a massive sandstone, and 60 to 90 feet thick.

The Lower Cambridge limestone is identical with the one termed Brush Creek limestone by the writer in Report Q, Second Geological Survey of Pennsylvania, but the geological horizon of that limestone was there placed lower than it should have been by 50 to 60 feet, since it was cousidered to belong between the two members of the Mahoning 
sandstone, instead of above both members, and hence the term Brush Creek limestone should be dropped from the nomenclature, and Lowen Cambridge substituted. This lower limestone is very fossiliferous, often being a mere mass of Brachiopods and Lamellibranchs, of which the most.common are Chonetes mesoloba, Athyris subtilita, Pruductus Nebracensis and a large Solenomya, together with Nautilus occidentalis and Orthocercus cribrosum.

This bed seems to be quite as persistent in Ohio as the Crinoidal limestone, since it is present in almost every section at the proper horizon, from Steubenville clear around to Ironton, near which latter point it is only 75 feet above the base of the Barrens.

In the hills at Catlettsburg, Kentucky, a dark fossiliferous limestone occurs at 160 feet above the Upper Freeport coal, but this is probably the Upper Cambridge, and the same limestone occurs in the summits of the hills opposite Lonisa, Kentucky, at 200 feet above the Upper Freeport bed. It is barely possible, however, that this may be the Lower Cambridge limestone, since the Barrens thicken very rapidly sonthward from their northwestern ontcrop. In the Berlin section, (37), the Lower Cambridge limstone appears to be represented by the Philson limestone of Platt. The "calcareo-siliceous rock" of Hildreth, in Ohio, appears to represent the same bed.

TIIE MASONTOWN COAL.

At an interval of 5 to 20 feet below the Lower Cambridge lime. stone there occurs a coal bed which has quite a wide distribution. It attains its best development in the region of Masontown, Preston Counts, West Virginia, and it has been designated from that village. It is there, and at many other points in the Preston basin, mined for domestic purposes, being known as the "4-foot" bed, and is a dry, open-burning coal, highly prized for domestic fuel. It is everywhere preferred to the Upper Freeport, which is accessible in the same region.

This appears to be the same bed which the writer described in Report $Q$, Second Geological Survey of Pennsylvania, under the name of Brush Creek coal, since a diamond drill hole has recently shown that the Brush Creek bed lies 135 feet above the Upper Freeport coal instead of 75 , as formerly supposed, and hence it is deemed best to drop the name Brush Creek altogether for both the coal and the limestone. This Masontown coal is generally the first one above the top of the Mahoning sandstone, and the interval separating it from the latter varies from 5 to 50 feet. Very frequently the coal is only one-half to 1 foot thick, aud sometimes it is represented only by black slate.

Near Gallitzin, Pennsylvania, it is seen in a cut on the old Portage Railroad, where it is only one-half foot thick, but it is overlaid by 3 to 4 feet of black slate. The coal is here 140 feet above the Upper 
Freeport coal as measured in the McCoy shaft, which starts at the horizon of the Masontown bed.

This coal is reported as present at many localities in Ohio, though there it seldom exceeds 2 feet in thickness. It is probably this bed which has been opened near the summit of the hill opposite Louisa, Kentuck5, where it is. 2 feet thick and rather slaty,

In the Belington basin, Barbour County, West Virginia, this coal attains a fiue development and is often 4 to 5 feet thick with 6 inches of bony coal near the center.

THE IRONDALE LIMESTONE AND ORE.

Directly under the Masontown coal there is occasionally found a bed of buffish gray limestone, which at Irondale, Preston County, West Virginia, and adjoining regions, is accompanied by a bed of iron ore immediately under the limestone.

When the ore is present, however, the coal above is generally absent, as is the case at Irondale and Gladeville, Preston County, where the ore has been used to a considerable extent. It varies in thickness from 1 to 2 feet, and is rather siliceous, there being only about 38 per cent of metallic iron in the ore. It comes 155 feet above the Upper Freeport coal, and hence its horizon is assigued to that of the Masontown coal, since the interval agrees, and then a similar limestone 3 feet thick is seen under the coal at Albright and other localities in Preston County.

THE MAHONING SANDSTONE.

This is the lowest sandstone deposit of the Barren Measures, and although at times consisting of one solid rock, yet it is generally complex. The usual rule is for the mass to divide into two sandstones, an Upper and Lower Mahoning, each 40 to 50 feet thick, with a shale interval between containing a coal bed and limestone or iron ore, but sometimes when the group reaches a great development, as on the Big Kanawha (Section 49), it contains three coal beds, and as many sandstone divisions. This is exceptional, however, the normal structure having only two saudstones with one included coal, the whole series being 100 to 150 feet thick.

The wild scenery and poor soil of the lower portion of the Barrens are largely due to these sandstones. Being frequently quite hard and even pebbly, they cap the hills long after all the other members of the Barrens above have disappeared, and they have thus protected the underlying Lower Coal Measures over wide areas where the latter wonld otherwise have been carried away by erosion.

In Wyoming County, West Virginia, they cap the summits of Guyandotte Mountain at an elevation of 3,000 feet above the sea. Much of the Lower Coal Measures between that mountain and the Great Kanawha River would have been swept away but for this massive coping.

It is the same friendly cover that has preserved large areas of the 
Coal Measures on the summits of the Alleghany Mountains, and in isolated basins like Broad Top. The great tunnels on the Pennsylvania and Baltimore and Ohio Railroads, Gallitzin and Kingwood respectively, pass under domes of this sandstone group. Some portious of this sandstone nearly always furnish good building rock, the Government locks on the Great Kanawha being constructed of it. The same stone is also largely quaried along the Ohio River hills in Beaver County, Pennsylvania.

The Upper Mahoning is generally more massive than the Lower one, and is the conglomeritic member, since it is often a mere mass of quartz pebbles, having once been quarried for mill stones on Cheat River near Morgantown. In the Great Kanawha region this rock is extremely hard and siliceous, and at many points a mere bed of pebbles, some of which are as large as an egg.

THE MAIIONING COAL.

This is the coal bed which is so often bound up between the two great divisions of the Mahouing sandstone. It was formerly called the Brush Creek by the writer, hut as the place of that coal was misunderstood, it is thought best, as already stated, to drop the name en. tirely, and replace it with the name Mahoning, since it comes in the middle of the Mahoning sandstone. It is possible that the Gallitzin coal of Platt in Cambria and Blair Counties may belong at this horizon, but owing to the uncertainty comnected therewith it has been deemed best not to adopt that name.

This is a very widely distributed coal bed, and frequently attains commercial importance. It is the coal No. 7 of the eastern Ohio series, where it is 3 feet thick and very excellent fuel. It is mined at many localities in Ohio, as well as in Pennsylvania.

On the Great Kanawha River, a few miles above Charleston, this bed swells out to a thickness of 17 feet in the vicinity of Coalburg; but much of this is slate and bone, there being only 5 to 6 feet of good coal in the bed. There is probably a considerable area of this coal of merchantable thickness in the region sonthwest from the Great Kanawha, since it is several feet thick along the summits of ridges in the Huff Creek Mountains, at the sonthern line of Logan County, and the same bed is 5 feet thick along the Tug branch of Big Sandy, and in the Peach Orchard region of Kentucky, where it occurs 235 feet above the Peach Orchard bed (Winnifrede). The coal is quite hard, and in many places a "block" coal through this southwestern region. The interval of this berl above the base of the Barren Measures varies from 50 to 175 feet, this latter being the figure at Coalburg and Peach Orchard.

THE MAHONING LIMESTONA.

Occasionally a limestone comes into the series immediately under the Mahoning coal. In Beaver County, Pennsylvania, it is often 5 to 8 feet 
thick, and is locally termed the "Summit" limestone. It is not a persistent bed, being much less so than the coal of the same name above, and when present it is often impure and ferriginous. In fact it is occasionally an iron ore, the Johnstown ore of Penusylvania being identical with this stratum.

THE UPPER AND MIDDLE CANNELTON COALS.

Along the Great Kanawha, where all of the measures hare thickened up so abnormally, two other coal beds make their appearance in the Barren series below the Mahoning coal, and they have been termed the Upper and Middie Cannelton, from a locality on the Kanawha where both are exposed. The former has there been mined for a long time in "the summit of the hills, where it furnishes 5 feet of excellent "block" coal. It comes 90 feet above the base of the series, but the interval constantly decreases northward, and at Charleston is only $\mathbf{4 0}$ to $\mathbf{5 0}$ feet. As this interval decreases the coal becomes inferior, until at Charleston it is represented by some coaly streaks only, about the middle of the Lower Mahoning sandstone.

The Middle Cannelton coal never attains commercial value, and is found only in the region of Canneltou and southward. It is slaty, worthless, never more than 3 feet thick, and comes 20 to 25 feet above the base of the Barrens.

The Lower Mahoning sandstone is generally of a bluish gray color, quite homogeneous, and often an excellent building stone. Though occasionally contaiuing pebbles, it is much freer from them than the Upper Mahoning. The thickness varies from 30 to 50 feet, except in the Kanawha region, where it splits up into two or three divisions, and is more than 100 feet thick.

The shales which separate the Upper and Lower Mahoning sand. stones are sometimes red, or variegated, as in the Sewickley section (34); and, occasionally, as in the vicinity of Tunnelton, Preston County, West Virginia, guod fire clay occurs at the horizon of the Mahoning limestone.

Both members of the Mahoning sandstone are occasionally oil-pro. ducing, but more generally the upper one, this being the main oil rock at Bobtown, on Dunkard Creek, Greene County, Pennsylvania, and on Whitely Oreek. It is known to the oil producers as the "Dunkard sand," and it is also oil-bearing in the Macksburg and other regions of Ohio.

The shales which usually intervene between twe base of the Mahoning sandstone and the Upper Freeport coal often contain fossil Brachiopods and Lamellibranchs, as well as the common coal measure plants. They are quite variable in thickness, the Lower Mahoning sometimes cutting out the shales entirely and-resting on the Upper Freeport coal, while again the shales may thicken up to 50 feet.

$$
\text { Bull. } 65-7
$$


THE KANAWHA BLACK FLINT.

In the midst of the shales at the base of the Barrens, and apparently at the horizon which usually contains the marine fossils, there occurs along the Great Kanawha River a peculiar dep"sit, known locally as the "Black Flint." It makes its appearance in the section first at Cbarleston, and occurs from there sonthward along the river until the Barrens disappear from the summit of Gauley Mountain, 50 miles dis. tant.

The distribution of the flint appears to be confined to a belt along the river 10 to 12 miles wide, since at 5 to 6 miles back on either side it generally disappears from the section, so as to be no longer recognizable. It is not confined to the Kanawha region however, since the deposit is visible near Clay Court House, on Elk River, and near the California House, on the crest of the Burning Springs anticlinal, where it crosses Hughes River at the corner of Wirt and Ritchie Counties. The rock varies from 5 to 15 feet in thickness, and is usually of a dark or bluish black color, though at the California House it is light colored. Being almost indestructible by atmospheric agencies, it has played a conspicuous part in shaping the topography in the Kanawha region, since it protects the underlying beds from erosion. Through the agency of heat and cold it finally breaks down into oblong and rudely rectang. ular blocks which everywhere line the beds of streams and cover the surface below the line of outcrop. The Indians manufactured arrow heads and other implements from this material, so that pieces of it have been found as far north as Pennsylvania. It is evidently a marine deposit, since it is distinctly stratified, and specimens of Discina, Spi. rifera, and Productus are common in the less siliceous layers. The flint is evidently derived from the skeletons of diatoms and protozoa, though no microscopic examination has been made. 
C H A P T E R V.

THE LOWER COAL MEASURES, OR ALLEGHANY RIVER SERIES.

THICKNESS, CHARACTER, AND EXTEN'T.

Below the Barren Measures or Elk River series there occurs a group of rocks (No. XIII) which always holds valuable coal beds. From the fact that they are finely exposed along the Alleghany River, they were long ago called the Alleghany River series, and their geological position in the general scale of the Carboniferous gave them the name Lower Coal Measures. The discovery in recent years that the next lower group of beds (the Pottsville Conglomerate) sometimes holds workable coal, has been used as an argument by some geologists for breaking up the old nomenclature and rearranging the Carboniferous into new groups, but this nomenclature is so convenient, and expresses the natural divisions of the rocks so well, that it would be very unwise to make any such changes as have been proposed, since it would be of no particular service and would only bring confusion to the minds of many people interested in Carboniferous geology who are now thoroughly conversant with the old and tried nomenclature of Pennsylvania and Virginia. Hence, while for strictly scientific purposes it may be well to group the Carboniferous rocks on a wider basis as proposed in a former part of this report, yet for every day field work in practical geology, the old nomenclature can not be improved upon.

The Lower Coal Measures, as now limited, begin at the top with the widely distributed and valuable Upper Freeport coal bed (a horizon which is easily recognized anywhere by the field geologist) and extend down through several beds of shale, limestone, coal, and sandstone till a horizon is reached where a marked change in lithology takes place, the sandrocks becoming harder, more massive, and often pebbly, accompanied with a corresponding change in the character of the imbedded fossils.

The thickness of this series varies greatly in different portions of the field, being not far from 300 feet in western Pennsylvania, and seldom less than 250 feet anywhere in that State; except in the Broad Top field. But westward through Ohio the thickness of these measures declines until around the northwestern border of the field it is less than 200 feet. Southward from this region of Ohio, where the Lower Coal Measures are thinnest, they thicken up rapidly until on the Great Kanawha River the series is 1,000 feet thick, and the same on the Guyan- 
dotte and 'Tug Rivers. Just where this great thickening up begins in going southwestward from the Pennsylvania line is not exactly known, but there are good reasons for believing that much the greater portion of it takes place beyond the Little Kanawha River.

The topography made by these rocks is generally very much the same, except where the thickness is very great. It is nearly everywhere characterized by a hilly country, terraced with a series of parallel benches which, as Lesley long ago showed, mark the outcrops of the several coal beds, since the soft rocks usually found with every coal are more rapidly eroded than the harder ones above or below. These coal benches are not confined to the topography of the Lower Coal Measures, since they are due to a general law of erosion, but are only more conspicuous in this series because the coal beds are more numerous and closer together.

Through Pennsylvania, Ohio, and the northern half of West Virginia, with few exceptions, the hill slopes of these measures, while often rather steep, are not too rugged for good arable aud grazing lands, and the soils are usually rich; but in the southwestern part of West Virginia, where these rocks have increased in thickness so largely, we find a network of narrow ridges, generally capped with the Mahoning sandstone, from which the surface falls a way at an angle of $25^{\circ}$ to $40^{\circ}$ to the beds of the streams, 1,000 or more feet below, thus practically confining the arable land to the narrow valleys, which are frequently trenched into the top members of the next uuderlying or Pottsville series of rocks.

It was formerly supposed that this series held valuable coal only in a broad belt around the margius of the coal field, and that in the cen: ter of the Appalachian basin, where these beds are buried under 1,500 to 2,000 feet of superincumbent strata, they contained no coals thick enough to mine; but the receut drilling of many oil and gas wells over the central portion of the field has proved the supposition to be un: founded, for the drill has many times penetrated thick beds of coal in this series at localities where they underlie the surface by an interval of more than 1,500 feet. Hence, aside from local irregularities always to be found in any coal field, there is no reason for believing that the Lower Coal Measures do not contain one or more good coal beds under nearly every portion of the Appalachian field, and where it would seem to be otherwise the inference has been founded largely on defective records of borings, in wbich no attention was given to the character of the beds encountered unless they proved to be "sands." But while it is true that recent drilling has shown valuable coal in this series along the central portion of the trough where it was formerly supposed to be abseut, yet it is true as a general law that the coal beds of this series are thicker and better and more numerous around the margins of the Appalachian field than toward the center. This is illustrated by the 


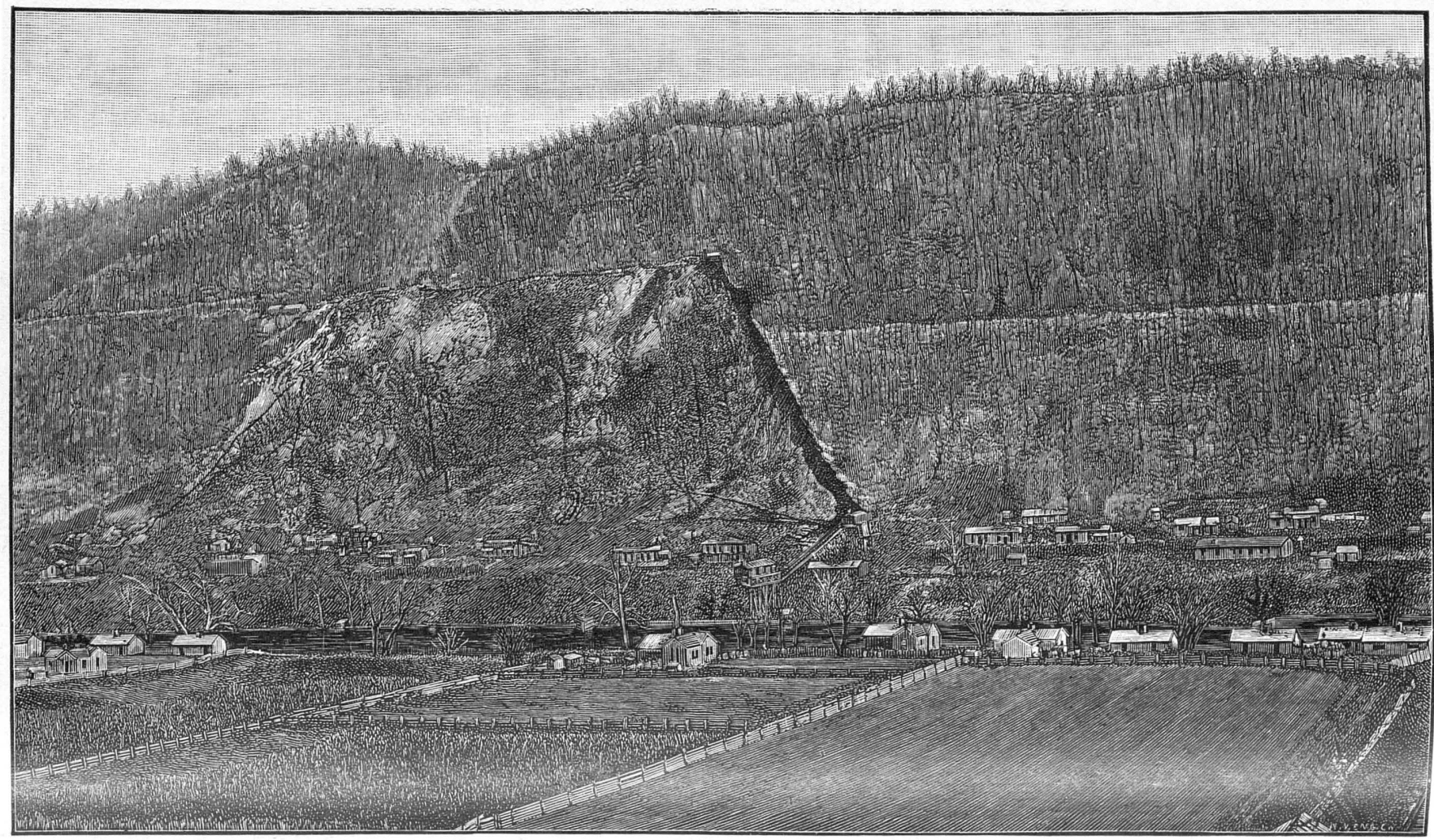

LOWER COAL MEASURES, COALBURG, KANAWHA RIVER, WEST VIRGINIA. 

distribution of the Clarion and Brookville beds, which are valuable only around the margin of the coal area.

Owing to the geological position of the Lower Coal Measures, their beds have a much wider spread and are accessible over a larger area than those in the Upper Coal Measures, so that when in the distant - future the upper coals and the easily accessible areas of the lower ones shall have been exhausted, there will still remain far down in the trough of the Appalachian field a great wealth of fuel which can be obtained by deep shafting. It is true that at many localities disclosed by the drill only one good bed of coal has been found in this series where it lies so deep beneath the surface, but that is also true of the surface outcrops, and many places can be found where not even one good coal bed occurs in the surface section, and many others where two are the exception.

The main strata of this series, which have been recognized and traced over a wide area in the three States with which this report deals, have received the following names in descending order:

Upper Freeport coal.
Upper Freeport limestone.
Upper Freeport sandstone.
Lower Freeport coal.
Lower Freeport limestone.
Lower Freeport sandstone.
Upper Kittanning coal.
Johnstown (Cement) limestone.
Middle Kittauning coal.

Lower Kittanuing coal.

Lower Kittauning fire clay. Lower Kittanning sandstone. Bubrstone iron ore. Ferriferous limestone. Putuam Hill limestone. Clarion coal.

Brookville coal.

Other beds have been named in this series which have a local distribution, but those given above are the main ones which can be traced and identified over wide areas.

Prof. Orton, director of the Ohio.Geological Survey, has shown that all of the main beds of the Pennsylvania Lower Coal Measures can be followed and identified entirely across the Uhio coal field to where they enter Kentucky; and the writer has recently shown (The Virginias, 1885) that they also stretch unbroken around the southeastern margin of the Appalachian field, from the Pennsylvania line down through West Virginia to the Great Kanawha, and on across the Guyandotte to the Big Sandy, so that the identifications of the main beds of coal, limestone, and sandstone of the Lower Coal Measures have now been carried from Pennsylvania to the Kentucky line, on both sides of the Appalachian field.

As illustrations of these measures, in most of the important coal regions of the area in question, we shall now present a number of vertical sections. The identitications of the several beds in these sections have been made with all the care and light at present attainable, and while it is not claimed that they are final in all cases and free from error, yet they express the best efforts of the writer, and it is confidently believed 
that their publication will serve to stimulate a more careful study of the general stratigraphy by field geologists and those interested in mining enterprises, so that finally whatever of error may be embodied in these identifications will be discovered and eliminated. It is certain that the first effort to harmonize the stratigraphy over such a large area will be somewhat provisional, and hence the writer not only ex-" pects, but welcomes, the kindly criticism of his brother geologists, knowing that all will be pleased when the true order and succession of these beds are definitely determined in the several important regions of the Appalachian field.

In some cases, like that at Blossburg, where it has been impossible to identify the main coal beds with any degree of certainty, the writer has given only the local names for the beds, leaving the reader to draw his own conclusions from the general structure of the section; but there are very few cases where some one of the seams in a given section can not be reasonably determined.

We shall begin these illustrations of the Lower Coal Measures at the most northern point of the Appalachian Basin, and proceed southwestward through the field.

Section at Blossburg, Pennsylvania.-The structure of the Lower Coal Measures at the northern end of the Appalachian basin is given as follows (Fig. 50) for the Blossburg region, Tioga County, Pennsylvania, by the First Geological Survey of Pennsylvania, Final Report, Vol. II, page 520 :

Blossburg, Tioga County, Pennsylvania.

[See map, B w.]
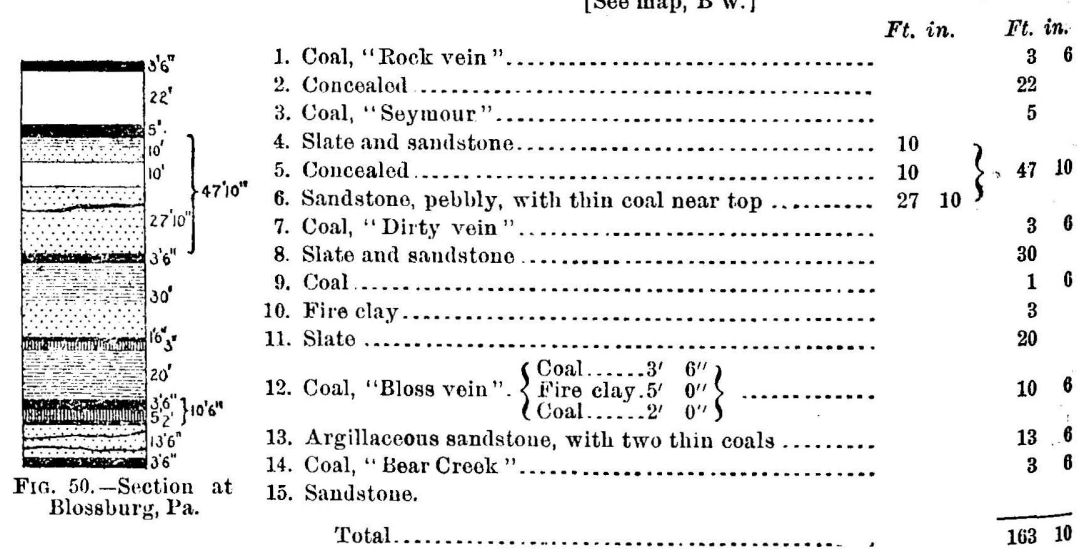

The "Bloss vein" seems to be identical with the Lower Kittanning bed of the Alleghany River, while the "Rock vein" and "Seymour" are possibly identical with the Upper and Lower Freeport beds, respectively. This would make Nos. 7 and 9 the Upper and Middle Kittan. ning. 
Section at Fall Brook, Pennsylvania.-At Fall Brook, 8 miles northeast from Blossburg, and the most northern development in the Appalachian coal field, the structure of the Lower Coal Measures is given as follows (Fig. 51) by Mr. Franklin Platt, in Report G, pages 166, 169, Second Geological Survey of Pennsylvania:

Fall Brook, Tioga County, Pennsylvania.

[See map, B x.]

1. Coal, "Seymour"

2. Rough, sandy fire clay

3. Saudstone, massive, pebbly

4. Coal

5. Fire clay

$\{$ Sand

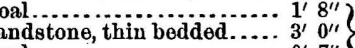

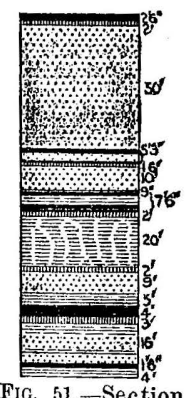

Fic. 51.-Section at Fall Brook,

6. Sandston

Coal......................... $\left.0^{\prime} 7^{\prime \prime}\right\}$

7. Slat

(Coal... $\mathbf{1}^{\prime}, 3$

8. Coal, "Dirty vein" $\begin{array}{lll}\text { Slate. } & 4^{\prime} & 0^{\prime \prime} \\ \text { Coal. } & 1^{\prime} & 2^{\prime \prime}\end{array}$ Slate. $0^{\prime} 3^{\prime \prime}$

9. Rough, hard fire clay

Coal. . $0^{\prime} 10^{\prime \prime}$ .

11. Fire clay, with

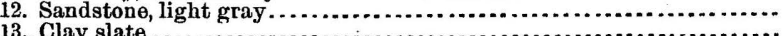

13. Clay slate.

14. Coal, "Bloss vein"

15. Fire clay, pure

17. Coal and slate, "Bear Creek"

19. Sandstone.

Total

Section near Karthaus, Pennsylvania.-About 65 miles southwest of Blossburg, in the northeastern corner of Olearfield County, Pennsylvania, the following section (Fig. 52) of the Lower Coal Measures is reported from the vicinity of Karthans, by H. D. Rogers, in the First Geological Survey of Pennsylvania :

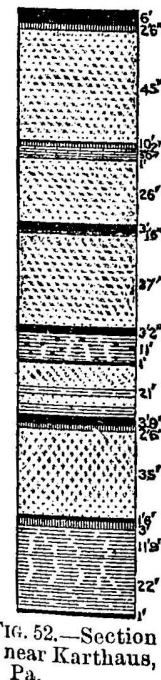

\section{Karthaus, Clearfield County, Pennsylvania.}

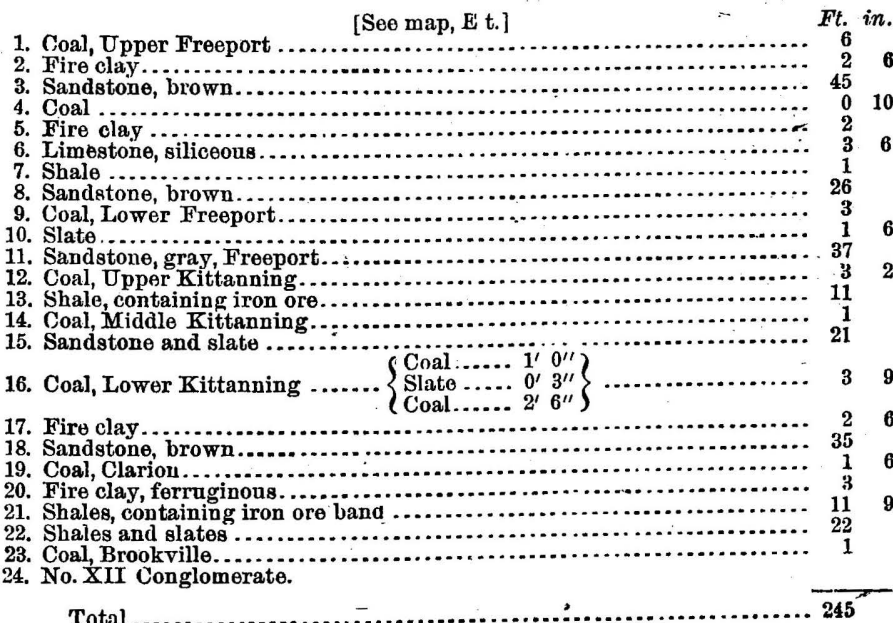

near Karthaus 
Section in Horton Township, Elk County, Pennsylvania.-Horton Township, Elk County, Pennsylvania, lies on the borders of Clearfield and

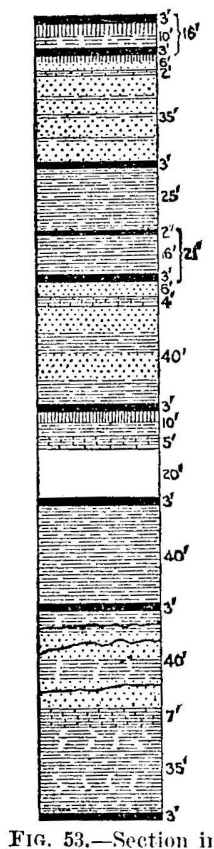

(19. - Section in Jefferson Counties, 30 miles west from Karthaus and about 80 miles distant west southwest from the Bloss. burg region. In this township Mr. C. A. Ashburner finds the following section (Fig. 53) for the Lower Coal Measures, Report RR, page 227:

Horton Township, Elk County, Pennsylvania. [See map, D q.]

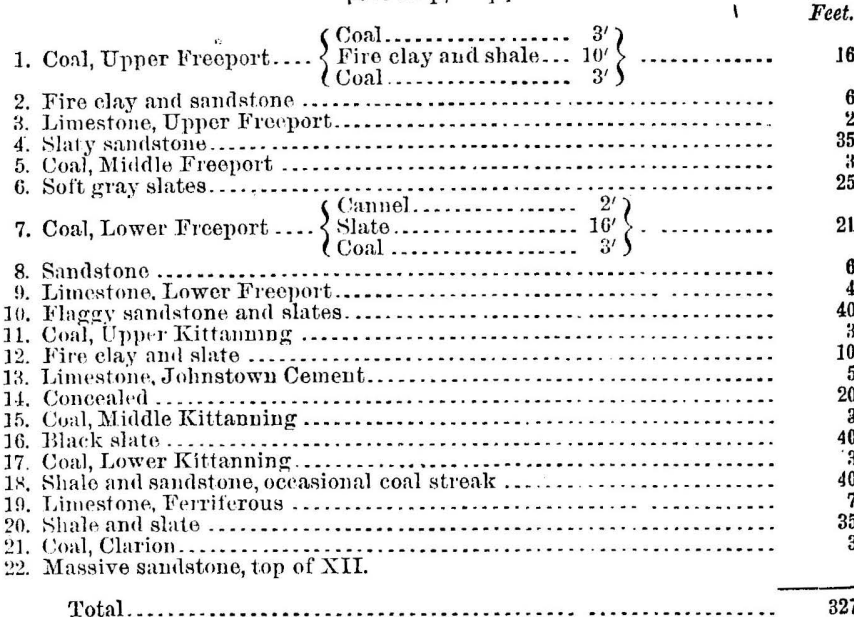

Section near Brockwayville, Pennsylvania._Snyder Township, Jefferson County, adjoins Horton, and there, near Brockwayville, Mr. Wm.

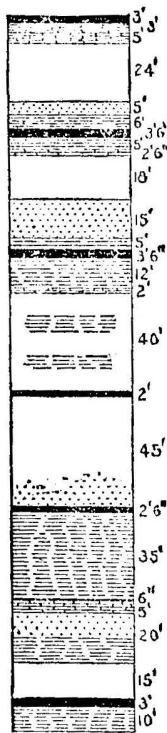

Fis. 54-Section near Brockway. ville, $\mathrm{Pa}$.

G. Platt reports the following structure (Fig. 54) for the Lower Coal Measures, Report $\mathrm{H}^{6}$, jages 186, 187:

\section{Frockwayrille, Jefferson County, Pennsylvania.}

[sice ma], D r.]

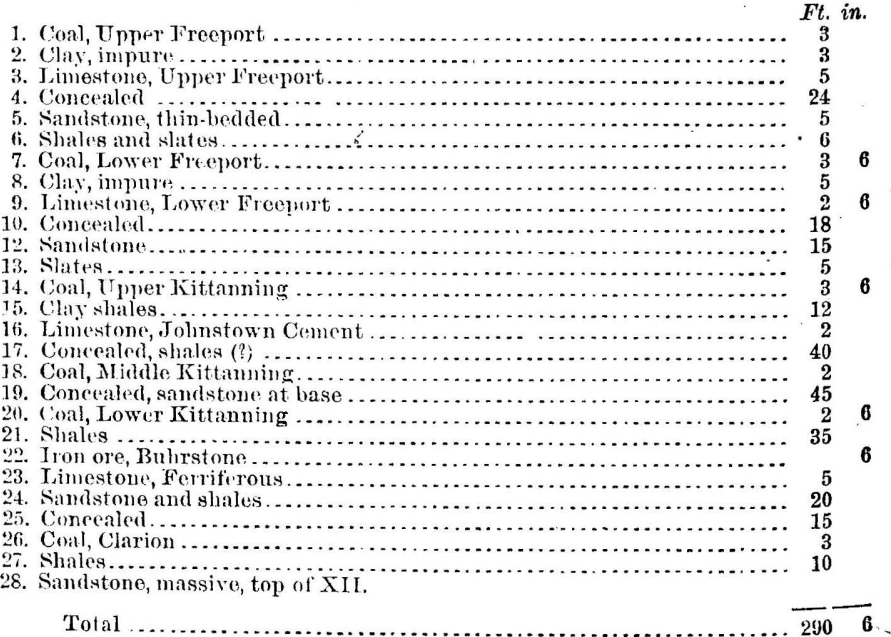


Section in Clarion County, Pennsylvania.-Clarion Connty lies next west from Jefferson, and Mr. H. Martyn Chance gives in Report VV,

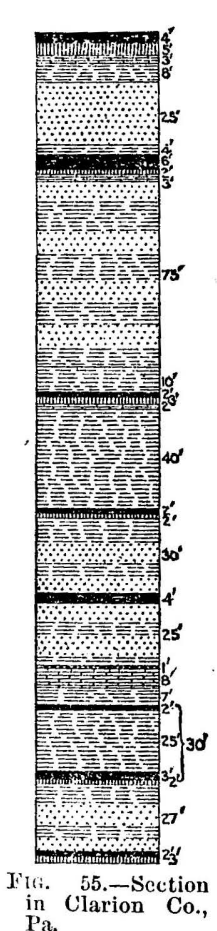
page 32, Second Geological Survey of Pennsylvania, the following as the general structure of the Lower Coal Measures in that county (Fig. 55):

\section{Clarion County, Pennsylvania.}
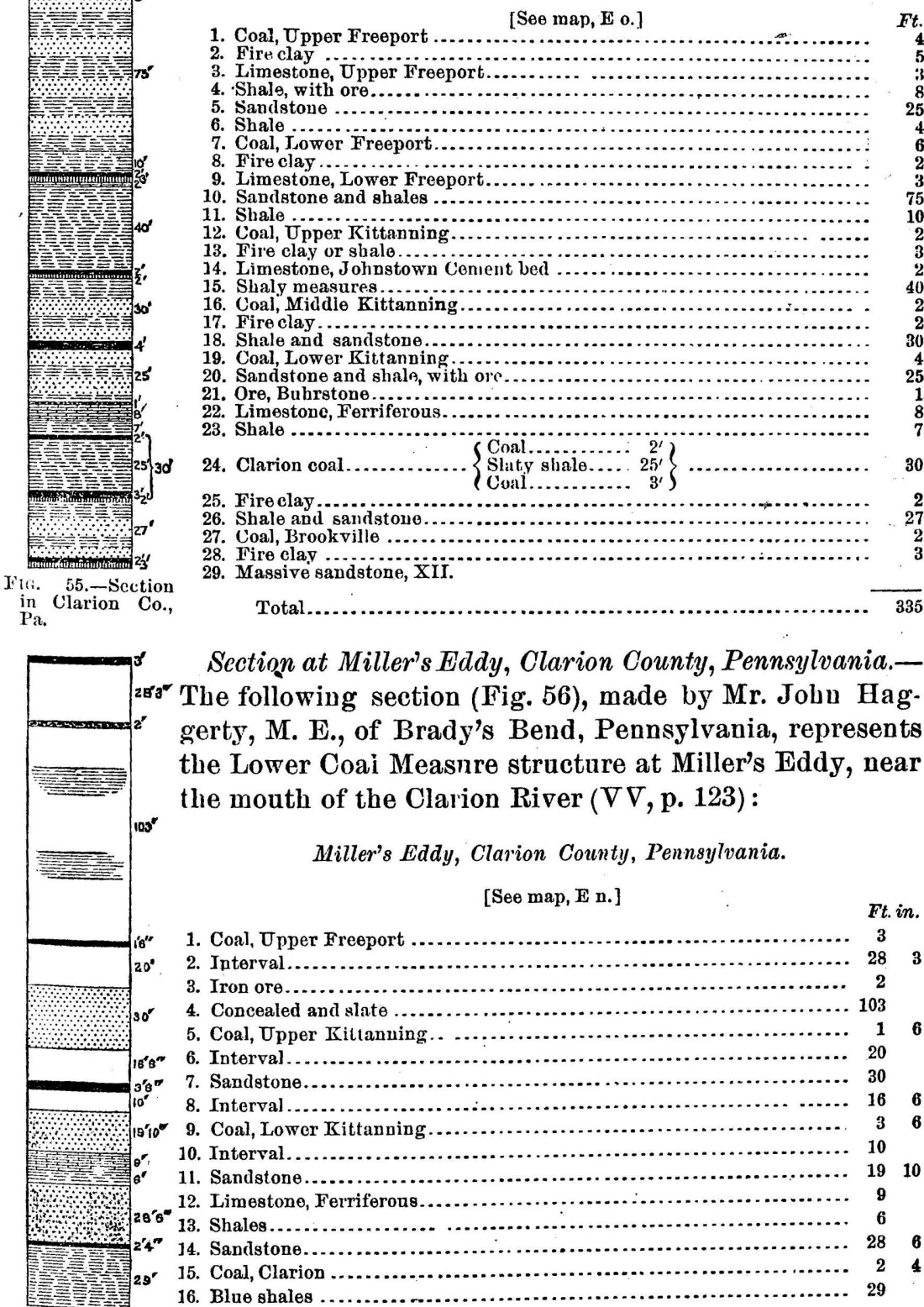

Section at Miller's Eddy, Clarion County, Pennsylvania.The following section (Fig. 56), made by Mr. John Haggerty, M. E., of Brady's Bend, Pennsylvania, represents the Lower Coai Measure structure at Miller's Eddy, near the mouth of the Clarion $\operatorname{River}(\nabla \nabla$, p. 123):

Miller's Eddy, Clarion County, Pennsylvania.

[See map, E n.]

1. Coal, Upper Freeport ......................................... 3

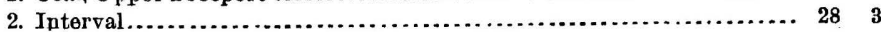

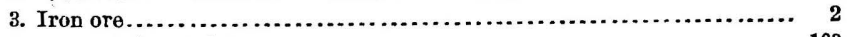

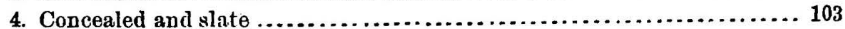

5. Coal, Upper Kittanuing. . ...................................... 19

6. Interval....................................................... 20

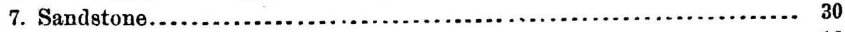

8. Interval.................................................. 16

9. Coal, Lower Kittanning........................................ 3

10. Interval........................................................... 10

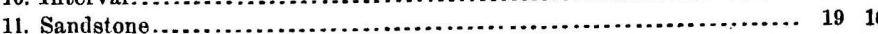

12. Limestone, Ferriferous ...................................... 9

13. Shales

14. Sandstone......................................................... 28

15. Coal, Clarion ................................................... 24

16. Blue shales ...................................................... 29

FIf. 56,_-Section 17. Sandstone, massive. 
THE NORTHERN BITUMINOUS COAL FIELD. [BULL: 65.

Section at East Brady, Clarion County, Pennsylvania.-Mr. Haggerty also lereled another section of these measures at East Brady, in the

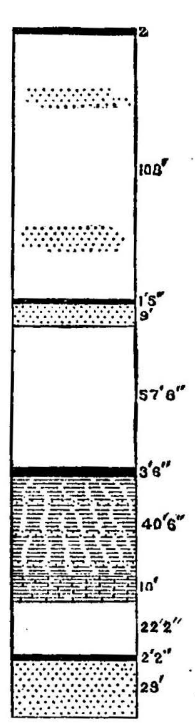

Fig. 57.-Section at East Brady; sonth western corurer of Clarion County, which is given as follows (Fig. 57) in Report VV, p. 77 :

East Brady, Clarion County, Pennsylvania.

[Seo map, F n.]

1. Coal. Upper Freeport ......................................... ${ }_{2}$

2. Concealed and sandstone.................................... 108

3. Coal, Upper Kittanning...................................... $1 \quad 5$

4. Sandstone .................................................. 9

5. Interral ................................................... 57 6

6. Coal, Lower Kittanning ..................................... 3.6

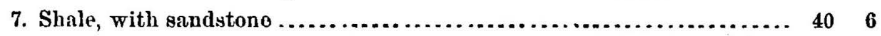

8. Limestone, Ferriferous.................................... 10

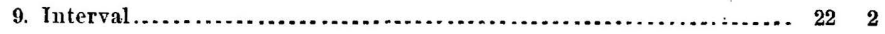

10. Coal, Clarion .............................................. $2 \quad 2$.

11. Sandstune ...................................................... 23

12. Coal, thin, Brookrille.

13. Saudstone, No. XII.

Total

Section near New Bethlehem, Pennsylvania.-Mr. Chance gives the following (Fig. 58) as the structure of the Lower Coal Measures in the

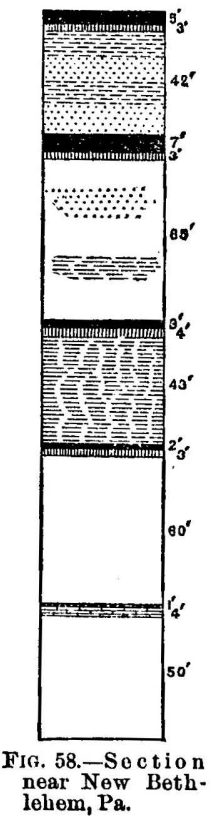
vicinity of New Bethlehem, on the Red Bank River, in southeastern Clarion County, VV, p. 88:

Near New Bethlehem, Clarion County, Pennsylvania.

$$
\text { [See map, F o.] }
$$

1. Coal, Upper Freeport

2. Fireclay -

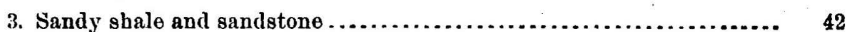

4. Coal, Lower Freeport ..................................... 7

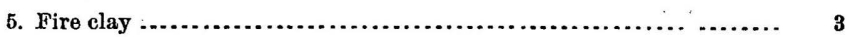

6. Concealed, sandstone, and shalo............................... 65

7. Coal, Upper Kittanning ......................................

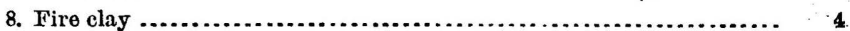

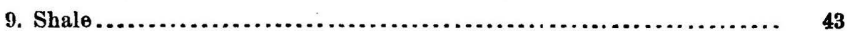

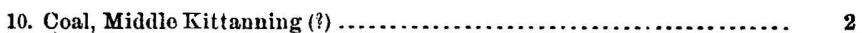

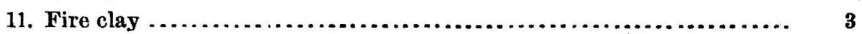

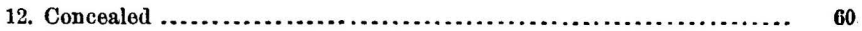

13. Ore, Buhrstone ............................................... 1

14. Limestone, Ferriferous ..................................... 4

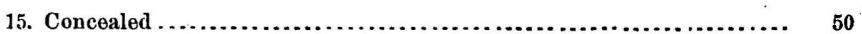

16. Sandstone, top of XII.

Total. 
Section in Brady Township, Butler County, Pennsylvania.-In the northwestern portion of Butler County (Brady Township), Mr. Chance

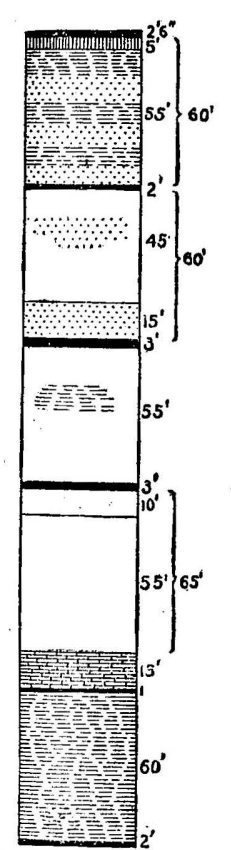
gives, in Report $\nabla$, the following section (Fig. 59) for the Lower Coal Measures down to and including the Ferriferous limestone, and the portion below that is added from an exposure in an adjoining township:

\section{Brady Township, Butler County.}

\begin{tabular}{|c|c|c|}
\hline [See map, F l.] & Ft. & \\
\hline 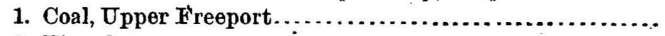 & & \\
\hline 2. Fire clay ................... & $5\}$ & \\
\hline 3. Shale and sandstone... & $55\}$ & 60 \\
\hline Coal, Lower Freeport.. & & 2 \\
\hline 5. Concealed, and massive sandstone................ & $45\}$ & \\
\hline . Massive sandstone ...... & 15 & 60 \\
\hline 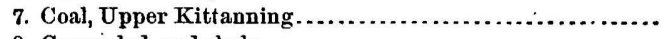 & & 3 \\
\hline 8. Concealed, and shale.... & • & 55 \\
\hline 9. Coal, Middle Kittanning (?) ........................ & & 3 \\
\hline . Concealed. & 10) & \\
\hline Iron ore........ & thin & 65 \\
\hline Concealed ........... & 55) & \\
\hline Limestone, Ferriferoụs. . & - & 15 \\
\hline Coal, Scrubgrass........ & & 1 \\
\hline Shales ........ & & 60 \\
\hline Coal, Brookville ........ & & 2 \\
\hline Tot & & \\
\hline
\end{tabular}

Section near Ore Hill Furnace, Armstrong County, Fra. 59.-Section in But. Pennsylvania.-In the vicinity of Ore Hill Furnace, ler County, Pa. Armstrong County, Pennsylvania, 3 miles below the

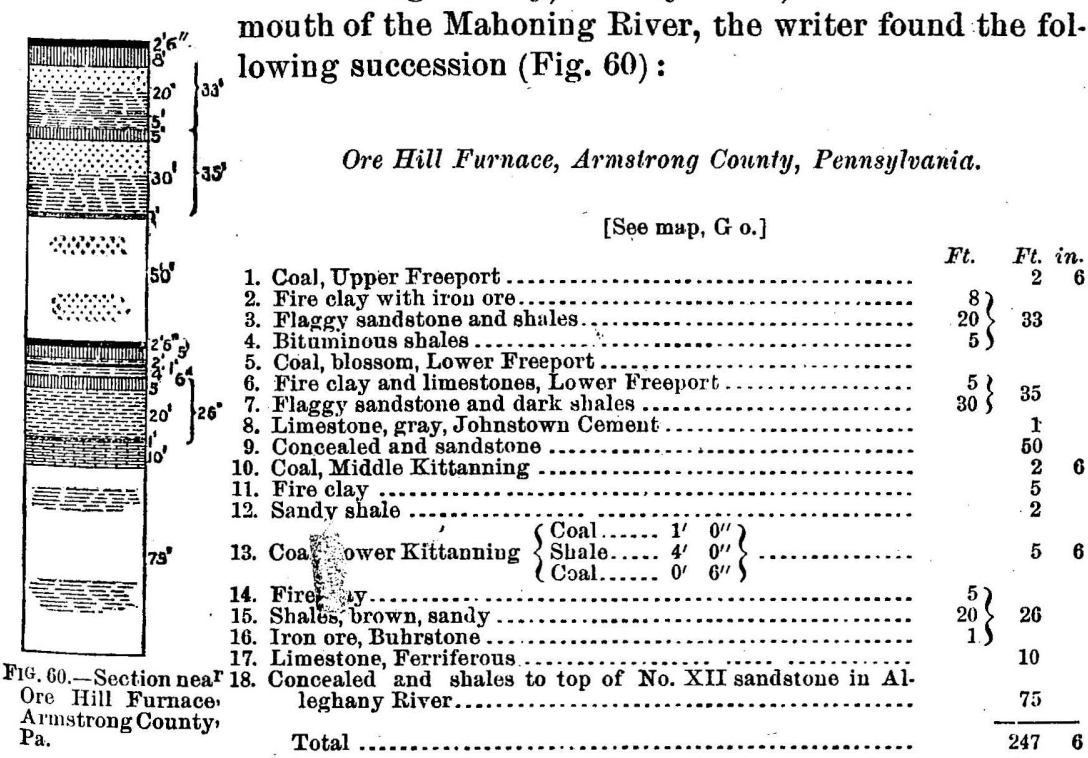

This section exhibits a rapid thinning away of the whole column, but principally in that part of it between the Upper Freeport and the Upper Kittanning coals. 
Scction near Centerville, Pennsylvania.-Five miles northeast from Oro Hill Furnace, the following succession (Fig. 61) is reported from the vicinity of Centerville by Mr. Wm. G. Platt, in Report

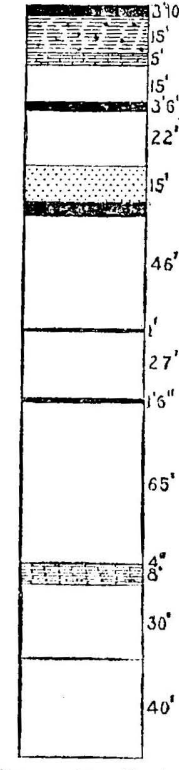

Fic. 61.-.Sectinn near Centerville, Pa.
$\mathrm{H}^{5}$, Second Geological Survey of Pennsylvania, pages 163,164 .

Centerville, Armstrong County, Pennsylvania.

[See map, G o.]

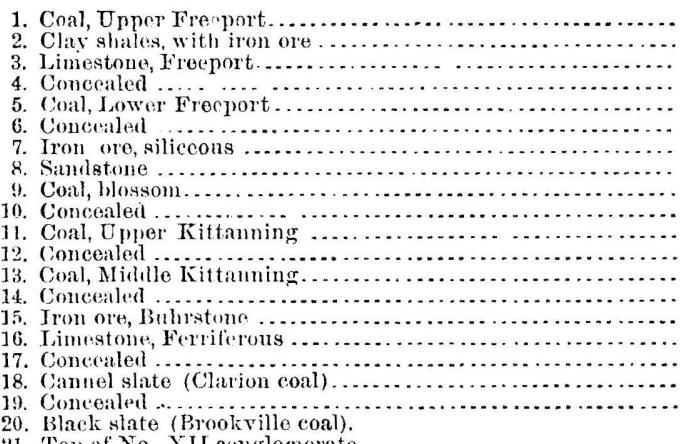

Ft. Ft. in.

$\left.\begin{array}{r}15 \\ 5\end{array}\right\} 35$

$15\} 3$

22 ) 37

15

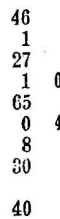

1. Top of No XII councromerate.

Total

Section at Putneyville, Pennsyloania.-Five miles east of Centerville is the village of Putneyville, and from this vicinity $\mathrm{Mr}$. Wm. G. Platt reports the following section (Fig. 62) of the series $\mathrm{H}^{5}$, p. 150 :

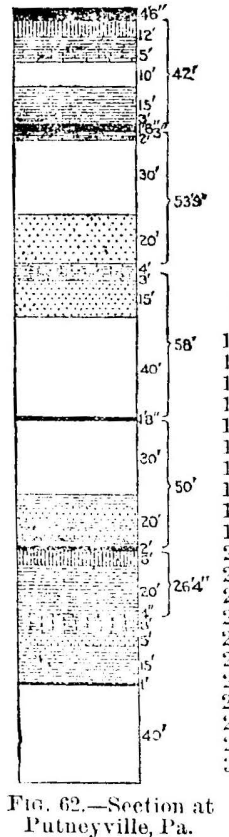

Putneyville, Armstrong County, Pennsyliania.

\section{[See map, a o.]}

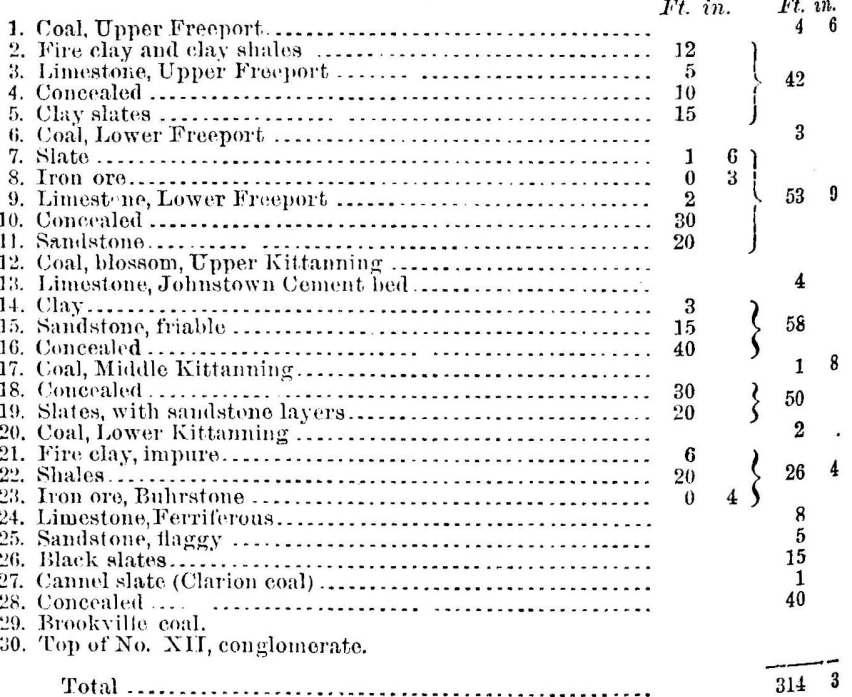


Section near Kittanning, Pennsylvania.-In the vicinity of Kittanning, Penusylvania, the succession of the Lower Coal Measures is as follows (Fig. 63):

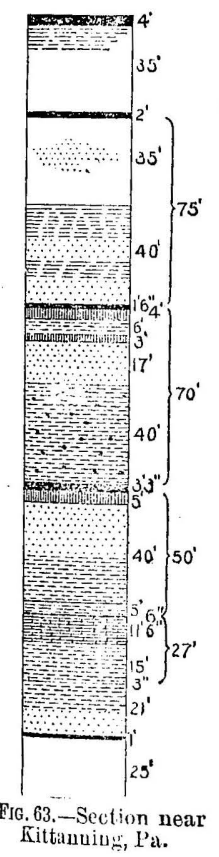

Vicinity of Kittanning, Pennsylvania.

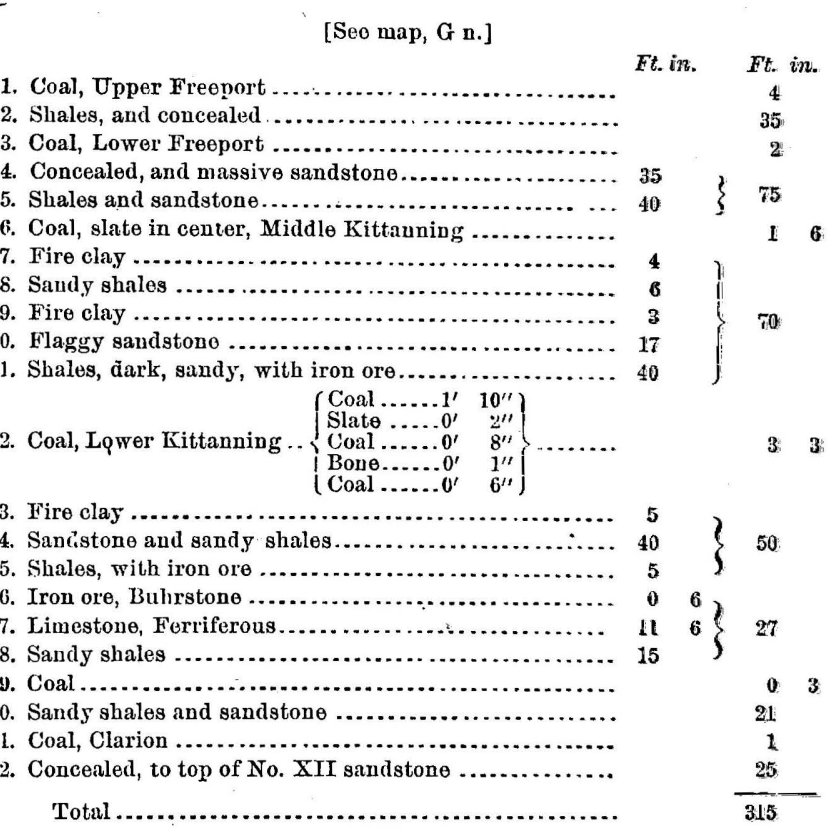

Section 5 miles south of Kittanning, Pennsylvania.-About 5 miles south of Kittanning and 1 mile below the mouth of Crooked Creek a very important exposure may be seen on the left bluff of the Allegheny River, since it gives in a clear manner the relations of the upper members of the Lower Coal Measures. The section there (Fig. 64) was carefully leveled by the writer, and reads as follows:

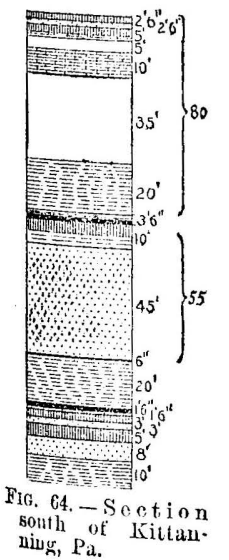

Five miles below Kitlanning.

[See map, G n.]

Ft. in. Fit, in.

1. Coal, Upper Freeport, blosson

2. Tire clay

Sandstone

4. Fire clay and shales

5. Concealer

6. Limestine, Upper Freeport...........................

7. Concealed

8. Shales, bluish........................................

9. Coal, Lower Freeport... $\left\{\begin{array}{l}\text { Coal } \ldots . . .0^{\prime} 2^{\prime \prime} \\ \text { Slato } \ldots . .1^{\prime}\end{array}\right.$

10. Fire clay and shales.... $\left\{\begin{array}{ll}\text { Coal........1 } 1^{\prime} & 8^{\prime \prime}\end{array}\right\}$

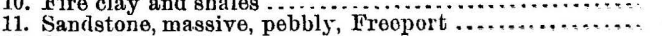

12. Coal, Upper Kittanning ...............................

13. Shains, dark .........................................

14. Coal, slate in center, Middle Kittanning ...............

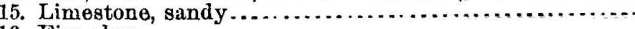

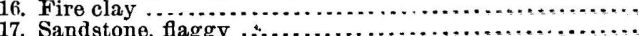

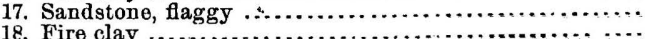

18. Fire clay

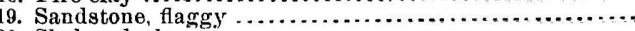

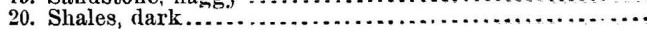

south of Kittau

Total. 
Section at Logansport, Pennsylvania.-The last section gets its special significance when compared with another one, obtained 2 miles below, on the right bank of the Alleghany River, and opposite the town of Logansport. The section there (Fig. 65) gives the following structure:

Logansport, Armstrong County, Pennsylvania.

[See map, G i.]

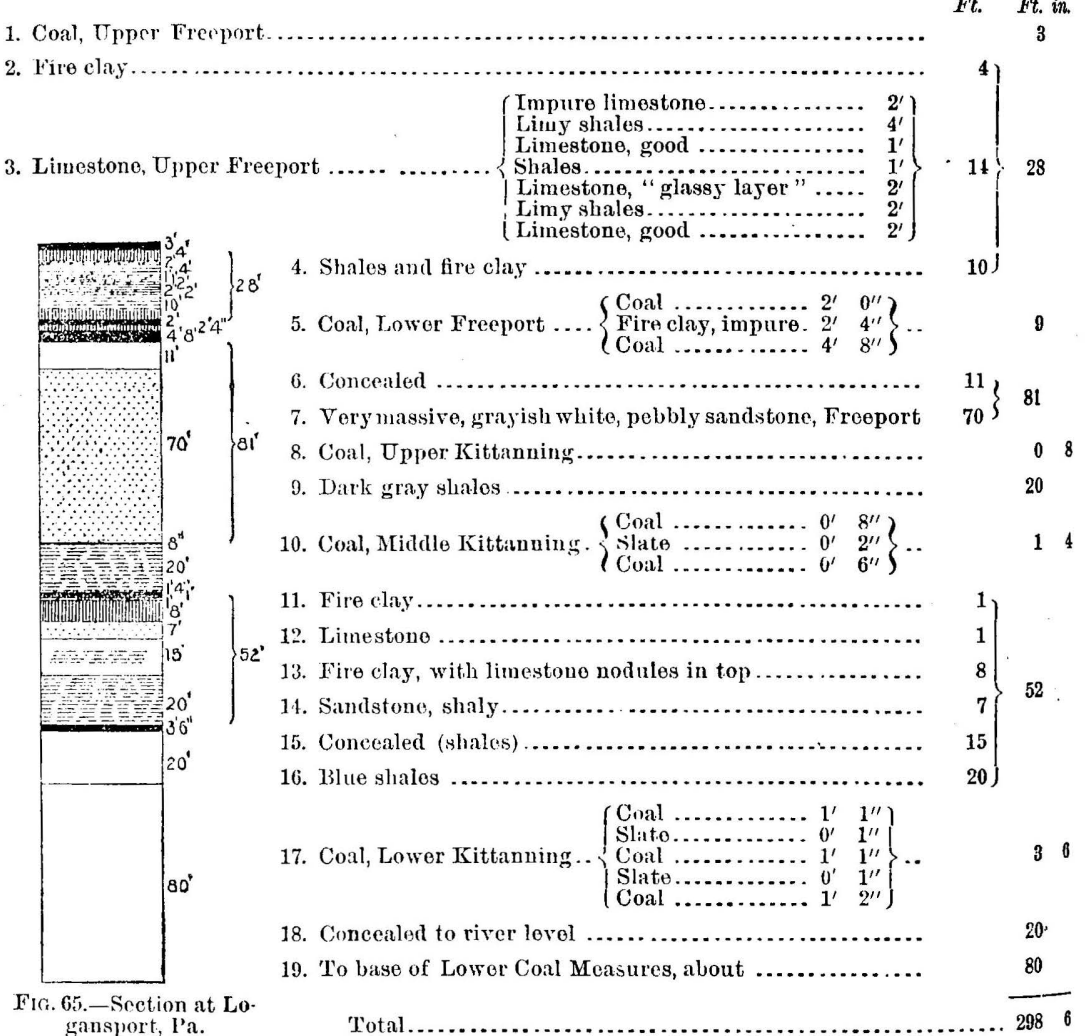

Here we find a ferruginous limestone making its appearance under what the section shows to be the Middle Kittanning coal, and it is pos. sible that this same bed may have occasionally been identified with the Johnstown Cement limestone in this portion of Pennsylvania, which would be erroneous, since that bed belongs under the little coal, No. 8 of the section, while the Johnstorn Cement bed, as correlated by Messrs. Platt and others, comes just under the Upper Kittanning coal.

The section also exhibits the great variations that may take place in the thickness of the intervals between important coal beds, that between the two Freeports being here reduced to only 28 feet. 
Section at Freeport, Pennsylvania.-Freeport, on the Alleghany River, at the southern point of Armstrong County and 7 miles southwest of Logansport, is a classic locality for the upper portion of the Lower Coal Measures, and the following section (Fig. 66), taken there. is given for the purpose of illustrating the relations of the Upper and Lower Freeport coais at this typical locality:

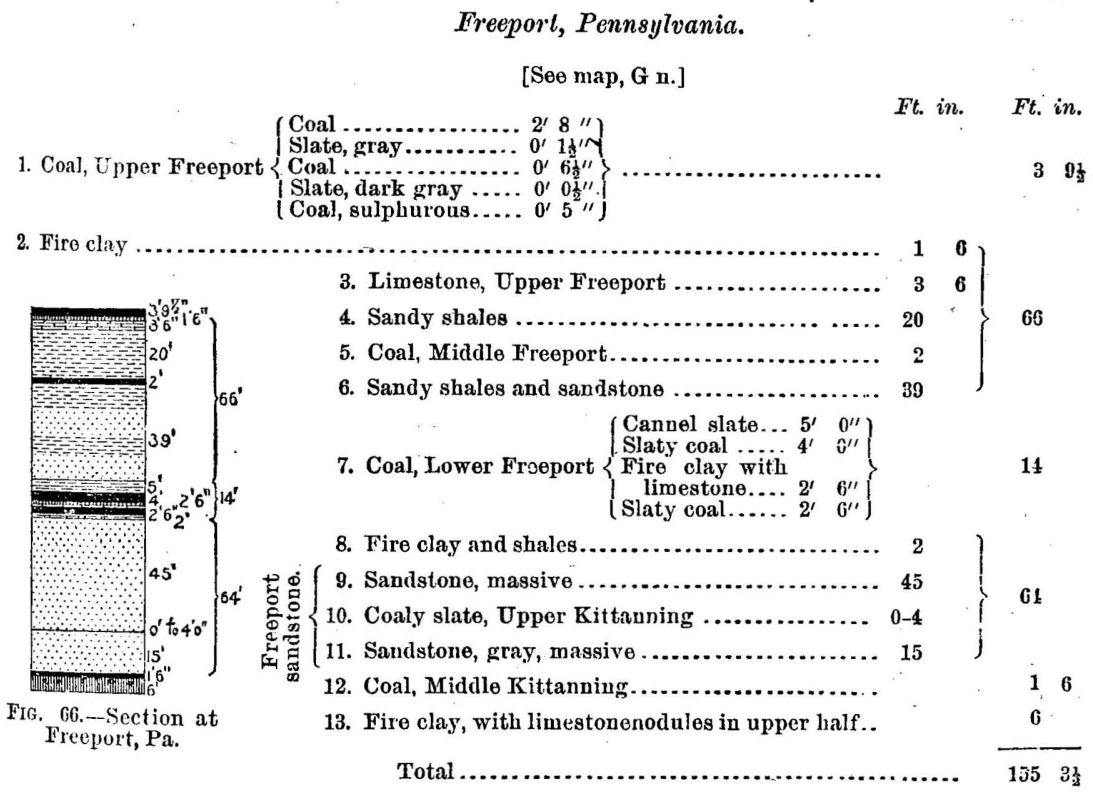

This section shows that there is a third Freeport coal, coming nearly midway between the upper and lower ones, at this, their typical locality, a fact that has been frequently overlooked by geologists, and that has led to error in identifications. This Middle Freeport coal, as I have termed it, is not persistent; but the fact that there is such a bed in the series occasionally should lead to careful scrutiny of this portion of the column of rocks before positive identification of the Lower Freeport coal.

This latter bed, No. 7, also has elements of possible confusion in its structure here at its type locality, since, as may be seen from the section, it is a double bed, made so by $2 \frac{1}{2}$ feet of fire clay, in which a nodular limestone occurs. It is possible that these parting rocks may expand to several feet in some regions, and thus give two Lower Freeport coals, as indeed they are known to do.

I have included No. 11 as a part of the Freeport sandstone, since at one locality the coal bed No. 10 thins out entirely and lets Nos. 9 and 11 unite into one solid sandstone; but it is possible that No. 9 alone should be included under the name Freeport sandstone, as originally intended by Rogers. 
Section near mouth of Beaver River, Pennsylvania.-In the region

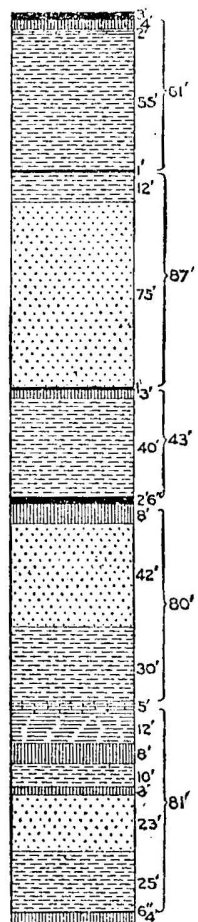

Fif. 67.-.Section near mouth of Beaver liver, I'at. about the mouth of the Beaver River, the Lower Cod Measures thicken up to a considerable extent, through the local expansion of some members, as shown by the following (Fig. 67) section of the structure there:

Ncar mouth of Beaver River, Beaver County, Pennsylvania.

[See map, G k.]

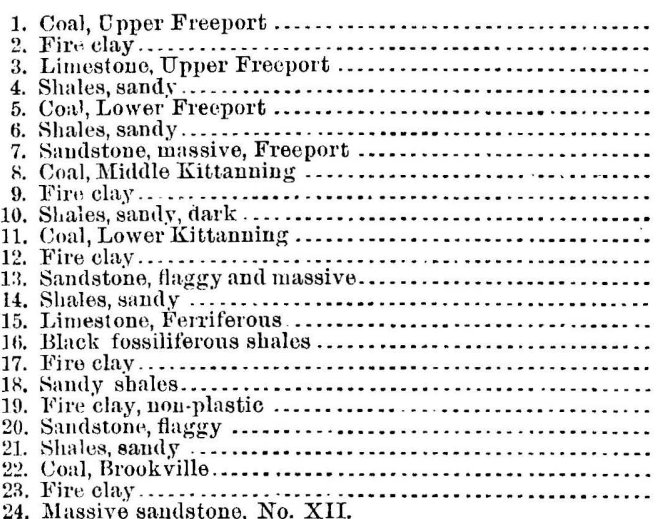

Ft. Ft. in

$\left.\begin{array}{r}4 \\ 55\end{array}\right\} 6$

1

$72\} \quad 87$

1

$\left.\begin{array}{r}3 \\ 40\end{array}\right\} \quad 43$

$8) 2$

40380

(1)

12
8
10

$10\} 8$

23

25

Total

369

Section at Sewickley, Pennsylvania.-At Sewickley, Alleghany County, Peinnsylvania, a test hole for coal was bored by Mr. Cochran Fleming, through whose courtesy the writer had the opportunity of measuring the carefully preserved cores trom the diamond drill, which gave this

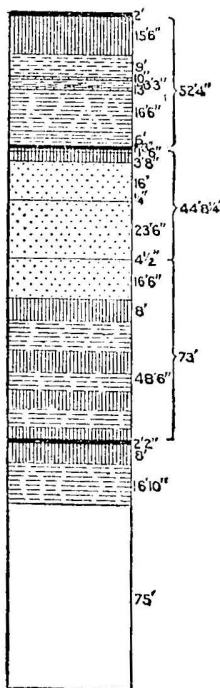

Fif. 68--Section at Sestructure (Fig. 68) for the rocks of the Lower Coal Measures there :

\section{Scwickley, Alleghany County, Pennsylvania.}

[Seo map, H l.]

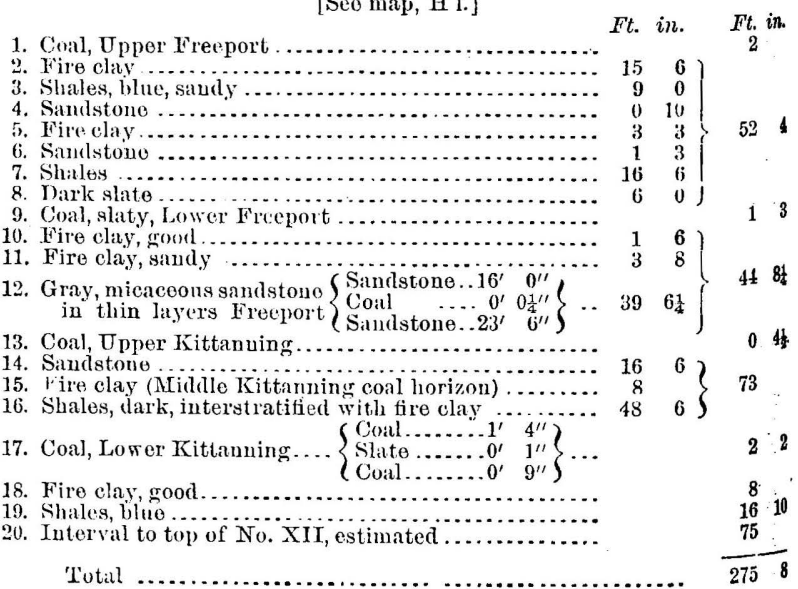


Section at Washington, Pennsylvania.-At Washington, Pennšlvania, the top of this series is 1,000 feet below the surface, and Prof. Linton,

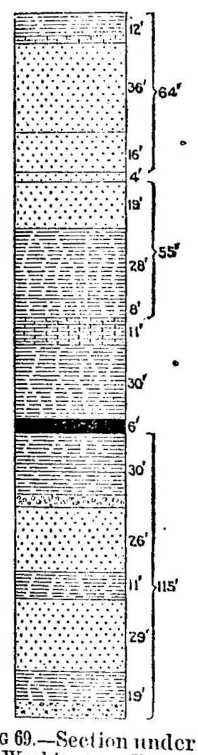
of Washington and Jefferson College, gives the following (Fig. 69) as the structure of its rocks according to the record of the Thayer oil well, the drillings from which he very carefully studied (Geological Survey of Penusylvania, 1886, pp. 764, 765):

Under Washinğton, Pennsylvania.

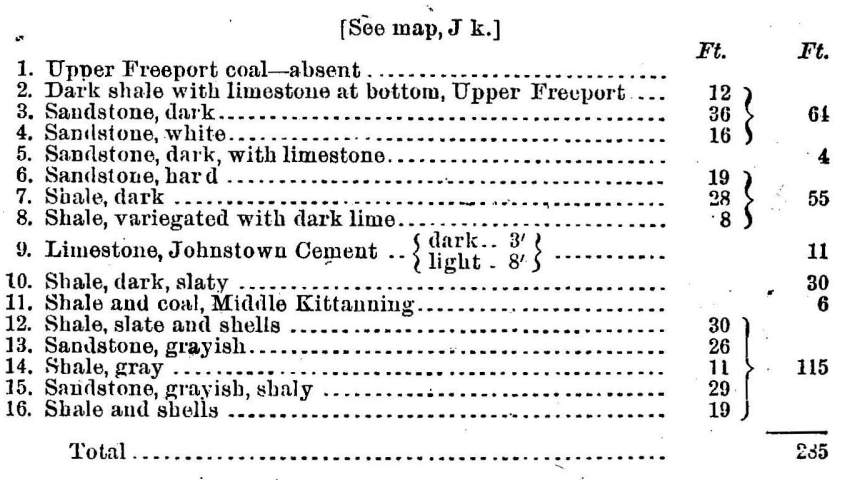

Washington, $P$ a.

Here there is only one coal present in the series and it would appear to be the Middle Kittanning.

Section near Carpenter's Stätion, Westmoreland County, Pennsylvania.Near the main line of the Pennsylvania Railroad, in the vicinity of Car-
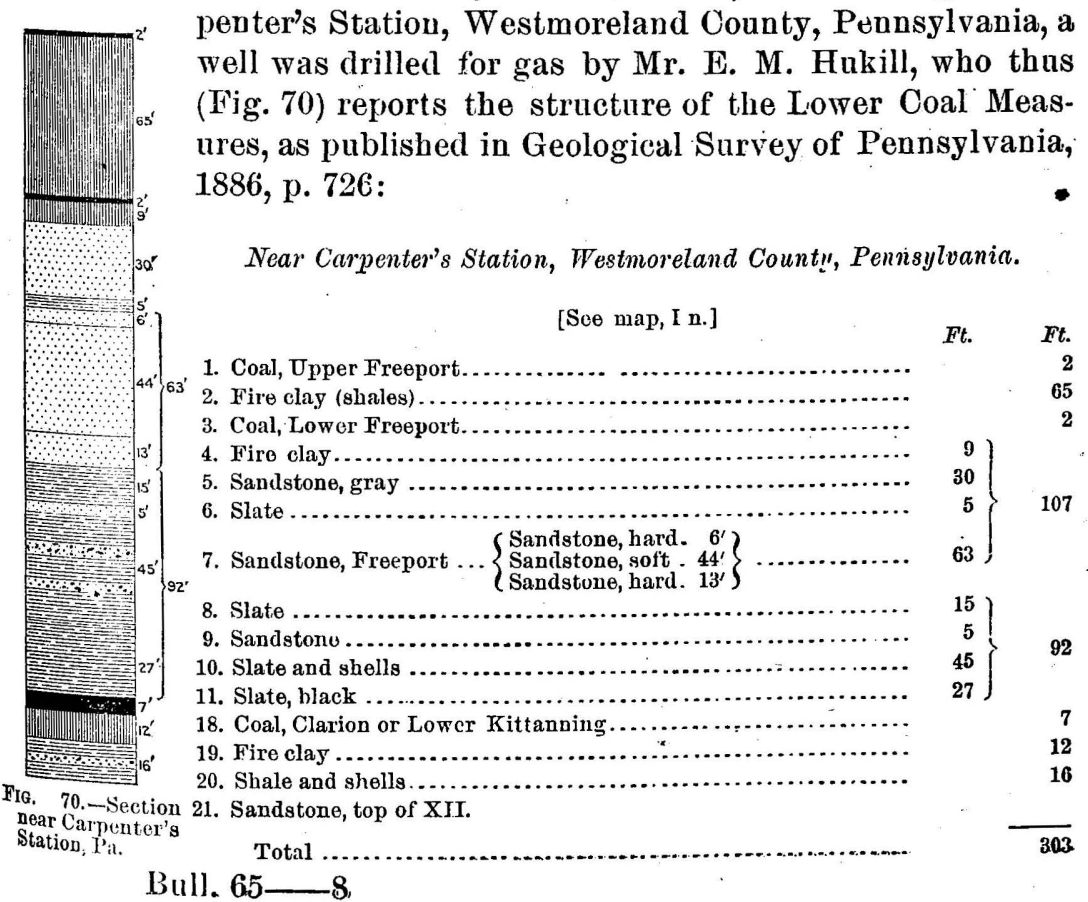

Bull. 65-8, 
Section under Mitiraysville, Pennsylvania.-At Murraysville, West. moreland County, Pennsylvania, in the celebrated natural gas region, the top of the Lower Coal Measures lies 60 to 75 feet below the surface,

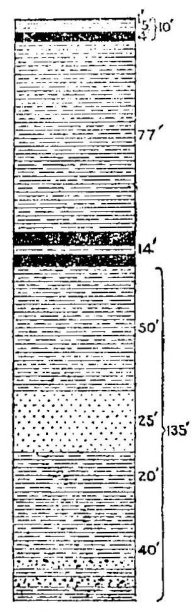

FIG. 71.-siection umiler Murrays. ville, Pa. and the structure of the series is thus given (Fig. 71) by Mr. Donbleday, from the records of a gas well on the Remaley farm, Geological Survey of Pennsylvania 1886, p. 721 :

Under Murraysille, Westmoreland County, Pennsylvania.

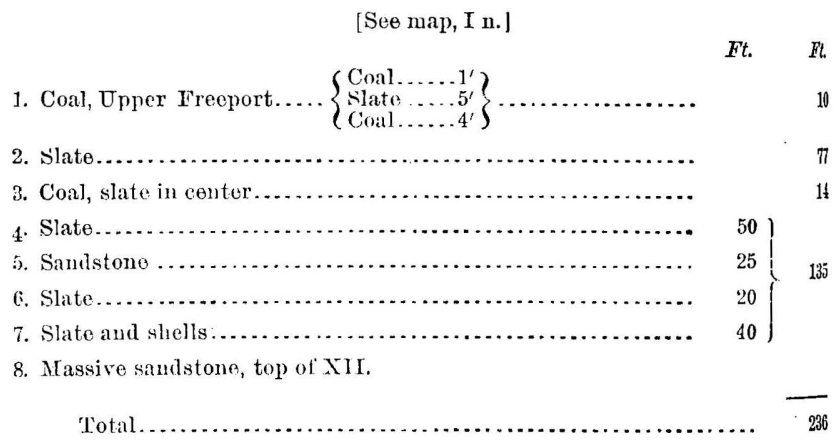

Section on Beaver Run, Westmoreland County, Pennsylvania.-About 9 miles northeast of Murraysville a well was drilled on Beaver Run, beginning ouly 4 feet below the level of the Upper Freeport coal. The record (Fig. 72) of this well, as given by Mr. J. A. Mehaffey, shows the following structure there (Pennsylvania Geological Survey, 1.886, p. 728$)$ :

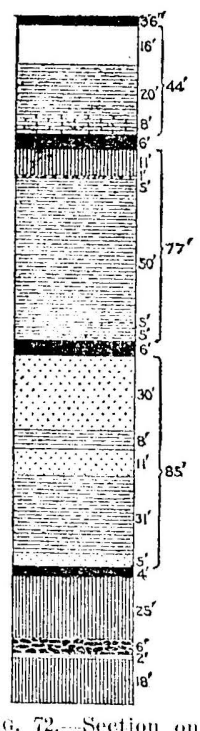

biver 12 ind lon on

Beaver Run, Hestmoreland County, Pennsylvania.

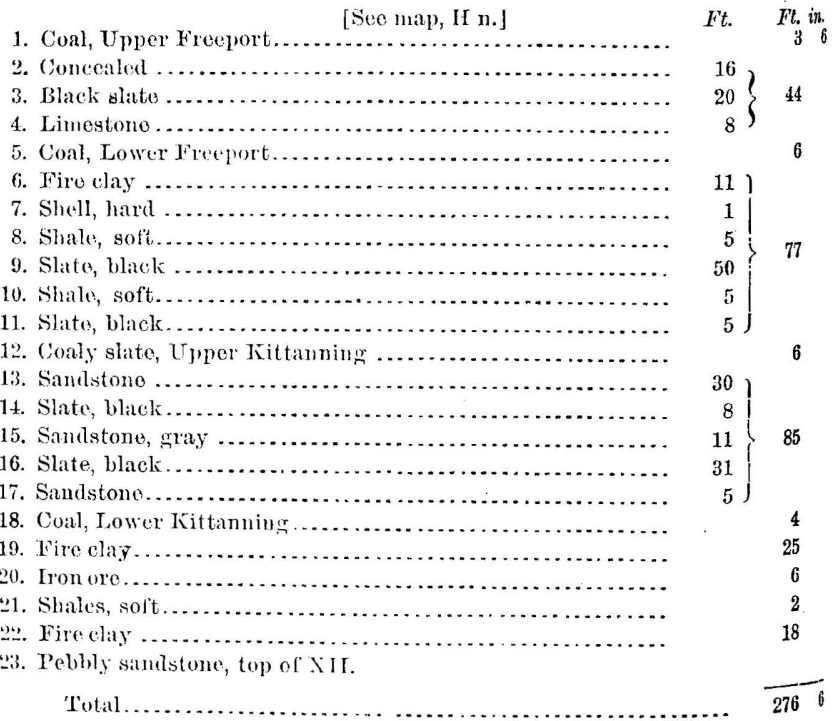


Section near Richmond, Pennsylvania.-In the northern portion of Indiana County, Penusylvania, in the vicinity of Richmond village,

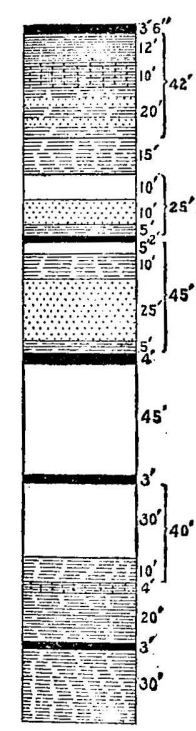

Fig. 73.-.Section near Richmond, $\mathrm{Pa}$.

the Lower Coal Measures exhibit the following structure(Fig. 73) according to Mr. Wm. G. Platt, $\mathrm{B}^{4}$, p. 266 : Near Richmond, Indiana County, Pennsylvania.

[See map, F p.] [See map, F p.] Ft.

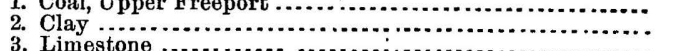

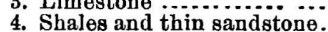

5. Coal, Lower Freeport $\{$ Coal.... thin 5. Coal, Lower Freeport.... $\left\{\begin{array}{l}\text { Shales. 15 } 15^{\prime} \\ \text { Coal... thin }\end{array}\right\} \ldots . . . . . . . .$. Ft. Ft. in.

6. Concealed.

$\left.\begin{array}{l}12 \\ 10\end{array}\right\} 42$

8. Clay slate.

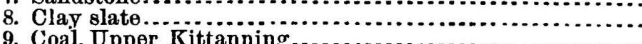

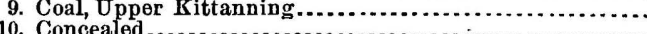

11. Shales

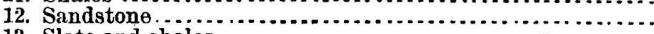

13. Slate and shales

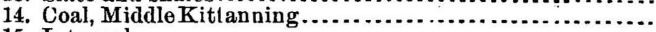

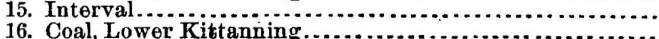

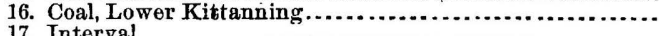

17. Interval

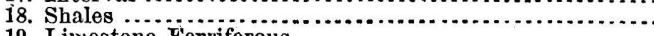

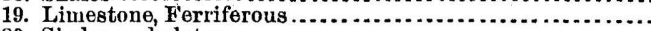

20. Shales and slates.......................................

21. Coal, Clarion .......................................

22. Shales .

23. Sandstone, massive, top of XIIr.

Total .

Section neair Lockport and Bolivar, Indiana County, Pennsylvania.-In the vicinity of Bolivar and Lockport just east of the Chestnut Ridge anticlinal, Mr. Wm. G. Platt finds the following succession (Fig. 74) for these measures as given in $\mathrm{H}^{4}$, p. 65:

Near Lockport and Bolivar, Indiana County, Pennsylvania.

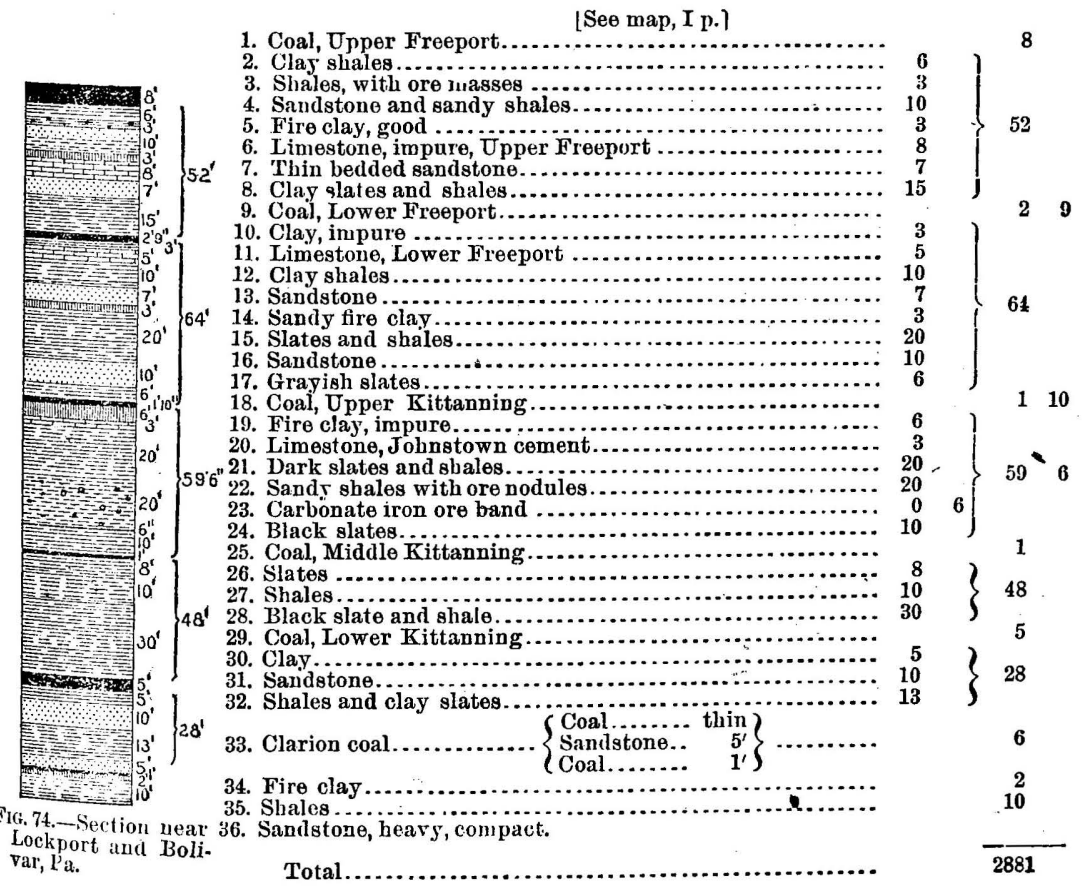


Section near Laughlinstown, Pennsylvania.-In the vicinity of Laugh. linstown, Westmoreland Connty, and 10 miles south from Bolivar, Dr. Jno. J. Stevenson (KKK, p. 135) reports the Lower Coal Measures with the following structure (Fig. 75):

Laurel Run, Ligonier Tounship, Westmoreland County, Pennsyl. vallia.

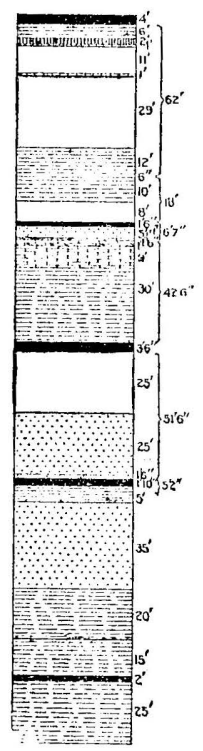

Fif. 75..-. Stection on Laturel Rinn, Ia.

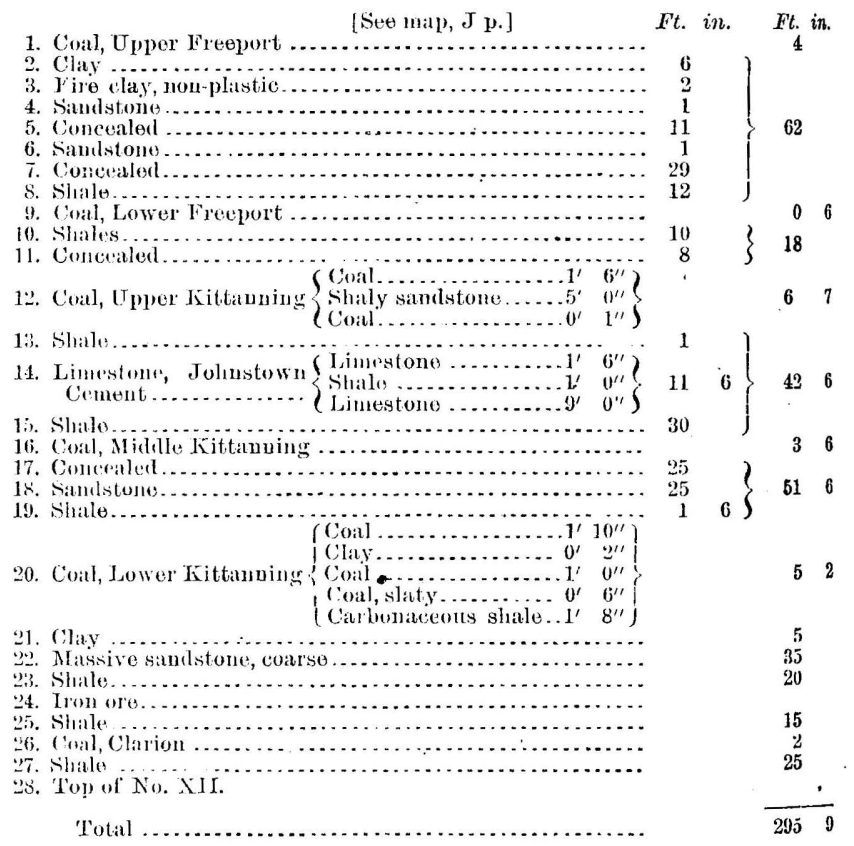

Total

Section on Cucumber Lun, Stewart Toncuship, Fayette Connty, Pennsyl-

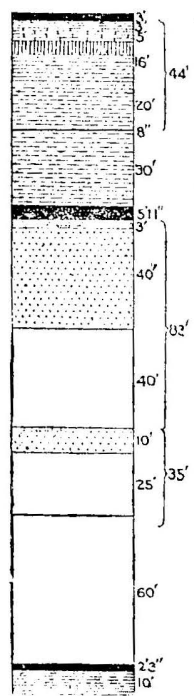

varia.-In this same basin (Ligonier) and on southwestward near the Youghiogheny River, in Fayette County, the Lower Coal Measures exhibit the following structure (Fig. 76) on Cucumber Run, as reported by Stevenson (KKK, 1. S3):

Cucumber Lun, Stewart Township, Fayette County, Pennsylvania.
1. Coal, Upper Freeport.
[See malp, K n.]
3. Liniestome, Freport

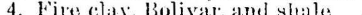

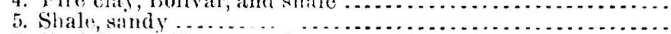

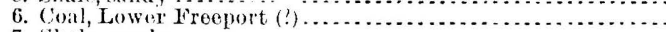
7. Shate, sindly

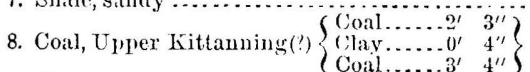
10. Siandstone, Freeport (?)

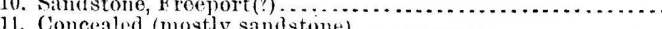
1.2. Coal, Midale Kittanning......................................

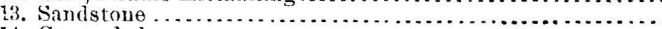
14. Concealerd

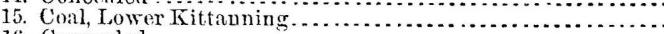
16. Concealed.
17. Go:l, Glarion or Brookville.
18. Shaie and clas

Frr. 76.-Seetion on 19. Samdstone, massive, top of XII.

C'unmber linn, lay. otte County, P'a.

'Tutal.

$$
\begin{aligned}
& \text { Ft. Ft. in. } \\
& \left.\begin{array}{r}
3 \\
5 \\
16
\end{array}\right\} \quad 44 \\
& 16 \\
& \begin{array}{ll}
0 & 8
\end{array} \\
& 30 \\
& 511 \\
& \begin{array}{r}
3 \\
40
\end{array} \quad 83 \\
& 40\} \\
& 10)^{b} \\
& 25\} \text { blossom } \\
& \text { b]ossom } \\
& 10 \\
& \text { - } \overline{273 \quad 10}
\end{aligned}
$$


Section at Newburg, West Virginia.-Newburg, on the Baltimore and Ohio Railroad, in Preston County, West Virginia, is situated at the center of the same coal basin as Bolivar, Ligonier, etc., and there a deep shaft reveals the following structure (Fig. 77) for the Lower Coal Measures :

Shaft at Newburg, Preston County, West Virginia.

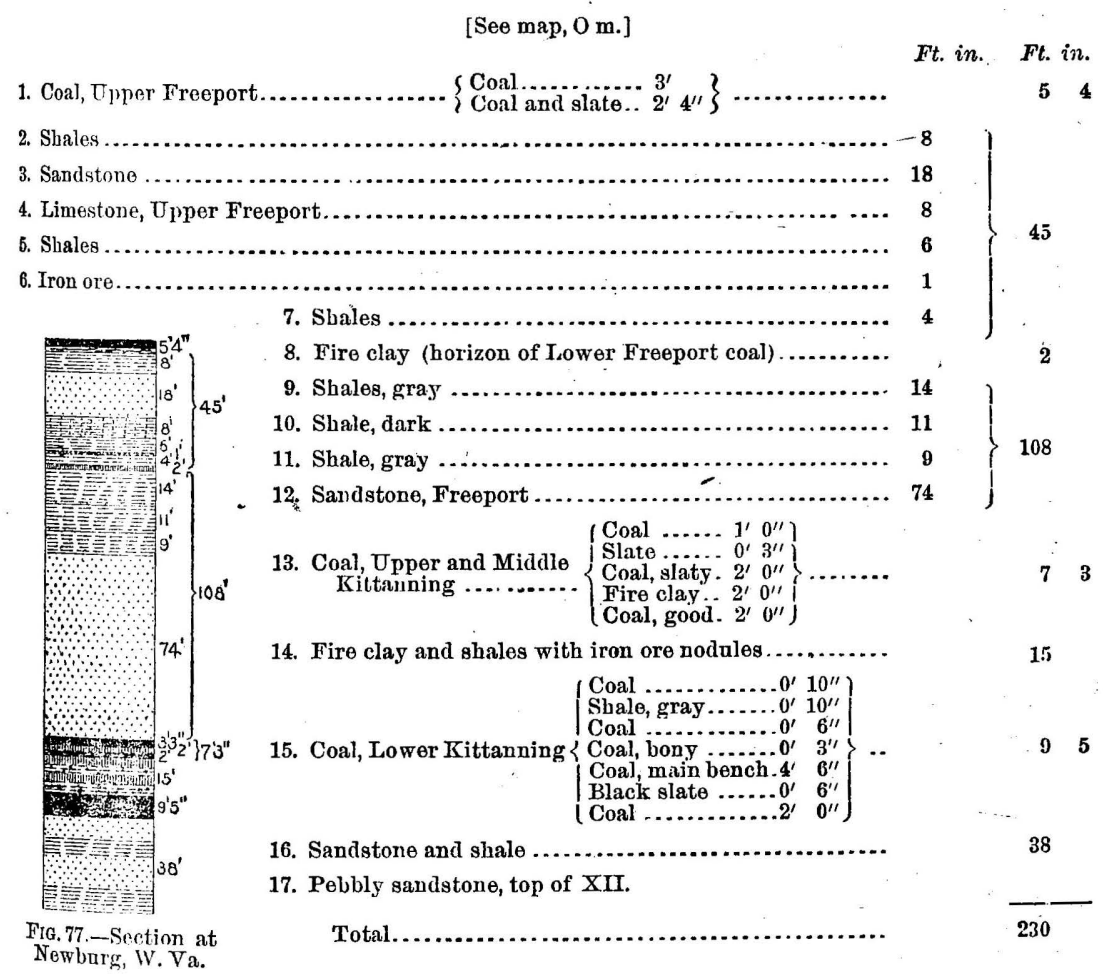

Here the Upper Freeport coal lies 150 fest below drainage and 700 feet below the tops of the immediate hills.

No. 13 appears to represent both the Upper and Middle Kittanning coal beds, which are brought practically together, and also very close to the Lower Kittanning bed by the thinning away of intervening rocks.

The interval under the Lower Kittanning bed here is revealed by a dianond drill hole which was put down 150 feet below the latter stratum.

The Lower Freeport coal is not present, but its borizon is clearly indicated by the bed of fire clay, No. 8 , at 45 feet nuder the Upper Freeport coal.

The Freeport sandstone, No. 12, has a large derelopment, and where it comes to the surface, 4 miles above Newburg, is nearly 100 feet thick. 
Section at Johnstown, Pennsyliania.-Johnstown, Pennsylvania, lies just east of the Laurel Hill anticline, and the Lower Coal Measures have there been splendidly exposed through the mining operations of the Cambria Iron Company. The following section (Fig. 78) of the rocks in that region is given by the chief engineer of the Cambria Company, Mr. John Fulton $\left(\mathrm{H}^{3}\right.$, pp. 308, 309):

Vicinity of Johnstown, Cambria County, Pennsylvania.

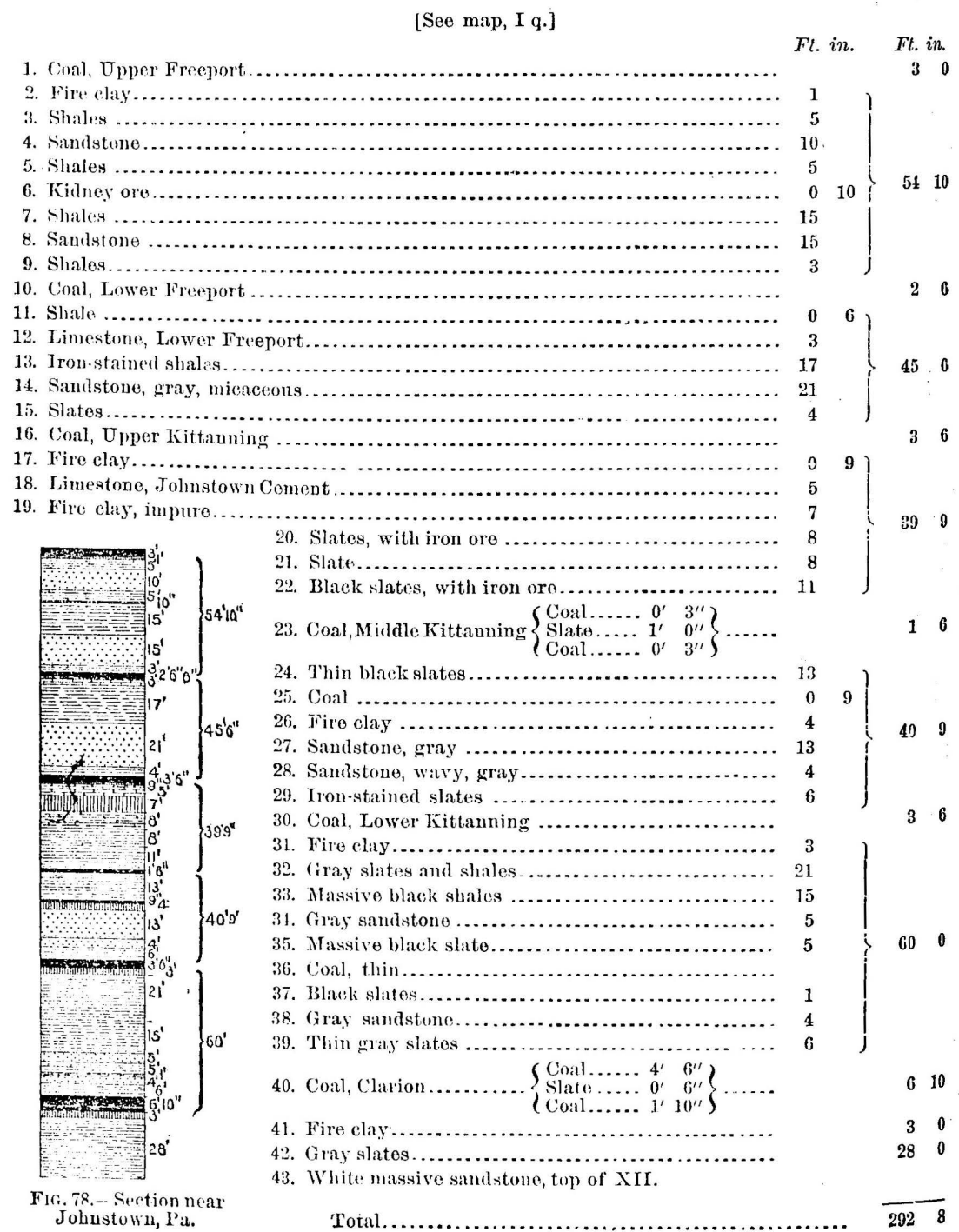


Section at Conemaugh, near Johnstown, Pennsylvania.-The writer compiled a section of the Lower Coal Measures at Qonemaugh and else-

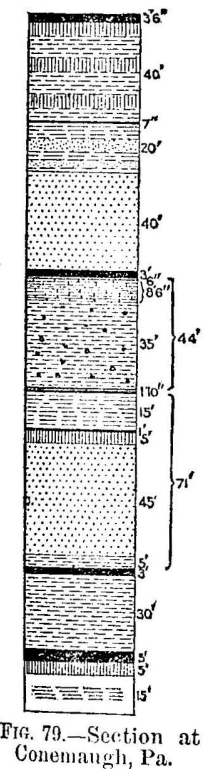
where in the vicinity of Johnstown, which differs only in minor details from that of Mr. Fulton. It reads as follows (Fig. 79):

Neav Johnstown, Pennsylvania.

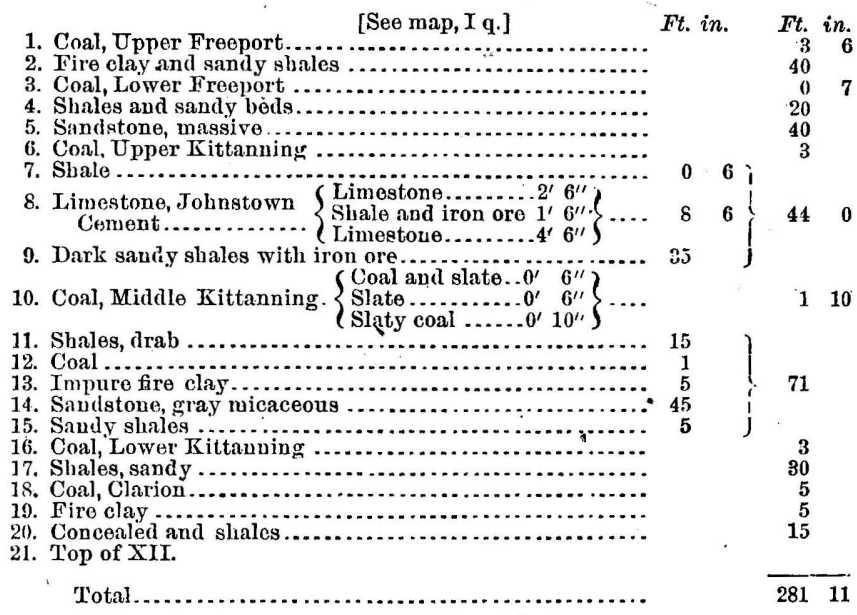

Section in Jackson Township, Cambria County, Pennsylvania.-In Jackson Township, Cambria County, 8 miles northeast of Johnstown, a well was once drilled for oil, and I obtained from the con. tractor the following record (Fig. 80) of the strata representing the Lower Coal Measures. It is chiefly important as giving the total thickness of the series in a vertical measurement:

\section{Jackson Township, Cambria County, Pennsylvania.}

[See map, I q.]

1. Coal, Upper Freoport.......................................... 38

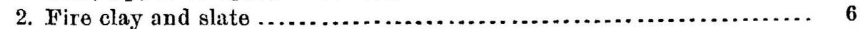

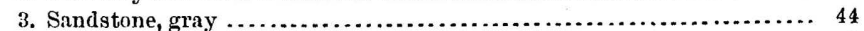

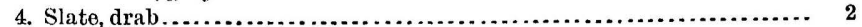

5. Coal, Lower Freeport............................................ 4

6. Firo clay and limestono ....................................... 6

7. "Soapstone" (shale) .......................................... 56

8. Sandstone, gray .................................................. 36

9. Coal and slate, Lower Kittanning ............................. 6

${ }_{10}$. Sandstone, gray................................................ 48

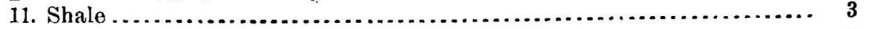

12. Coal, Clarion .................................................... 6

13. Fire clay ......................................................... $3{ }^{6}$

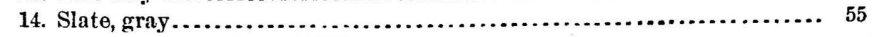

FIG. 80.-Section 15. Hard sandstone, top of XIL.

in Jackson Townslip, Cambria

Total 
Section on Ben's Creel, Cambria Cunty, Pennsylvania.-Near the eastern border of Cambria County, along the waters of Ben's Creek, in Washington Township, the following section (Fig. 81 ) is reported by Mr. Frauklin Platt $\left(\mathrm{H}^{2}\right.$, p. 48$)$ :

Ben's Creek, Cambria County, Pennsylvania.

[See map, I q.]
1. Coal, Upner Freeport
2. Fire clay
3. Back slates and shales
4. Limestone, Upper Freeport ............................................

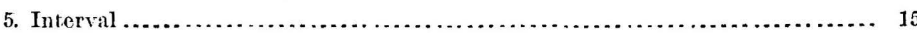
6. Sandstone................................................... 19

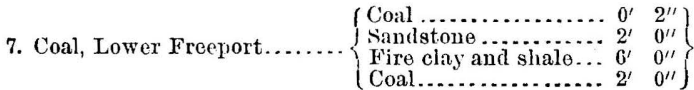
8. Fire clay
9. Limestone, Lower Freeport ...
10. Shales, iron-bearing
11. Coal, smut
12. Fire clay, shales, with ore balls.
13. Coal, smut
14. Fire clay
15. Slates and shales
16. Black slates

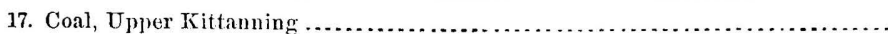

Ft. in. Ft. in.

18. Fire clay

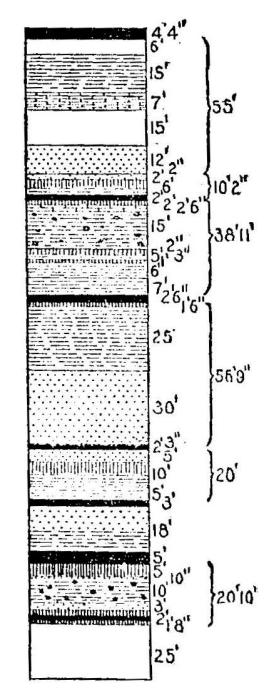

Fir. 81.-Section on Ben's Creek, Cambria County,
19. Drab shales.

20. Sandstove, fine grained

21. Black slate

22. Coal, slaty, Mirliłe Kittanning

23. Fire clay

24. Sandstone

25. Fire clay, shale.

26. Black slate.

27. Coal, Lower Kittonning

28. Samistone and shale.

29. Coal, Clarion

30. Hire diay

31. Sandstone.

32. Dove-colored shale, with ore

33. Sandstone.

34. Fire clay, shale

35. Coal, Brookvillo

36. Fire clay

37. Conceated

38. Toy of XII

Total 
Section near Stoyestown, Pennsylvania.-In the vicinity of Stoyestown, on Stony Creek, Somerset County, Pennsylvania, near the center

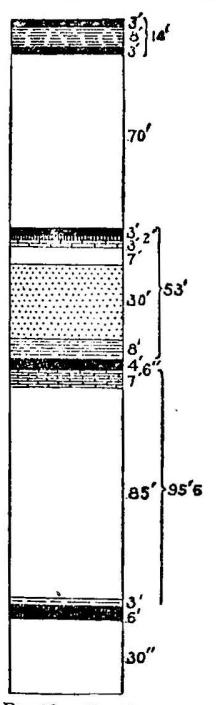

FJg.82.-Section near Stosestown, Pa. of the basin between the Viaduct and Negro Monntain anticlines, the series exhibits the following structure (Fig. 82) according to Mr. Franklin Platt $\left(\mathrm{H}^{3}\right.$, p. 129):

Stoyestoun, Somerset County, Pennsylvania.

[See map, J q.]

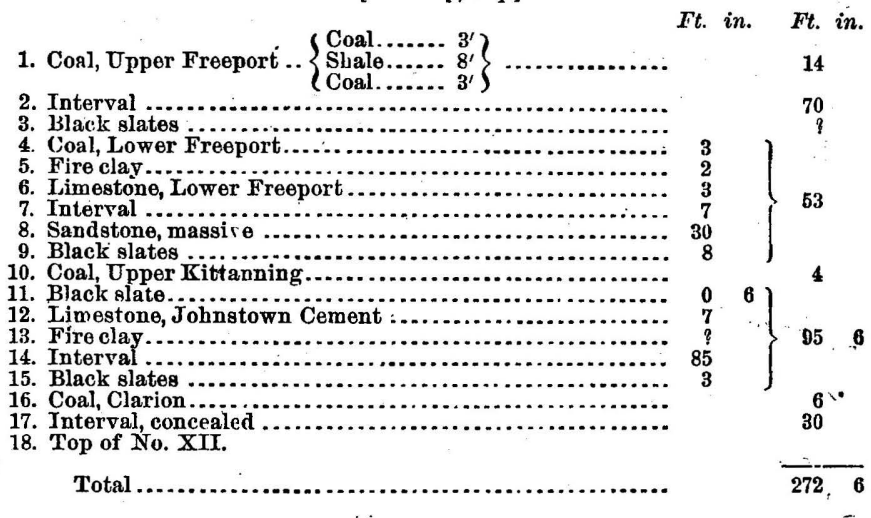

Section at Pinkerton Point, Pennsylvania.-On the Castleman River at Pinkerton Point, in the southern portion of Somerset County, a very complete section of the Lower Coal Measures was obtained by Mr. Franklin Platt along the Baltimore and Ohio Railroad, near Shoo Fly Tunnel, and is reported as follows (Fig. 83) $\left(\mathrm{H}^{3}\right.$, pp. 202, 203) :

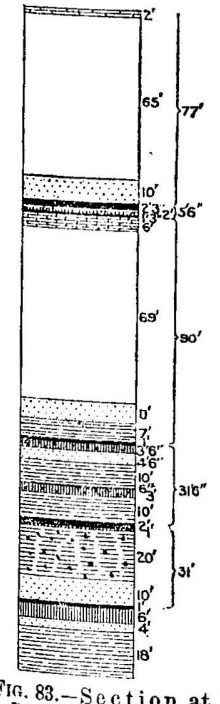

Pinkerton Point, Somerset County, Pennsylvania.

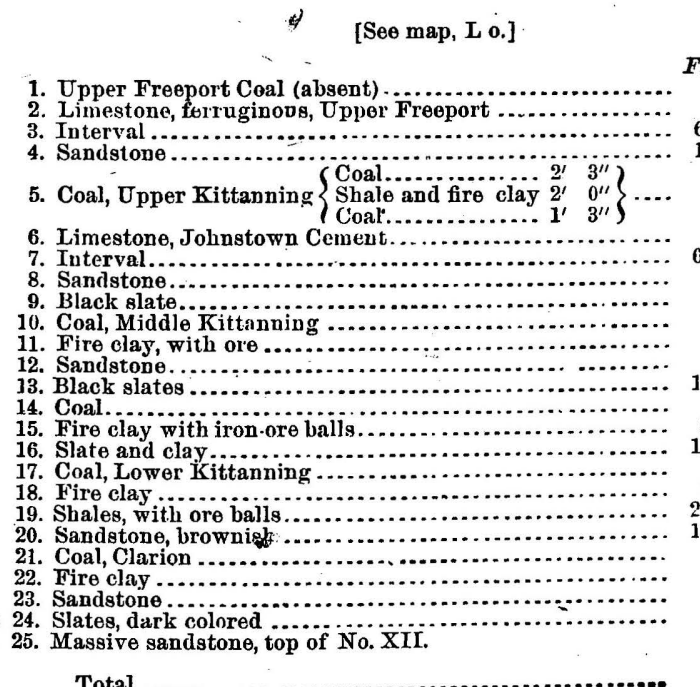

Ft. in. Ft. in.

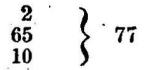

$\{77$

Pinkerton Petion at

Pinkerton P o in t,
Somerset County,

Total 
Section near Cresson, Pennsylvania.-An oil boring near Cresson, on the summit of the Alleghany Mountains, gives the following measurements (Fig. 84 ) for the Lower Coal Measures $\left(\mathrm{H}^{2}\right.$ page

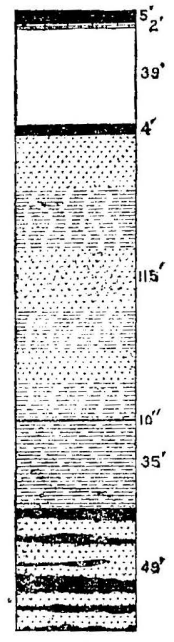

Fig. 8t.-Section near Cresson, $\mathrm{Pa}$. $30)$ :

Boring at Cresson, Cambria County, Pennsylvania.

[See map, H r.]

1. Coal, Upper Freeport ....

2. Limestone, Upper Freeport ................................... 2

3. Mixed drilling ............................................ 39

4. Coal, Lower Freeport ....................................... 4

5. Shelly "soapstone" (sandstones and shales) .................... 115

6. Cannel coal ................................................ 010

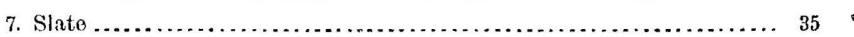

8. Coal, mixed with sandstone ................................. 49

9. Hard sandstone (No. XII).

Total ...............................

Section at Bennington, Pennsylvania.-Just over the crest of the Alleghany Mountains, at Bennington, Blair County, the following section (Fig. 85) of this series has been carefully worked out by Mr. John Fulton and

Franklin Platt $\left.\left(\mathrm{H}^{2}, \mathrm{pl}\right) .3,4\right)$ :

Bennington, Blaiv County, Pennsylvania.

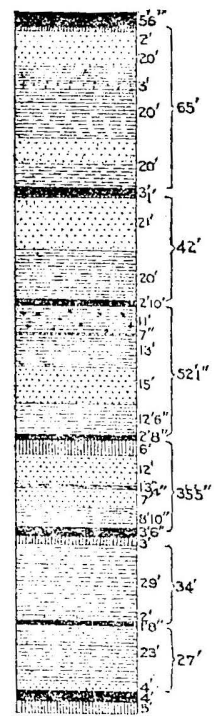

Fic. 85.--Section at Bounington, $\mathrm{Pa}$.
[Seo map, If r.]

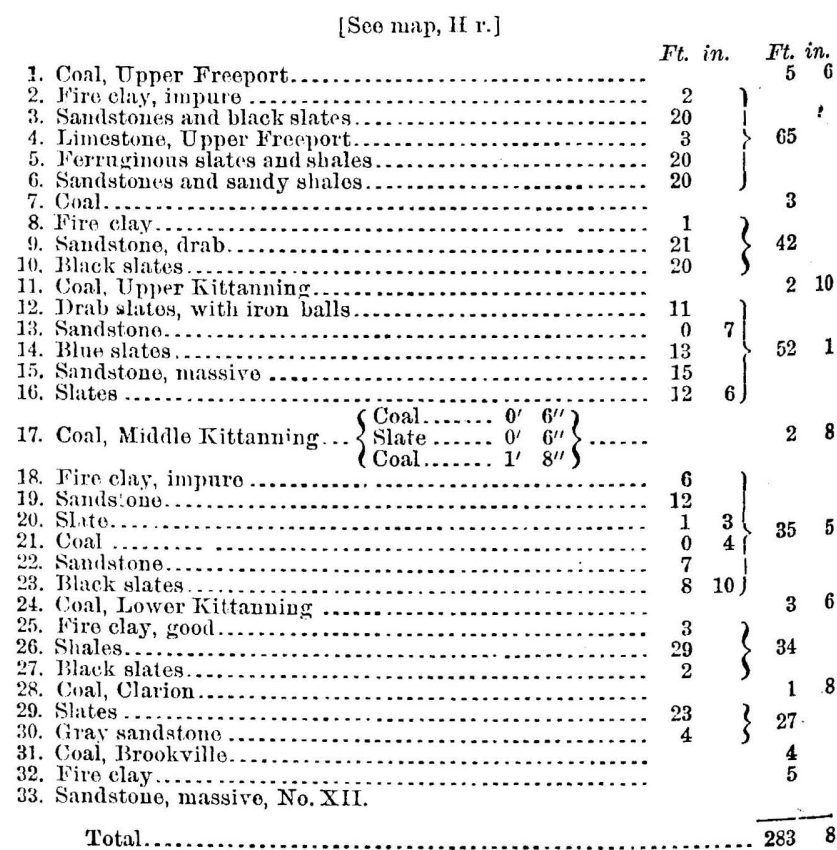


Section at Clearfield, P.ennsylvania.-At the town of Cleartield, Clearfield County, Penusylvania, the following section (Fig. 86) was made by the writer:

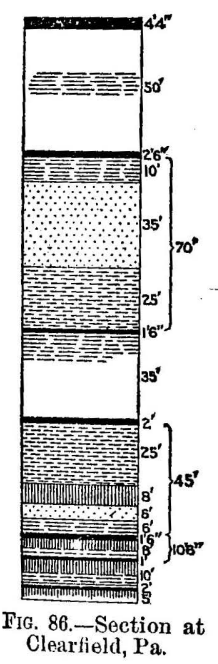

\section{Clearfield, Pennsylvania.}

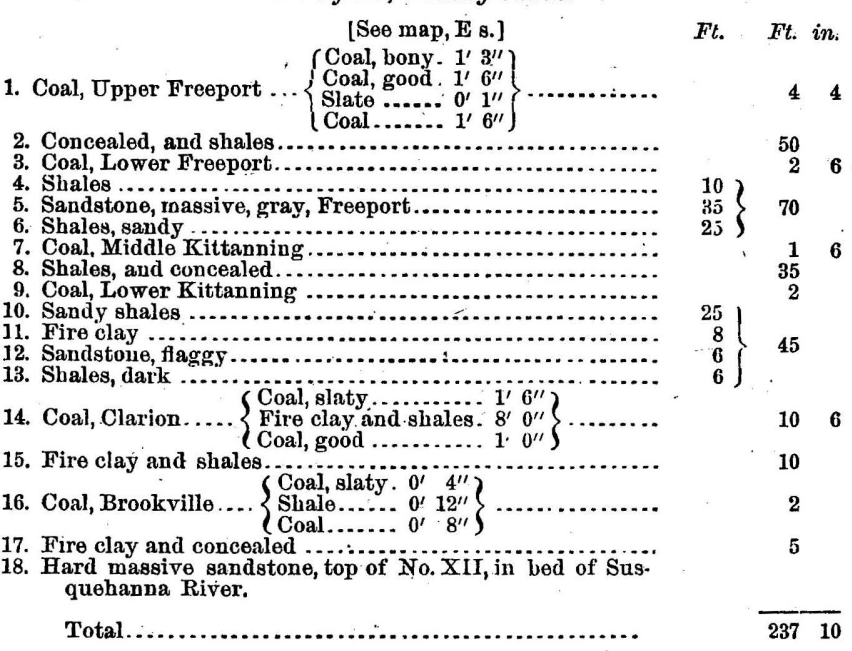

Section near Morrisdale, Pennsylvania.-Near Morrisdale, Clearfield County, the following section (Fig. 87) is reported by Mr. H. Martyn Chance $\left(\mathrm{H}^{7}\right.$, p. 61$)$ :

Near Morrisdale, Clearfield County, Pennsylvania.

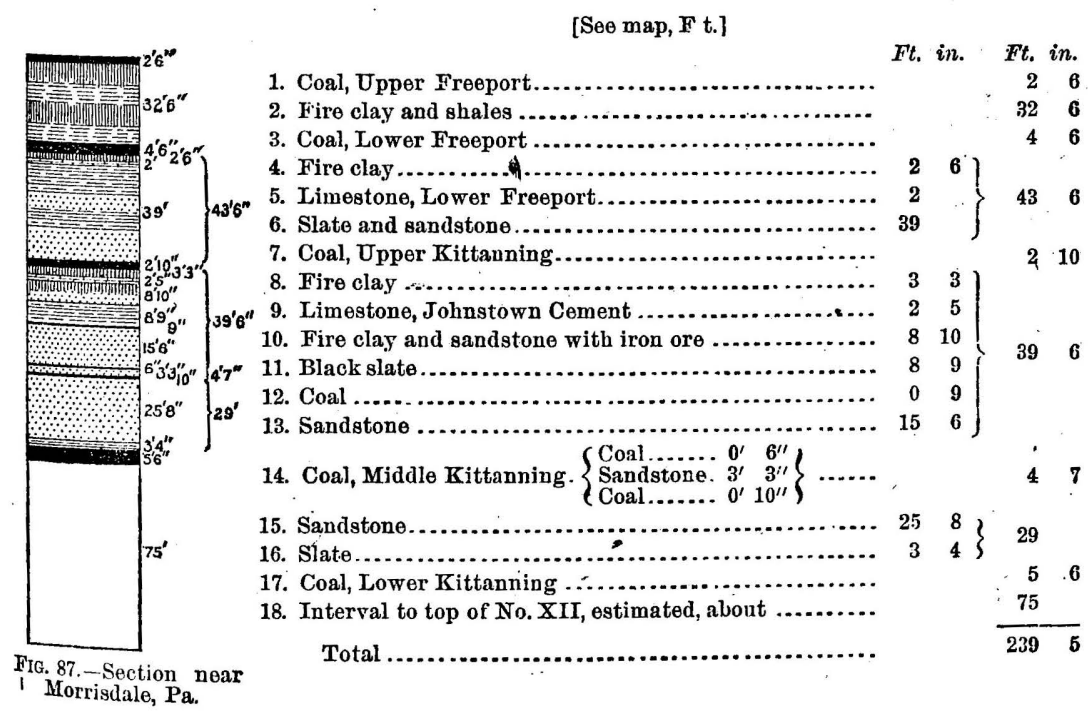


Section at Sterling Mines, near Houtzdale, Pennsylvania.-At tho Sterling mines of R. H. Powell's Sons \& Co., Clearfield County, a diamond-drill boring was sunk through the Lower Coal Measures, beginning 10 feet below the level of the main coal mined in that region. I copied the record of this bore hole from the office of the company, and it, combined with the surface exposures, gives the following succession (Fig. 88):

Boring at Sterling Mines, near Houtzdale, Clearfield County, Pennsylvania.

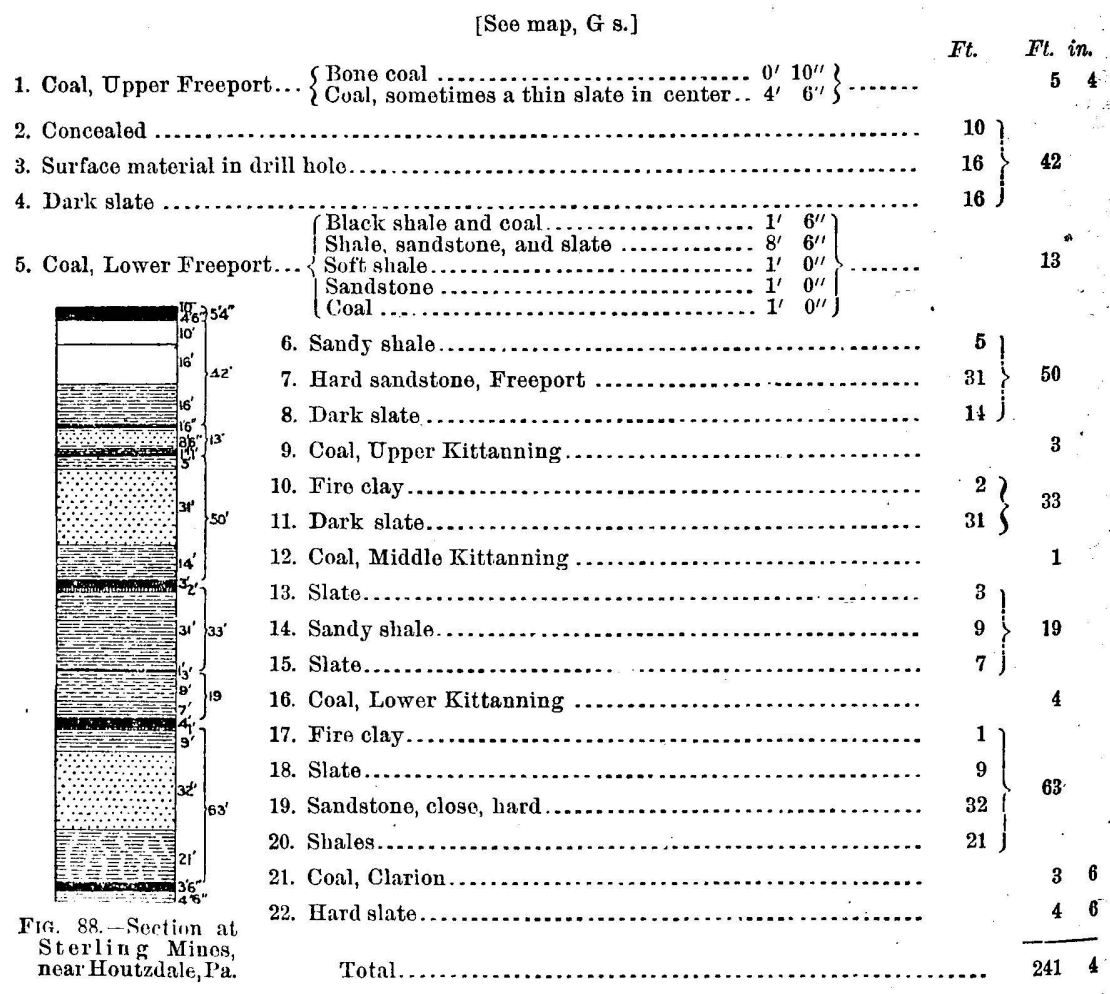

The coal at the top of this last section has been identified as the Lower Freeport bed, throughout the Clearfield region, by Messrs. Platt, Chance, and other Penusylvania geologists; but it seems to me that this section, taken in connection with the one at Clearfield (Fig. 86), tends to prove that the coal in question is the Upper Freeport. This interpretation is further confirmed by the presence of the Lower Mahoning sandstone on above No. 1, and a thin coal, the Mahoning bed, at 60 to 80 feet above the latter, while crowning the hills is the Upper Mahoning sandstone, whose top is 100 feet above No. 1 . Then, too, the structure of the coal itself is the same as the Upper Freeport, a few miles distant, where it is mined along the Pennsylvania Railroad, in the edge of Blair County. 
Section at Shoup's Run, Broad Top Basin, Huntingdon County, Pennsylvania.-In the Broad Top coal basin, Shoup's Run, Huntiugdon County, Pennsylvania, the Lower Coal Measures exhibit

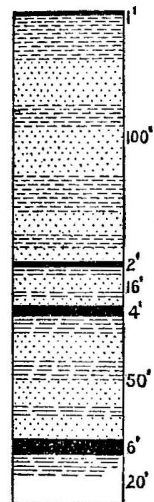
the following structure (Fig. 89), as given by the writer in $\mathrm{T}^{3}$, Geological Survey of Pennsylvania, page 46 :

Shoup's Run, Broad Top Basin, Huntingdon County, Pennsylvania.

[See map, $\mathbf{J}$ t.]

1. Coal, Upper Freeport

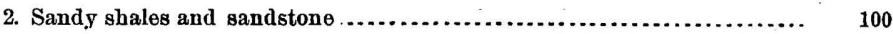

3. Coal, Upper Kittanning.........................................

4. Shales and sandstone................................................ 16

5. Coal, Middle Kittanning ......................................... 4

6. Shales and shaly sanḋstone...................................... 50

7. Coal, Lower Kittanning......................................... 6

FIG. 89....Section 8. Shales and concenled......................................... 20

at Shoup's Ruu, 9. Massive conglomerate.

Broad lop Ba-

County, Pa.

Total.

199

Section in East Broad Top Basin, Huntingdon County, Pennsylvania.In the East Broad Top region of Huntingdon County the structure is thus (Fig. 90) given by Mr. H. N. Sims (T33, p. 68):

East Broad Top Basin, Huntingdon County, Pennsylvania.

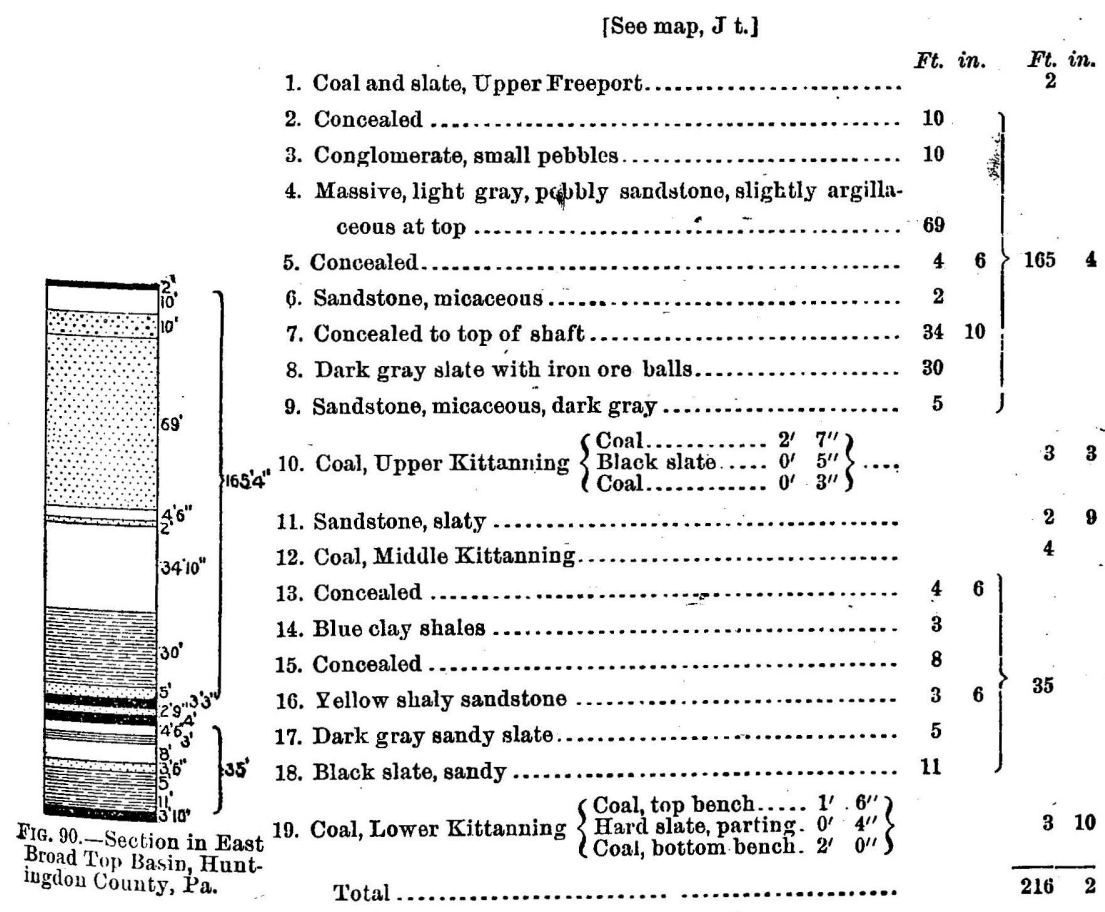


Section in Broad Top Basin, Bedford County, Pennsylvania.-In the Broad Top Basin of Bedford County, Pennsylvania, the structure is thus (Fig. 91) given by Stevenson $\left(\mathrm{T}^{3}, \mathrm{pp} .59\right.$ and 60$)$ :

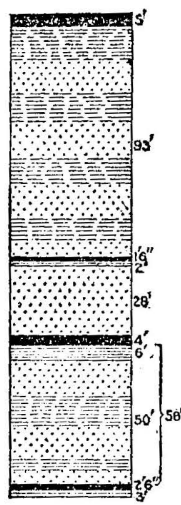

Fic. 91.-Section in Broad 'lop Basin,

Broad Top Basin, Bedford County, Pennsylvania.

[See map, J t.]

1. Coal, Upper Freeport.

2. Shales and sandstones

3. Coal, Upper Kittanning.

4. Cliay

5. Sandstone

6. Coal, Midlle Kittanning

7. Clay

8. Sandstone and shale.

9. Coal, Lower Kittanning

10. Clity

11. No. XII, conglomerate.

Total
Ft. Ft. in

5

93

16

2

28

4

$\left.{ }_{50}^{6}\right\} \quad 56$

26

Section at Piedmont, West Virginia.-In the vicinity of Westernport, Maryland, where the North Potomac cuts across the Cumberland or George's Creek coal basin, the Lower Coal Measures exhibit the following succession (Fig. 92):

Piedmont, Mineral County, Test Virginia.

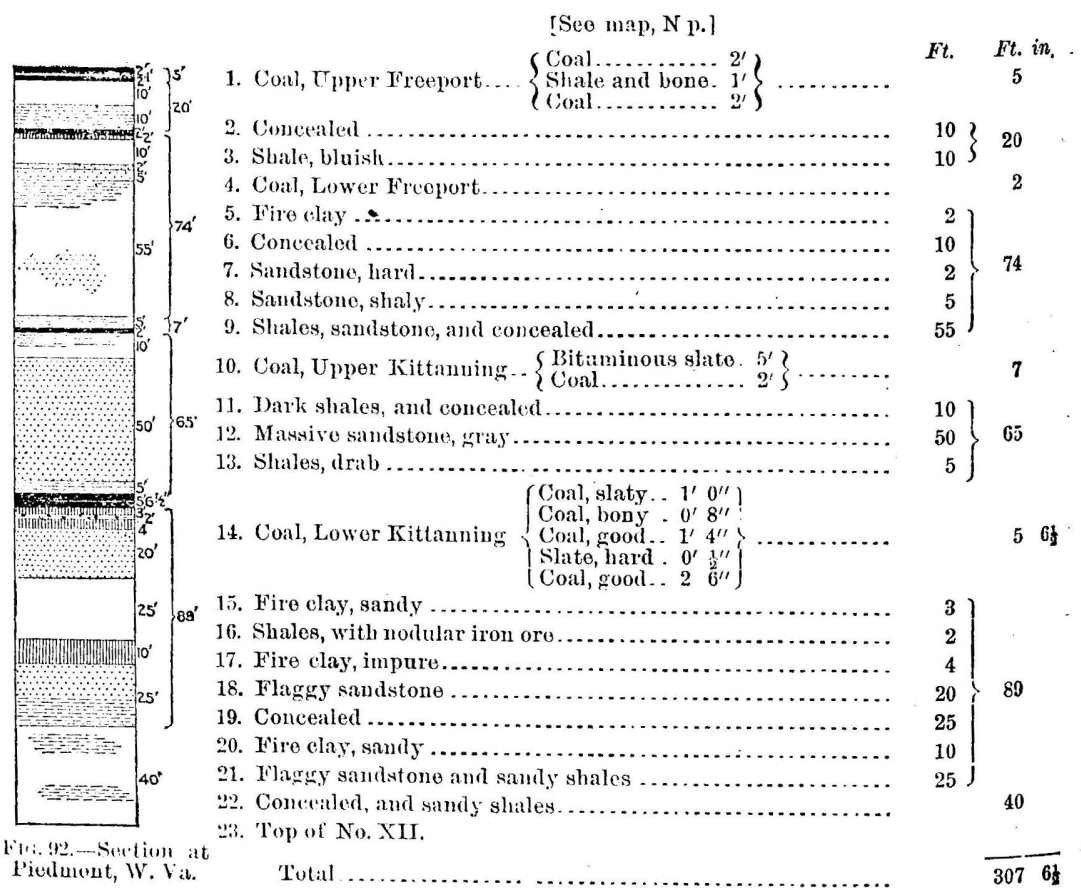


Section near Maple Swamp water tank, West Virginia Central Railroad, Mineral County, West.Virginia.-Near Maple Swamp water tank,

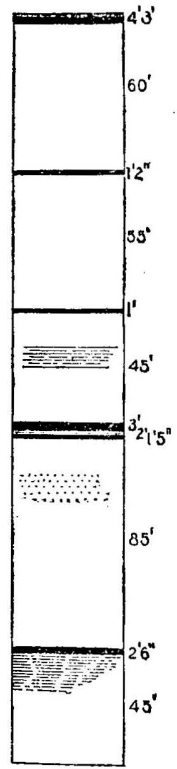
Potomacit at a pleswamp Wa ter' Tank, West Virginia Cen-
tral liailroad.
Figa.93--On North

on the West Virginia Central Railroad, Mineral County, West Virginia, these beds exhibit the following structure (Fig. 93) :

\section{On North Potomac at Maple Swamp water tank, West Virginia Central Railroad.}

$[$ See map, N p.]

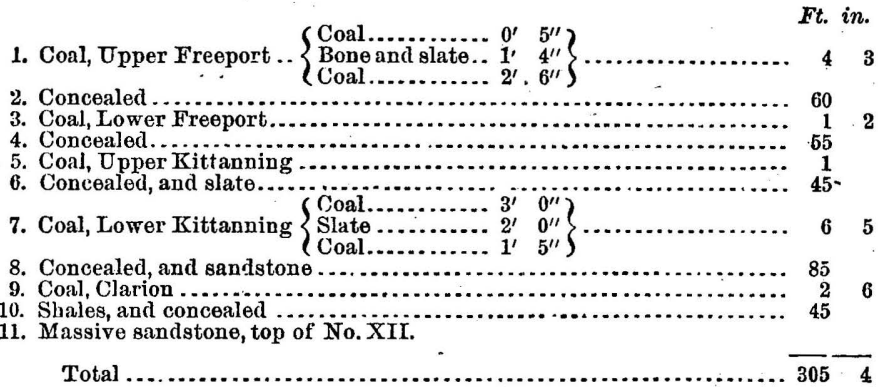

Section near Thomas, West Virginia.-At the head of the North Potomac and on the Cheat River side of the great Alleghany watershed, we get a fine exposure of the Lower Coal Measures in the vicinity of Thomas, Tucker County, West Virginia. The exposures have been made by the mining and grading operations of the West Virginia Central Railroad, and there the section reads as follows (Fig. 94):

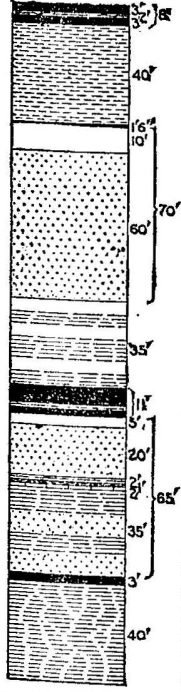

Near Thomas, Tucker County, West Firginia.

[See map, 0 o.]

1. Coal, Upper Freeport .. $\left\{\begin{array}{l}\text { Coal ................... }{ }^{\prime} \\ \text { Bone and bony coal } . .2^{\prime}\end{array}\right\} \ldots . . .$.

2. Sandy shales, weathering reddish.......................... 40

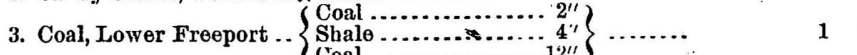

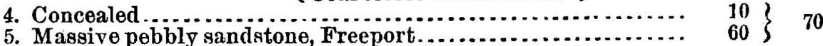

6. Coal, streak, Upper Kittanning ...............................

7. Fire clay and shales ....................................... 8. Coal; Middle and Lower $\begin{array}{lll}\text { Slate................. } & 0^{\prime} & 4^{\prime \prime} \\ \text { Coal, good .......... } 1^{\prime} & 0^{\prime \prime} \\ \text { Slate } & 0^{\prime \prime} & 3^{\prime \prime}\end{array}$ Slate............... $0^{\prime} 3^{\prime \prime}$ $\begin{array}{lll}\text { Coal, good ........... } 3^{\prime} & 6^{\prime \prime} \\ \text { Shale, gray } \ldots . . . . .1 & 1^{\prime} & 6^{\prime \prime}\end{array}$ Coal, siaty ….... $3^{\prime} 0^{\prime \prime}$

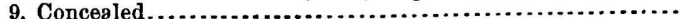

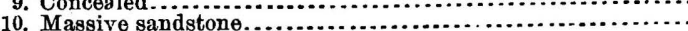

11. Shales

12. Iron ore, buhrstone

13. Limestone, ferriferous ......................................

14. Shales and sandstone

15. Coal, Clarion .................................................

Fig. 94. - N O a r

Shiles

7. Sandstone, top of No. XII.

Count iv

Total 
Section near Moatsville, Barbour County, West Virginia.-Near Moatsville, Barbour County, West Virginia, on the Tygart's Valley River,

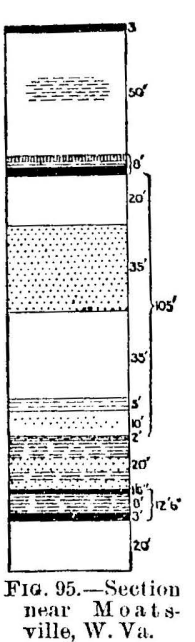
the following section of the Lower Coal Measures is exposed (Fig. 95):

Near Moatsville, Barbour County, West Virginia.

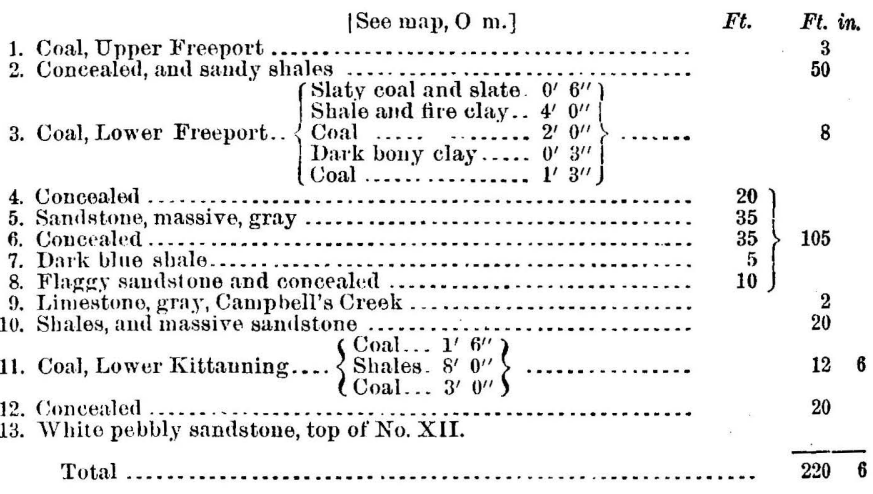

Section near Valley Falls, West Virginia.-In the vicinity of Valley Falls, Taylor County, West Virginia, where the Chestnut Ridge anti. cline brings the series above water level, the following succession is visible (Fig. 96):

Valley Falls, Taylor County, West Virg nia.

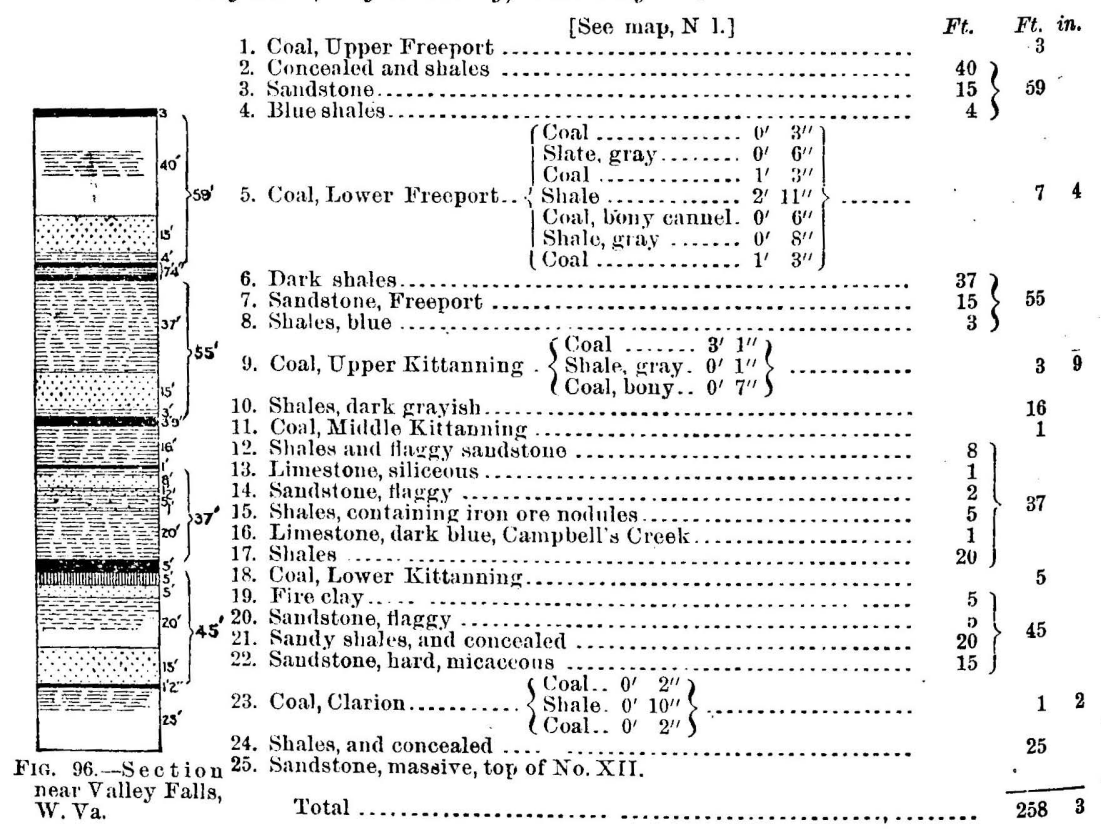

In this last section, and also in the preceding one (Fig. 95), a bed of impure, siliceous limestone occurs in the shale interval above the Low er 
Kittanning coal. It occupies the same geological horizon as the thin, siliceous limestone above the Campbell's Oreek (Lower Kittanning) coal on the Big Kanawha River, and hence I have identified it with that stratum.

Section near Nuzum's Mill, Marion County, West Virginia.-Farthor down the stream (Tygart's Valley River) the following structure (Fig. 97) was observed on the right bank, below Nuzum's Mill, Marion County, IVest Virginia:

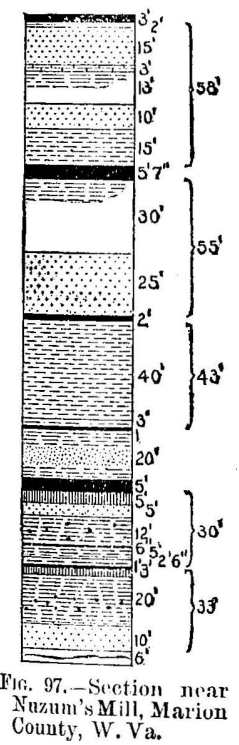

\section{Near Nuzum's Mill, Marion County, West Virginia.}

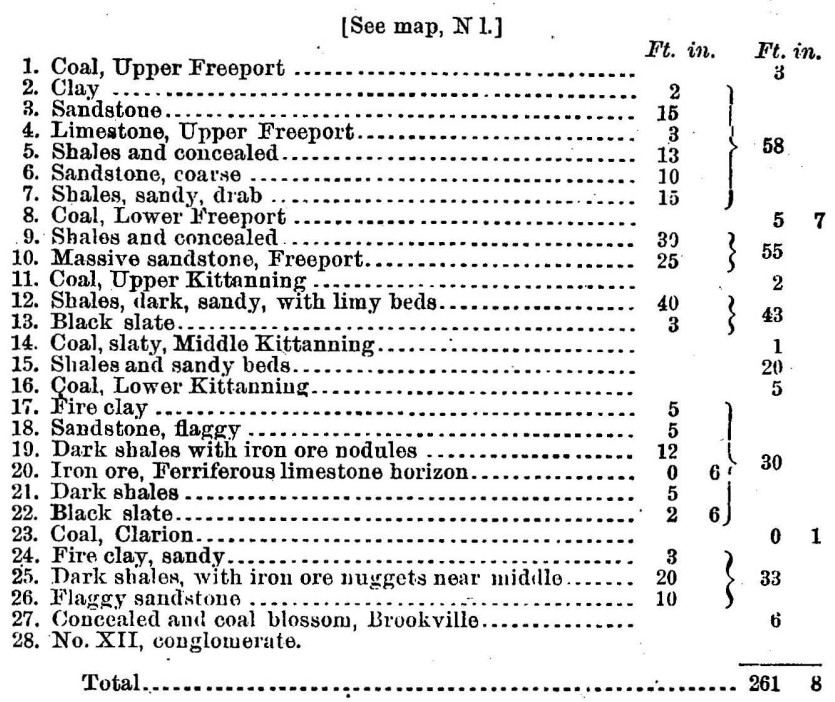

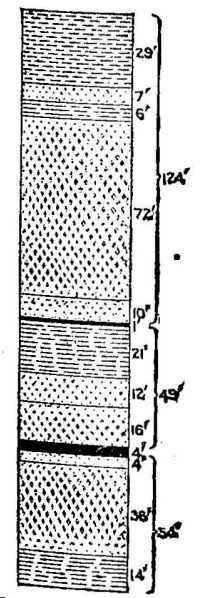

FIG. 98.-S ection W. Va.

Section under Clarksburg, West Virginia.-Frow the records of the Despard gas well boring, at Clarksburg, Harrison County, West Virginia, as furnished by 'T. M. Jackson, civil engineer, we get the structure of the Lower Coal Measures there, as follows (Fig. 98):

Under Clarksburg, West Virginia.

[See map, $0 \mathrm{k}$.]

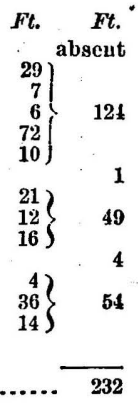

The Lower Kittanning bed is here more than 1,000 feet below the summits of the hills.

Bull. 65- 9 
Nection under Parkersburg, West Virginia.-At Parkersburg, Wood County, West Virginia, the following structure (Fig. 99) is given by the record of the Camden Consolidated Oil Company's drill

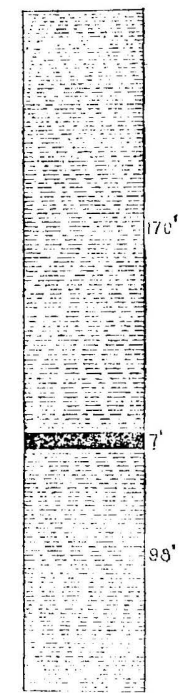

Fig. 99.- Section under Parkersburg, W. Va. hole, on the authority of $\mathrm{R}$. A. Cole, superiutendent: -

Under Parkersbury, West Firginia.

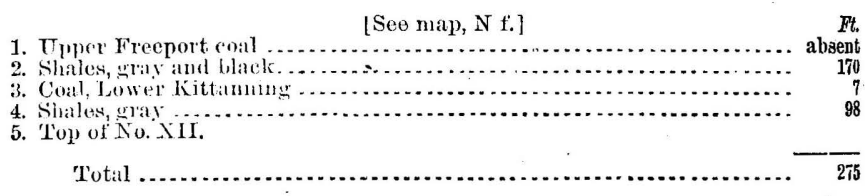

The Lower Kittanning bed is the only one in the series here, but it has a good thickmess, though lying 1,100 feet below the bed of the Ohio River, aud 1,500 feet under the surface of the hill summits.

Section under Wheeling, West Virginia.Under Wheeling, West Virginia, where the top of the series is more than 400 feet below water level, the record of the Central Glass Company's drill hole for gas gives the fol. lowing structure (Fig. 100):

Under Hheeting, Fest Virginia.

[See nap, Ir j.]

1. Coal, Upper Treeport-5.50 feet under Pittsburg coal and 450 foet undor Olio liver level

2. Sandstone and shales.

3. Coal, U!mere Kittanning

5. 'Top of No.
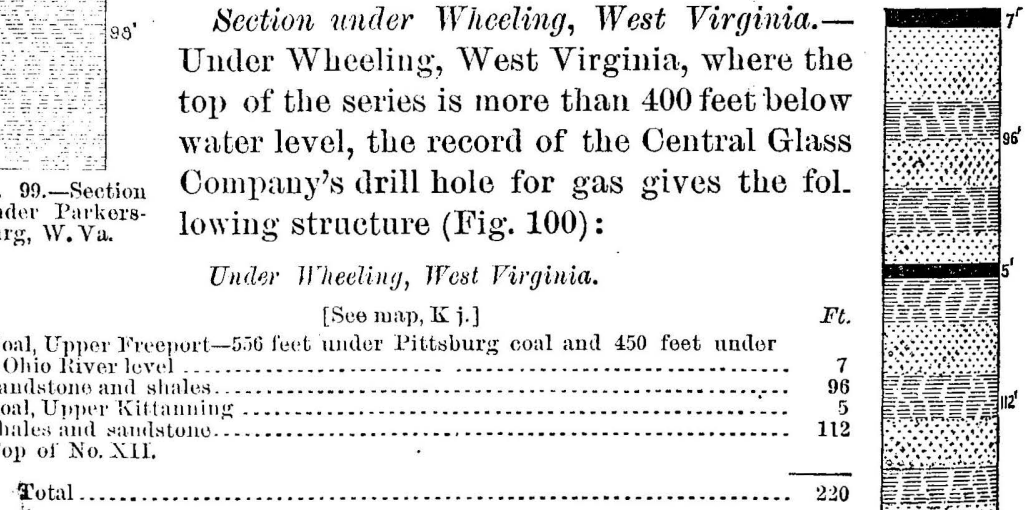
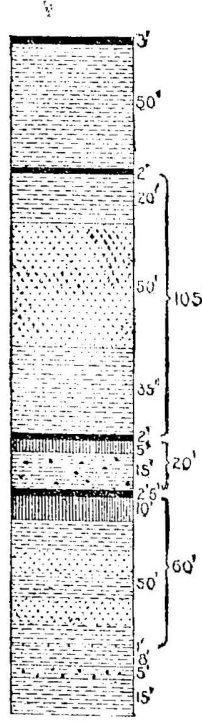

Fig. 101.-Section at mouth of Litllo Beaver.
Section at mouth of Little Beaver, on the Pennsylvania-Ohio State line.-At the Fic.100.-Section mouth of Little Beaver, on the Pennsyl- w.va. vania-Ohio State line, and the northern-point of the West Virginia "Pan-Handle," the structure is as fol. lows (Fig. 101):

Ohio and Pennsyleania line, mouth of Litlle Beaver.

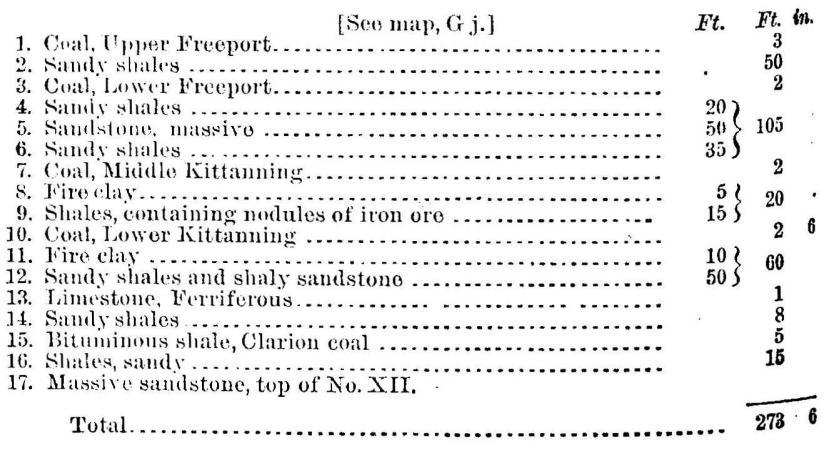


Section near Sprucevale, Columbiana County, Ohio.-Northward up the Little Beaver the column of rócks is very much the same as at the Ohio River, as may be seen from the following section (Fig. 102) taken near Sprucevale, Columbiana County, Ohio:

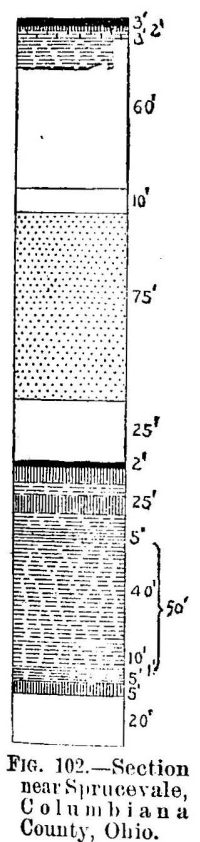

Near Sprucevale, Columbiana County, Ohio.

\begin{tabular}{|c|c|c|}
\hline [See map, G j.] & $F t$. & $F t$. \\
\hline 1. Coal, Upper Freeport ... & & 3 \\
\hline 2. Fire clay .................. & & 2 \\
\hline 3. Lixestone, Upper Freeport ........... & - & 3 \\
\hline 4. Shales, and concealed .... & & 60 \\
\hline 5. Coal, Lower Freepurt ... & blossom & \\
\hline 6. Concealed................. & & .10 \\
\hline 7. Sandstone, massive, Freeport ............ & & 75 \\
\hline 8. Coal, Middle Kittanning ................. & thin & . \\
\hline 9. Concealed.................. & & 25 \\
\hline 10. Coal, Lower Kittanning................... & & 2 \\
\hline 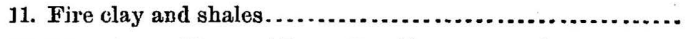 & & 25 \\
\hline 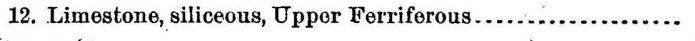 & & 5 \\
\hline 13. Shales, gray ............... & $40\}$ & \\
\hline 14. Shales, dark................................. & $10\}$ & 50 \\
\hline 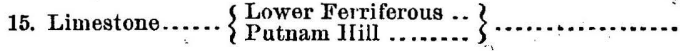 & & 1 \\
\hline (1) & & 5 \\
\hline 17. Fire clay...$\ldots \ldots \ldots \ldots \ldots \ldots \ldots \ldots$ & & 5 \\
\hline 18. Concealed, to top of No. XII ................ & & 20 \\
\hline Tote & & 91 \\
\hline
\end{tabular}

Here we get the beginning of an important feature in Ohio Lower Coal Measure stratigraphy, viz: a duplication of the Ferriferous limestone. The lower bed, No. 15, occupies the regular horizon of the Pennsylvania "Ferriferous" bed, but there comes in above it here a stratum, No. 12, of siliceous limestone, not seen anywhere in Pennsylvania, but becoming the ore-bearing limestone of the Obio series, and known as the "Gray" limestone, the ore on its top being of the same character as the Buhrstone ore of Pennsylvania and apparently identical with it.

Prof. Orton, director of the Ohio Geological Survey, thinks that on entering Ohio the Great Ferriferous limestone of Pennsylvania splits into two portions, the upper part representing the "Gray" limestone and the lower or blue portion of the Ferriferous representing the "Putnam Hill" bed of Ohio. This seems to be the most probable view of the matter, though it is barely possible that the lower or Putnam Hill stratum is an entirely new deposit, and has no representative in Pennsylvania, or this may be true with reference to the upper limestone, No. 12. 
Section between New Lisbon and Leetonia, Ohio.-In going northwestward from Sprucevale, a very rapid change takes place in the lower portion of the column, since it rapidly contracts, as will be seen from the following section (Fig. 103), made in the vicinity of the cement works, between New Lisbon and Leetonia, Ohio:

Between New Lisbon and Leetonia, Ohio.

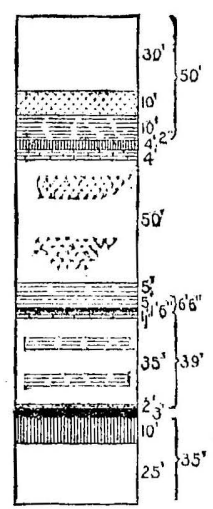

Fig. 103.-. Section be tween New I,islon and Leetonia, Obio.
[Soe nial, Gi.]

[See

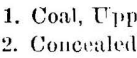

(n)

Simlstour

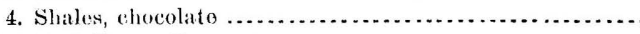

5. Coal, Lower freojort.

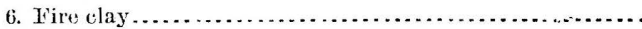

7. Limestone, Lower Freeport

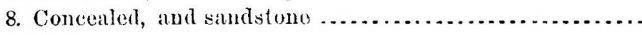

9. Shialos

10. Cual, Lower Krittanning.. $\left\{\begin{array}{lll}\text { Camnel slate } \ldots . .5 & 5^{\prime} & 0^{\prime \prime} \\ \text { Coal ............ } & \mathbf{1}^{\prime} & \mathbf{6}^{\prime \prime}\end{array}\right\} \ldots$

11. Slitte.

12. Limestone and iron ore, Upper Ferriferons.............

13. Concealed, and shales

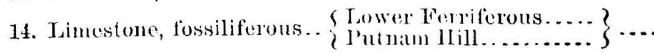

15. Coal, Clarion

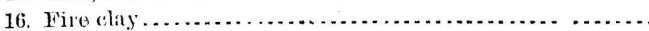

17. Iuterval to top of $\mathrm{No}$. XII

'Tutal.
F't. Ft. in.

$\left.\begin{array}{l}30 \\ 10 \\ 10\end{array}\right\} 50$

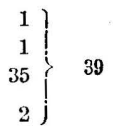

3

$\left.\begin{array}{l}10 \\ 25\end{array}\right\} 35$

$\overline{196} 8$

Section near Zanesville, Ohio.-In the vicinity of Zanesville, Muskingum County, Ohio, the section of the Lower Coal Measures reads as follows (Fig. 104), at the type locality of the Putuam Hill limestone (Vol. V, Ohio Geology, p. 96) :

Zuncsville, Mushingum County, Ohio.

[Seo map, K e.]

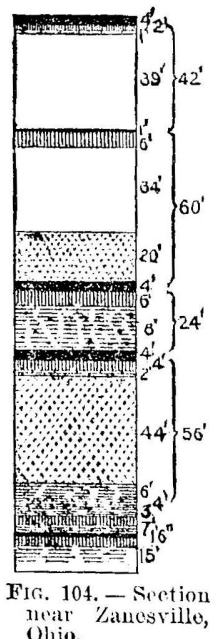

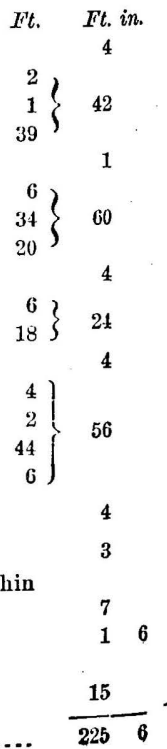
1. Coal, Upper Freeprort.

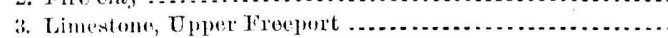

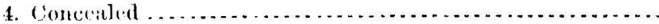

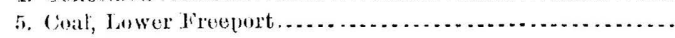

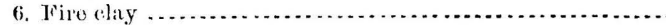

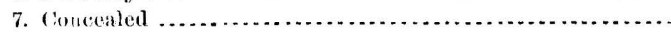

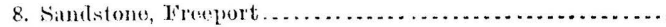

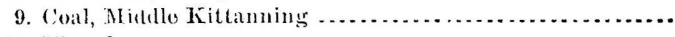

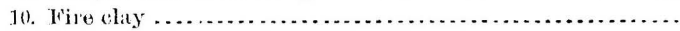

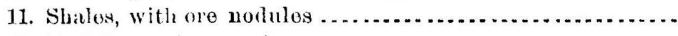
12. Coal, Lower Kittanning . . . . . . . . . . . . . . . . . .

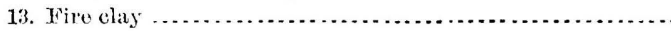

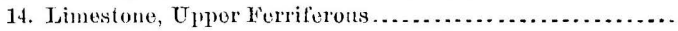

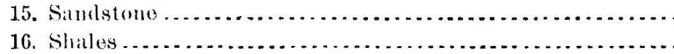

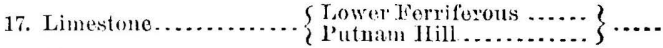

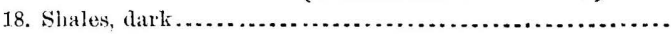

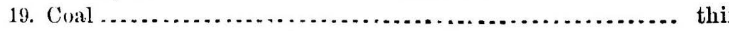

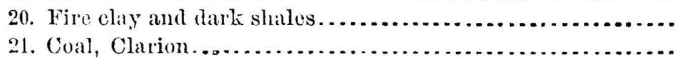
2. Firo clay, shales, and concealed, to base of Lower Coal

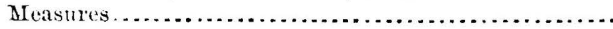


Section near Shaconee and McCuneville, Ohio.-In the ricinity of Shawnee and McCuneville, Perry County, Ohio, these beds exhibit the following structure (Fig. 105):

Vicinity of Shawnee and McCuneville, Perry County, Ohio.

[See map, M d.]

1. Coal, Tpper Freoport (not seen)

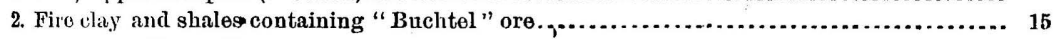

3. Limestone, Upper Freeport ..................................................... 2

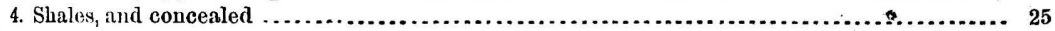

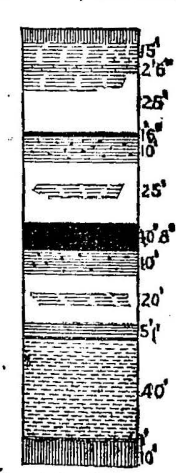

FIs. 105.-Vicinity

of Sliawnee and

MoCunerille,

Perry County

5. Coal, Lower Freeport.

6. Clay, with iron ore ............................................. 10

7. Concealed, and shales ........................................ 25

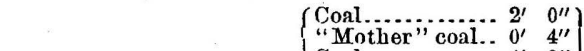

$\begin{array}{lll}\text { Coal............... } & 4^{\prime} & 4^{\prime \prime} \\ 0^{\prime \prime}\end{array}$

8. Coal, Middle Kittanning $\left\{\begin{array}{lll}\text { Bony coal } \ldots . . . . . .0 .0^{\prime} & 6^{\prime \prime} \\ \text { Slate, dark gray. } 0^{\prime} & 3^{\prime \prime}\end{array}\right.$

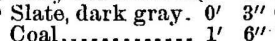

Slate................ $0^{\prime} 1^{\prime \prime}$

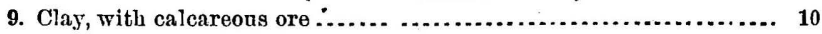

10. Concealed, and shales............................................ 20

11. Coal, Lower Kittanning ........................................

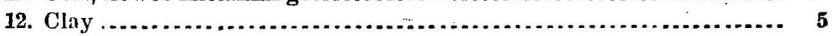

13. Ferriferons ore and flint....................................... 1

14. Sandy shales..................................................... 40

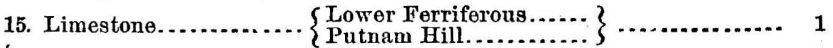

16. Fire clay .................................................. 10

17. Massive sandstone; top of No. XII.

Section near Buchtel, Ohio.-In the vicinity of Buchtel, at the line of Hocking and Athens Counties, the Lower Coal Measures exhibit this structure (Fig. 106) :

Hocking Valley, near Buchtel, Athens County, Ohio.

[See map, N c.]

Ft. Ft. in.

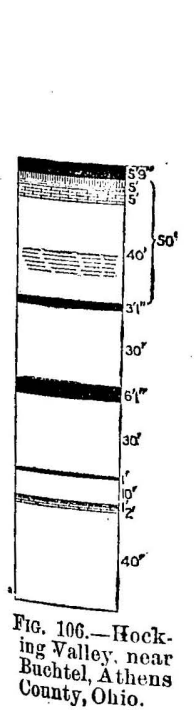

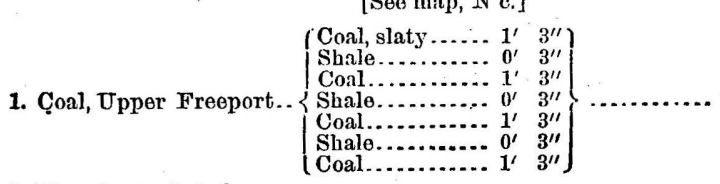

2. Fire clay and shale

3. Limestone, Freeport.

4. Concealed, and shaies

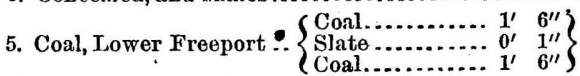

$\left\{\begin{array}{l}\text { Slate } \\ \text { Coal. }\end{array}\right.$

6. Concealed

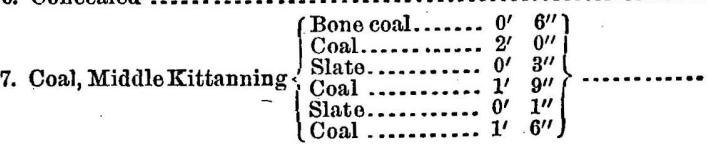

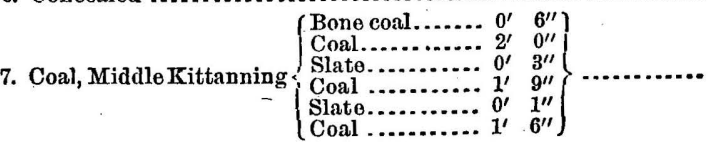

$\left.\begin{array}{r}5 \\ 50\end{array}\right\}$

8. Concealerl :

9. Coal, Lower Kittanning

10. Concealed

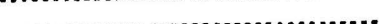

12. Limestone, Ferriferons . . . . . . . . . . . . . . . . .

13. Interval to top of No. XII.

Total. 
Section on Meeker's Run, near Nelsonville, Ohio._On Meeker's Run, near Nelsonville, Athens County, Ohio, the structure of the Lower Coal Measures is thus (Fig. 107) given by Prof. Orton in Vol. III, Ohic Geology, page 926 :

On Meeker's Run, near Nelsonville, Athens County, Ohio.

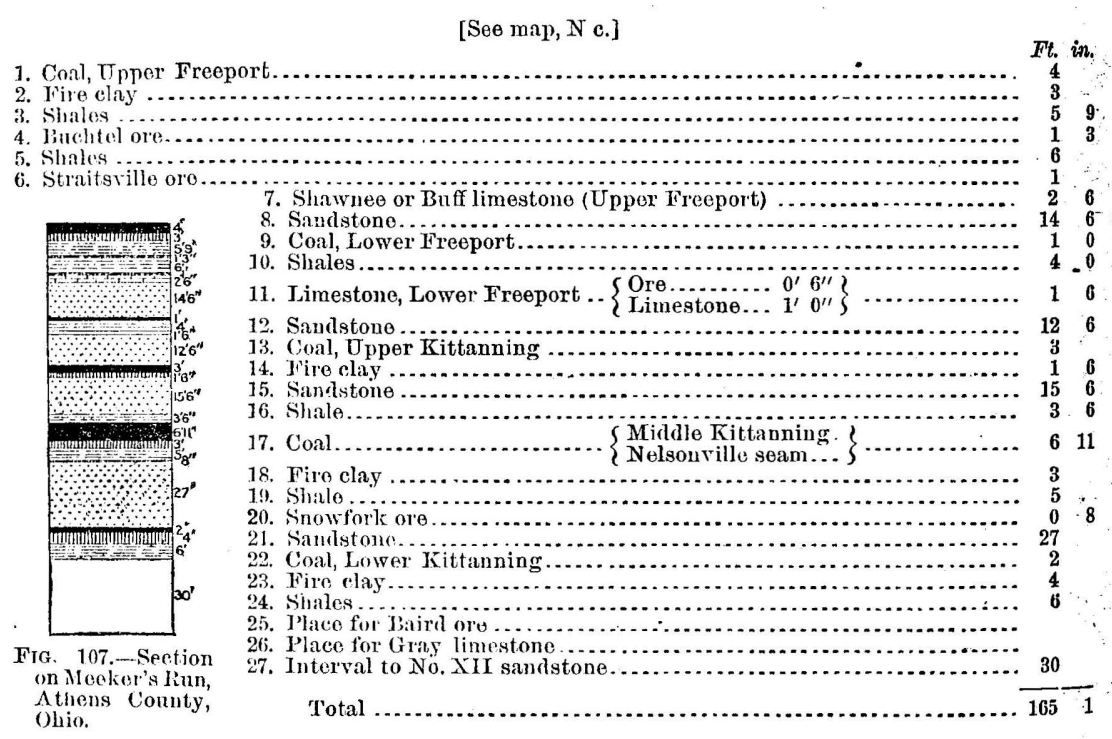

Section at Panther Mill, Scioto County, Ohio.-Farther to the southwest, in Panther Hill, near Mt. Vernon Furnace, Scioto County, Ohio, these rocks are given as follows (Fig. 108) in Vol. V, Ohio Geology, p. 1038:

Panther Mill, Mt. Vernon IH.rnace, Scioto County, Ohio.

[See map, Q a.]

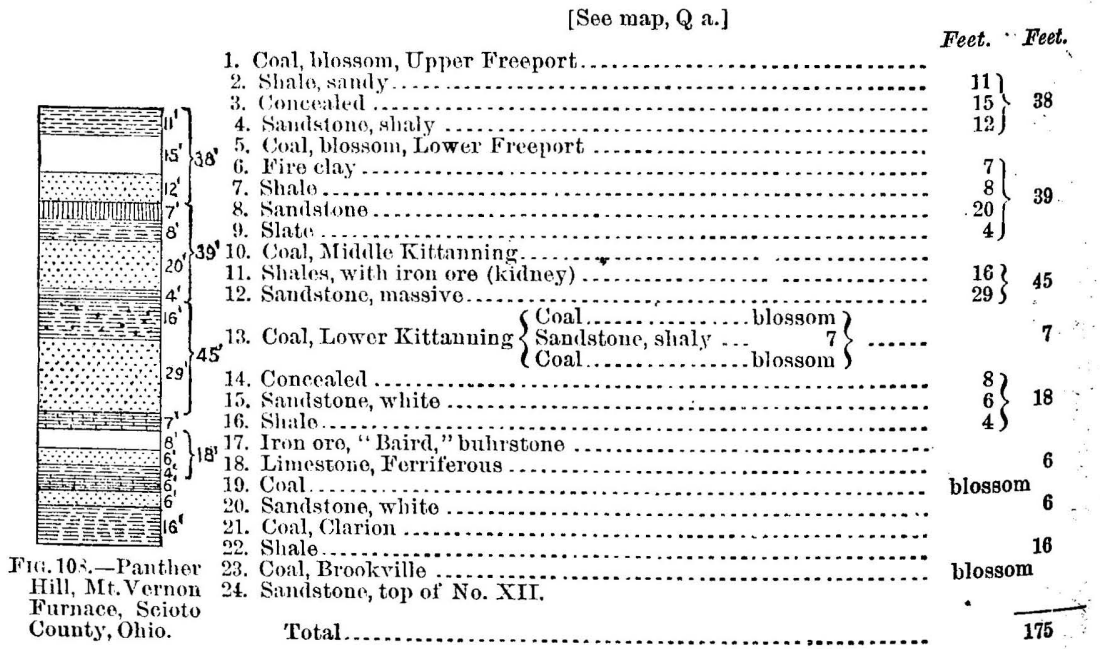


Section near Ironton, Ohio.-From the vicinity of Ironton, Ohio, Prof. Orton reports the following structure (Fig. 109) for the Lower Coal

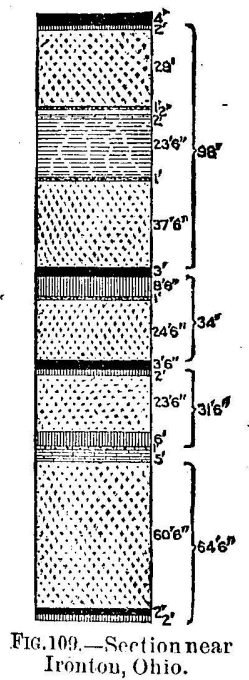
Measures (Vol. III, Ohio Geology, p. 928):
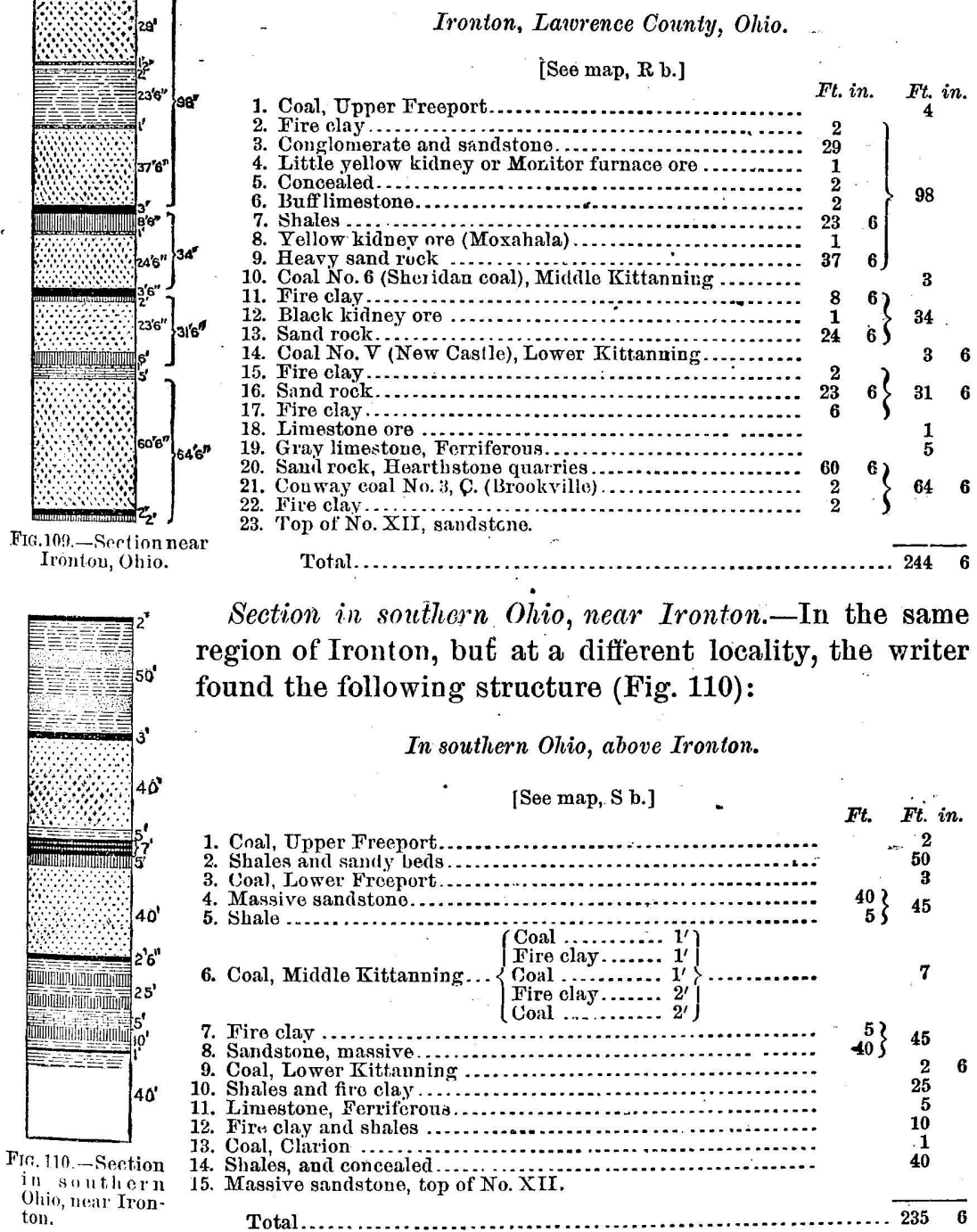

Section in southern Ohio, near Ironton.-In the same region of Ironton, but at a different locality, the writer found the following structure (Fig. 110):

In southern Ohio, above Ironton.

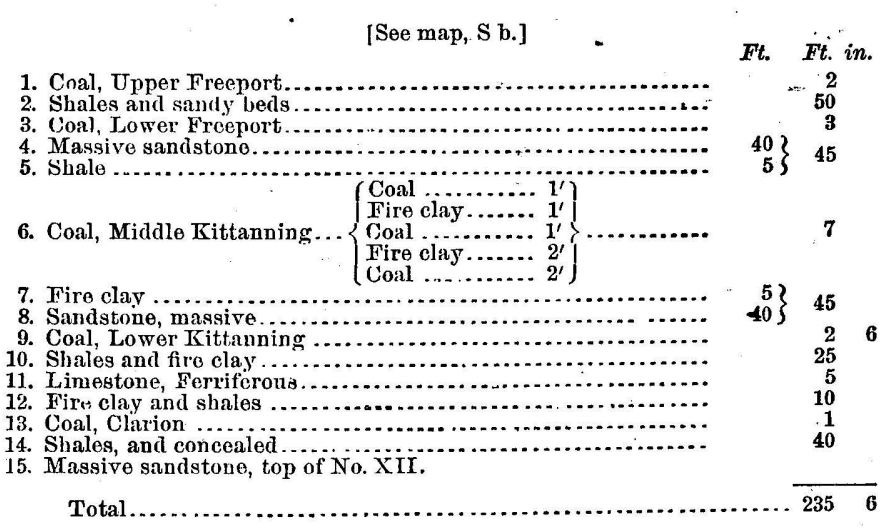

This section differs but little from that found in western Pennsylvania. The "Buhrstone" or "Baird" ore, which was not noted in this, is present itr other sections at its proper horizon on top of No. 11. The Putnam Hill, or lower division of the Ferriferous limestone, seems to have disappeared, either by coalescing with the upper one or failure of deposition, and the same appears to be true of the Upper Kittanning coal, unless it is to be found in the upper layers of the complex Middle Kittanning No. 6, which is not improbable. 
Section at Charleston, West Virginia.-As we leave the northwestern margin of the Appalachian field in southern Ohio, and pass southeast-

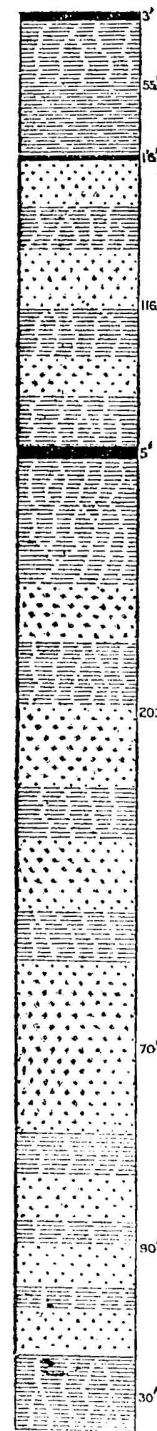

Fif. 111.-.-Section under ('harles. ton, W. Va. ward toward the other or eastern side of the same, the Lower Coal Measures thicken up quite rapidly, as will be seen from the line of sections which will now be given along the Great Kanawha River. The following one (Fig. 111), from the mouth of Elk River, at Charleston, is the record of Edwards gas well No. 3. It begins at the level of the Upper Freeport coal, and the record was obtained from Mr. W. S. Edwards, the superintend; ent of the gas company :

Under Charleston, Fanawha County, Test Virginia, by bore hole near mouth of Elk River.

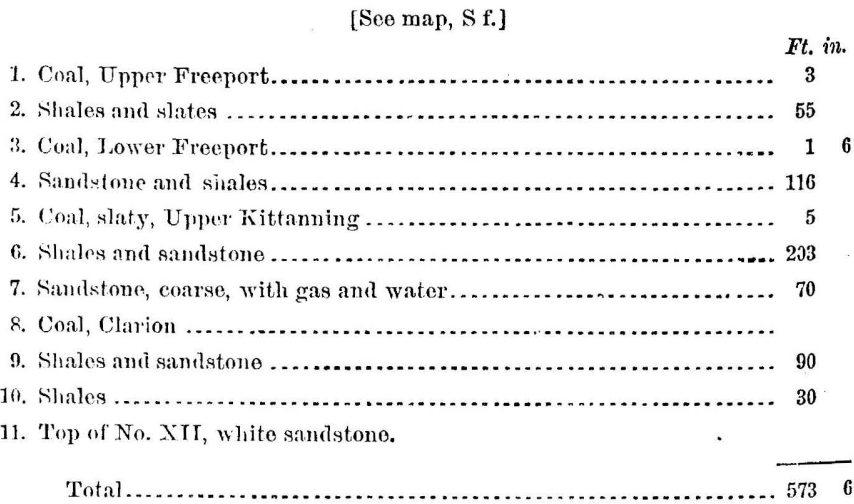

The thickness of the measures is here about three times greater than in the Hocking Valley, 100 miles north from Charleston. Just where this rapid thickening begins has not yet been determined, owing to the absence of reliable borings between the Hocking Valley and Charleston, but it is probable that the most of it comes in from the Ohio River sonthward to Charleston, since the borings at Pomeroy and Hartford City disclose 110 unusual thickness of the Lower Coal Measures.

The identification of coal No. 8 in the above section is open to question, as it may possibly represent the Lower Kittanning bed.

There may have been other beds of coal passed througb by the drill in the well from which this section is taken, since it is seldom that drillers for oil and gas exercise much care in ex. amining the drillings for coal. 
Section at mouth of Lick Run, near Charleston, West Virginia.-Near the mouth of Lick Run, 2 miles south of Charleston, a well was

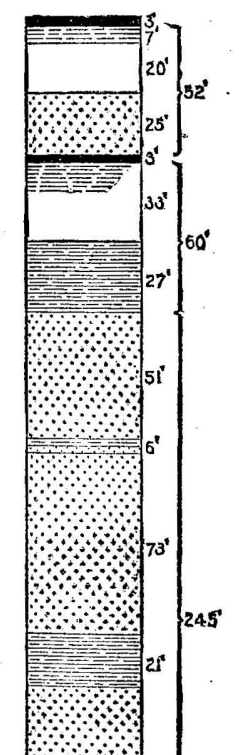
bored for gas, by Mr. Hulings, and from the superintendent, Colonel Jordan, I obtained the following record (Fig. 112) by combining it with the 70 odd feet of rocks exposed above the mouth of the boring :

At mouth of Lick Run, two miles above Charleston, Kanawha County, West Virginia.

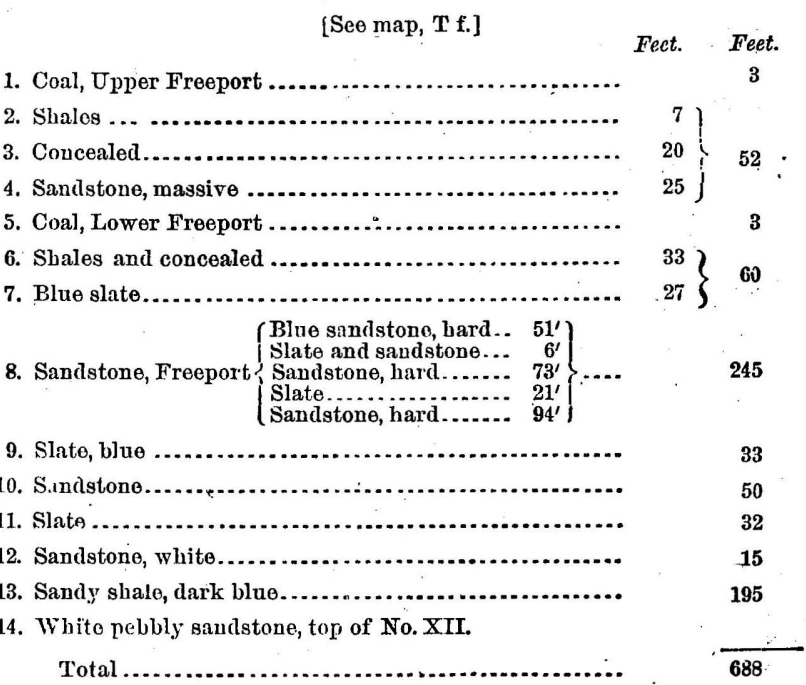

Colonel Jordan states that no particular search was made for coal here, and hence several beds may have been passed unnoticed. It is also possible that the top of No. XII is placed about 100 feet too low by the section above, since the ordinary driller frequently neglects to note changes in the character of the strata through which the drill passes; hence it is quite probable that a considerable thickness of No. 13, which the drillers called "sandy shale," may have been really the top portion of the No. XII series.

The Freeport sandstone, No. 8, exhibits an unusual development here, and it is possible that the lowest division included in No. 8 is not really a member of this stratum, but belongs lower in the series.

No. 10 is probably a representative of the Kittanning sandstone. 
Section at Dichinson salt works, Kanauha County, West VirginiaIn the vicinity of Malden, 6 miles above Charleston, the rapid rise of the strata on the northw estern slope of the Brownstown anticlinal bas

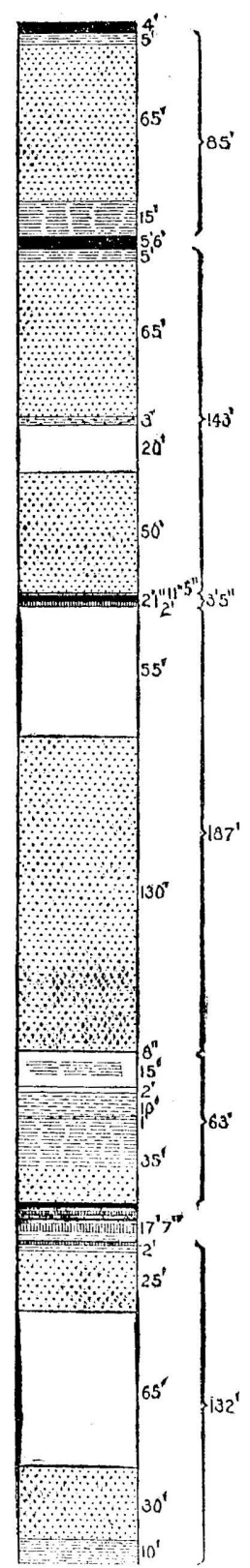

Fir. 113.--Section at lickinsom silt works, Kamawha Cumnty, W brought nearly all of the Lower Coal Measures to the surface, and the rest of the column is supplied from the records of the Edwards gas well No. 2, at the Dickinson salt works. The combined section reads as follows (Fig. 113):

Dickinson salt works, Kanawha County, W st Vivginia.

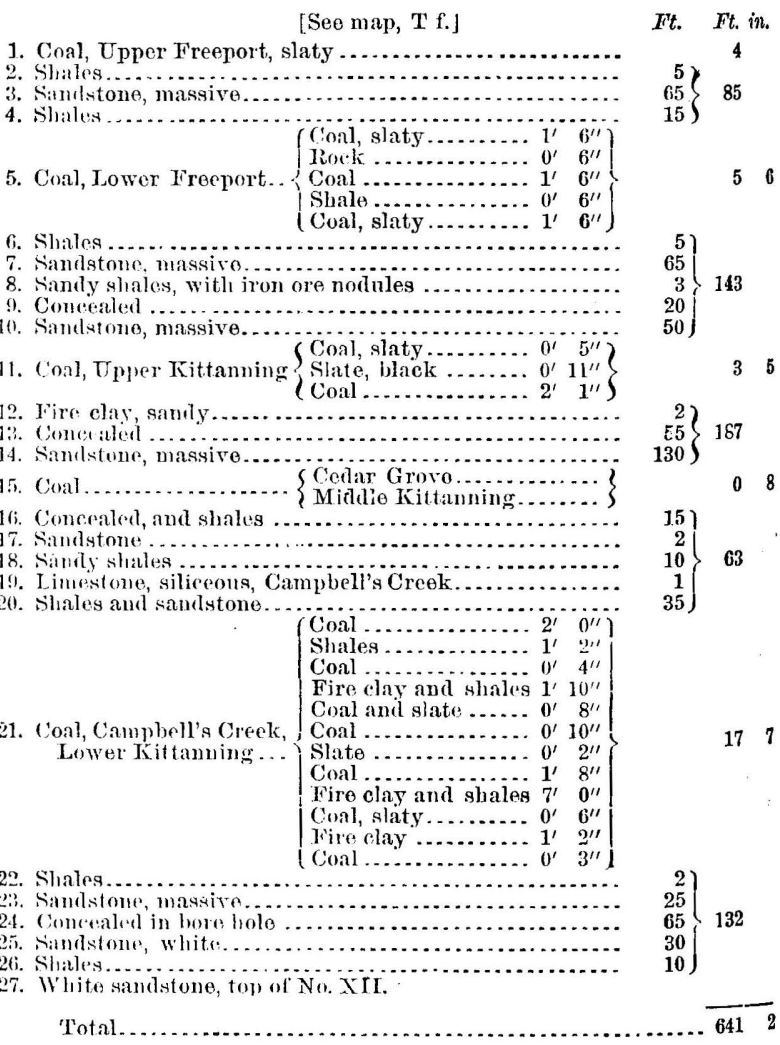

This section would seem to confirm the statement made in connection with the Lick Run boring, viz, that a part of the last interval given there should more properly be credited to No. XII, the next series below the Lower Coal Measures.

The Camplell's Creek, or Lower Kittanning coal, is here very much split up with slate and shales, but on the Malden side of the Kanawha it is a good bed, from which 4 to 6 feet of coal is obtained with only the two parting slates.

This is the type locality of the Campbell's Creek limestone No. 19. 
Section near Brownstown, West Tirginia.-In the vicinity of Brownstown and near the Burning Spring, 9 miles above Charleston, another

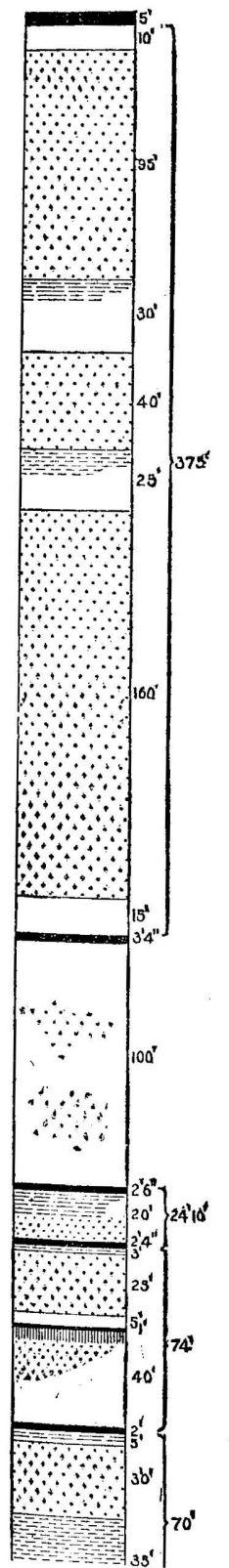

FIG. 114.-. Section near Brownstown, three miles south from Malden, W. Va.

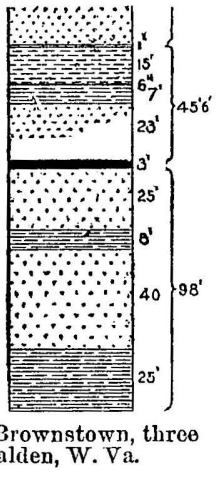
gas well was drilled (Edwards No. 1) and its record combined with the surface exposures in that vicinity gives the following succession (Fig. 114):

Near Brounstown, three miles south from Malden.

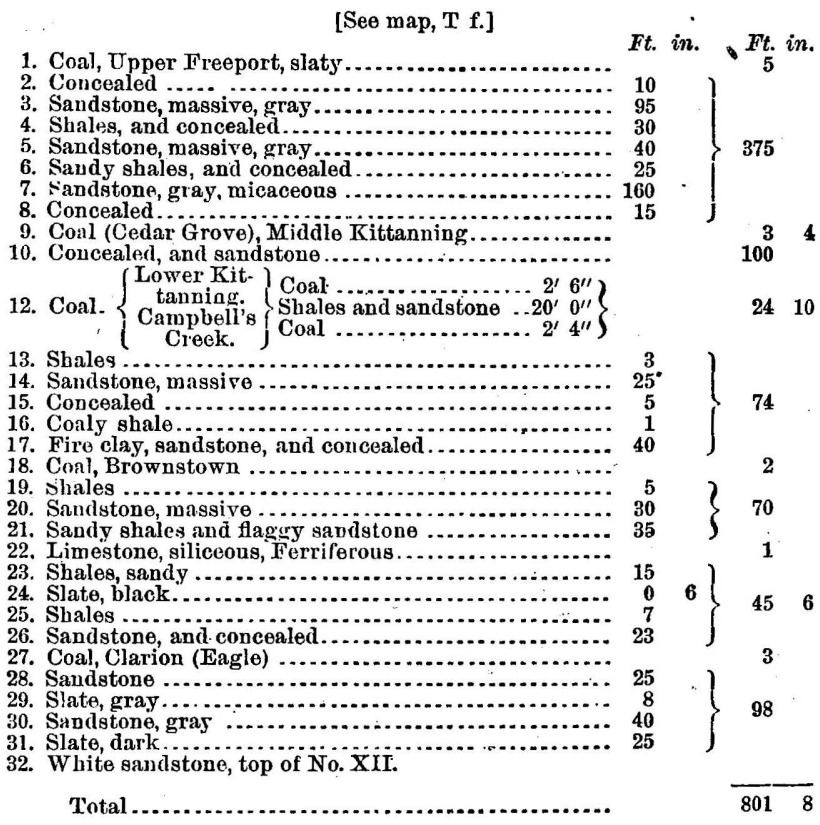

The only part of this series dependent on the bore bole record is the last $\mathbf{1 0 0}$ feet, or that from the Clarion coal down, the rest of it all being exposed above the bed of the Kanawha in the region of Brownstown.

By comparing this with the Charleston section (Fig. 111) it will be seen that the whole column has thickened southward at the rate of about 25 feet to the mile. It will also be observed that with this thickening a new coal, the Brownstown, makes its appearance in the series. This is one of a local group of two or three coals which appear in the column of rocks around the southeastern margin of the coal field between the Lower Kittanning bed and the Ferriferous limestone, which would seem to be represented by No. 22 of the section. These coals are of little economic importance, as they are usually thin and slaty. 
Section at mouth of Armstrong Creek, on the Big Kanawha River, West Virginia.-At the mouth of Armstrong Creek, 25 miles south from Charleston, the whole column of the Lower Coal Measures is above

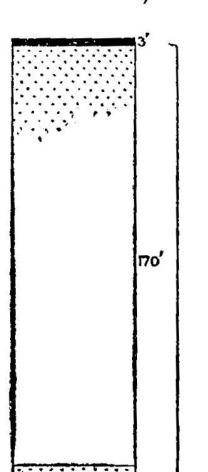
water level, and a high point almost vertically abovo the Kanawha River catches the top members of the same, so that here a very fine exposure of the serim gives the following structure (Fig. 115):

Mouth of Armstrong Creck, on the Big Kanawha River. [See map, U g.]

Uper Freeport

. Sandstome, amil concealed.

4. Concealed and samditomo.

. Limestone, siliceous ..-.

2

6. Sandstone, massive, gray

7. Coal. \{ Middle Kittanning. coal. Shate..... $6^{\prime \prime}$ Shalo..... $5^{\prime \prime}$ Coal........ $4^{\prime \prime}$

8. Fire clay, and conceale

16. Sandy shales (Coal ........... $1^{\prime} 1^{\prime \prime}$ Slate.......... $\left.0^{\prime} 1^{\prime \prime \prime}\right\}$

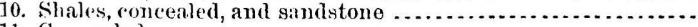
11. Concealed

12. Sumlstome and shales. 13. Sandstone, massive

Sandy shales

Coal "Parerlegs".

Shales, bluish. Coal,

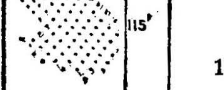

ning............... \},

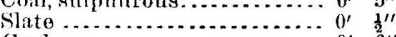

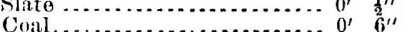

Coatl, splint ..................... $0^{\prime} 11^{\prime \prime}$

Partiner.......... $0^{\prime} z^{\prime \prime}$

Coal ......................

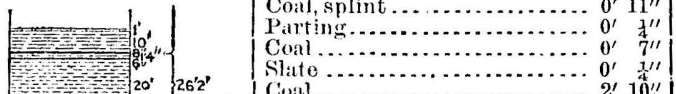

8 Coin ...........

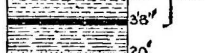

19. Saudstoue aud slialeg

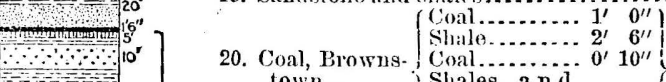
town....... Shales and

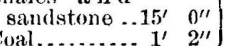

21. Concealed, anci sandy shales.........

22. Limest one, siliceoms, Ferriferous .... . .

23. Shale

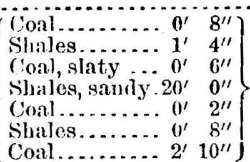

24. Coal, (larion $\mid \begin{array}{llll}\text { Shol, slaty } \ldots . . & 0^{\prime} & 6^{\prime \prime} \\ \text { (Collat }\end{array}$ (Eagle) ..... S Shales, sandy . 20 $0^{\prime} 0^{\prime \prime}$

25. Shales and sandy beds................

26. Coal, Little Eaglo....................

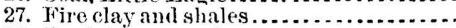

28. Sandstone,

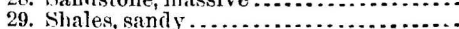

30. Limestone, fossiliferous, Faglo .........

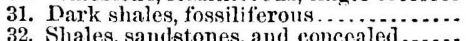

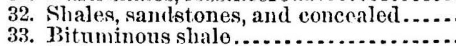

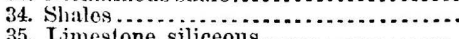

36. Shales, sandstone, and concealed.......

37. Sandstone, massive, top of No. XII.

Total
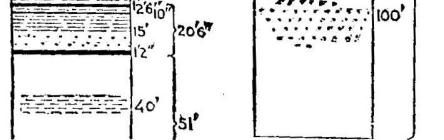
Here both the Lower Kittanning and the Clarion coals show in their structure the effect of the general thickening up of the whole column of rocks. Three miles north from this, the Clarion or Eagle coal is a good bed, which, with its partings of slate, is only $4 \frac{1}{2}$ feet thick, but the partings gradually thicken and new ones come in till the structure shown in No. 24 is obtained.

A small coal which has been termed the Little Eagle comes into the section in this region, and seems to have a wide distribution around the sonthern margin of the coal field. It is a very pure coal and may be a lower member of the Clarion bed.

The Eagle limestone, No. 30, was named from a mining village 3 miles below the locality of this section, where it is finely exposed in the cuts of the Chesapeake and Ohio Railroad. It and the shales below it are crowded with the Lower Coal Measures fossils, the general facies of the fauna being very similar to that found in connection with the Ferriferous limestone in western Pennsylvania, but the general section forbids the supposition that it is identical with the latter. At one time I entertained the idea that it might be the representative of the Putnam Hill limestone, of Ohio, but a closer study of the Ohio section renders that hypothesis untenable, since the Putnam Hill bed belongs above the Clarion coal and not below, as does the Eagle limestone.

No. 33 is a very bituminous shale, since lubricating oil was once manufactured therefrom, and it may possibly represent the Brookville coal of Peunsylvania.

A comparison of this section with those on the other side of the Appalachian basin at Buchtel.(106) and Shawnee (105) will show the wonderful expansion of these beds from $\mathbf{1 7 5}$ feet at the latter localities to a thickness of more than 1,000 feet at Armstrong's Creek, and the same thing is shown graphically in map, Section C. That such a great expansion of these measures should show only the. same number of workable coal beds as the section at Shawnee was hardly to be expected, but it is true beyond question. The coal beds themselves give evidence of this great expansion of the general column in the slates and other impurities with which they are interstratified.

The interval (165 feet) which here separates the Middle and Lower Kittanning coal beds appears excessive, since it is only 100 feet a few miles below, but there can be very little doubt of the figures given, and as there are no coal beils between Nos. 7 and 17, it is evident that No. .7 must be the Middle Kittanning.

The top member of the Pottsville conglomerate is in the bed of the Kanawha, where the section shown in Fig. 115 ends. 
Section at Guyandotte Mountain, Raleigh County, West VirginiaThat the Lower Coal Measures keep their greatly expauded measure. ment on southwestward from the Kanawha River is shown by the fol. lowing section (Fig. 116) made by Captain Miller, chief engineer of the Trans-Flat-Top Land Association. It begius at the summit of Guy.

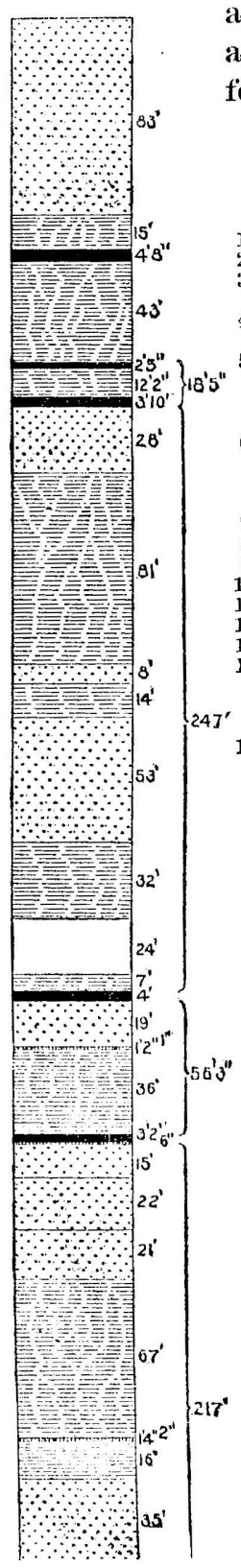

Fig. 116._. Section at Guyamlot te Mountain, Raleigh County, W. Va. foot of the mountain :

2. Massive sandstone

3. Shates .-

5. Shale

14. Shale, yellowish audotte Mountain, Raleigh County, West Virginia, aud was measured along the turupike eastward to the

Guyandotte Mounlain, Raleigh County, West Virginia.

[See nap, W g.]

Ft. in. Ft. in

1. Upper Freeport coal (absent)

4. Coal, Lower Freeport.. \{

$\{$ Goal

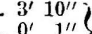

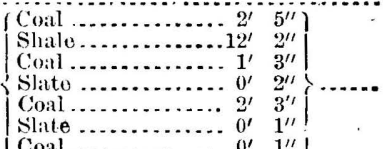

, sray

8. Shat

10. Shale

11. Sandstone, hard, gray. .

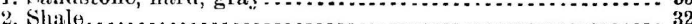

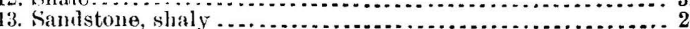

15. Coal, Lower Kittanuiug

Coal ............... $0^{\prime} 7^{\prime \prime}$

Slate $\ldots . . . . . . . . .60^{\prime} 1^{\prime \prime}$

coal....... $0^{\prime} 9^{\prime \prime}$

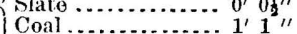

Siate $\ldots . . . . . . . . . .10^{\prime} 4^{\prime \prime}$

Coal ................. $1^{\prime} 1^{\prime} \frac{1}{2}^{\prime \prime}$

16. Samlstone, soft, yellow

17. Coal ................

18. Fire clay $\ldots \ldots \ldots \ldots \ldots \ldots \ldots \ldots \ldots$

10. Shales, yellow C Coal ...... $\left.0^{\prime} 1^{\prime \prime}\right\}$

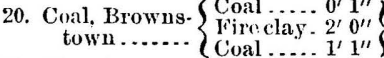

21. Fire clay .................. 0

22. Samistone, soft yellow ........ 15

23. Sandstome, hard, "ray ........

24. Sanistone, soft, yollow, micaceus 2

25. Shates, yellowish ............. 6

26. Coal

27. Fire clay

28. Slate, black -

(iii Sind stone seft yellow -

30. Shales, yellow

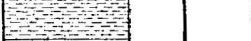

\begin{tabular}{|c|c|}
\hline & Coal ........ 1' $1^{\prime \prime} 3^{\prime \prime}$ \\
\hline & Slate ....... $4^{\prime} 0^{\prime \prime}$ \\
\hline & Fire clay $\ldots 2^{\prime} 0^{\prime \prime}$ \\
\hline & Goal ........ \\
\hline Coal, Eaglo & Clay $\ldots . . . . .0^{\prime} 3^{\prime \prime}$ \\
\hline (Clarion) & $0^{\prime} ?^{\prime \prime}$ \\
\hline & Clay \\
\hline & Clay. \\
\hline & $\ldots 0^{\prime} 1^{\prime \prime}$ \\
\hline
\end{tabular}

32. Sandstone, hard, criy ......... 13

33. Sandstone, soft, yellow ......... 33

34. Coal, Little Jaglu . . . . . . . . . . . .

35. Fire clay..

36. Slables, sand y, yellow ............ 46

37. Sandstone, soft, yellow ........ 70

38. Shales, sandy, yellowish....... 58

39. Sandstone, flaggy ............. 7

40. Shales, yellow ................

41. Pebbly sandstone, top of No. Xir.

Total. 
It is possible that the horizon of the Upper Freeport coal should have heell placed higher than the section shows, since the coal is not present and the place given it is only a surmise.

Section near Oceana, Wyoming County, West Virginia.-In the vicinity of Ocealla, Wyoming County, West Virginia, and the neighboring re-

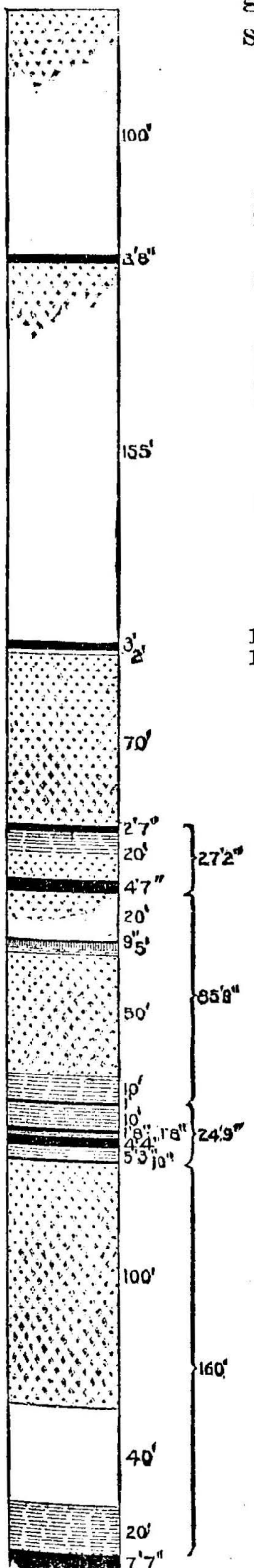
gion, the Lower Coal Measures present the following structure (Fig. 117):

Wyoming County, West Virginia.

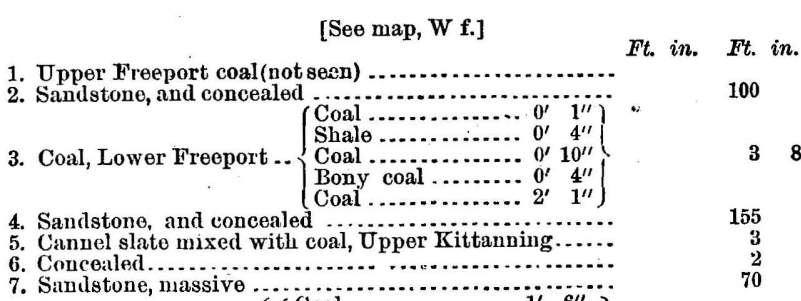

Sandstone, massive

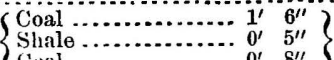

8. Coal, Middle Kit.

Coal .................

tauning...........

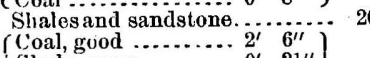

Shale, gray ........... $0^{\prime} \quad 21{ }^{\prime \prime}$

Coal ................. $0^{\prime} 3^{1 / 2}$

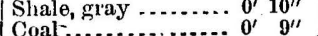

2 7)

20

9. Concealed, and sandstono.

10. Coal

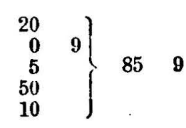

Fire clay and shales

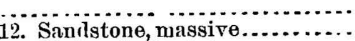

13. Shales, dark, slaty............

Coal... $1^{\prime} 0^{\prime \prime}$

Coal.. $1^{\prime} 8^{\prime \prime}$

14. Coal, Lower slate,

Kitt dark. $0^{\prime} 6^{\prime \prime}$

ning ....

Slate. 0. $\mathbf{4}^{\prime \prime}$

Coal.. $4^{\prime} 0^{\prime \prime}$

Slate. $5^{\prime} 3^{\prime \prime}$

(Coal.. $0^{\prime} 10^{\prime \prime}$

249

15. Massive sandstone

15. Massive sandstone .............. 40

17. Shalealed.

$\{160$

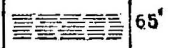

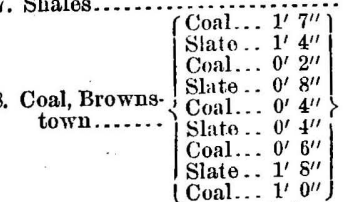

19. Sandstone, and concealed ...

20. Coal, Eagle $\left\{\begin{array}{ccc}\text { Coal.... } & 3^{\prime} & 4^{\prime \prime} \\ 0^{\prime} & 4^{\prime \prime}\end{array}\right\}$

(Clarion).. $\left\{\begin{array}{lll}\text { Slate .. } & 0^{\prime \prime} & 4^{\prime \prime} \\ \text { Coal... } & 2^{\prime \prime} & 0^{\prime \prime}\end{array}\right\}$

21. Concealed, and shales ........

22. Coal, Little Eingle .............

23. Shales and sandstones........

24. Shales, gray, with fossil plants

25. Coal.........................

stone.........................

29. Masaive sandstones, top of

No. XII.

Total

100

30

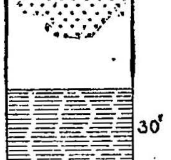


No. 20 is known as the "coking coal" in the Wyoming region, since it has the typical structure of such coal, and looks very much like the same (Lagle) bed on the Kanawha.

The Little Eagle bed No. 22 is also very good coal here, and its in. terval below the main seam has increased from 20 to 65 feet.

Section at mouth of Blaine Creek, Lawrence County, Kentucky.-In

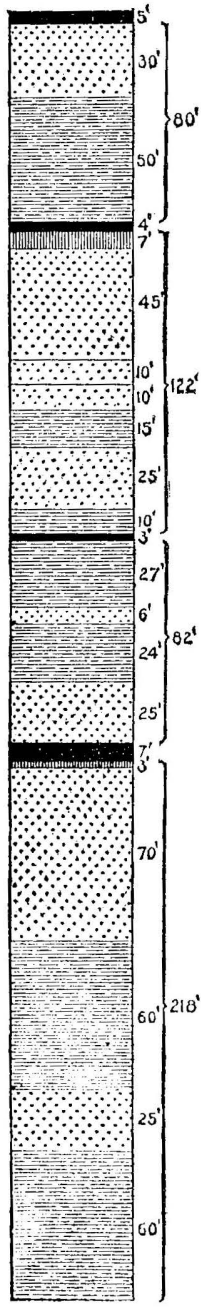

Fic. 118.-... Section at mouth of Bla ino Crook, Ky. passing southward up the Big Sandy River, at the southwestern line of West Virginia, the Lower Coal Measures thicken up at about the same rate as they do along the Kanawha, as will be seen from the follow. ing sections. The first one (Fig. 118) is from a sur. face measurement, combined with the record of Rigdon gas well No. 2, at the mouth of Blaine Creek, 20 miles above the mouth of the Big Sandy River, and reads as follows:

Mouth of Blaine Creek, tuenty miles above mouth of Big Sandy River, lientucky.

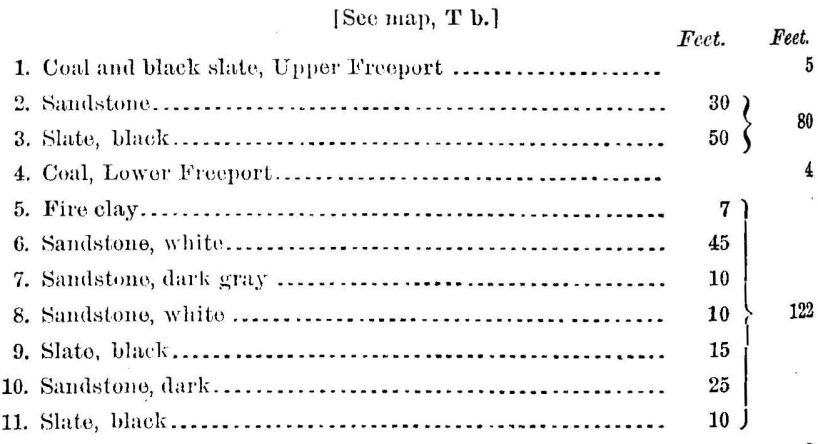

12. Conl, Mildle Kittanning..............................

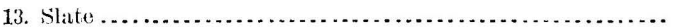

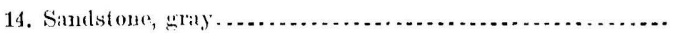

15. Slite, hlarek

16. Sablsteme, gray .........................................

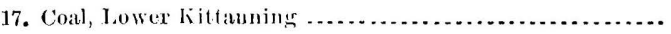

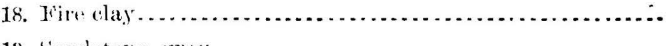

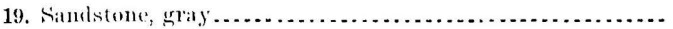

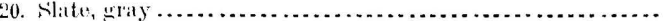

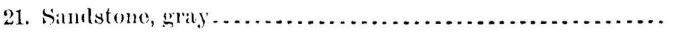

22. Slato, llakk.

23. Simlstone, white, fop of No. XII.

Total.

For the carefully kept record of this boring I am indebted to Mr. F. H. Oliphant, now the chief geologist of the South Penu Oil Company. 
Section near Old Peach Orchard, Lavrence County, Kentucky.-In the vicinity of Old Peach Orchard, on the Louisa fork of Big Sandy

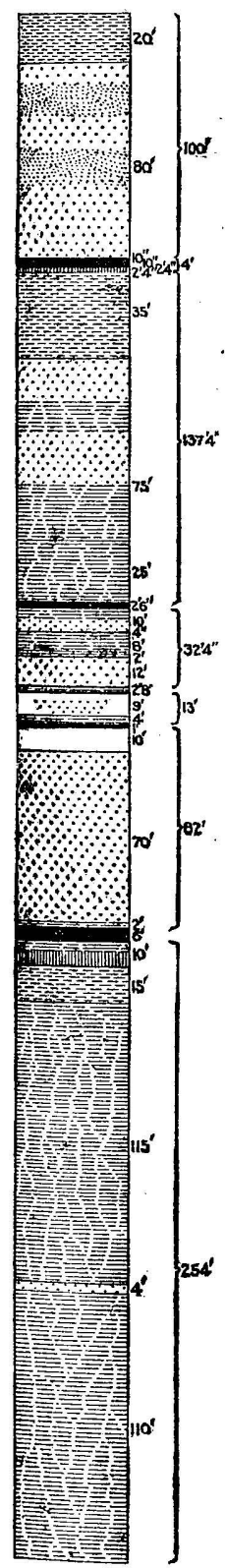
River, Kentucky, the surface measurements, combined with the records of oil and gas borings near by, give the following structure (Fig. 119):

\section{Near Peach Orchard, Kentucky.}

[See map, V b.] Ft. in. Ft. in.

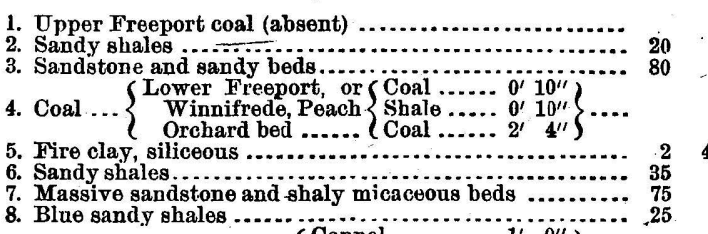

9. Coal, Upper Kittanning $\left\{\begin{array}{lll}\text { Cannel.............. } & 1, & 0^{\prime \prime} \\ \text { Clay.............. } & 0^{\prime \prime} & 6^{\prime \prime}\end{array}\right\}$

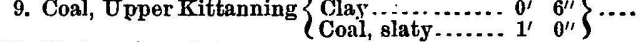

\} 100

10. Shale and sandstone .................................. 10

11. Coal ............................................... ${ }_{0}$

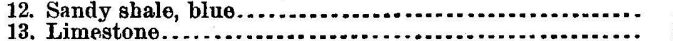

14. Sandstone, shaly ............................... 12

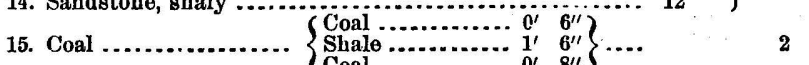

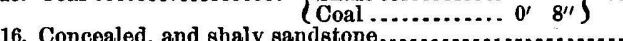

haly sandstone...........................

18. Coal, splint, Middle Kittanning .........................

18. Coal, splint, Middle Kittanning .........................

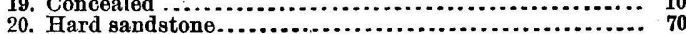

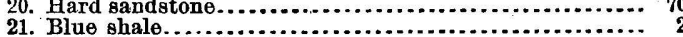

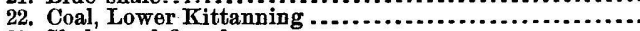

23. Shales and fire clay ....................................... 10

24. Sandy shale ............................................ 15

25. Black shales........................................ 115

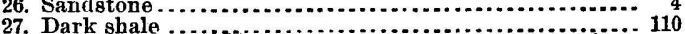

28. White sandstone, top of No. XiI:

Total.

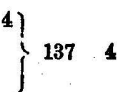

The place of the Upper Freeport coal here is determined with comparative certainty by the massive Mahoning sandstones, which come in above No. 1, and also by the occurrence of the Mahoning coal, with its characteristic structure, at 235 feet above the Peach Orchard bed, and 135 feet above where the horizon of the Upper Freeport has been placed.

No. 15 is very probably a "split" from the Middle Kittanning bed, No. 18, and should be regarded as a part of the latter.

The Lower Kittanning bed, No. 22, is given as reported from a bore hole at "Old" Peach Orchard, by Prof. Shumard, who examined the drillings at the time the boring was made, and the rest of the section Frg. 119.-Section near below this is from a deep boring made for gas, about chard, Ky. $\quad 3$ miles distant, the record of which was obtained from Mr. F. H. Oliphant, the civil engineer under whose superintendence the deep well was bored. 
[BULL. 65,

There has been much variance of opinion among geologists who have examined the Peach Orchard coal bed as to its horizon in the series, some placing it as far dow $\mathrm{n}$ in the column as the Clarion coal, but this section shows that it is either the Lower Freeport coal of the Pennsylvania column or else one that is probably a "split" from the $\because \because \quad \begin{aligned} & \text { latter, viz, the Winnifrede bed of the Kanawha series. } \\ & \text { Section near Warfield, Kentucky. - In the vicinity of } \\ & \text { Warfield, Kentucky, oplosite the line of Logan County, } \\ & \text { West Virginia, and } 60 \text { miles above the mouth of the Big } \\ & \text { Sandy, the following structure (Fig. 120) is obtained by } \\ & \text { combining the surface observations with the records of } \\ & \text { of the Warfield gas wells : }\end{aligned}$

Trarfield, Kentucky, on Tug Fork of Big Sandy River.

[Seo map, $\mathrm{V}$ b.]

1. Upper Freeport coal (not see(n).... Ft. in. Ft. in.

. Mlassive sandstont', and conctaled ............. $\left(\begin{array}{lll}\text { Coal } \\ \text { Samily shajes.... }\end{array}\right.$ Fire clay $\ldots \ldots .22^{\prime} 0^{\prime \prime}$

3. Coal, Wvimnifrode... $\left\{\begin{array}{lll}\text { Coal, splint...... } & 1^{\prime} & 2^{\prime \prime} \\ \text { Clay......... } & 0^{\prime} & 1^{\prime \prime}\end{array}\right.$

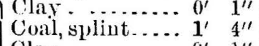
Clay .......... $0^{\prime} \quad \frac{1}{2}{ }^{\prime \prime}$

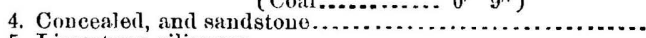

5. Limestome, siliceous.

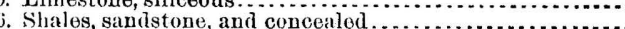

7. Coal eannel, Upper Kittanning -

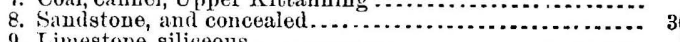

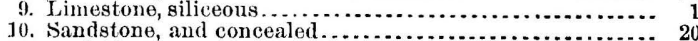

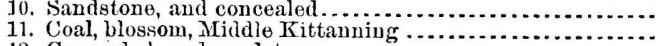

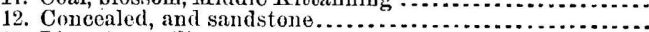

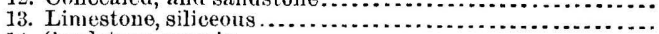

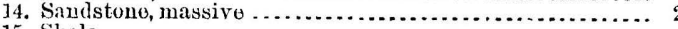

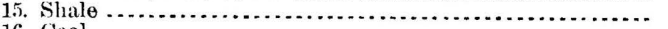

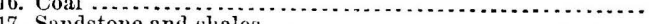

17. Simhtomeand shales .

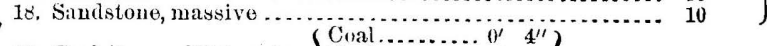

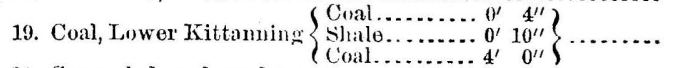

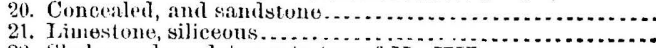

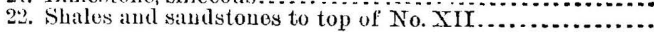

'lotal.

150

Some have supposed that No. 3 of this last section is identical with the Peach Orchard bed, but it seems to occupy a horizon a few feet below the latter, and I have

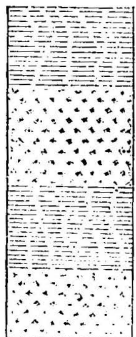
therefore referred it to the Winnifrede bed of the Kanawha column.

No. 19, which is locally known as the "Warfield" coal, is the same one as No. 22 of Section 119, and the representative of the Lower Kittanning bed.

The "siliceous" limestones, Nos. 13 and 21, may possibly represent the Campbell's Creeli and Ferriferous beds respectively. 
Section on Tug Fork of Big'Sandy River, Logan County, West Virginia.Near the mouth of Knox Creek, at the southern edge of Logan County,

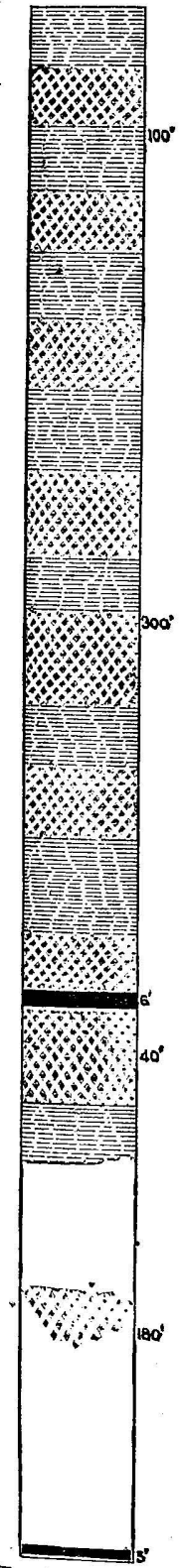

Fig. 121.-Section on Tug Fork of Big Sandy River, near. mouth of Knox Creek, southern edge of Logan County, W. Va.
50 miles by the river above Warfield, the following section (Fig. 121) was constructed on the West Virginia side of Tug River, by adding to the upper portion of the section there the part which has been removed by erosion:

Tug Fork of Big Sandy River, near mouth of Knox Creek, southern edge of Logan County, West Virginia.

[See map, W d.]

1. Upper Freeport coal (absent) .............................

2. Shales and sandstone.

Ft. $\quad$ Ft.

3. Coal, Lower Freeport.......................................

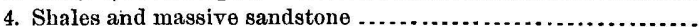

5. Coal, Lower Kittanning, large blossom ......................

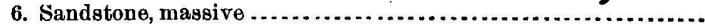

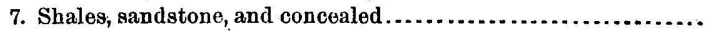

8. Coal, Eagle, large blossom

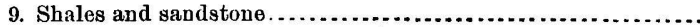

10. Coal, blossom, Little Eagle.

11. Concealed $-r^{-} \cdot$

12. Sandstone, flaggy.

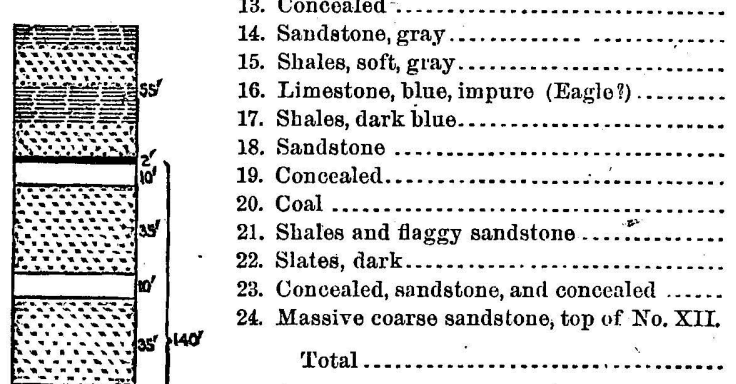

45

\section{CHARACTERISTIC HORIZONS.}

THE UPPER FREEPORT COAL.

As may be seen by thesections just given, a very important coal bed comes at the summit of the Lower Coal Measures column, and marks the latter off from the Barrens above. This coal, which was named the Upper Freeport coal by Rogers, has a very wide distribution in the Appalachian field and is the source of much valuable coal and coke. The coal is not entirely persistent, however, being frequently too thin to mine, and from large areas it is absent entirely, though its horizon in the measures can then still be determined, and generally without much difficulty. The bed is probably more regular and persistent in Pennsylvania than 
in either of the other two States (Ohio aud West Virginia), but even there it is not always found in workable condition, being thin or wanting in some portions of nearly every county where its outcrop extends,

One of the main features which characterizes this bed is its complex. ity, since it is always separated into two or more benches by divisions of slate. This complexity of structure is illustrated at the type locality (Section 66), and so far as the writer knows it is never entirely absent anywhere in the Appalachian field, whenever the bed is thick enough to mine. These parting slates vary in both number and thickness in different regions, so that there is nothing characteristic about them over the whole field, but yet in any particular district or coal basin their number and position in the bed are quite regular.

Another peculiarity of the coal is that it nearly always cokes well whenever attaining anything like its normal thickness and hence in several regions is locally known as the "coking vein." There are many districts where this bed will produce coke but little if any inferior to that of the Pittsburgh, in the famous Connellsville basin, and when the latter is exhausted the next source of supply to the Pittsburgh and Pennsylvania region generally must come largely from this horizon. Still another feature of this coal is its tenderness, and by this it can often be distinguished from the very hard Mahoning coal next above (which often rivals this bed in size), since as a rule the coal from the Upper Freeport horizon does not bear much handling without breaking up most of the lumps, although they often come out of the mine with large size. This is true of the bed everywhere in Pennsylvania and West Virginia (except in the south western part of the latter State, where it is often a splint coal), and Prof. Orton reports the same thing as characterizing it all over the Ohio field.

There is frequently a layer of impure cannel or highly bituminous slate in the roof of this coal, and in the Great Kanawha region a fine deposit of cannel coal occurs at this horizon. This is true of the Cannelton locality, but whether any of the cannel deposits on Coal River, south from the Kanawha, belong at this same geological level is as yet undetermined, since the latter bave not been sufficiently studied, though the flora would indicate that the Peytona deposit belongs at the horizon of the Upper Kittanning coal.

The several sections that have already been given (Nos. 50-121), indicate the structure of the Upper Freeport bed in many regions, but there remain others where it is equally important, and some of these will now be given.

Section at McCoy shaft, near Gallitzin, Cambria County, Pennsylvania.Some large coke plants have recently been put into operation on this bed along the line of the Pennsylvania Railroad and its branches on the summit of the Alleghany Mountains in Cambria and Cleartield 
Counties. At the McCoy shaft, near Gallitzin, the coal has the following structure, according to the superintendent's statement:

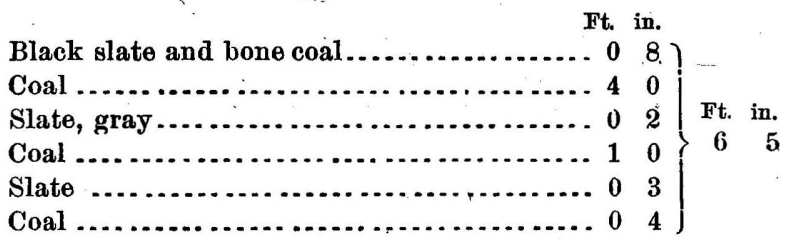

Section near eastern end of old Portage Railroad tunñel, at Gallitzin, Pennsylvania.-Near the eastern end of the old Portage Railroad tunnel, at Gallitzin, the coal is well exposed, and there shows as follows:

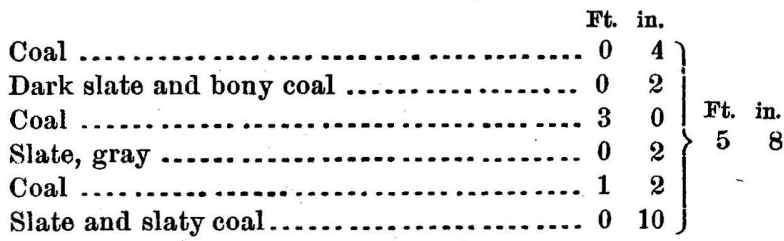

According to Messrs. Chance and Platt, this coal is but poorly represented in the present mining regions of Clearfield and Jefferson Counties, Pennsylvania, but it is possible, as already suggested in connection with section 88, that in some cases, at least, the Upper Freeport coal may have been erroneously referred to the horizon of the Lower Freeport.

Section at Mount Equity mine, Bedford County, Pennsylvania.-In the Broad Top field this coal is finely developed in Bedford County, where it is known as the "Kelly seam," and exhibits the following structure at the Mt. Equity mine, according to Stevenson, Report $\mathrm{T}^{2}$, Second Geological Survey of Pennsylvania, page 62:

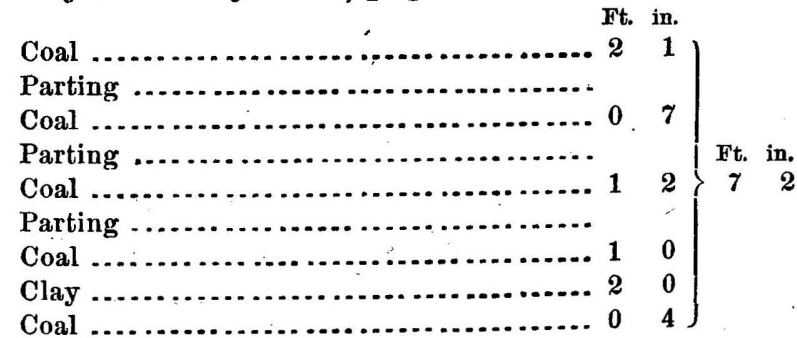

Although this bed is so well developed in Bedford County, jet when followed northward into Huntingdon, only 10 miles distant, it thins away to only 1 foot or even less.

Followed southward from Cambria County along the Alleghanies, this coal becomes quite thin and slaty.in Somerset, and where the bed enters Maryland near the northern end of the Georges Creek basin, it is only 3 to 4 feet thick and quite slaty, there being a layer of bony, worthless coal, 1 foot thick, just above the middle. 
This poor condition of the bed seems to be maintained southward along the Georges Creek basin to Piedmont (Section 92) and up the North Potomac (Section 93) to near its source (Section 94) before the coal becomes valuable again, since there the whole bed thickens up to 8 feet, and is extensively mined at Thomas, on the West Virginia Central Railroad, in spite of the fact that 2 feet of bony, worthless coal still remains near the center of the bed.

In the Ligonier basin of Westmoreland and Fayette Counties, Penn. sylvania, Prof. Stevenson reports this bed of inferior quality, being filled with knife edges of slate and containing too much sulphur for the manufacture of coke, though it often has a good thickness. This condition of affairs is continued southward along the Ligonier basin into Preston County, West Virginia, until we begin to approach the vicinity of Cheat River, when a great change takes place in the character of the coal, the sulphur and thin slates disappearing and the whole becoming a most valuable coking coal.

Section at Posten's bank, near Masontown, Preston County, West Vir. ginia.-Whe section at Mr. Posten's bank, 2 miles from Masontown, Preston County, shows the following structure:

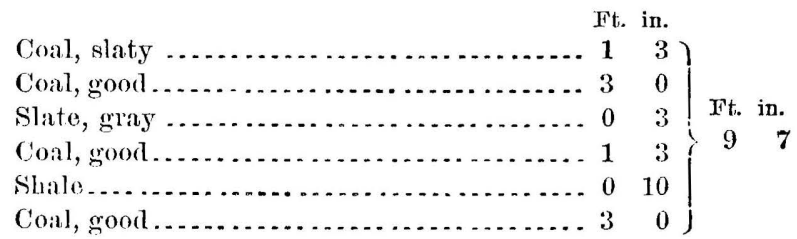

This is near the center of the basin, and the coal is there thicker than the average.

Section at Hartley's bank, near Masontown, Preston County, West Virginia.-The following from the side of the trough near Masontown, at Mr. Hartley's bank, will better represent the average thickness of this coal in the Preston basin :

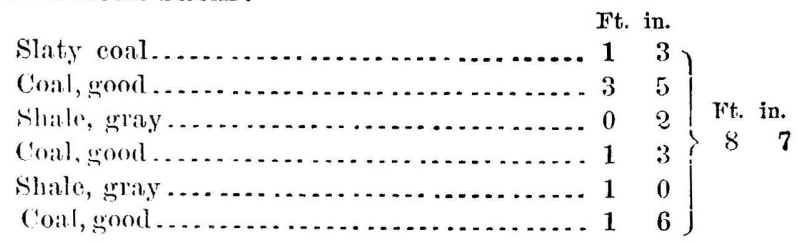

The first parting below the top is usually called the "little" slate, while the next one is known as the "big" slate.

This is the same coal that has long been coked for the manufacture of iron at Trondale, Preston County, and also near Austin, on the Baltimore and Ohio Railroad. At both of these localities the coal below the "big" slate is not taken out on account of the expense of mining the latter.

Sonthward from the Baltimore and Ohio Railroad this bed again splits up with numerous slate partings, and when it comes out to day- 
light, on the Valley River, at Philippi, the coal is 4 feet thick, but so slaty as to be almost valueless, and only 20 to 25 feet above the Lower Freeport coal.

Section at Wilson's mine, Roaring Creek, Randolph County, West Virginia.-Southward from Philippi it increases in thickness, and when we come to the eastern side of the Belington basin the bed has a total height of 10 to 15 feet, and is locally known as the Roaring Creek vein. Its structure there is shown by the following section at Mr. William Wilson's mine, in the northern edge of Randolph County, and about 1 mile east from the Valley River, at the mouth of Roaring Creek:

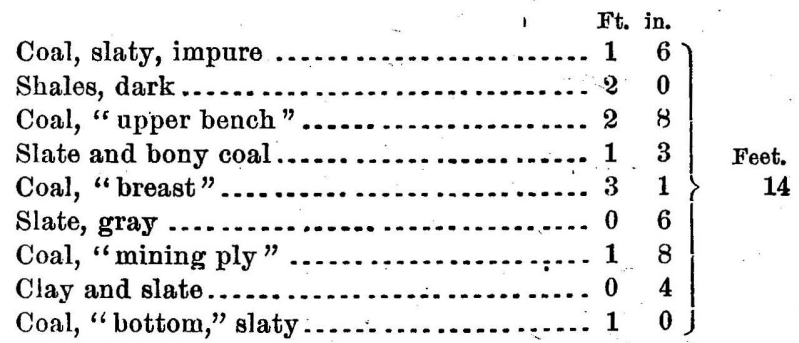

At some localities the "bottom" and "mining ply" benches form one layer of coal 3 to 4 feet thick, but as a rule the "bottom" portion is slaty and worthless, while the "mining ply" and the "breast" layers furnish very good fuel, the " upper bench" being frequently slaty and otherwise impure.

Followed still farther southward along the eastern side of the Appalachian field, through Randolph, Upshur, Lewis, Webster, Nicholas, Fayette, Kanawha, Lincoln, Oabell, and Wayne Counties, West Virginia, this coal bed presents the features shown in the sections given below.

Section on Stone Coal Run, Upshur County, West Virginia.-In Upshur County, 10 miles west from the Roaring Creek region, the Upper Freeport coal is exposed on Stone Coal Run, a tributary of the Big Sandy, which empties into the Buckhannon River. Here the following struct. ure is visible:

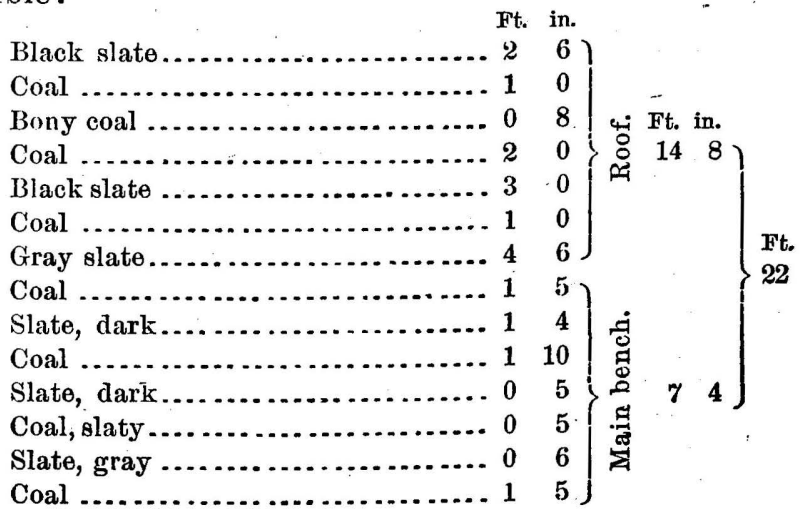


This is the locality of the celebrated "22-foot" coal bed of Upshur County. The detailed structure above given does, indeed, exhibit a bed of this enormous thickness, but it is so split up with slate as to be practically worthless.

Section on the Buckhannon River, Upshur County, West Virginia.-Still further west from this, on the main Buckhannon River, one-fourth of a mile above Grassy Run and $9 \frac{1}{2}$ miles from Buckhannon town, in a cut on the West Virginia and Pittsburgh Railroad, the following section is exhibited :

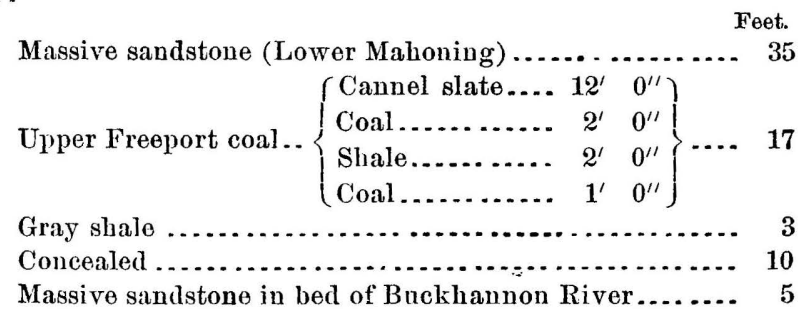

Here the coal has almost entirely disappeared in the g reat mass of canuel slate at the top, which, of course, contains a large quantity of bituminons matter.

Section at Lloyd Wamsley's bank, Upshur County, West Virginia.-About 10 miles south from the last locality we come to an area of this coal between the main Buckhannon River and its middle fork, where it has regained a structure more nearly normal, viz:

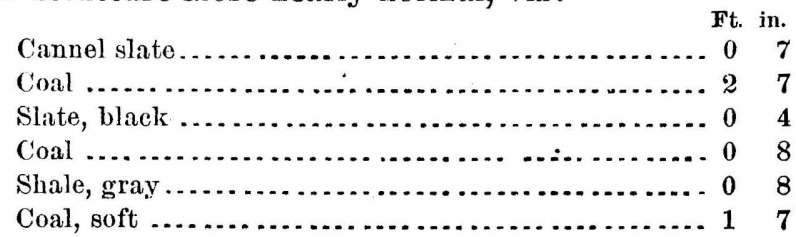

Mr. Bryan's baink, one half mile northwest, exhibits the following:

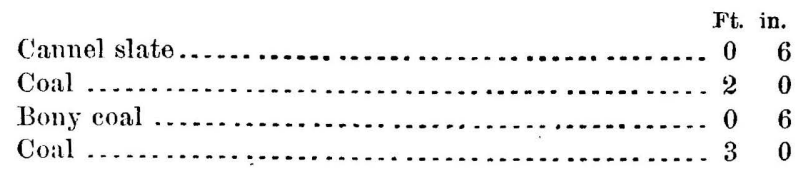

Section at Current's farm, Upshur County, West Virginia.-A few miles south of this, near the Randolph County line this coal passes into the air on the land of Mr. Current, where it exhibits the following:

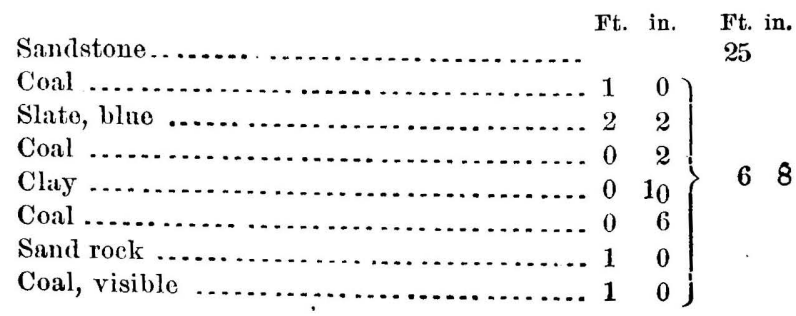


Section near Hacker's Valley P. O., Webster County, West Virginia.Southward from this, through the edge of Randolph, the coal has been eroded by the waters of the Buckhannon, but beyond Helvetia and the Florence Pass we come to an elevated plateau, from which the Buckhannon, Little Kanawha, and Holly (a tributary of the Elk) Rivers all take their rise, and here, in Webster County, 7 miles northeast from Hacker's Valley post-office, we catch an outlier of this coal with the following structure:

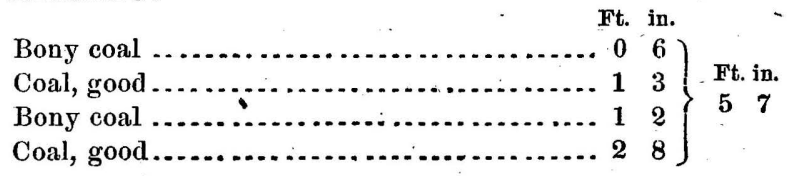

Section on the Little Kanawha River, Lewis County, West Virginia.About 10 miles northwest from this last locality the same coal exhibits the following structure (according to William S. Stevenson) in the hills along the Little Kanawha River, where the left branch of that stream cuts across the panhandle of Lewis County:

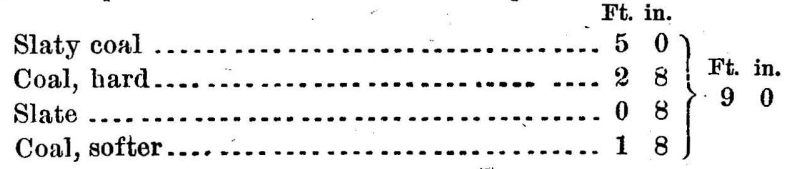

Section on the Holly River, Webster County, West Virginia.-In the summit of the hills near Anderson's mill, on the left branch of Holly River, Webster County, we find the Upper Freeport coal with the following structure on the land of Mr. Marcum Cougar:

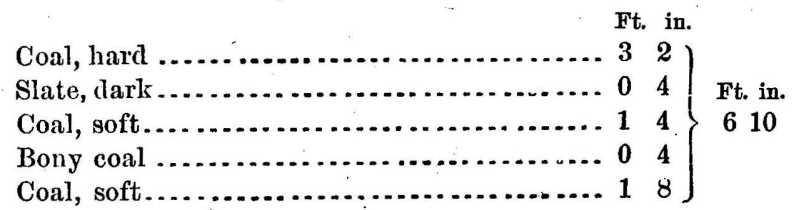

Section at Powell Mountain, Nicholas County, West Virginia.-To the sonthwest from this there are no more openings on this coal until we come to Powell Mountain, in Nicholas County, although a "7-foot" bed of coal is frequently "reported" in the hills where the Upper Freeport ought to be found. But in Powell Mountain it has been mined for a long time on the Weston and Gauley Bridge turupike, where it exhibits the following structure:

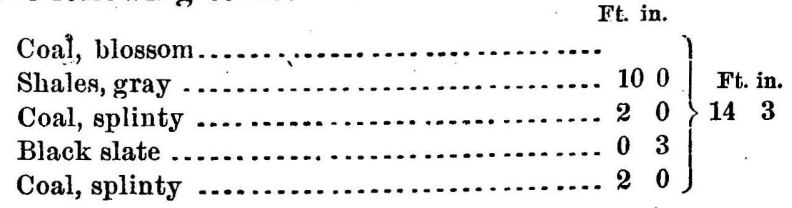

Here the character of the coal begins to change to the hard, splinty varicty which distinguishes the coals of the Kanawha Valley. 
Section on Stroud Creek, Nicholas County, West Virginia.-A few miles east from this, on the waters of Strond Creek, this bed shows the following section on the land of Dr. D. M. Lewis :

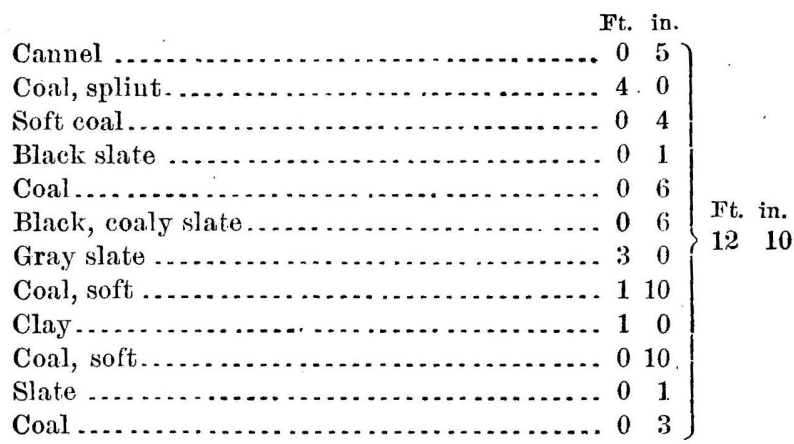

Sections on Mumble the peg Creek, Nicholas County, West Virginia.-On Mumble-the-peg Creek, half way between Powell Mountain and Nicholas Court-House, we find an opening in the Upper Freeport coal on the land of Mr. Herold, where it shows the following structure:

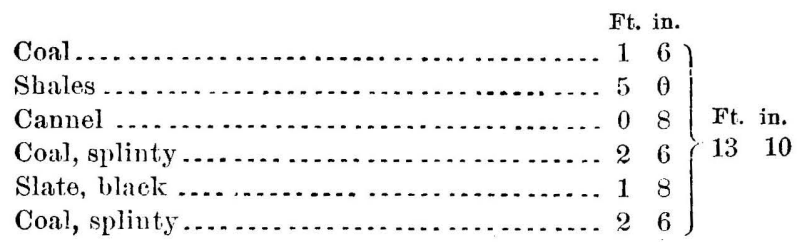

At another bank, 300 yards west from the last, the following is seen:

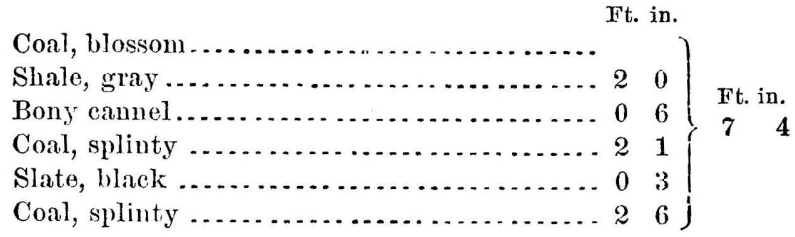

At this locality, as well as in Powell Momtain and on Strond Creek, a very good quality of splint coal is obtained from this bed.

From Nicholas Court-House on southwestward to the Great Kanawha River no openings have been examined along the crop of this coal, but at Cannelton, in Fayette Connty, we find it a valuable bed of cannel coal with a thickness of $1 \frac{1}{2}$ to 4 feet, while 2 to $2 \frac{1}{2}$ feet of bituminous coal rests immediately on the latter.

Two miles below Cannelton, at the mouth of Upper Creek, the bed thickens to 11 feet, but the layers of coal are so interstratified and diluted with slate and muddy sediment that the whole is worthless. A few miles farther down the Kanawha, at East Bank and Crown Hill, a portion of this great bed becomes the excellent splint coal, 3 to 4 feet thick, which is mined at those localities, but further down this river the bed again becomes impure and remains practically worthless from Coalburg on down until it disappears under the river at Charleston. 
West from the Kanawha we have no information about this coal until we reach the Guyandotte River in Cabell and Lincoln Counties, but it is possible that some of the Coal River cannel belongs at this horizon. Section on the Guyandotte River, Cabell County, West Virginia.-On the Guyandotte River the Upper Freeport coal rises above water level about two miles above the "Falls Dam." It is first opened and mined at the mouth of Stone Coal Run, where it exhibits the following structure:

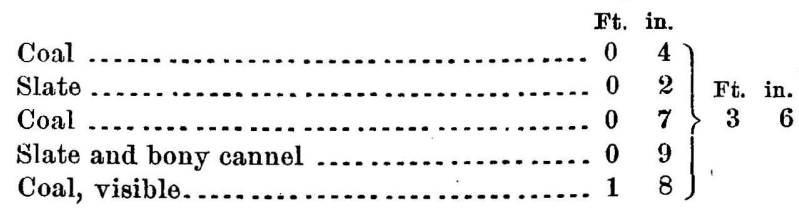

Another opening a short distance up the run gives the following:

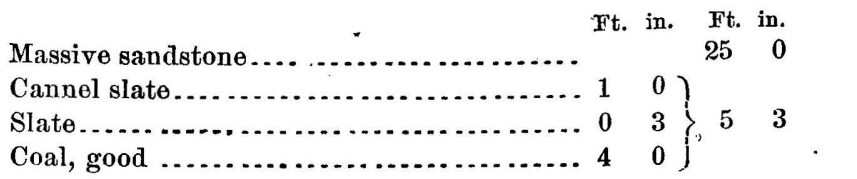

This latter section very probably belongs immediately on top of the first opening, since the interval between the two banks is concealed.

The coal is known in this region as the "big bed." On the Caldwell tract, opposite Camp Branch, this coal exhibits the following section in the bluff overlooking the Guyandotte:

Ft. in.

Sandstone, visible 100

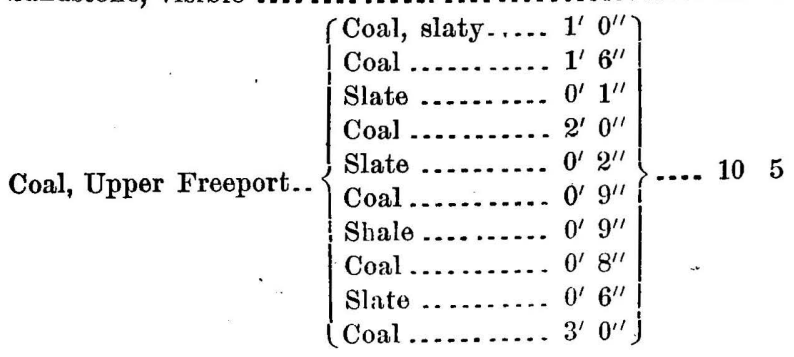

As will be perceived, the coal contains much slaty material and the layers of coal themselves are inclined to be bony and impure, approaching the type which this bed exhibits in the vicinity of the Kanawha Mining Company's plant on the Big Kanawha River.

Sections on Cove Creek, Wayne Oounty, WestVirginia.-As we pass from the Guyandotte in Lincoln County westward across the divide to the waters of Twelve Pole, a great change takes place in the Upper Freeport bed, and on Cove Creek we find it split into two portions with 30 feet of rock between, and the lower bench a fine quality of cannel coal 3 to 4 feet thick at some openings. 
At another locality the following is seen :

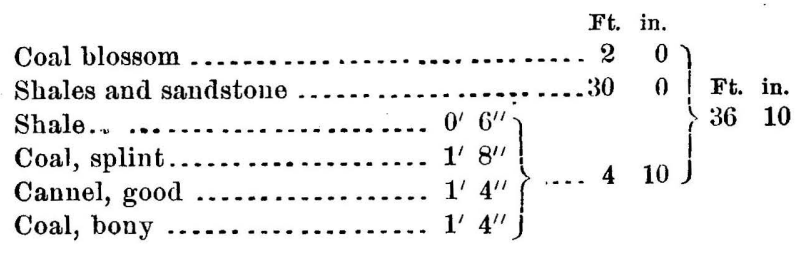

On the opposite side of Cove Creek we see:

Ft. in.

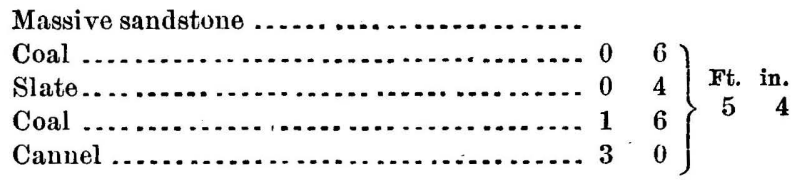

From this point a belt of cannel coal at the horizon of this bed extends in a general westerly direction nearly across Wayne County, being found on all of the main branches of Twelve Pole. It is possibly identical with the celebrated Moses Fork cannel and other cannel deposits in Kentucky. This belt of cannel varies much in width, but it is often 2 or 3 miles across, and while the bed is not entirely persistent, it is seldom less than 20 inches thick. It is quite pure and will compare favorably with the celebrated Kanawha cannel, which comes at the same geological horizon.

On the left branch of Twelve Pole, one-half mile above the mouth of Brush Creek, this cannel coal shows as follows :

Ft. in.

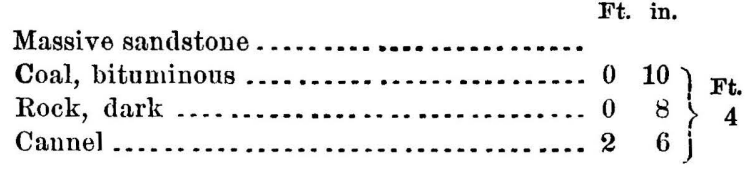

On Little Laurel, a branch of Hezekiah Creek (tributary of the left fork of Twelve Pole), the cannel exhibits the following:

Ft. in.

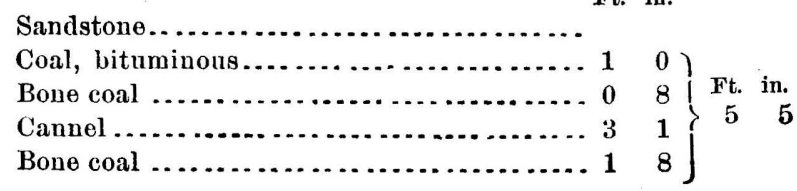


On Saw Pit branch of Cove Oreek the following section was measured:

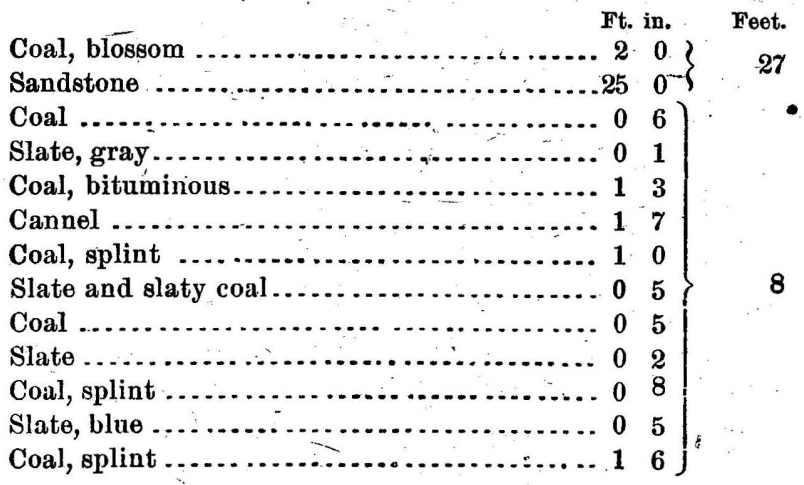

In Sugar Camp Hollow, a short distance above Jesse Queen's, the Upper Freeport cual exhibits the following structure:

Ft. in.

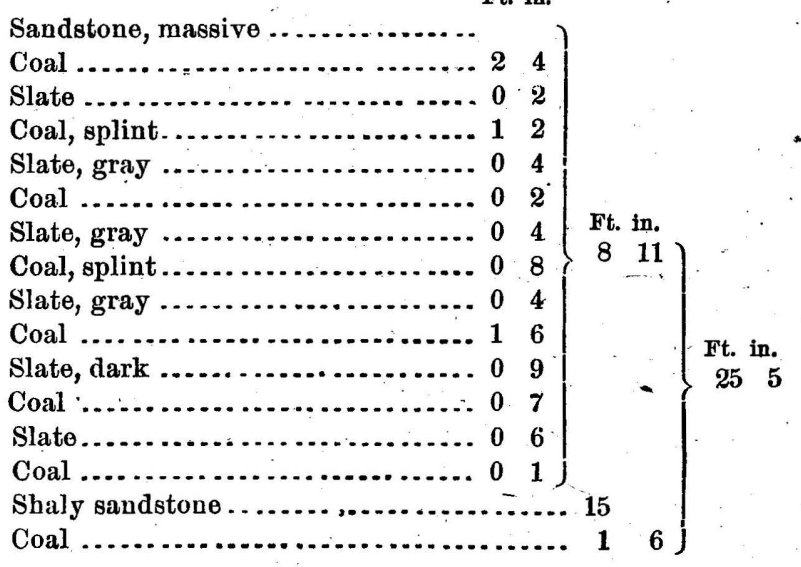

On Trough Creek, near James Rainey's, this coal exhibits the following:

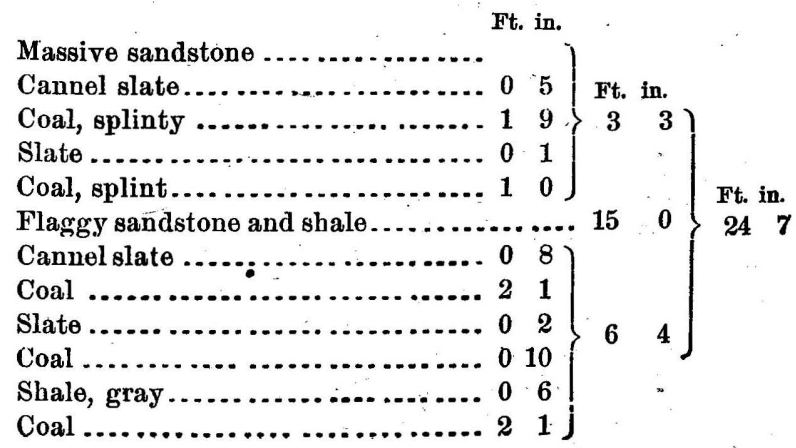


At Greene Porter's, on the right bank of Twelve Pole, the Upper Freeport bed shows the following:

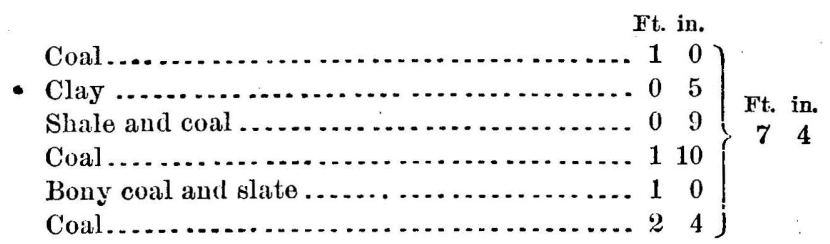

From this point on west to the Kentucky line on the Tug River nothing is known of the Upper Freeport coal, and at Warfield it seems to be absent from the section, but this may possibly be due to the fact that its horizon there overtops the summit of the hills.

In western Penusylvania there are large areas, especially in Beaver County, where this coal is either absent or else too thin to mine; so it enters Ohio not as a persistent bed, but occurring in patches, and this characteristic seems to remain with it there, from the Pennsylvania line entirely across the State to the Kentucky border at Ironton.

- Even along the Ohio River from the Pennsylvania line down to where this bed dips below the same, it is generally absent, and Prof. Orton thinks it is still absent in the Steubenville shafts, the coal mined there being the Lower Freeport bed, instead of the Upper Freeport as was formerly supposed.

In eastern Ohio it is known as bed No. 6 in the Ohio scheme of numbers, but in other portions of the State, as Prof. Orton has shown, it was often called No. 7. The following list of Ohio names for this bed will indicate regions in that State where the bed becomes prominent: "Big Vein" of Sălinesville, "Dell Roy," "Cambridge," "Alexander," "Bayley's Run," " Norris," " Happy Hollow," "Waterloo."

Section near Kenova, West Virginia.-After passing beneath the Ohio River above Steubenville, this bed never emerges from the same until withiu 2 miles of the Kentucky line, and if the Steubenville shaft coal be the Lower Freeport, then the Upper one is absent over a wide region along the Ohio River, for it appears to be absent in several borings, notably at Parkersburg and Pomeroy. It is reported from a boring at Huntington, however, as 10 feet thick, though where it comes up to the level of the Chesapeake and Ohio Railroad at the east end of the Big Sandy bridge, 10 miles below Huntington, the bed is worthless, as shown by the following structure there:

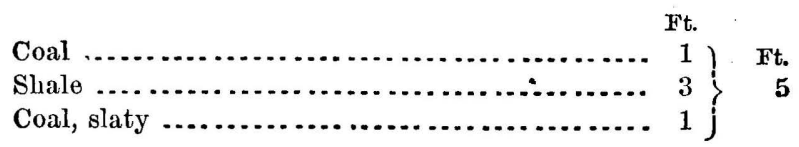


Section in Ritchie County, West Virginia.-Where this bed is brought to the surface on the Volcano anticlinal in Ritchie County, West Virginia, it has the following structure, according to Stevenson:

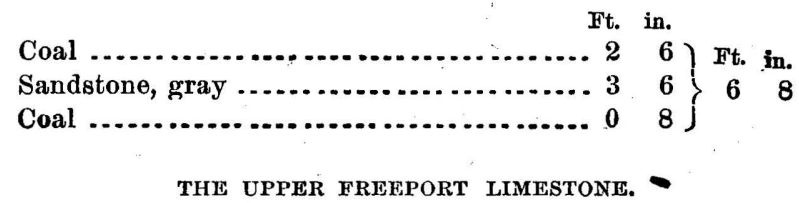

Below the coal just described, at an interval which varies from 0 to 40 feet, there comes a limestone which was named from the samelocality as the coal. It is quite generally distributed in Pennsylvania, northern West Virginia and Ohio, but in the southwestern part of West Virginia it appears to be absent, since it has never been reported from the region along the Big Kanawha and its tributaries, nor from the region between that and the Big Sandy.

The limestone is usually of a light gray color on fresh fracture, but some of the layers are always buffish when weathered, owing to included iron. Frequently the rock presents a brecciated aspect, as if made from the broken fragments of an older limestone.

Fossils are rare in this bed except a minute univalve which looks as if it might be of fresh water origin. Some lajers of this stratum generally contain a considerable amount of carbonate of magnesia, and occasionally enough to constitute it a good rock for the manufacture of hydraulic cement.

The thickness varies from 1 foot up to 30 feet as a maximum, though the average might be placed at 5 to 8 . It makes an excellent lime for fertilizing purposes, and is much sought after to enrich the barren soil lands above, though it is occasionally mined for use in blast furnaces, as on the Alleghany River between Freeport and Kittanning, where it is unusually thick.

In Ohio this bed has been given several names, as "Shawnee," "White," "Buchtel," etc. There, also, as in Pennsylvania and West Virginia, it occasionally becomes iron-bearing and some or all of its layers develop into iron ore, which is known in Ohio as the "Buchtel" ore, and in Pennsylvania as the "Summit" ore.

THE BOLIVAR FIRE CLAX.

When the Upper Freeport limestone is absent, or but slightly represented, there occasionally comes into the section at its horizon a bed of excellent fire clay, which from having long been mined near Bolivar, Westmoreland County, Pennsylvania, is generally known as the Bolivar clay. As there developed it shows a fine quality of non-plastic clay which is used in the manufacture of fire brick and gas retorts. It also occurs in several other regions of Westmoreland County, as well as in Fayette and other Pennsylvania counties. 
This clay has been reported as valnable at only two or three points in Ohio, viz, in Jefferson and Muskingum Counties, while in West Vir. ginia it is known to be valuable in only one region, viz, on Deckers Creek, in Preston and Monongalia Counties.

THE UPPER FREEPORT SANDSTONE.

As a rule the main portion of the interval between the Upper and Lower Freeport coals is occupied by sandy shales or thin flaggy layers of sandstone, separated by shales, but occasionally a bed of massive sandstone makes its appearance at this horizon and it has received the name of Upper Freeport Sandstone. It is quite prominent in some portions of Pennsylvania, but appears to be generally absent in Ohio. It is also conspicuous along the Great Kanawha and in all the region of West Virginia, south west from there, sometimes attaining a thickness of $7 \tilde{5}$ feet, while in Pennsylvania it is seldom more than 30 feet.

When this sandstone is not present as a massive rock there occasion. ally occurs a thin bed of coal in the interval between the Upper and Lower Freeport coals, and I have termed it

THE MIDDLE FREEPORT COAL.

This bed is shown in Section 66 at the typical Freeport locality, and as already stated in connection therewith, its presence in other sections may have led to some confusion in identifications. It is not a regular member of the series, however, and is probably never much thicker than at Freeport, viz, 2 feet.

The interval between the Upper and Lower Freeport coals varies greatly in thickness, runuing up sometimes to 80 and again thinning away to 20.odd feet, as shown in Section 65.

THE LOWER FREEPORT COAL.

This bed is quite as variable, or even more so than the Upper Freeport above. The rule is that whenever one of these beds has a fair development the other is poor or worthless, but in addition to this uncertainty, they are both frequently thin, or practically absent from the section at the same time, so that no one should look upon any of these coal beds as being continuously valuable over wide areas.

As shown in Section 66 at the type locality of this bed, it is even more complex in its structure than the Upper Freeport above, being split into two well defined layers separated by a stratum of clay and limestone. It is quite probable that this dividing layer may at times thicken up greatly as all other rocks do, and separate the two layers of coal by an interval of several feet, thus making two apparently distinct coal beds, but which should realiy be classed as members of one.

If Messrs. Chance and Platt are correct in the identifications of the Lower Freeport coal in Jefferson and Clearfield, there are large areas in both of these counties where this coal is quite valuable, since it is 4 
to 7 feet thick and of excellent quality, though it is always separated into two or three benches by partings of slate.

The upper portion of the Lower Freeport bed often has a tendency to become canuelly, as at Freeport, and some highly bituminous shale is frequently present at this horizon, even when the coal is absent.

Another very fine development of the Lower Freeport coal is in the vicinity of Fairmont, Clarion County, Pennsylvania, where according to Chance it is 5 to 7 feet thick without any partings, and furnishes an excellent quality of gas coal, as it does in the Reynoldsville region of Jefferson County.

In Ohio the reputation of the coal as a patchy deposit is fully sustained, since Prof. Orton says of it (Vol. V, p. 166, Ohio Geological Survey), "this is a seam the horizon of which can be followed throughout the entire field, but which becomes workable at comparatively few points."

In eastern Ohio it is called No. 5, but in Stark County and southwestwarl it is known as No. 6a, while the synonyms, "Whan" "Steubenville Shaft," "Roger," "Hamden Furnace," and "Hatcher" indicate localities where the bed becomes important.

If the "Steubenville Shaft" bed really represents this coal instead of the Upper Freeport, then there is quite a large field of it along the Ohio River, for it is found of good thickness in every boring as far south as Moundsville, West Virginia, where it underlies the Ohio by more than 600 ) teet.

Section near Philippi, Barbour County, West Virginia.-In Preston, Monongalia, Mineral, and Tucker Counties, West Virginia, this bed is quite thin and often absent entirely, so it is not mined till we go south into Barbour County, where it thickens up and in the vicinity of Philippi exhibits the following structure:

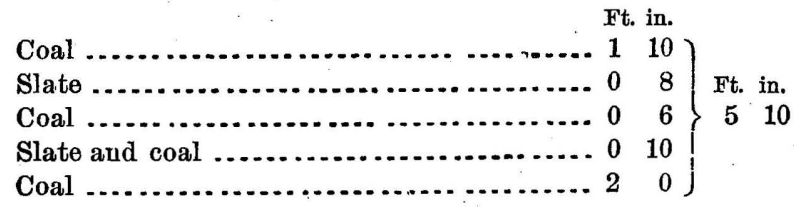

Nothing is known of the Lower Freeport from Philippi on southwestward along the eastern margin of the Appalachian field until the Great Kanawha River is reached, except in the Roaring Creek field, where it is only 2 feet thick and 25 feet below the upper bed.

But from the fact that this coal becomes one of the principal beds in the Kanawha region, and from there on southwestward into Kentucky, it is inferred that it is also a valuable bed at some points between Philippi and the Big Kanawha.

On this latter stream the Lower Freeport appears to be the parent of two valuable beds known respectively as the Coalburg and Winnifrede veins. The former certainly belongs to this horizon, and the latter Bull. $65-11$ 
probably does, though formerly I was iuclined to refer it to the horizon of the Upper Kittanning. The Lower Coal Measures thicken up so greatly in that region, however, and the intervals separating the Coal burg and Winifrede beds from the top of the series and from each other vary so much that it seems more probable they are both members of the complex Lower Freeport coal. The Coalburg and Winifrede beds. are themselves complex, being always separated into two or three benches by layers of very hard slate or bony coal locally known as "nigger head." They usually furnish the variety of coal known as "splint," and the Kanawha "splint" is highly prized as a general do. mestic fuel. These two beds are quite irregular in their thickness and one or both are often too thin to mine, but they appear to be much more regular and persistent southwest from the Kanawha than the Upper Freeport, since they furnish valuable coal clear across to the Big Sandy River, the celebrated Peach Orchard coal of Kentucky coming at the horizon of either the Coalburg or Winifrede bed, or both combined. This latter view is the more probable, since at the tunnel near the New Peach Orchard mine the coal is seen splitting up till it is scattered through more than 40 feet of rock material.

Section of bed at Coalburg, Kanawha County, West Virginia.-The following section shows the variations in the structure of the Coalburg bed at its typical locality :

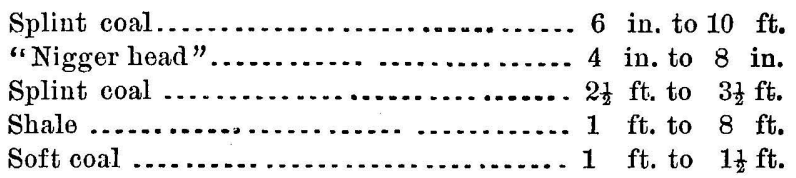

Section at Winifrede, Kanawha County, West Virginia.-The structure of the Winifrede coal at Winifrede is as follows:

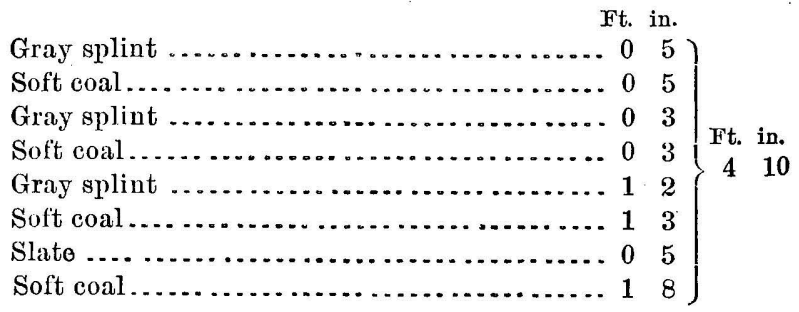

I do not know of any locality in the Kanawha Valley where both the Winifrede and Coalburg beds are mined one above the other in the same hill, for when one is good the other happens to be worthless, and this is so constantly true that, were it not for the fact that the Coal: burg bed is only 100 feet below the Kanawha black flint while the Win. ifrede seam is 175 to 200 feet below the same datum line, I would bo strongly inclined to believe that they were one and the same coal.

Section at mouth of Blaine Oreek, Lawrence County, Kentucky.-In de. scending the Big Sandy River the Lower Freeport sinks below water 
level at the mouth of Blaine Creek, 6 miles below Louisa, where it exhibits the following structure:

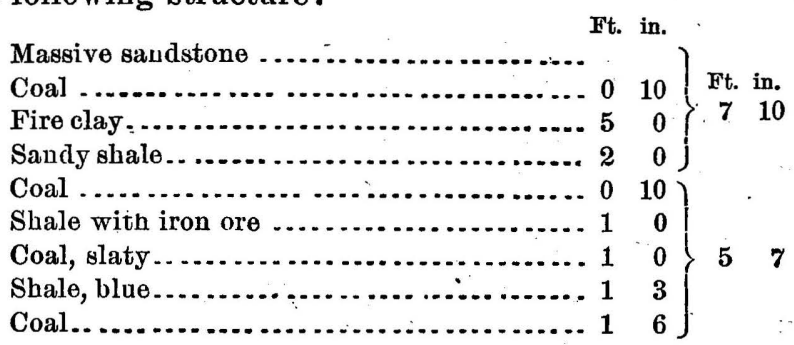

THE LOWER FREEPORT LIMESTONE.

The conditions preceding the spread of a great coal marsh seem to have been eminently fitted for the production of limestone deposits, especially in the Pennsylvania and Ohio regions, for, with few exceptions, a limestone is found close under every coal bed, and this is true. of the Lower Freeport horizon. This limestone very much resembles the one under the Upper Freeport coal, except that it is usually thinner and more earthy. It also contains the same univalve fossil, and no others, so far as the writer is aware, thus showing that it too is a freshwater deposit. It contains a considerable quantity of carbonate of magnesia and occasionally, as at the locality of Section 103, furnishes material for the manufacture of hydraulic cement.

Considerable iron ore is also found at this horizon, and the limestone is generally of a buffish cast from the disseminated iron. From this fact it and the Upper Freeport limestone above are generally called the "buff" limestones in southern Ohio.

In West Virginia this limestone has not been recognized anywhere in the northern part of the State, and it iswcertainly absent entirely along the Great Kanawha. An impure limestone is sometimes found in connection with the Peach Orchard coal of Kentucky, which is possibly identical with the Lower Freeport.

THE LOWER FREEPORT SANDSTONE.

The next lower stratum that has a general distribution over the Appalachian field is known as the Lower Freeport sandstone. Section 66 shows the thickness and structure of this sandstone at its typical locality, and there it is seen to be double, with a coal embedded in its lower portion, the whole being 62 feet thick. That the 15 feet of sandstone under the coal at Freeport belongs properly with the main sandstone above is known from the fact that at one locality the coal is seen disappearing entirely and then the two beds of sandstone unite into one solid mass.

This rock is always of a grayish white color, generally quite hard, often containing pebbles as well as much feldspar, which decomposing permits the rock to disintegrate readily and weather into fantastic 
shapes. It is more persistent as a massive rock than the Mahoning even, but unlike the latter it is seldom used for building purposes; This is owing to its hardness, coupled with the fact that it will not. stand the weather well, and also it is often so gnarly and twisted in its bedding that it will not split evenly.

This sandstone is never less than 30 feet thick in the Pennsylvania region, and it frequently rises to 75 and even 100 feet in some localities, making a bold cliff or bluff wherever its outcrop is above drainage, and thus becoming a conspicuous feature in the topography of the Lower Coal Measures.

Throughout a large portion of Beaver County, Pennsylvania, this sandstone is 75 to 80 feet thick, and near its center is a very hard calcareo-siliceons layer 2 or 3 feet thick, which may possibly represent the Johnstown Cement limestone in other portions of the State.

The sandstone maintains about the same thickness throughout eastern Ohio as in Bearer County, and continues on around to southern Ohio with a thickness of 30 to 50 feet.

It euters West Virginia from Pennsylvania as a very massive bed, 50 to 75 feet thick in Monongalia and Preston Counties, while in Tucker, Taylor, Barbour, and Randolph, it is still thicker and more pebbly eren than the Pottsville conglomerate. Southwestward through Randolph, Webster, Braxton, and Clay, this sandstone keeps on increasing in thickness, and when the Big Kanawha is reached it has swelled out in a wonderful manner, becoming 250 to 300 feet thick, and remaining the same across to the Big Sandy, often crowning the hills and ridges with cliffs weathered into turreted and chimney-shaped forms. When attaining this immense thickness it often consists of three or four sandstones, with shales and two or three coal beds interstratified.

This rock has produced a small quantity of oil at Fairview, Marion County, West Virginia, and is generally known as the "gas sand," in the drillers' parlance, since it often produces considerable quantities of natural gas.

THE UPPER KITTANNING COAL.

Throughout several counties of Pennsylvania a third bed of good coal occurs at 80 to 120 feet below the top of the series, and to this Messrs. Chance, Platt, and other Pennsylvania geologists, have given the name Upper Kittanniug, though the bed in question is not workable at Kittanning or anywhere near that town, as may be seen from Sections 60-66 along the Alleghany River, since it is thin and unimportant in that region. The Messrs. Platt at one time identified this coal with the Lower Freeport bed in Cambria, Clearfield, and Jefferson Counties, calling the coal which is now termed Lower Freeport there the Middle Freeport, and it is barely possible that this first arrangement of the stratigraphical order was the correct one in many regions, since, as already shown (see 66), there is a Middle Freeport coal eren. 
at Freeport, and in addition the Lower Freeport bed is itself so complex that either half of it might at any time separate from the other and both become independent beds.

But however the questions suggested may turn out, the fact remains that at many localities in Pennsylvania, at least, there are three distinct coal beds between the Ferriferous limestone and the Lower Freeport coal, as shown in Sections 64, 65, and 66.

Westward in Ohio, however, the Upper Kittanning coal appears to be either wanting entirely in most cases or else coalesced with the Middle Kittanning bed, since Prof. Orton finds no place for it as a regnlar member of the Ohio series, but puts it down as a synonym for the Lower Freeport seam. (See Vol. V, p. 126, Ohio Survey.)

In West Virginia the Upper Kittanning bed first appears in the sections along the Tygart's Valley River (96 and 97), where it is 2 to $3 \frac{1}{2}$ feet thick, and a rather fair coal ; but it appears to be absent entirely in the Newburg shalt, Preston County, unless it is combined with the Middle Kittanning there, while in the North Potomac basin near Davis it is represented by a mere streak. In the Kanawha field two or three thin beds come at this horizon, and one of them is frequently cannel, and the same horizon can be recognized on the Guyandotte River, in Wyoming County (Section 117).

Chance says that it is the main cannel horizon in Pennsylvania, the New Bethlehem, North Washington, and Murrinsville cannel deposits coming at this horizon. If the Darlington cannel, of Beaver Uounty, comes at this same horizon, then the interval separating the Upper and Middle Kittanning beds has there thinned entirely away, and thus bronght the two into direct contact. This might well be, since the Darlington cannel rests directly on 2 feet of bituminous coal, below which, through a shale interval of 30 feet, comes the undoubted Lower Kittanning coal, underlaid by its great bed of fire clay. This would account for the absence of the coal in Ohio, if it really does unite with the Middle Kittanning before crossing the Pennsylvania-Ohio line.

This bed appears to attain its greatest importance in Pennsylvania, along the eastern border of the coal field through the counties of Jefferson, Clearfield, Cambria, and Somerset, where it has been fully described by Messrs. Platt and Chance. The general sections already given show the horizon and structure of this bed at numerous points, so that no further description of it is necessary.

THE JORNSTOWN (CEMENT) LIMESTONE.

Lying only 2 to 5 feet below the coal just described, there occurs, over a wile region in Pennsylvania, a bed of magnesian limestone, which Mr. Franklin Platt named the Johnstown Cement, from its occurrence at the city of Johnstown, Cambria County. It is almost an exact counterpart of the Lower Freeport limestone of the connties farther west in physical aspect, chemical composition, fossils, and everything else, and 
this is one of the facts which, taken in connection with the entire ab. sence of this limestone in the western tier of counties and in Ohio, has sometimes led to the suspicion that possibly the Johnstown Cement and the Lower Freeport limestone of Butler and Beaver Counties are identical. Still there are other facts of stratigraphy which appear to forbid such an hypothesis, and hence, until it can be shown otherwise by more positive demonstration, we must accept the stratigraphical horizon given the Johnstown Cement first by Messrs. Platt, whose labors moved it up from the horizon of the Ferriferous limestone, to which the First Geological Survey of Pennsylvania had erroneousiy assigned it. The stratum ranges in thickness from 1 to 8 feet, and when it is $\mathbf{5}$ feet or more some of the layers often make good lime for agricultural or other purposes; but when the bed is only 1 to 3 feet thick it is usually too impure to slake well. This stratum has not been recognized at any point within West Virginia with which the writer is familiar, and it thus appears to be generally absent from the series in that State.

THE MIDDLE IITTANNING COAL.

Whatever uncertainty may exist concerning the exact horizon of the coal which has just been described under the name of Upper Kittan. ning, there is none with reference to the next lower bed, for it is such a constant member of the series that its relations to the other rocks are seen in nearly every section. This bed was formerly called the Upper Kittanning, until Messrs. Platt and Chance discovered that the coal last described was a member of the Kittanning group, and then the coal in question was lowered to the name of Middle Kittanning.

In the vicinity of Kittaming (Section 63), and along the Alleghany River below (Sections 64,65 , and 66 ), this bed is thin and unimportant, but west from this it thickens up and is the most important seam in Butler, Lawrence, and Beaver Counties, the coal being quite pure and highly esteemed for gas, steam, and domestic purposes, though it seldom exceeds 4 feet in thickuess, and is often much less. This is the famous "Clinton," "Rock Point," and "Hog Hollow" coal along the Beaver River. It is always divided by one or more thin slate partings, one of which is usually near the bottom.

Eastward from Butler County, through Armstrong, Clarion, Jefferson, and Clearfield, this bed, according to Platt and Chance, declines much in thickness and value, so that it is seldom mined, except occasionally for domestic purposes.

Still farther eastward, however, in the Broad Top coal field of Huntingdon and Bedford Counties, it thickens up and is apparently represented by the "Barnet" coal of that region.

Sonthward from Pennsylvania, in Maryland and northern West Virginia, this coal is sometimes thick enongh to mine, though seldom exceeding $2 \frac{1}{2}$ to 3 feet. At the southern end of the North Potomac 
coal basin it practically unites with the Lower Kittanning below, and is mined with the latter where that bed is opened near Thomas; but at the Davis mine, further south, the parting slates have thickened up to 20 feet and separated it from the Lower Kittanning again.

Section at Newburg, Preston County, West Virginia.-In the deep shaft at Newburg, Preston County, West Virginia, this coal has the following structure and relations to other beds :

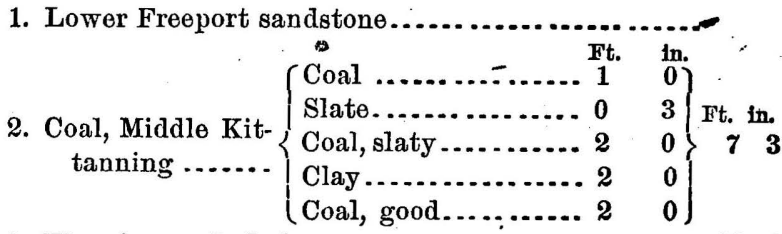

3. Fire clay and shales......................... 150

4. Coal, Lower Kittanning, with several partings.... 95

Here it is possible that both the Upper and Middle Kittanning beds are represented in No. 2, and they are only 15 feet above the Lower Kittanning coal.

In the Great Kanawha field, this bed, although only 3 to 4 feet thick, is very pure and valuable, being known there under the names of "Cedar Grove," "Trimble," "Arno," and others.

In the Wyoming County section (117) two beds are often found at this horizon, separated by 20 feet of shales, but the lower one appears to be the main coal. The same thing is seen in the Peach Orchard section (119), where the lower one is a "splint" coal, thin, but of excellent quality.

In Ohio this coal becomes the most important bed of all the coals in that State, according to Prof. Orton, since it is almost constantly workable from where it enters Columbiana County on the east to where it leaves the State near Irouton at the southwest. The numerous names it has received in Ohio will serve to illustrate its importance in the mining industry there, of which the following is a partial list: "No. 4, in Ohio and Yellow Creek Valleys at the east; "No.6," in Stark County and southwestward; " Hammondsville Strip Vein," "Onasburg," "Pike Run," "Dennison," "Coshocton," "Upper Zanesville," "Upper New Lexington," "Nelsonville," "Straitsville," "Great Vein" of the Hocking Valley, "Carbondale," " Mineral City," " Upper Zaleski," "Washington Furnace," "Sheridan," etc.

The tracing of this bed through Ohio, and its identification at many points where it had formerly been confused with other beds, is due largely to the labors of Prof. Orton, the present efficient director of the Ohio Geological Survey. The structure of the coal where it attains a considerable thickness, as in the Hocking Valley, is always quite complex, there being several parting slates, as may be seen from Sectious 105 and 106. 
Section in Hocking Valley, Ohio.-The following, from Vol. V, Ohio Geology, will serve to illustrate the general structure of this bed when at its maximum development:

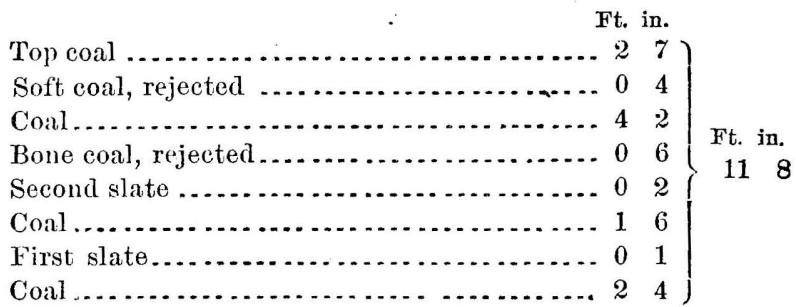

Section at New Straitsville, Perry County.-The following is the structure at New Straitsville, p. 954, loc. cit.:

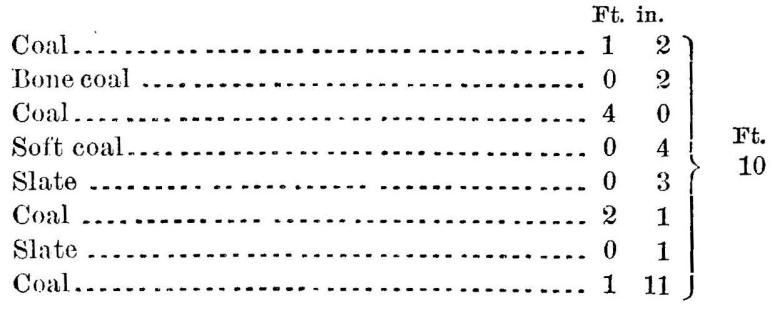

According to Orton this bed changes in character from a good coking coal in eastern Ohio to an open-burning one from New Lexington sonthwestward. The realer will find the coal fully described in Vol. V, Ohio Creology.

The interval separating the Middle Kittanning coal from the Lower Kittanning bed varies greatly both in thickness and composition in the different regions of the Appalachian field. In western Penusylvania and eastern Ohio the interval is usually only 20 to 30 feet and generally ocenpied with dark slates or shales holding iron nodules, and it seldom surpasses 40 feet anywhere in Peunsylvania, while in northern West Virginia it locally thius away to an insignificant parting, but to the southwestward in the Great Kanawha region, and from there across to the Big Sandy, it often swells up to 100 feet and oceasionally attains a thickness of 165 feet (Section 115), with some massive sandstone at several horizons. In southwestern Ohio a massive sandstone 30 to 40 feet thick often occupies the interval to the exclusion of shales.

In the Great Kanawha region a siliceous limestone makes its appearance in this interval and seems to have quite a wide distribution in that region and southwestward to the Big Sandy. It is well exposed near the mouth of Camplell's Creek, and I have designated it the Campbell's Creek linestone from that locality. This stratum seems to be present even in northern West Virginia, since in Sections 95 and 96, at Moatsville and Valley Falls, respectively, a bed of siliceous limestone occurs 20 feet above the Lower Kittanning coal.

Along the T'ug Fork of Big Sandy there are siliceous limestones at 
several horizons above the Campbell's Creek bed, as shown in Section 119 , there being two and sometimes three within the horizon of the Lower Freeport sandstone, so that these must not be confounded with the one in question.

The bottom layers of this shale interval immediately above the Lower Kittaming coal are nearly always filled with fossil plants. They occur in great variety and abundance wherever the rock material in the roof of the underlying coal is a shale, and this is the horizon par excellence for the collector of plants from the Lower Coal Measures.

These beds have been thoroughly explored at only one locality in the Appalachian field, viz, Cannelton, Beaver County, Pennsylvania, where Mr. I. F. Mansfield has collected systematically for Prof. Lesquereux during several years, the results of which are recorded in Report $\mathrm{P}$, Vols. $I$ and II, Second Geological Survey of Pennsylvania. The list includes a large number of species, several of which are peculiar to that locality.

THE LOWER KITTANNING COAL.

The next lower bed of this series, though formerly named simply the Kittanning coal by Rogers, is now called the Lower Kittanning. Although seldom attaining any unusual thickness, it is probably the most persistent bed in the entire Appalachian field, and has a workable thickness over a larger area than any other. In Pennsylvania it furnishes from 3 to 4 feet of valuable fuel over large areas in every comnty where its outcrop is due. Of course, like all other coals, it thins down locally and becomes worthless over considerable areas, but the barren patches on the horizon of the Lower Kittanning bed are fewer and smaller than those at the horizon of any other coal in the entire Lower Coal Measures. If the Middle Kittanning is the more important coal in Ohio, the Lower surpasses it in Pennsylvania and West Virginia, so that the difference in favor of the former in Ohio is much more than offset in the latter two States. This coal is also a composite seam, and when it acquires considerable thickness is often split into several divisions by separating slates. In the Pennsylvania field these slates are usually mere knife edges, and add but little to the total thickness of the bed, except in the eastern portion of the field, where in Clear. field, Bedford, and Huntingdon it often has a layer of impure fire clay or gray shale separating the bottom member from the middle one.

The "Fulton vein" of the Broad Top field appears to be identical with this coal, though the writer was formerly inclined to regard it as identical with the Clarion (see $T^{3}$, Second Geological Survey of Pennsylvania), and bed "A" of the Tipton Run series is probably the same.

The "Bloss vein" of Tioga County seems to be referable to this same horizon both with reference to structure and its position in the column of rockis (Sections 50 and 51).

In the Georges Creek field of Maryland this is often known as the "6-foot" bed, and its structure there is given in Section 92. From Elk 
Garden southward along the North Potomac to where this bed passés under drainage level, near Gorman, it is so badly split up with slate as to be rather valueless, but where it emerges to daylight again on the other side of the Cheat-Potomac divide, near Thomas, it has become a splendid vein nearly 11 feet thick, as shown in Section 94, from which 6 feet of excellent coal is mined without taking out the bottom member. As already stated, the bed attains its great thickness in this region by the thinning away of the shales which usually separate the Middle and Lower Kittanning beds, thus permitting the two practically to unite into one. The coal from it here is prized for smithing purposes quite as highly as the celebrated Blossburg bed, with which it appears to be identical. It has also been successfully coked in this Tucker County field, since it is nearly always a good coking coal everywhere.

Section at Newburg, Preston County, West Virginia.-In the deep shaft at Newburg, Preston County, West Virginia, the Lower Kittanning has the following structure:

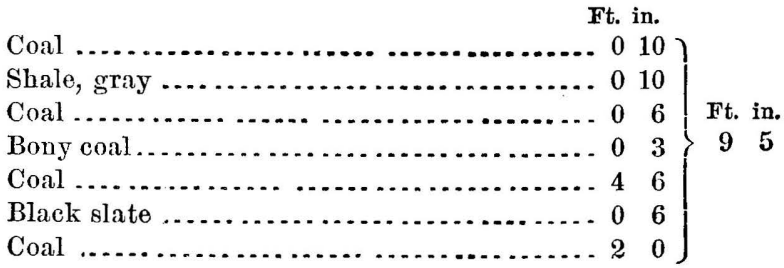

Sections 95 and 96 show the structure of this bed where it is brought to the surface by the Chestnut Ridge anticlinal, on the Tygart's Valley River, below Grafton, West Virginia, and, as will be seen, it is there about 5 feet thick.

On the Great Kanawha River, above Charleston, this is one of the principal coal beds, and has long been known there as the Campbell's Creek rein. At this locality on Campbell's Creek the coal is 4 to 6 feet thick with only two parting slates, but in passing southward up the Kana wha new partings come in and the old ones thicken up until the bed, with its included rock partings, swells ont to a thickness of nearly 50 feet, and two of the members are mined independently, the upper one being known as the Peerless bed and the lower one as the Blacksburg. The upper member never exceeds 3 feet, and is usually about 20 feet above the Blacksburg member, which is often 4 to 5 feet thick and is the "Coal Valley gas vein." On the Mount Carbon property, 25 miles sonth from Campbell's Creek, the 20 feet of shales which usually separate the Peerless and Blacksburg members of the Lower Kittanning coal thin away to a few inches locally, and both are taken out of the same drift. This is also the condition of affairs at the famous Anstead mines of the Hawk's Nest Coal Company on top of Gauley Mountain. At the head of Cabin Creek, a tributary from the south bank of the Big Kanawha, the Peerless and upper half of the Blacksburg member come completely together, forming a bed of excellent gas coal 5.2 feet thick. 
In Wyoming County, West Virginia, this coal, which is locally cailed the "Cook vein," has a good development, the whole seam with its parting slates being about 25 feet thick, as may be seen from Section 117, but the main portion of the bed is about 7 to 8 feet thick, separated into three layers by slate partings of 4 to 6 inches thick.

This coal rises above the level of the Tug Fork of Big Sandy about 3 miles below Warfield and 30 above Louisa. It has been mined to some extent for local use at Warfield, and is known in that region as the "Warfield coal." Its structure there is given by Section 119. Above Warfield it dips down under the stream and does not come up again for about 10 miles, or some distance above the mouth of Pigeon Oreek, but from there on up Tug River it is constantly accessible for about 40 miles, until the southward rise of the rocks throws the coal above the tops of the hills near the mouth of Ben Creek, 95 miles above the mouth of Tug. Along this line the coal is seldom less than 3 feet thick and frequently 4 to 5 feet, with only one slate parting 3 to 5 inches thick. At the mouth of Lick Oreek and 60 miles from Louisa this coal is 100 feet above the river, and reported 6 to 7 feet thick, with only one thin slate near the center.

In Ohio the Lower Kittanning coal is almost as persistent as in Pennsylvania, rarely being absent entirely from the section, and generally having a thickness of 3 feet, with a maximum of 5 .

In the deep oil-borings across southwest Pennsylvania and northern West Virginia this coal is quite persistent, being frequently reported at a depth of 1,500 to 1,800 feet beneath the surface.

The following list of names has been given it in Ohio : Coal No. 3 in Ohio Valley and along Yellow Creek, No. 4 at Leetonia, No. 5 in Stark County and southwestward; also "Creek vein," "Potter's vein," "Leetonia," "Mineral Point," "Lower New Lexington," "Newcastle," etc. This coal is often neglected in Ohio even when it has a thickness of $2 \frac{1}{2}$ to 3 feet, because of the great development of the Middle Kittanning coal only a few feet above. Both of these beds have now, through the labors of Newberry, Orton, Roy, and others, been traced from the Pennsylvania line clear across Ohio to where they pass into Kentucky at Ironton, and have been so well described by Orton in Vol. V, Ohio Geology, that it is unnecessary for the writer to dwell on them longer.

THE KITTANNING FIRE CLAY.

Lying directly under the last described coal there comes in many regions a great bed of splendid fire clay which often overshadows the coal in value, since many millions of dollars are invested in manufactnring the several lines of articles which can be made from this clay. The bed has been named from Kittanning, where it is minerl, and here as well as at many localities in Ohio the clay does not all immediately underlie the coal, but some of it is found a few feet lower and nearly on top of the Ferriferous limestone. 
Eastward from the Alleghany River this clay does not appear to be very important, but westward from that point it is generally present, and attains its maximum development along the Beaver, and westward from there down the Ohio; the famous potteries at New Brighton, Roch. ester, East Liverpool, New Cumberland, and other points in these valleys all deriving their clay from this horizon.

In the Beaver County region the thickness is generally about 8 to 10 feet, but occasionally runs up to 15 and down to 5 . It often consists of two portions, an upper "soft" clay and a lower "hard" clay, the latter being used in the manufacture of fire brick, etc. In western Penusvlvania and eastern Ohio this clay bed is often a very valuable element in settling questions of stratigraphy which would otherwise be extremely difficult of solution; in fact it is valuable for this purpose clear across the Ohio coal field, since, according to Orton, although not entirely persistent, yet it furnishes valuable clay mines in every county of its outcrop from the Penusylvania line across to the Kentucky border.

In West Virginia (except along the Upper Ohio River) the deposit is seldom of value, being too siliceous, and it has been developed in only one region, viz, uear the locality of Section 97, at Nuzum's, on the Tygart's Valley River. Here along the crown of the Chestnut Ridge anticlinal the coal above locally disappears, and then a valuable bed of hard clay replaces it, but when the coal comes in again the clay disappears, just as it often does in Ohio, when the hard flinty clay is present. The Glade Fire Brick Works at Nuzums manufacture a good fire brick from this bed.

THE hITTANAING SANDSTONE.

The interval between the Lower Kittanning coal and the Ferriferous limestone varies greatly in thickness, sometimes only the clay bed just described interveuing, and again the interval thickens up to 50 to 75 feet or even more. Whenever the interval attains anything like these last figures we generally find a massive sandstone between the coal and the limestone, and to this has been given the name Kittanning. It sometimes, as on Buffalo Creek, Butler County, Pennsylvania, develops into a great cliff rock of massive and eveu pebbly sandstone, cutting ont the underlying limestone (Ferriferous). It often furnishes good quarry stone, and a rock occupying this horizon in the series has been quarried and used in building the Government lock and dam near Coal Valley, on the Great Kanawha River. In this region the interval between the Lower Kittanning coal and the Ferriferous limestone thickens up to 150 feet, and a local bed of coal, the Brownstown, comes into the series about half way in the interval. In Wyoming Connty and westward from there the Kittaming sandstone thickens to 100 feet, as seen in Section 117.

TIIE BUIRSTONE IRON ORE.

Resting immediately on top of the Ferriferous limestone there occurs over a very wide area a deposit of iron ore. In Pennsylvania it is often 
underlaid with cherty material, and hence long ago received the name of "Buhrstone ore," but it is there also called Ferriferous ore. In Ohio it has a wide distribution and is known under sevoral names, among whicll are "Baird" ore, "Gray" ore, "Limestone" ore.

The ore generally lies in immediate contact with the limestone, in a slab-like sheet one-half to 1 foot thick, but occasionally, as in Lawrence County, Penusylvania, on the Houck farm, it locally thickens up to 20 feet, entirely replacing the underlying limestone, while again it is absent orer wide areas, or represented by nodules scattered through the overlying shales. When the Ferriferous limestone is absent, its place in the series can often be correctly assigned from the existence of this ore, as is the case in Section 97, at Nuzum's Mills, West Virginia. This bed was formerly the main ore from which the charcoal furnaces of western Pennsylvania drew their supplies, and it is still the main feeder for these furnaces in southern Ohio. In northern West Virginia some iron ore occurs at this horizon in Monongalia and Preston Counties, and a few inches of it may be seen near the coke ovens on Glady Fork, below Thomas, Tucker County, but in the Great Kanawha region and southward toward the Big Sandy it appears to be completely absent as a distinct stratum, though nodules of iron sometimes come at this horizon.

THE EERRIFEROUS LIMESTONE.

The occurrence of the iron ore just described resting upon a bed of limestone orer a wide area suggested the name "Ferriferous" which the early geologists applied to the limestone as well as the ore.

This is the most important and widely distributed limestone of the entire Coal Measure column, important both in an economic sense and as a stratigraphical horizon which with ordinary care can be unfailingly recognized by geologists as well as anyone else interested in determining the correct order of the rocks. It differs from the other limestones that we have had so far in the Lower Coal Measures, in being a genuine marine deposit, abounding in fossil crinoids, corals, brachiopods, lamellibranchs, univalves, etc., a list of the more common forms of which is given on pages 46 and 47, Report QQ, Second Geological Survey of Peunsylvania.

In P'ennsylvania this limestone is confined to the counties west from Chestnut Ridge, attaining its maximum development in Clarion, Armstrong, Butler, Beaver, and Lawrence, where it is frequently 25 feet thick, or even more, and seldom less than 10 except it has locally thinned away entirely.

This limestone enters Ohio at Lowellville on the Mahoning River with a thickness of 15 feet, but westward it changes very much from its Pennsylrania type, becoming reduced in thickness, sometimes entirely absent, and occasionally splitting into two beds separated by 15 to 50 feet of shales, the lower one of which has been called the Putnam Hill limestone from its occurrence in an eminence of that name at 
Zanesville. In one way or another, however, it has been satisfactorily traced by Orton across the Ohio field to where it enters Kentucky from Hanging Rock.

A layer of flint or "buhrstone" is often incorporated with the top of this bed in Penusylvania, and the same thing holds true for Ohio, but below this the rock is generally gray for 10 to 15 feet and of great purity, being especially prized as a flux in the smelting of iron ore, and used almost exclusively for this purpose in the Pittsburgh region. The lower portion of the stratum is generally of a bluish color, and its layers are shaly, being interstratified with thin films of clay and other impurities, and occasionally a distinct bed of shale separates the blue layers from the gray above. Hence it seems very probable that, as Prof. Orton once suggested, this shale layer probably increases in thickness through some regions of Ohio, thus separating the upper portion, as the "Gray" limestone, from the lower or blue part, which has been called the Putuam Hill. On one point, however, in this connection, the writer can. not fully agree with Prof. Orton, and that is concerning the presence of workable coal beds between these two divisions of the limestone. There is certainly none at Zanesville, the typical locality for the Putnam Hill limestone (Section 104), neither is there any at Shawnee (Section 105), nor at New Lisbon (Section 103), nor Sprucevale (Section 102), so that it appears more probable that the supposed workable coal between the two layers of the limestone is founded apon an error in identification.

Another characteristic of this limestone is that when it becomes thin and impure it almost always exhibits the "cone-in-cone" structure, though there are other horizons in the Coal Measures which show the same feature, notably the Mercer limestones.

The most northern point at which this limestone has been found in Pennsylvania is in the southern portion of McKean County, where Mr. Ashburner identifies with it a siliceous limestone occurring in the vicinity of Clermont.

In the North Potomac coal basin this limestone has been seen by the writer near Gorman, Garrett County, Maryland, and also below Thomas, along Glady Fork of Black Water. In each case, however, the deposit is entirely different from the marine type of western Pennsylvania and Ohio, and resembles more the fresh water limestones under the Freeport coals, since no marine fossils were observed at either locality; in fact there is no point in West Virginia or Maryland where the marine type of this limestone is known to exist, so far as the writer is aware.

Along the Great Kanawha River, in the vicinity of Cannelton, a bed of siliceous limestone occurs 75 to 100 feet under the Lower Kittanning coal, and it has been identified with the Ferriferous limestone horizon as shown in Section 115. It occasionally exhibits the "cone-in-cone" structure but is not fossiliferous.

Immediately under the Ferriferous limestone in western Pennsyl- 
vania there are often $\mathbf{5}$ to $\mathbf{1 0}$ feet of black fossiliferous shales, especially when the limestone is thin or locally wanting, so that the horizon can thus be frequently recognized without the presence of the limestone since the fossils in the shales are practically the same as in the latter.

THE CLARION COAL.

Mr. H. Martyn Chance has recently shown $(\nabla \nabla$, Second Geological Survey of Pennsylvania) that the coal bed which comes so elose under the Ferriferous limestone in western Pennsylvania, and was formerly called the Srrub-grass coal, is really an off-shoot from the Clarion, and hence it is unnecessary to retain the name Scrub-grass, which should be replaced with Upper Clarion.

The main bench of the Clarion coal occurs through western Pennsylvania at an interval of $\mathbf{1 0}$ to 30 feet below the Ferriferous limestone. Its usual thickness is about 3 feet, though it often swells to 4 or 5 . Wheu well developed it generally contains one or two parting slates, and one of them thickening up causes the upper bench to approach the Ferriferous limestone, and it was then taken for a separate coal by the geologists of the First Pennsylvania Survey, but, as Chance suggests, this should be called the Upper Clarion bed in view of its origin. This upper member is thick enough to mine in only a limited area around the northern outcrop of the same in Clarion, Butler, and Jefferson Counties.

The Lower or main Clarion bed is of considerable importance in Pennsylvania, and generally furnishes some areas of good fuel in nearly every county where its outcrop occurs, though as a rule the coal is rather high in both ash and sulphur.

In eastern Ohio this bed acquires some importance in the vicinity of Leetonia and New Lisbon, and is there often parted by a vein of fire clay 1 to 4 feet thick, the upper coal alone being mined, and varying in thickness from $2 \frac{1}{2}$ to $3 \frac{1}{2}$ feet. Prof. Orton has also shown that the Canfield cannel of Mahoning County belongs to the horizon of the Clarion bed.

Westward from the eastern tier of Ohio counties, the Clarion coal disappears according to Orton and is of no more importance until Vinton and Jackson are reached, but this conclusion is based upon his present view of the Putnam Hill limestone, which he once regarded as a "split" from the Ferriferous of Pennsylvania, but which he now appears to reject, since he puts the Clarion coal between this latter limestone and the upper or "Gray" one, and identifies the coal underlying the Putnam Hill limestone as the Brookville bed of Pennsylvania. The writer has elsewhere expressed his doubt of the existence of any workable coal between these two limestones, believing that the identifications on which the conclusion was founded are erroneous, so that if we substitute Olarion coal for "Brookville" in Prof. Orton's Ohio series, 
all difficulties concerning the disappearance of the Clarion coal between eastern Ohio and Perry County vanishes, and the Clarion becomes one of the regular and persistent beds of the series clear across Ohio as it does in Pennsylvania. In the Zanesville section (104) the writer has indicated his views as to the equivalency of these members of the Ohio series.

The Clarion coal attains its maximum thickness in Stark County, Ohio, where it is 6 feet thick and a very fair steam coal, according to Orton.

In northern West Virginia this bed is generally present in the section, but is usually slaty and too impure to be valuable, so that it has never been mined in that part of the State.

Section near Eagle, Fayette County, West Virginia.-Along the Great Kanawha River a coal bed, which appears to come at this horizon, has been largely developed for coking purposes in the vicinity of Eagle; Fayette County, and hence is locally known as the Eagle vein. Where best developed there, it varies from $3 \frac{1}{2}$ to $4 \frac{1}{2}$ feet in thickness, and is a splendid coking coal, having the following structure in the vicinity of Eagle:

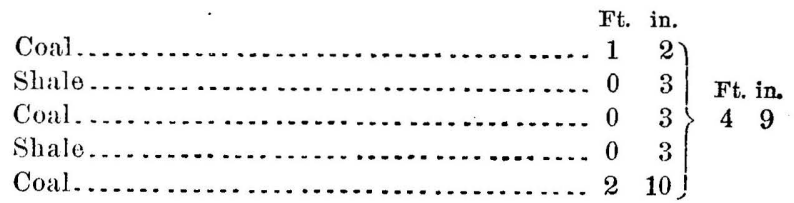

In passing up the Kanawha from Eagle the npper shale parting of this bed gradually thickens till at the mouth of Armstrong Creek, 3 miles above, it becomes 20 feet thick and the coal has the structure given: in Section 115.

The interval between this bed and the Lower Kittanning varies between 120 and 200 feet along the Great Kanawha, thickening up to the latter figures at Brownstown (Section 114), but southward from this in Wyoming County the interval swells still further to 230 feet in the vicinity of Oceana, as shown in Section 117, where the coal in question. has a thickness of 5 to 6 feet and is known as the "coking" vein. There is evidently a wide area of this coal between the Kanawha and Big Saudy Rivers in which it will prove a valuable coking coal.

A bed of excellent fire clay often underlies the Clarion coal both in Pennsylvania and Ohio, being second in value only to the Kittanning clay above, and often rivaling it in thickness.

The interval below the clay down to the next coal bed (Brookville) varies greatly both in thickuess and in the rock material which occu. pies it. Occasionally the series ends with the Clarion underclay, which rests immediately on top of the next lower or Conglomerate Measures, while again, shales and a sandstone termed by Chance the Clarion sandstone occupy this interval, which in Pennsylvania is seldom more thau 30 to 50 feet thick. 
In Ohio the interval below the Clarion clay down to the top of the Pottsville Measures is seldom more than 30 feet, the same being true in northern West Virginia, as may be seen from Sections 96 and 97.

On the Great Kanawha River the interval from the Clarion or Eagle coal down to the top of the Pottsville Measures thickens to nearly. 300 feet, and consists of.a succession of shales and sandstones, in which occur two thin limestones and two or three thin coal beds. None of the latter attain a thickness of 3 feet, however, anywhere between the Kanawha and Big Sandy Rivers, so that the workable coals of this series in that region really end with the Clarion (Eagle) bed.

Two or three rocks in this interval of 300 feet in southwestern West Virginia require more particular notice. One of them, and the uppermost, is a very pure seam of coal, which at Eagle comes only 20 feet below the main Eagle bed, and is $1 \frac{1}{2}$ feet thick. I have termed it the Little Eagle coal, since it is possibly a "split" from the main bed above. To the south it appears to be quite persistent, since it occurs in Wyoming County in every section; but the interval separating it from the Eagle bed has there swelled to 65 feet (Section 117) and the coal has thickened to 27 inches of the same excellent fuel as on the Kanawha.

THE EAGLE LIMESTONE.

Another rock worthy of mention in this Kanawha series is an impure limestone which oceurs near Eagle at an interval of 75 feet under the Eagle coal. It is only about 1 foot thick, quite dark, fossiliferous, and exhibits the "cone-in-cone" structure to a wonderful degree, being locally known as "black marble." The stratum is immediately underlaid by dark shales, which are crowded with marine fossils of the same type as those found in connection with the Ferriferous limestone in Pennsylvania and Ohio; in fact, so many of the species are identical, and the limestone itself so closely resembles the Ferriferous when thin, that sometimes $I$ have been inclined to think that the two beds may possibly be identical, though this would seem to be impossible from the structure of Section 115, in which the whole lower coal series is exposed both above and below this stratum. If it should turn out to be identical with the Ferriferous, however, then the Eagle coal would be the Lower Kittanning, instead of the Clarion, and the Campbell's Creek bed the Middle Kittanning, or Neisonville seam of Ohio, instead of the Lower Kittanning. The reader will understand the difficulty of correlation when he remembers that the lower coal series is less than 200 feet thick in the Hocking Valley, Ohio, while here, only 120 miles southward, the same series has swelled out to 1,000 feet.

The fossiliferous type of the limestone and its accompanying fossiliferous shale have never been seen by the.writer, except in the vicinity of Eagle, and hence I have preferred to regard it as a local deposit below the horizon of the Ferriferous, since the fossils of the Lower Coal Measures have the same general facies at all horizons.

Bull. $65-12$ 
THE BROOKVILLE COAL.

At the very base of the Lower Coal Measures, except the intervening underclay, there occurs in Jefferson, Clarion, and some other counties of Pennsylvania, a bed of usually slaty and otherwise impure coal, which was long ago named the Brookville bed, from its supposed occurrence near the town of that name in Jefferson County. This coal acquires some local importance around the northern margin of the coal field in Jefferson, Clarion, Butler, and Mercer Counties, but southward and westward it thins away and is often absent even as an impure bed, there being no coal whatever at this horizon where the Pennsylvania series enters Ohio ; and if I am correct in identifying Prof. Orton's "Brookville" coal, (Vol. V, Ohio Geology) with the Clarion of Pennsylvania, then the Brookville coal is generally absent, or at least seldom workable anywhere in that State.

Very frequently the Brookville coal is represented in Pennsylvania by only a bed of black slate or coaly shale, resting on the top of the Conglomerate Measures, and this is the case in northern West Virginia, there being no workable coal at this horizon anywhere in that State, so far as the writer is aware. Even in the Kanawha field, where this lower portion of the column is so greatly thickened, the largest coal bed referable to the Brookville horizon is the one in the Wyoming County section (117), and this is only 22 inches.

On the Great Kanawha a bed of very bituminous shale (Section 115), from which lubricating oil was once manufactured, may possibly represent the Brookville coal horizon, since it is the lowest bituminous stratum in the series there.

Below this coal in Pennsylvania, and resting immediately on the top of the Conglomerate series, there is sometimes a good bed of fire clay, and Mr. Chance refers to this horizon the clay which is mined so extensively in Clearfield County, at Blue Ball, Wallaceton, and other points along the line of the Tyrone and Clearfield Railroad. 
C H A P T E R VI.

\section{THE POTTSVILLE CONGLOMERATE SERIES.}

THICKNESS, CHARAC'TER, AND EXTENT.

Beneath the lowest member of the last described series there comes in a group of rocks (No. XII) which are nearly always so different from those in any other portion of the Carboniferous system that all geologists have regarded them as worthy of being placed in a distinct series. To this series several names have been given. The early geologists of Pennsylvania called it the "Seral" or "Great" Conglomerate, while in 'Virginia it has generally been named the No. XII Conglomerate, or simply No. XII. Prof. Lesley has in recent years, however, given it the geographical designation of Pottsville Conglomerate, from the great development of the series near the town of that name, while Prof. Fontaine, following the Pennsylvania custom of naming the several coal series after prominent rivers along which the beds are exposed, has suggested the name New River series, from that region of West Virginia where its coal beds attain a great development.

But since only one geographical name is admissible for the series, and as the term Pottsville is now so well ingrafted upon geological nomenclature through the numerous reports of the Second Geological Survey of Pennsylvania, it is thought best to retain it for the series, and at the same time retain New River for the name of the coal group which attains such prominence along that stream, thus putting it on a par with the Mercer group, which occurs in the upper portion of the series.

As exhibited everywhere in Pennsylvania and West Virginia, this series is very sharply set off from the Lower Coal Measures above and the Lower Carboniferous below, since in both cases there is a great change in the lithology, so that the geologist finds no difficulty in determining where the Pottsville series begins as well as where it ends.

The series as a whole possesses a large amount of hard, white, or grayish white sandstone, much of which is often conglomeritic. The sandstones are harder, more compact, and siliceous than any in the Lower Coal Series above. Bowlders of these sandstones take a smooth polish when rolled along river beds, but this is not the case with most sandrocks above this horizon.

The fossil contents are also different from those of any sandstones above, since here for the first time in descending the column of rocks 
do we find sigillariæe and the large lepidodendra very abundant in sandstones.

At the base of the series the change in lithology and life remains is even more abrupt, since with the disappearance of the white or gray saudstones and conglomerates, limestones, red shales, and green micaceous sandstones appear, in which plant remains are rare and the fossil trees are all small.

The Pottsville being composed mainly of very hard sandstones, the grains of which are cemented by silica and peroxide of iron, becomes almost indestructible by ordinary atmospheric influences, and has thus proved a most important factor in determining the topography of the Carboniferous system. Whenever these beds come to the surface in West Virginia and Penusylvania, wild and rugged scenery is sure to be found. Rapid rivers, high waterfalls, great cliffs, and barren.regions generally, mark the lines where these rocks emerge to daylight. The loftiest peaks of the Alleghany Mountains owe their origin to this friendly mantle, while its upturned edges have preserved -many coal basins from complete destruction. The deep gorges, narrow cañons, and wild scenery of the Alleghany, Youghiogheny, Cheat, Monongahela, New, Guyandotte, and Big Sandy Rivers are all carved out of these rocks. The Falls of the Yough, Cheat, Tygart's Valley, Kanawha, and the "Roughs" of the Guyandotte and Big Sandy are all made by these same beds.

It was formerly supposed that a vast sheet of pebbly material underlaid all of the true Coal Measures, and that it was destitute of coal; but the recent work of the Second Geological Survey of Pennsylvania has shown that the series is very complex, consisting of several distinct sandstone members, between which occur shales, several coal beds, and occasionally some limestone.

In Ohio it happens that the upper members are not so massive as in Pennsylvania or West Virginia, while the coal beds which are prominent only around the margins are well developed there, so that the Ohio geologists have classed the upper portion with the Lower Coal Measures, and retained only the lowest member of the series, viz, a stratum termed the Sharou Conglomerate, as the representative of the whole series elsewhere. I shall show in the following pages that the whole series is easily recognized in Ohio, and that the western Penn. sylvania type of these measures can be traced across Ohio, and hence for the sake of uniformity in nomenclature the Ohio geologists should cut off 100 to 150 feet from the bottom of their Lower Coal Measure column and combine it with the Sharon Conglomerate below, thus making seyeral members for the series instead of a single stratum.

The coals of the Pottsville zeries, unlike those in the measures above, are persistent and valuable only around the margins of the Appalachian coal field, and for the most part only where their outerops are above the level of the prineipal drainage streams, so that the conditions for- 


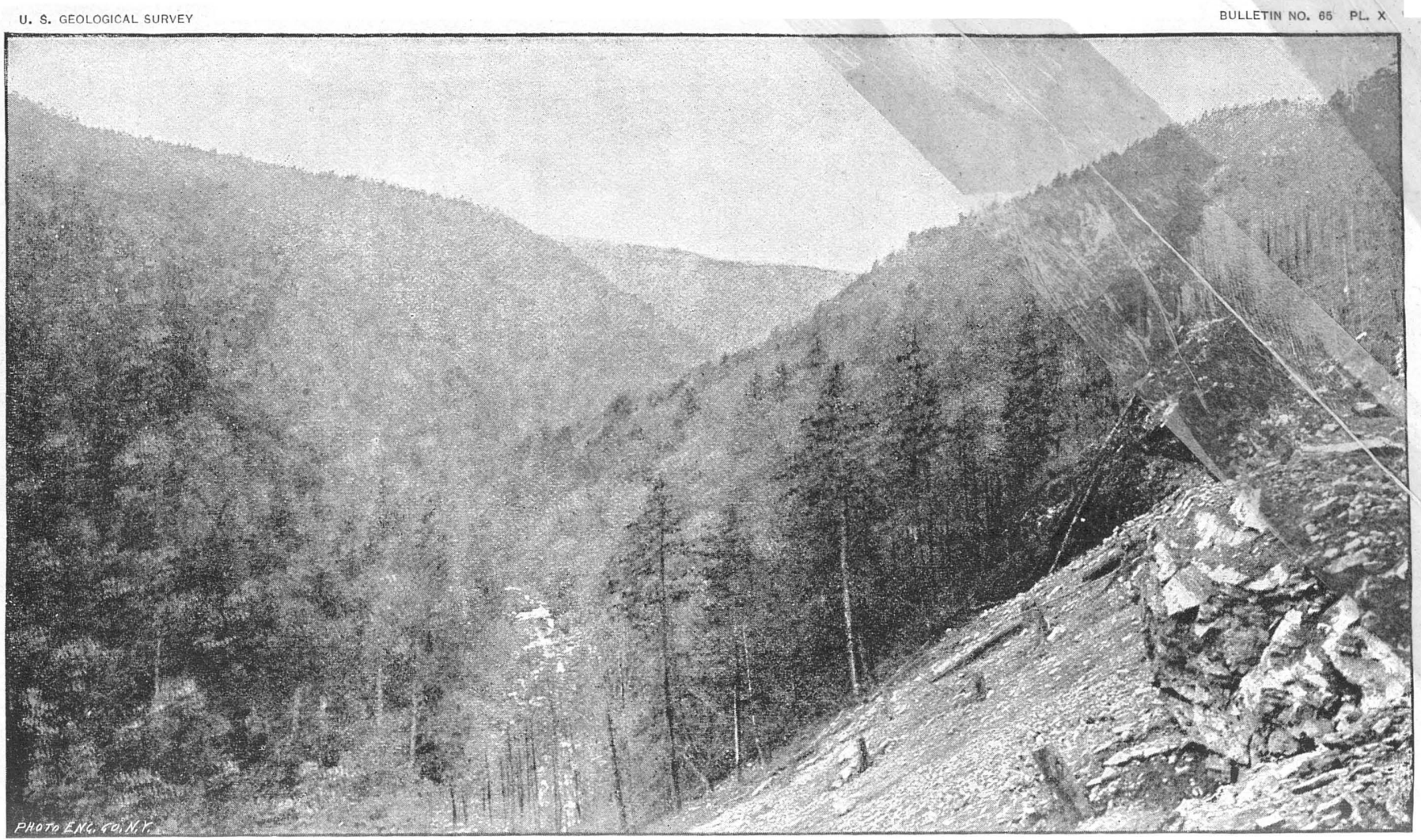

THE POTTSVILLE CONGLOMERATE TOPOGRAPHY IN BLACKWATER CANYON, TUCKER COUNTY, WEST VIRGINIA. 

merly supposed to apply to the Lower Coal Measures do actually prevail with reference to the coal in this series, since hundreds of carefully kept well records testify to the absence of any workable coal beds in this series over all except the outer rims of the Appalachian field. This same fact is visible to the eye in passing inward toward the center of the field down any one of the great rivers which drain into the Ohio. The Sharon coal disappears south ward along the Shenango and Mahoning rivers long before its horizon dips down to water level; the New River coals fade out of the section before their outcrops touch the stream to the north; the great bed at Pocahontas does not extend indefinitely down the Guyandotte and Tug rivers, but only 20 to 30 miles, until it dwindles away to a bed too thin to mine, so that should a shaft be sunk to these beds 30 or 40 miles from their southern or northern outcrops respectively, the same massive, pebbly, white sandstones would be found, but instead of inclosing valuable coal beds they would hold only thin streaks of coal and some black slates.

Another peculiarity about these interconglomerate coals is the great difference in quality between those around the southern rim of the Ap. palachian field and those around its northern border, for in western Pennsylvania and across Ohio they are all open burning, hard, and generally known under the name of "block" coals, which can be used in furnaces in the raw state, while to the south, through West Virginia, Virginia, and on into Tennessee and Alabama, these same coals are very soft and tender, always cementing and making good coke. This difference is connected with different conditions of accumulation, there probably being less moisture in the great peat swamps at the north, and the vegetable accumulations taking place not under water, but partially at least in the open air. This much would be indicated by the innumerable films of mineral charcoal which characterize the northern coals and render them non-cementing. To the unequal rate of subsidence on the two sides of the Appalachian basin is doubtless owing the conditious which brought about the difference in the character of the coals.

Another peculiarity is the great purity of these early formed coals, their freedom from injurious quantities of ash and sulphur, both at the north and south. This also appears to be due to the conditions attending their deposition rather than to any difference in vegetable tissues, since just previous to the spread of these early coal marshes the whole Appalachian region was sheeted with a thick layer of clean graviel and white sand, thus effectually covering up the muddy deposits of a former epoch and causing the streams which drained into the peat bogs of that time to be pure and clear like our own mountain brooks of the present.

The thickness of the Pottsville series varies greatly in different portions of the Appalachian basin. In the bituminous regions of Pennsylvania, and every.where in Ohio, they rarely exceed 300 feet and seldom go below 150; but southwestward throngh West Virginia they begin to swell out, reaching 700 feet at the head of Black Water, in 
Tucker County; 1,400 on the New River in Fayette, and probably 1,800 at the Kentucky liue on the Tug River, in McDowell. Map Section $\mathrm{C}$ will exhibit the manner and rate at which these beds thicken southeastward from their northwestern outcrop in Obio. The data for its construction were obtained from surface measurements and oil-well borings, several of which have been recently made along the Great Kanawha.

This series is also the repository of much salt water, as well as some oil and gas. The celebrated brines on the Great Kanawha, as well as at Pomeroy and many other localities along the Ohio River, come in its basal members, while the "first gas sand" of the Cannonsburg and Hickory region of Washington County, Pennsylvania, is found in the upper half of the same. This rock is also gas-bearing near Glover's Gap, on the Dodd farm, and near Mannington, Marion County, West Virginia, on the Snodderly farm.

We shall now give a number of sections in different portions of the Appalachian field, illustrating the character and thickness of the Pottsville series, and, as with the Lower Coal Measures, shall begin at the northeastern end of the field and proceed southwestward to the Ken. tucky line.

Section in Fox Township, Elk County, Pennsylvania.-The following section (Fig. 122) exhibits the structure of these beds in Fox Township, Elk County, Peunsylvania, as given by Ashburner (Report RR, p. 186, Second Geological Survey of Penusylvania):

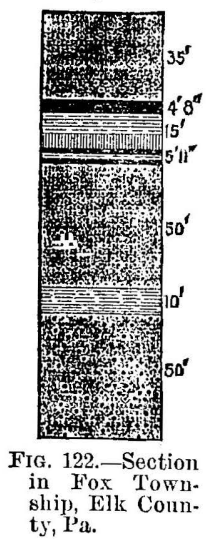

Fox Tounship, Elk County, Pennsylvania.

[Sce map, D r.]

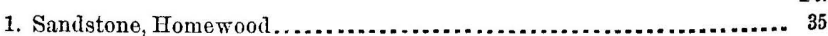

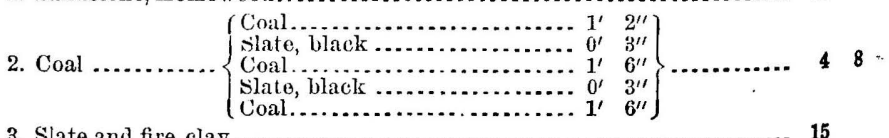

3. Slate and fire clay ............................................. 15

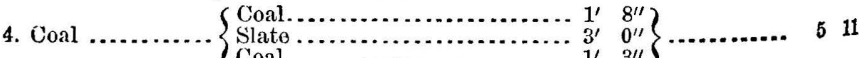

5. Sandstone Conoquenessing ..................................... 50

6. Shale and slate............................................. 10

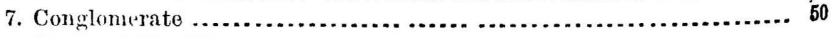

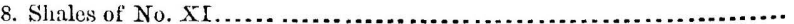

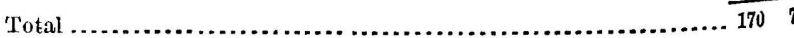

As will be observed, the series is thin in this region, and it seems to decrease still more in Tioga County further to the northeast, where it is less than 100 feet and all in one solid bed.

Section at Clearfield, Clearfield County, Pennsylvania.-At the town of Clearfield, in the county of the same name, a well was once bored for salt. It begins near the top of these measures, and the record shows the following structure (Fig. 123), as given in Report $\mathrm{H}$, Second Geological Survey of Pennsylvania: 


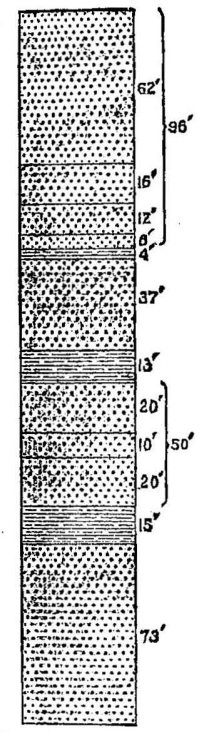

FIF, 123. - Section at Clearfield, Clearfield County, $\mathbf{P}$ a.

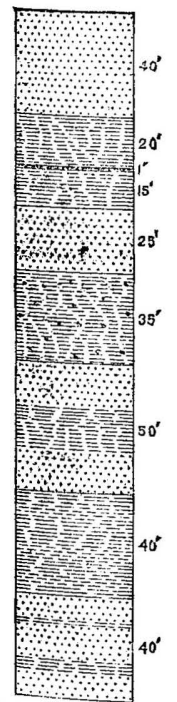

Fig. 125. - Section near Patton Sta tion, Clarion County, $\mathrm{Pa}$.

Cllearfield, Pennsylvania, from boring.

[See map, E s.]

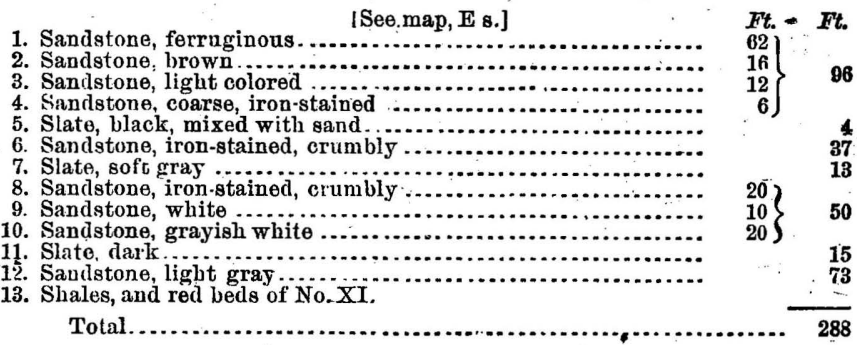

Section near Brookville, Jefferson County, Pennsylvania.-In the vicinity of Brook. ville, Jefferson County, Pennsylvania, these beds exhibit the following structure (Fig. 124), as learned from surface obser. vations combined with the record of the Brook ville Gas Company's well No. 2:

Brookville, Jefferson County, Pennsylvania.

[See map, $\mathbf{E}$ p.]

1 Sandstone, massire, Homewood

2. Shales and sandstone ............................

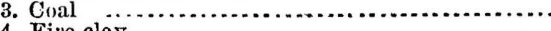

4. Fire clay ..........

5. Sindstuy

6. Conconled .......................................

7. Sandstone, massive ...............................

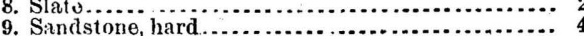

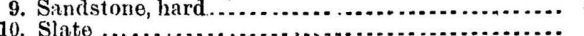

11. Sandstone, hard................................. 22

12. Red sliales of No. XI.

Total

Ft. in.

2

\section{0}

\section{0} 0 4 $372 \quad 2$

Here the series has thickened consideraably, and the triple structure of its sandstones so often found in Pennsyivania becomes prominent. No. 4 appears to occupy the horizon of the Mount Savage fire clay. Section near Patton Station, Red Bank Tounship, Clarion County, Pennsylvania.-

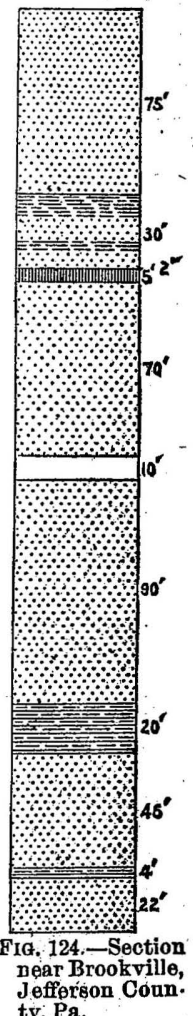
Near Patton Station, Red Bank Township, ty; Pa.

Clarion County, Pennsylvania, the rocks of this series exhibit the following structure (Fig. 125), according to Mr. H. Martyn Chance (Report VV, p. 116, Second Geological Survey of Pennsylvania):

Patton Station, Red Bank Township, Clarion County, Pennsylvania.

[See map, E o.]

Feet.

1. Sand stone, hard, massive, Homewood ........................... 40

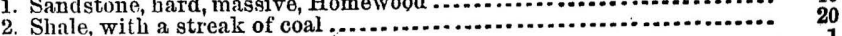

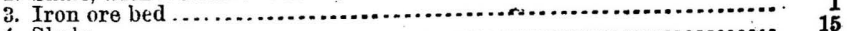

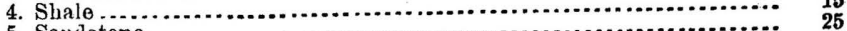

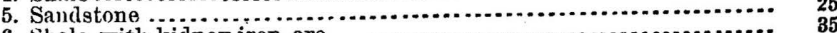

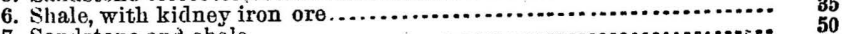

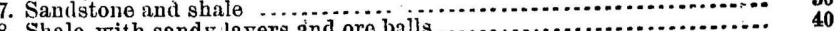

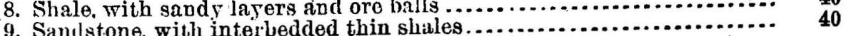

9. Samilstone, with interbedded thin shales $\ldots \ldots \ldots \ldots \ldots \ldots \ldots \ldots \ldots$
10. Red shale.

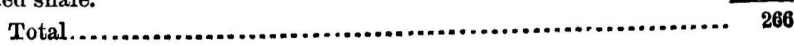


Scction at Kellersburg, Armstrong County, Pennsylvania.-Near Kellersburg, Armstrong Comnty, Pennsylvania, these measures have the

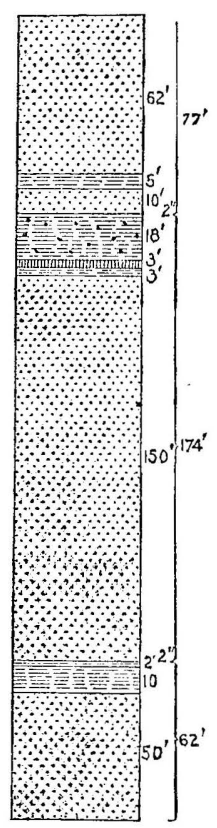

FIf. 126.-Section at Kellersburg, A rmstrong Connty, Pa.

following structure (Fig. 126), according to Mr. William G. Platt (H 5, p. 194, Second Geological Survey of: Pennsylvania):

Section at Kellersburg, Armstrong County, Pennsylvania.

[See map, F o.]

1. Sanilstone, massive, Homewood

2. Slıales

3. Samlstone.

4. Coal (Mercer group)

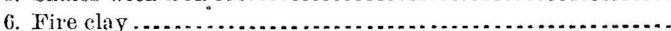

7. Sluales.

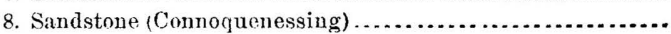

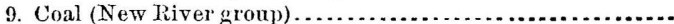

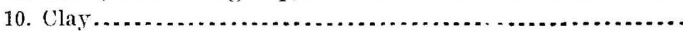

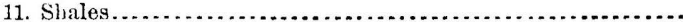

12. Sandstone

Total
Ft. Ft. in.

62) 77

$10 \mathrm{j}$

02

18

3174

150)

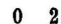

2)

50 i

$313 \quad 4$

Here two prominent coal horizons are represented by mere streaks, the upper one being that of the Mercer group of western Pennsylvania and Ohio, while the lower is the Sharon coal horizon of the latter States and the New River group of West Virginia.

Section under Pittsburgh, Pennsylvania.-Under Pittsburgh, Pennsylvania, we learn the structure of this series from the careful record (Fig. 127) of the Jones \& Laughlin gas well No. 2, as giveu in the Pemmsylvania Geological.Survey, 1886, p. 734:

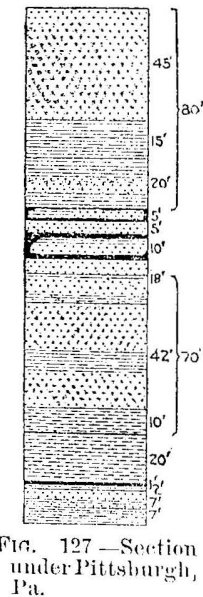

Under Pittsburgh, Pennsylvania; boring.

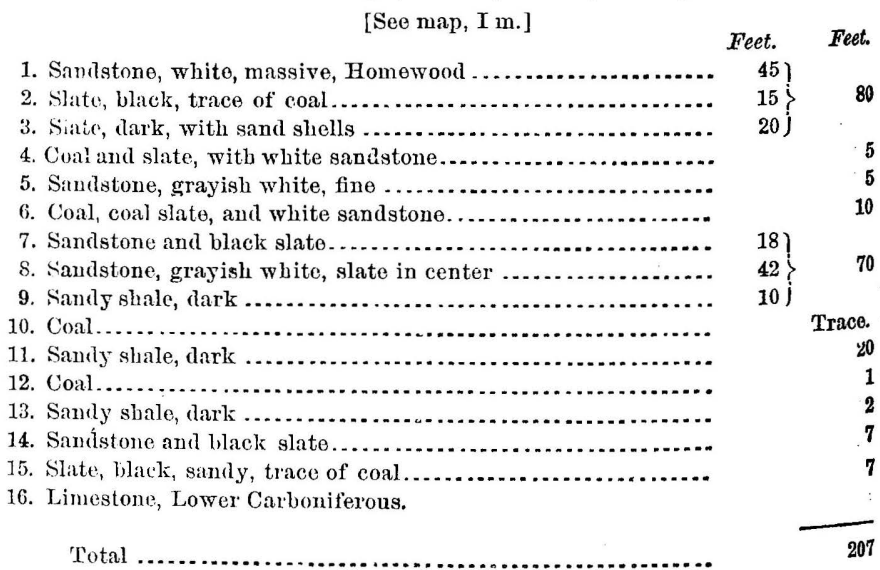

Section under Murraysville, Pennsylvania.-Under Murraysville, Westmoreland County, Penusylvania, the structure is thus exhibited (Fig. 
128) by the record of the Philadelphia Company's gas well No. 49,

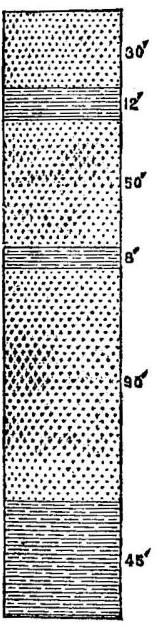

Fig. 128.-Section un der Murraysville.

McCutcheon farm, according to William S. Stevenson, assistant superintendent of the company:

Under Murraysville, Westmoreland County, Pennsylvania (boring).

[See map, I n.]

Feet:

1. Sandstone, gray, hard, close...

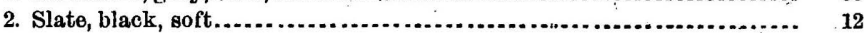

3. Sandstone, gray, hard, close ..................................... 50

4. Slate, black, soft........................................................ 8

5. Sandstone, gray, hard, close........................................ 90

6. Slate, black, soft................................................ 45

7. Red shale of No. XI.

Total.

235

Section under Washington, Pennsylvania.-Under Washington, Pennsylvania, the structure is thus given (Fig. 129) by Prof. Linton from the careful record he kept of the Thayer oil well (Geological Survey of Pennsylvania, p. 765, 1886):

\section{Under Washington, Pennsylvania (boring).}

$$
\text { [See map, J k.] }
$$

Ft. in. Ft. in.

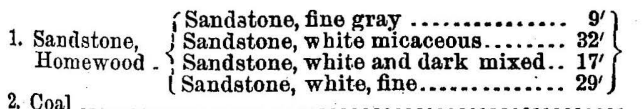

2. Coal ( Sandstone, white, fine.............. 29'

3. Sandstone, white, hard, salt water

4. Sandstone, fine, white and dark

5. Shale very dark, hard shells.

7. Shale, black

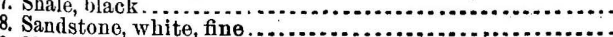

9. Shale, black, and coal

10. Sandstone, close grained

11. Shale and slate.

12. Shale and shells

13. Shale, black, top of Lower Carboniferous beds.

Total

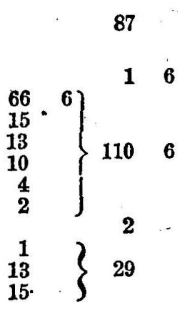

230

Here, as at Pittsburgh (Section 127), a careful record discloses thin representatives of the Mercer and

New River coal groups Nos. 2 and 9, re-

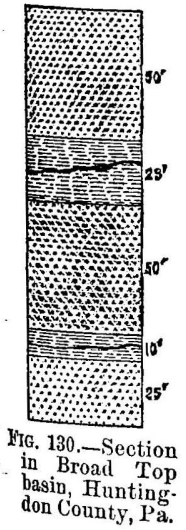
spectively.

Section in Broad Top basin, Huntingdon County, Pennsyl. vania.-In the Broad Top basin of Huntingdon County, Pennsylvania, the structure of these beds is as follows (Fig. 130), according to Report $T^{3}$, p. 69, Second Geological Survey of Pennsylvania:

Broad Top basin, Huntingdon County, Pennsylvania.

[See map, I t.]

Feet.

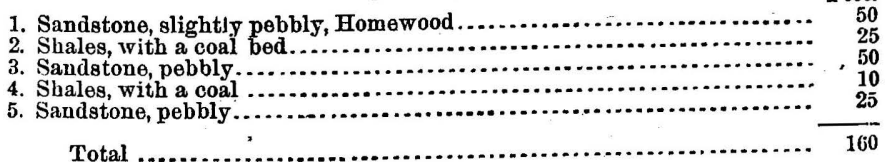

Total

The triple structure of the sandstones with intervening coal horizons is noteworthy here. 
Section near Wellersburg, Pennsylvania.-At the northern end of the Georges Creek or Cumberland coal basin, near Wellersburg, Somerset

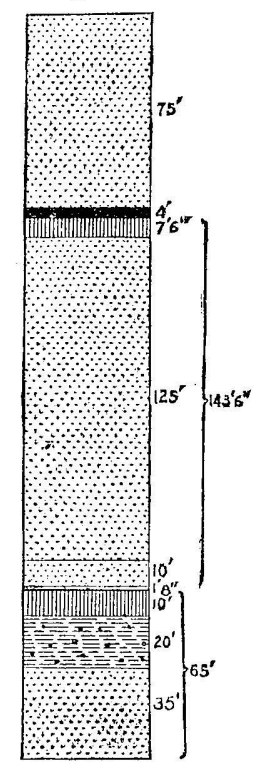

FIg. 131.- Section near Wellersburg, Pa.

County, Pennsylvania, these beds show the following structure (Fig. 131) in the gap of Gladden's Run, through the easternmost ridge of the Alleghanies:

Gladden's Run, Somerset County, Pennsylvania.

[See map, L q.]

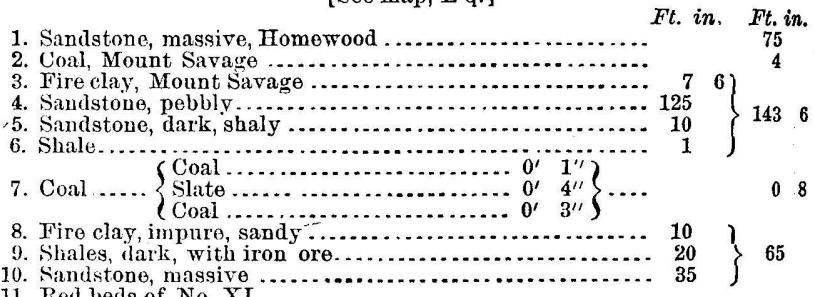

10. Sandstone, massive
11. Red beds of No. XI

Total

This section shows the horizon of the famous Mount Savage fire clay to be in the Mercer coal group. No. 4 represents the Connoquenessing sandstones, while No. 7 is probably at the horizon of the Sharon coal.

Section near Piedmontand Westernport, Mineral County, West Virginia.-The Pottsville conglomerate beds thicken very rapidly in passing southward from the Pennsylvania line through Maryland and West Virginia along the Alleghany Mountain region. This is shown by the following section (Fig. 132), taken on the North Potomac, at Piedmont and Westernport, where that stream cuts through the East Front Ridge of the Alleghanies:

Near Piedmont, Mineral County, West Virginia.

[See map, $\mathbf{N}$ p.]

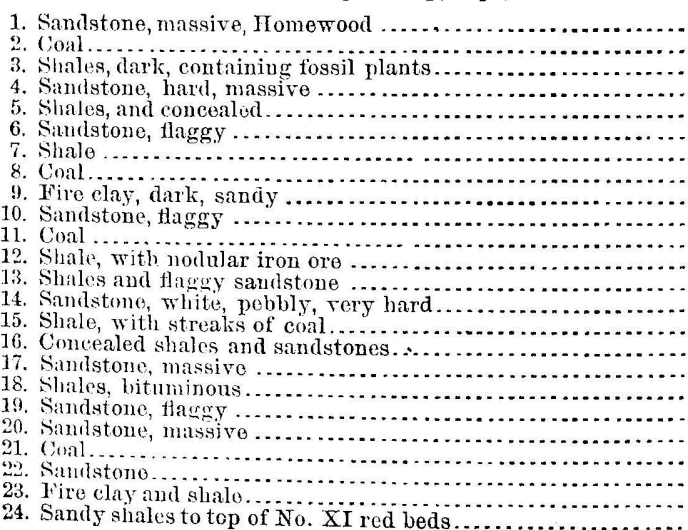

Total

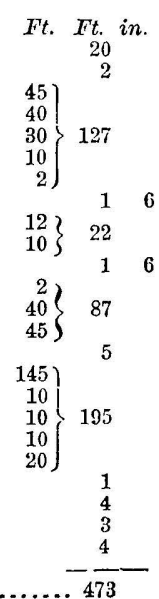

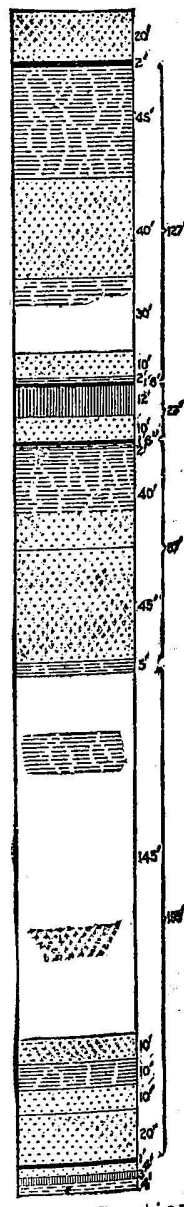

Fig. 132.-Section near Piedmont, Mineral County, W. Va. 


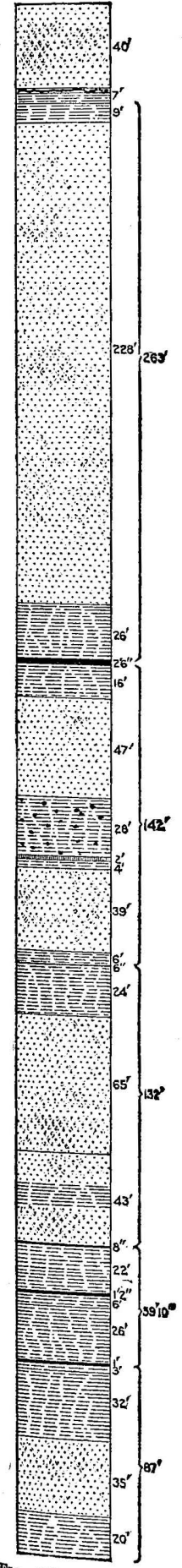

Section on Black Fork of Cheat River, Tucker County, West Virginia.-In Tucker County, West Virginia, 50 miles south-southwest from Piedmont, in the gap made by the Black Fork of Cheat River through the central portions of the Alleghany Mountains, these beds exhibit a much greater thickness than at Piedmont, as will be seen by the following section (Fig. 133) made there by Mr. James Parsons, chief engineer of the West Virginia Central Railroad :

Mouth of North Fork of Black Water, Tucker County, West Virginia.

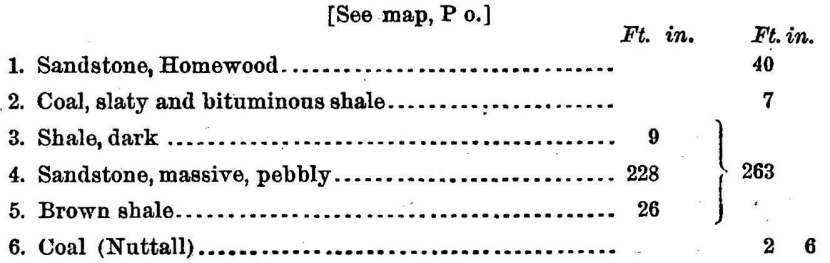

7. Shale, drab .................................... 16

8. Sandstone, massive............................. 47

9. Shales with iron nodales........................... 28

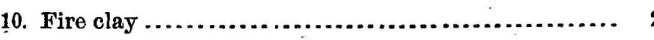

11. Shale ........................................... 4

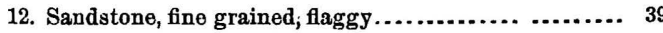

13. Shale.......................................... 6

14. Coal...............................................

15. Shale............................................... 24

16. Sandstone, massive................................ 65

17. Sandstone and shales.............................. 43

18. Coal............................................ 0

19. Shale, brown................................... 22

20. Coal ............................................. 1

21. Bituminous shale, with coal streaks................ 6

22. Brown shale................................... 26

23. Coal ............................................

24. Bituminous shale, with coal streaks................

25. Shale......................................... 32

26. Sandstone, massive............................... 35

27. Shale, brown..................................... 20

28. Red beds, top of No. XI.

Total

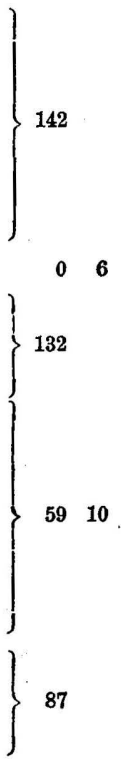

$733 \quad 10$

Here we find the entire interconglomerate coal group represented. No. 2 comes apparently at the Mercer horizon and is the "Railroad" vein along the Potomac.

No. 6 comes at the horizon of the Nuttall bed of New River, while Nos. 14 to 24 represent the lower ones Frg. 133.-Section at along that stream as well as the great Pocahontas-vein Black Water, W.Va. of
Bed Mowell and Mercer Counties, West Virginia. 
Section near Rowlesuurg, West Virginia.-A fine section of the Conglomerate coals is exposed in the cuts of the Baltimore and Ohio Rail. road, near the summit of Cheat River grade, 4 miles west from Rowles.

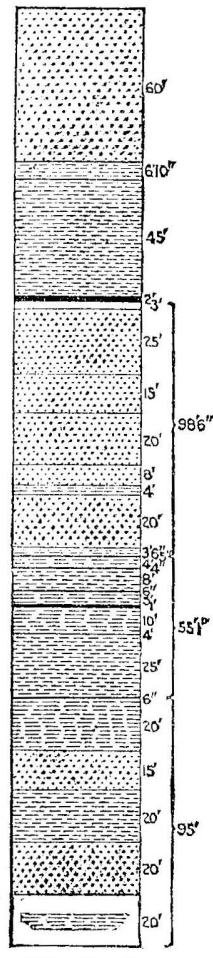

Fro. 134.-riection near Rowlesbure, IV. Va, burg, Preston County, West Virginia (Fig. 134):

Along the Baltimore and Ohio Railroad, Cheat River grade, four miles west from Roulesburg, I'reston County, West Virginia.

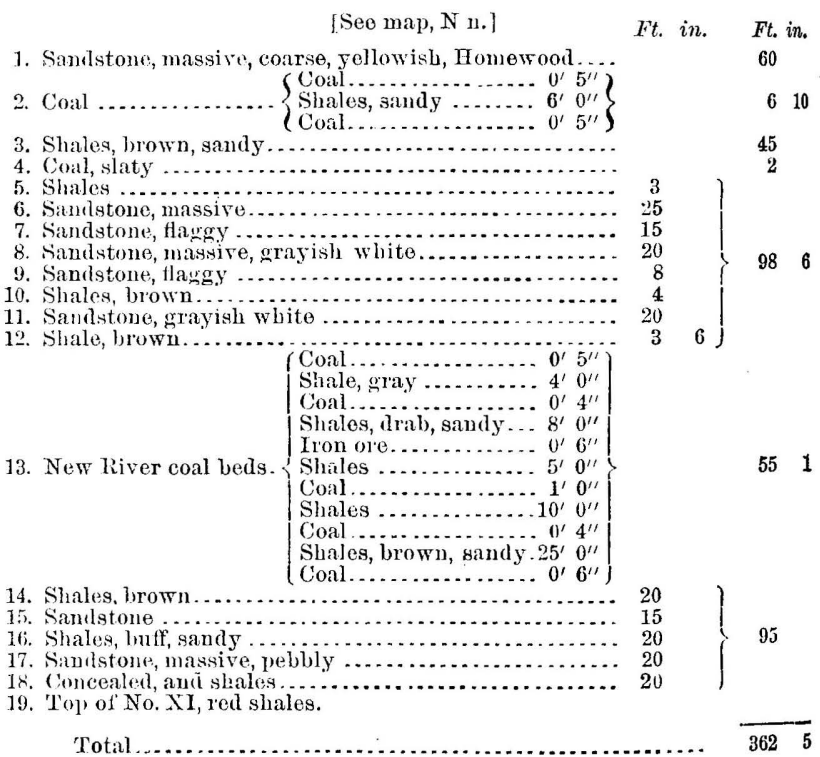

Nos. 2 and 4 represent the Mercer coal group, Nos. 6 to 12 the Connoquenessing sandstones, while No. 13 represents the New River coal group.

Section near mouth of Sandy Creek, Preston County, West Virginia.Farther northwest, down Cheat River, and in the center of the Ligonier

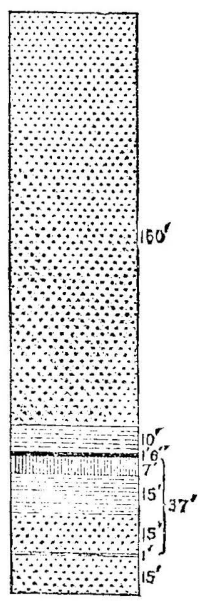
basin, the Pottsville series exhibits the following structure (Fig. 135) near the mouth of Sandy Creek, Preston County, West Virginia :

Near mouth of Sandy Creek, on Cheat River, Preston County, West Firginia.

[See map, M m.]

1. Sandstone, massive, rery pobbly near middle

2. Shales, lark.............................................. 10

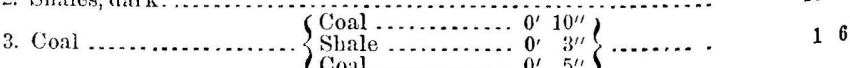

4. Fire elay . Slite, black, fissile ................................................ $\left.{ }_{15}^{7}\right\} \quad{ }_{37}$

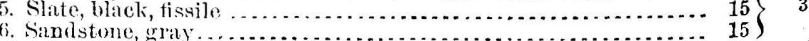

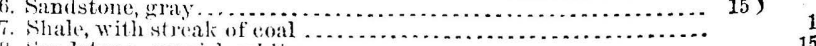

Simdstone, sravish whito

Green and red shales of $\mathrm{No} \mathrm{XI}$

Total

Here, as frequently happens, the Mercer coal group disappears entirely, while the Homewood and ConnoFin: 13i, -..tie et i on nearmuthufsindy quenessing santstones unite into one solid mass. Nos. Curnty, W. Val 3 to 7 represent the New River coal group. 
Section on Booth's Creek, Taylor County, West Dirginia.-The structure of the Pottsville beds in the region along the line between Taylor

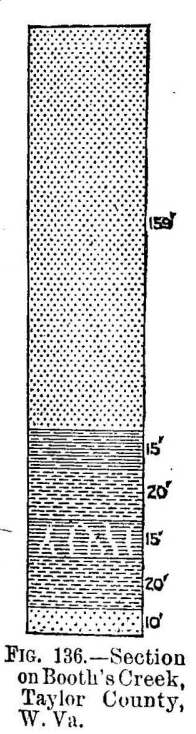
and Marion Counties, West Virginia, is learned from a boring made for oil on Booth's Creek, Taylor County, by Mr. John L. Steele, to whom I am indebted for the following record (Fig. 136):

Booth's Creek, Taylor County, West Virginia (boring).

[See map, 01]

Ft.

1. Sandstone, hard, white, pebbly ................................... 158

2. Black slate........................................................... 15

3. Shale, gray and sandy .............................................. 20

4. Shale, black ........................................................ 15

5. Shale, gray, sandy ..................................................... ${ }_{20}$

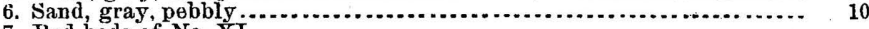

7. Red beds of No. XI.

Total

239

Here the structure is very much like that of the previous section on Cheat River, and the thickness is also nearly the same.

Section under Clarksburg, West Virginia.-Under Clarksburg, Harrison County, West Virginia, the succession is given as follows (Fig. 137), from the record of the Despard gas well, on the anthority of Prof. T. M. Jackson :

Clarksburg, West Virginia (gas well).

[See map, 0 k.]

1. Sandstone, black

2. Sandatone, white

3. Sandstone, cray.

4. Sandstone, winite

5. Sandstone, gray

7. Shale, black

8. Sandstone, white

10. Red beds of No. Xir.

Total.

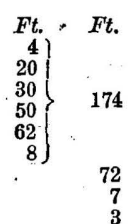

(1)

Section near Farmington, West Virginia.-Under the central portion of Marion County, West Virginia, the structure is shown by the record of the

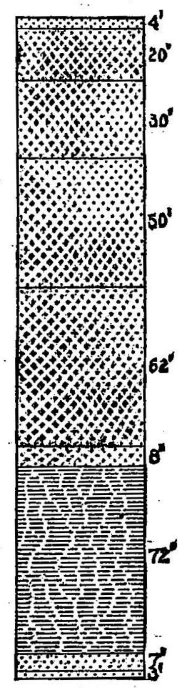

FIg. 137.-Section under Clarks. burg, W. Va. Hukill oil boring near Farmington (Fig. 138), as given in Second Geological Survey of Pennsylvania, 1886 (pp. 782, 783) :

\section{Farmington, West Virginia (oil boring).}

[See map, M 1.]

Ft.

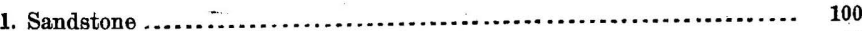

2. Shell

3. Slate .............................................................. 17

4. Black slate....................................................... 70

5. Sandstone................................................... 12

MTG. 138.-Section near Farmington,

6. Red beds of No. XI

Total. 
Section under Wellsburg, West Virginia.-Under Wellsburg, Brooke County, West Virginia, the Barclay gas well No. 1 gives the following

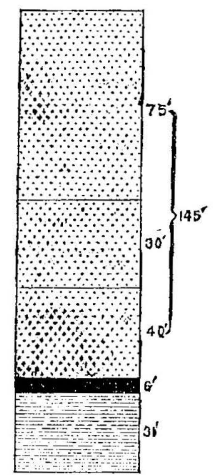

Fid. 139.--Siection nnder IV ellshurg, iv. $\mathrm{Va}$.

(Fig. 139) for these beds on the authority of Mr. Barclay :

Wellsburg, West Virginin (gas boring).

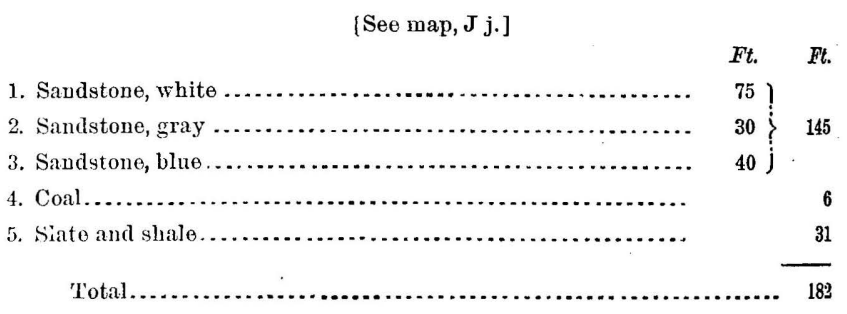

The coal reported in this section comes at the horizon of the Sharon bed of Ohio and Pennsylvania, but it was probably nearly all coaly slate or else a local thickening, since other borings put down in this region do not report it at all.

Section in Hercer County, Pennsylvania.-Along the northwestern margin of the Appalachian field in the counties of Lawrence and Mercer, bordering the Ohio State line, a series of workable coal beds make their appearance in the Pottsville series and extend along the margin of the field clear through to southern Ohio. The general section of the Pottsville series of Mercer County, Pennsylvania, given in $\mathbf{Q}^{3}$ ( p. 33), Second Geological Survey of Pennsylvania, shows the succession of these coall groups as follows (Fig. 140):

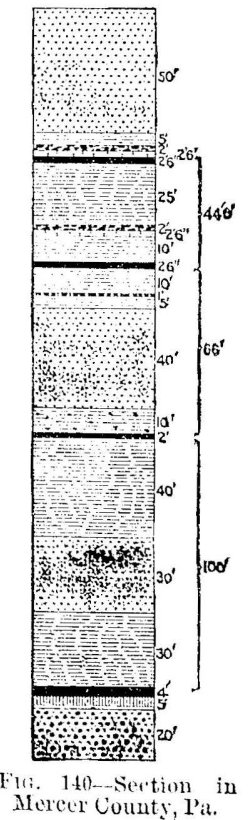

Mercer County, Pennsylvania.

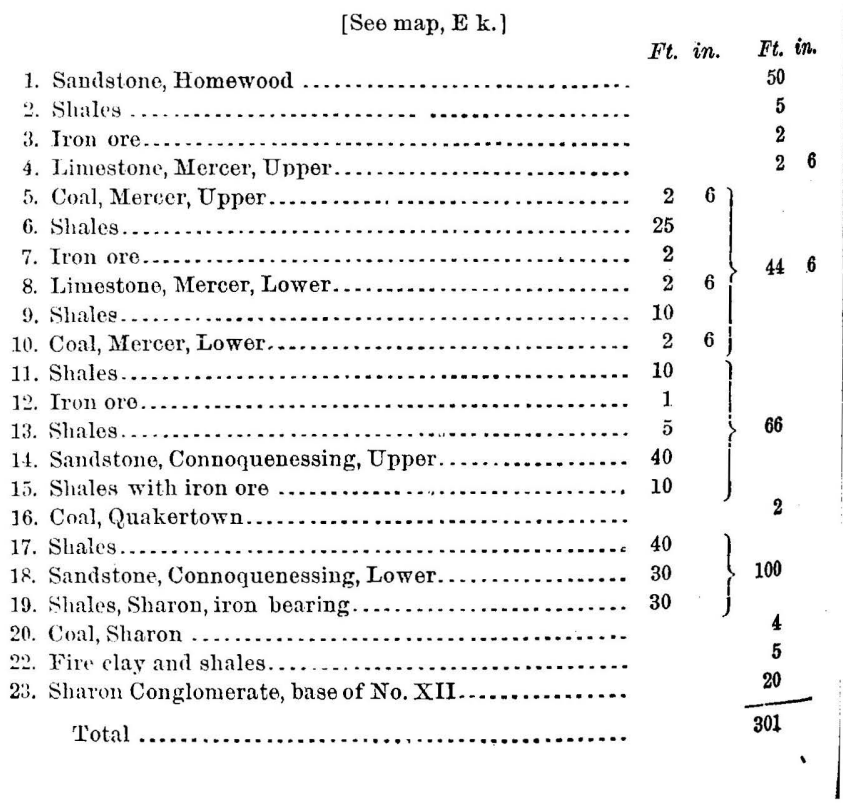


Section near Quakertow, Mahoning County, Ohio.-Where the Ohio. Pennsylvania State line crosses the Mahoning River, near Quakertown, these beds exhibit the following structure (Fig. 141):

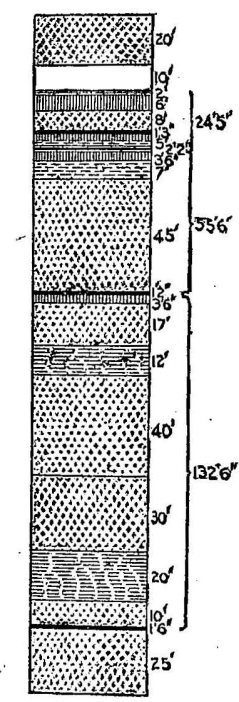

FTG. 141.-Section nea Quakertown, Ohio.
Ohio-Pennsylvania line on Mahoning River.

$$
\text { -[Śeo map, F k.] }
$$

Ft. in. "Fit.' in.

2. Concealed........................................... $\quad \begin{array}{r}20 \\ 10\end{array}$

3. Limestone, पpper Mercer ........................ 2

4. Fire clay

5. Sandstone, shaly ...................................

6. Coal, slaty, Middle Mercer .

7. Fire clay and sandy shales..........................

8. Limestone, Lower Mercer

9. Shales

10. Coal, Mercer, Lower

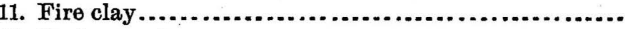

12. Shales, sandy.

13. Sandstone, Connoquenessing, Jpper ..................

14. Coal, Quakertown......................................

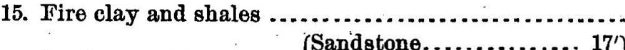

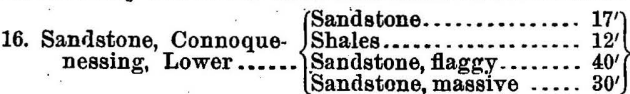

17. Blue shales, with iron ore balls .....................

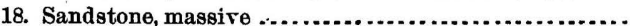

19. Coal, Sharon, and bituminous slate...................

20. Sandstone, flaggy, to base of No. XII.

Total.

The Sharou coal of these sections $(140,141)$ represents the New River coal group of West Virginia, since the Mercer group above does not furnish valuable coal in that region, but only thin slaty beds.

Section in Holmes County, Ohio.-In Holmes County, Ohio, these beds are given as follows (Fig. 142), in Vol. V, Ohio Geology, p. 837 :

Holmes County, Ohio.

$$
\text { [See map, H }
$$

1. Interval, sandstone and shales.

2. Limestone, Lower Mercer....

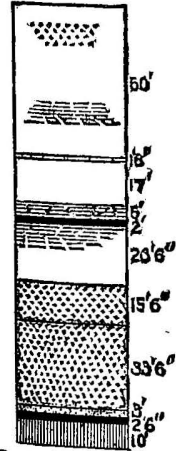

3. Coal, Lower Mercer

4. Concealed

(1)

5. Gray shales.................................................... 6

6. Coal ......................................................... 2

7. Gray shale and concealed......................................... $23 \quad 6$

8. Sandstone, Upper Connoquenessing ............................. 156

9. Coal, Quakertown..............................................blossom

10. Sandstone, shaly, Lower Connoquenessing....................... $33 \quad 6$

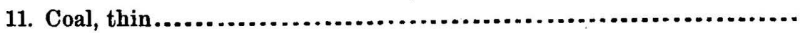

12. Sandstone .................................................... 3

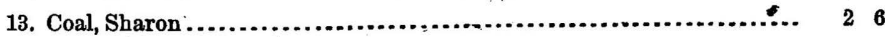

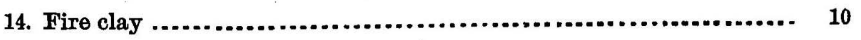

15. Lower Carboniferous beds. 
Section in Washington County, Ohio.-In Washington County, Ohio, the Pottsville measures are given as follows (Fig. 143) by Mr. F. W. Minshall, from the record of the Epler oil boring:

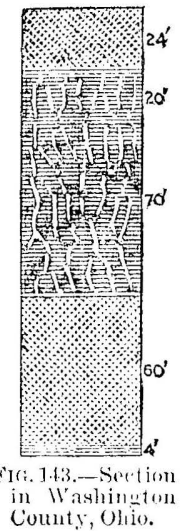

Epler oil boring, Washington County, Ohio.

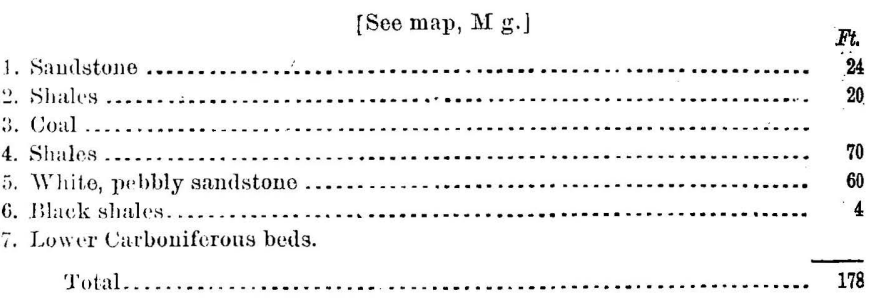

Section at Parkersburg, West Virginia.-The Camden Consolidated Oil Company, in boring at Parkersburg; West Virginia, found the following structure (Fig. 144), according to Mr. R. A. Cole, the superiutendent:

I'arliersburg, West Virginia (boring).

[See map, Of.]

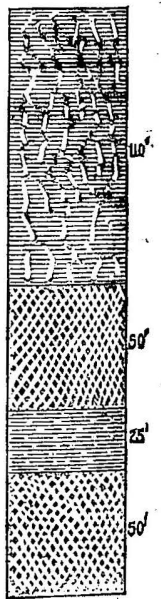

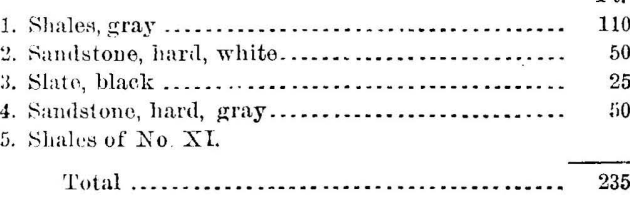

Scctim near Burning Springs, West Virginia.-Near Burning Springs, Wirt County, West Virginia, these same beds have this succession (Fig. 145), as found in the Simpson oil boring by Mr. Minshall:

Simpon well, Wirt County, West Firginia.

$$
\text { [See map, P g.] }
$$

Fig. 144.-Section
under Parkersburg, W. Va.

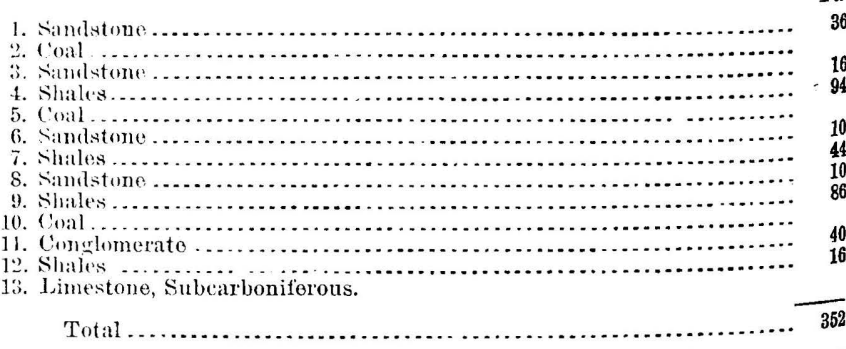

The Burning Springs section (Fig. 145) shows a rapid increase in the thickness of these beds towards the southeast, since they are just twice as thick here as in

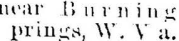
Washington County, Ohio (Section 143), 50 miles distant. 
Nection near Jackson Furnace, Jacksōn Bounty, Ohio.-In Jackson County, Ohio, the Pottsville series has the following structure (Fig.

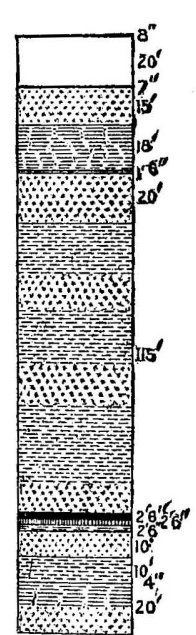

Fig. 146.-Section near Jackson Fur. nace, $\mathrm{J}$ a c k s o County, Ohio.

146) near Jackson furnace, as given in the Ohio Geological Survey, 1870 (p. 158) :

\section{Jackson Furnace, Jackson County, Ohio.}

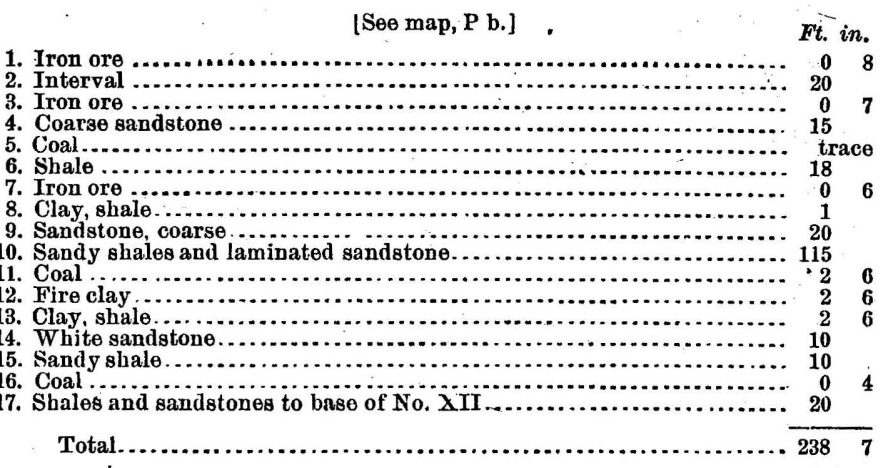

Section at Hanging Rock, Sciota County, Ohio._-In the vicinity of Hanging Rock, Ohio, the Pottsville series has the following structure (Fig. 147):

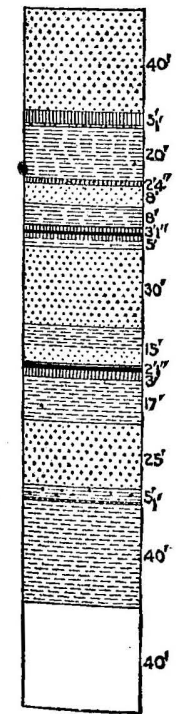

Fig. 147. - Section at Hanging Rock, Sciotal County,

\section{Hanging Rock, Sciota County, Ohio.}

[See map, $\mathbf{R}$ a.]

\begin{tabular}{rr}
$F t . i n$. \\
40 \\
5 \\
1 \\
20 \\
0 & 4 \\
2 & \\
8 \\
8 & \\
3 & 1 \\
5 & \\
30 & \\
15 & \\
8 & 1 \\
3 & \\
17 & \\
25 & \\
5 & \\
1 & \\
40 \\
40 \\
\hline 270 & 6
\end{tabular}

Here the Mercer group, together with the Quakertown coal, is distinctly recognizable at the very southern border of Ohio, while the Connoquenessing sandstones and the dark blue Sharon iron-bearing shales below look exactly like the same beds in eastern Ohio. The base of the series was given me here from the record of a bore-hole put down by Mr. E. B. Willard, superintendent of the Hanging Rock Coal Company.

Bull 65 13 
Section on Big Sandy River, Lawrence County, Kentucky.-.Twenty miles up the Big Sandy River, and near the mouth of Blaine Oreek, the succession of the series is as follows (Fig. 148) according to \begin{tabular}{ll}
\hline ss $^{\prime}$ & the record of Rigdon gas well No.2, as furnished by Mr. \\
F. H. Oliphant:
\end{tabular}

Under Big Sandy River at mouth of Blaine Creek (boring).

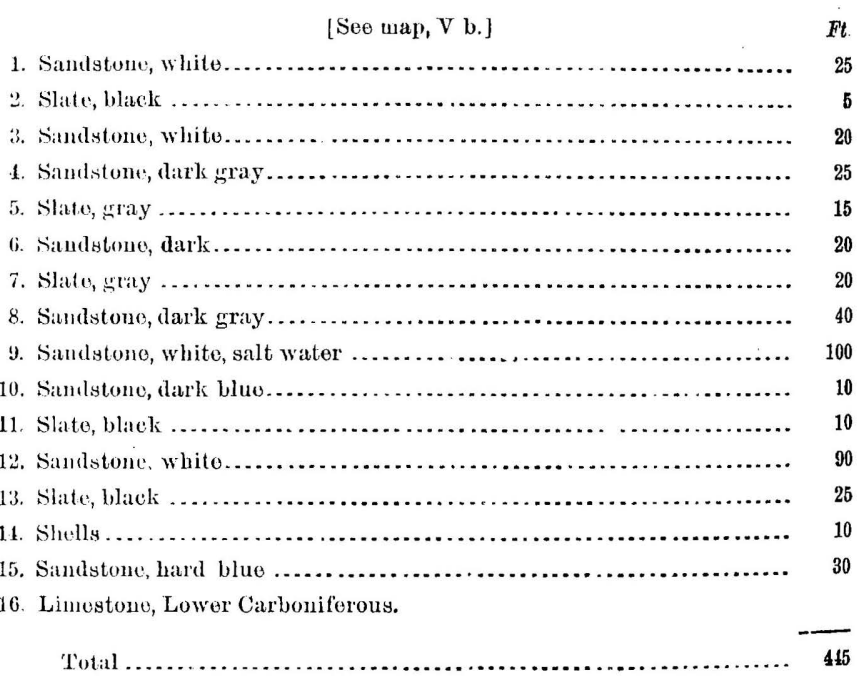

This section exhibits the beginning of the great sonth. oasteru thickening of the Pottsville series along the Big Sandy, bnt we have not sufficient data southward from Blaine Creek to trace the rate of increase along the Tug Fork, since even the top of the Pottsville does not rise to daylight on that stream for 100 miles above the mouth of Blaine. When the bottom series does finally come to the surface at the southern edge of McDowell County, of Blitine Crevk. West Virginia, it is not less than 1,500 feet thick, and may possibly be 2,000, since the Kentucky geologists claim the latter thickness for these measures on the headwaters of the Big Sandy.

There is no point aloug the Tug hiver in West Virginia where a vertical measurement can be made; hence, if the exact thickness is ever determined it must be by a boring.

The black slates, Nos. 2, 11, and 13 of the above section, probably represent the interconglomerate coal beds. 
Section under Charleston, Kanawha County, West Virginia.-On the Great Kanawha River some recent borings for gas have supplied the necessary data there, thus giving measurements at two

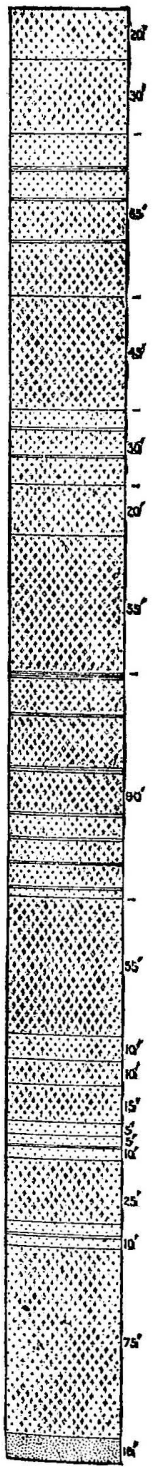
points before the whole formation comes to the surface. The first one of these is the record of the Edwards gas well No. 3, bored at Charleston, West Virginia, which gives the following structure (Fig. 149) for these beds, according to Mr. William S. Edwards :

Under Charleston, Kanawha County, West Virginia (boring).

[See map, T f.]

1. Sandstone

2. White sandstone............................................. 30

3. Hard sandstone and shells.................................. 65

4. White sandstone............................................. 45

5. Black sandstone and shells..................................... 30

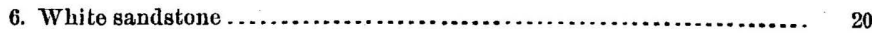

7. Hard sandstone................................................... 55

8. Hard black shells and gas....................................... 90

9. White sandstone........................................... 55

10. Black sandstone.......................................... 10

11. White sandstone........................................... 10

12. Black sandstone.......................................... 15

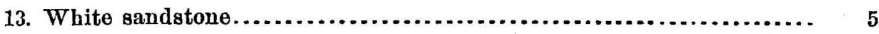

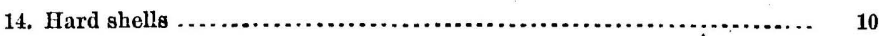

15. White sandstone............................................... 25

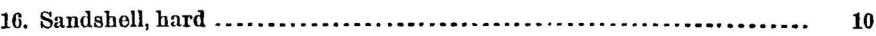

17. White sandstone.......................................... 75

18. Black sand............................................... 10

19. Lower Carboniferous limestone.

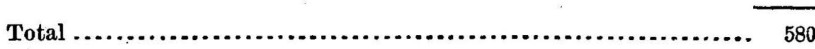

Here the Pottsville series has thickened to about three times its size at the northwestern outcrop of these beds in Ohio, 100 miles distant. Whether the thickening is gradual or abrupt is not known, and can not be until more borings are made. It is probably gradual from the center of the great Apalachian trough, 50 miles northwest of Charleston.

The interconglomerate coal beds appear to be entirely Fig. 149-Section un. absent from the above section, since not even black Kanawlia County, slates are present according to the driller's record. 
Section at Burning Spring, Kanawha County, West Virginia.-At Burning Spring, 9 miles south from Charleston, the record of Edwards gas

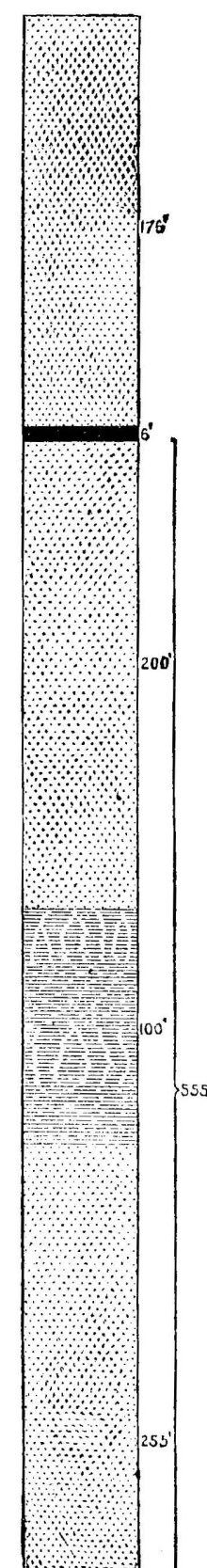

Fla, 150.-_Section at Burninir spring Kauarba County, W. Via. level. quire?.
Burning Spring, Fanawha County, I'est Tirginia (boring):

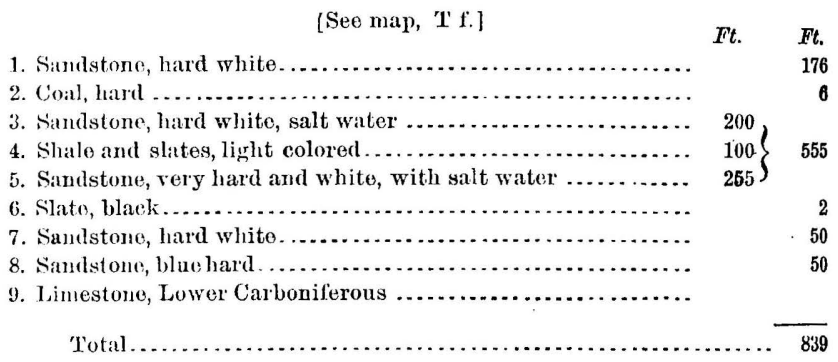

No. 2 represents the Mercer coal group, though no coal thick enough to mine ever occurs at this horizon to the southward, where these beds rise above water

The New River coals belong in Nos. 4 and 6 of the section, but they here contain no coal whatever, though only 40 miles north from the New River coal field.

The series has here increased 259 feet in thickness in 9 miles, a very rapid rate, and possibly indicating that the great thickness ( 580 feet) found under Charleston may have been abruptly instead of gradually ac:

In this boring a considerable flow of natural gas was obtained in the top of the Pocono sandstone, or "Big Injun" oil sand, at a depth of about 1,000 feet. This is the locality where natural gas was first used for manufacturing purposes in the United States, as

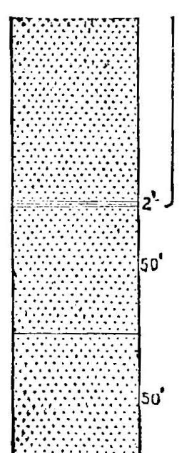
far back as 1841. It was utilized for evaporating salt water. One of the gas wells found here, according to report, displaced for fuel 2,000 bushels of coal daily during a period of ten years. The last well, however (bored in 1887), does not produce much over 500,000 cubic feet of gas daily. The most productive wells were situated near the crest of the anticline which crosses the Kanawha River at Burning Spring. 
Section near Nuttallburg, Fayette County, West Virginia.-Passing on southward up the Kanawha and New Rivers, there is no opportunity

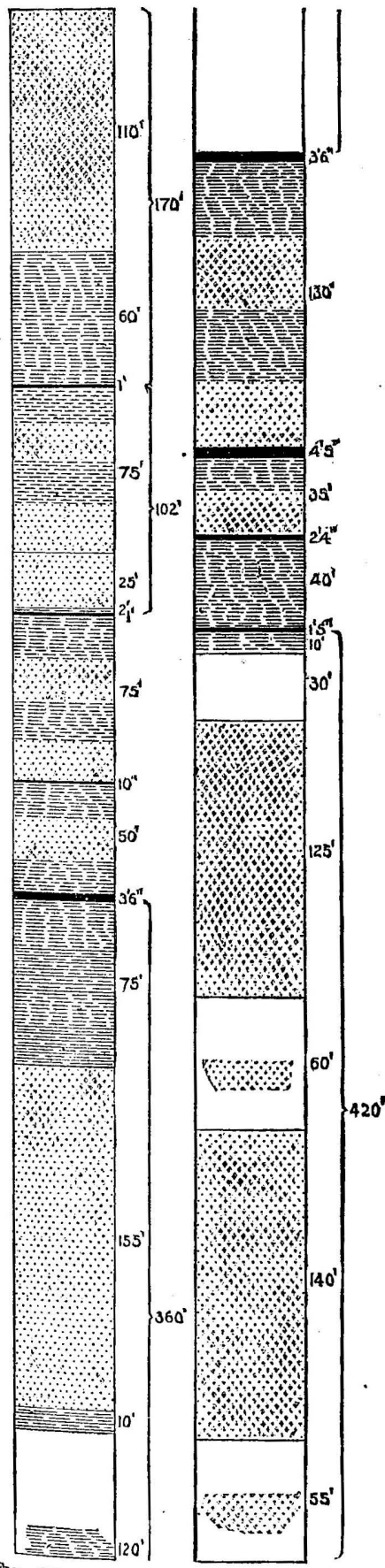

FTG. 151.-Section in vicinity of Nuttall. burg, Fayette Counly, W. Va. to get another measurement of the Pottsville series until all of its members have risen above tle level of New River, in the vicinity of Nuttallburg, Fayette County, West Virginia, 50 miles distant from Burning Spring, where the following succession occurs (Fig. 151) :

Vicinity of Nuttallburg, Fayette County, West Virginia.

[Sce nap, U b.]

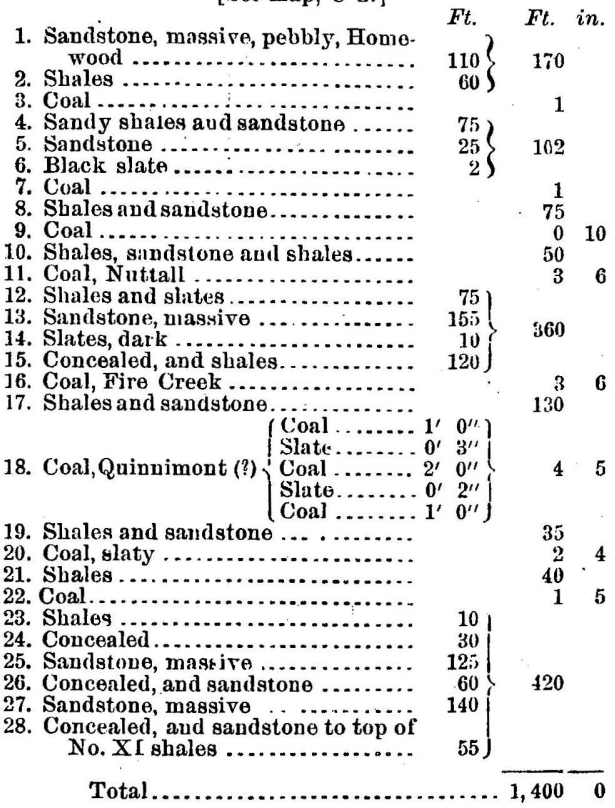

No.11, the Nuttall coal, is the highest member of the New River group that ever furnishes valuable coal along that stream. Its place in the Pottsville series is 400 feet below the top, and the other thin coals above it belong to the Mercer group.

Whether No. 18 is identical with the Quinnimont, or whether this latter coal is the same as the Fire Creek, No. 16, are questions yet unsettled.

Just what represents the Pocahontas coal of McDowell and Mercer Counties in this section, or whether it is represented at all is uncertain, but No. 18 may possibly come at that horizon. 
Section on Crane Creek, Mercer County, West Virginia.-At the extreme sonthern elge of the Appalachian field in Mercer County, West
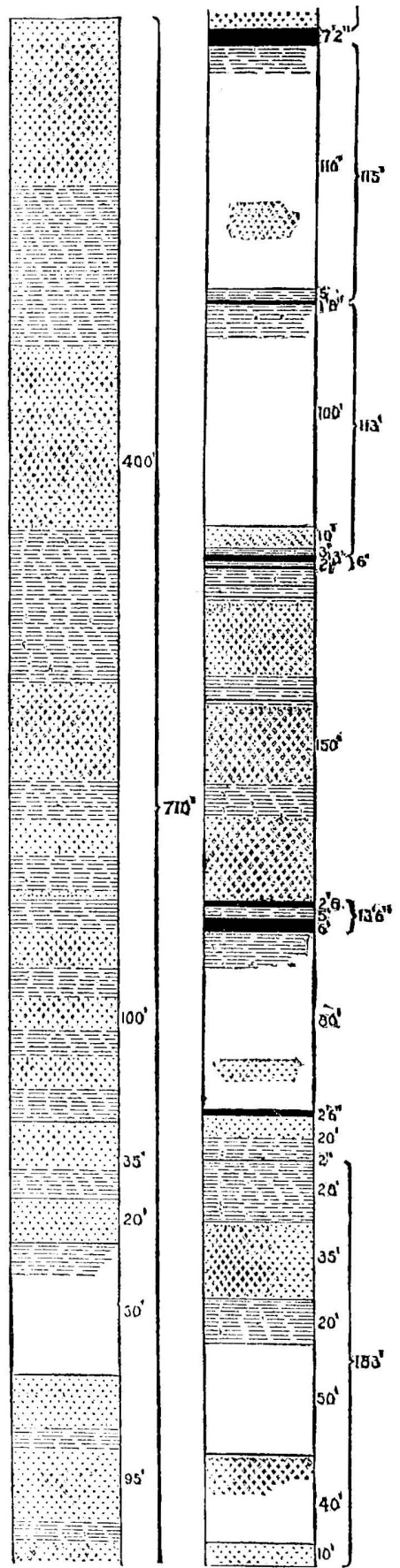

Virginia, the following section (Fig. 152) of the Pottsville series was obtained upon the waters of Crane Creek by add. ing 400 feet to the summit of the column for the estimated thickness of berls re. moved by erosion :

Crane Creck, Mercer County, West Virginia.

$$
\text { [See map, } \mathrm{Y} \text { g.] Ft. Ft. in. }
$$

1. Sandstones and shales, horo eroded from top of No. XII (estimated) $\ldots \ldots \ldots \ldots \ldots \ldots .400$
Shales and sandstones.................. 100

2. Shales and sandstones..................

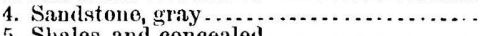

5. Shales, and concealed

6. Sandstone, massive, and shales........... 95

(Coal............ $0^{\prime} 2^{\prime \prime}$

7. Coal Shales.........2. $2^{\prime} \mathbf{6}^{\prime \prime}$

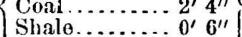
Shale.......... $0^{\prime}$
Coal...........

8. Shales, sandstone, and concealed......... 110$\} 115$

9. Shales .................................... $\left.55_{5}\right\} 115$

10. Coal, good ............................

11. Shales, and concealed.................. 10

12. Sandstone $\ldots \ldots \ldots \ldots \ldots \ldots \ldots \ldots \ldots \ldots, 10,113$

13. Shale ............................... 3$\}$

14. Coal ............ $\left\{\begin{array}{l}\text { Coal } \ldots \ldots \ldots \ldots . . .3^{\prime} \\ \text { Shale } \ldots \ldots \ldots \ldots . .2 \\ \text { Chal }\end{array}\right\} \quad 6$

15. Concealed, with shales, sandstones, and two thin coals ......................... 150

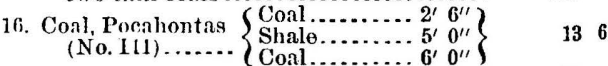

17. Shales, sondstone, and concealed..........

18. Coal (No. II) .

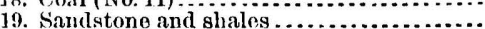

20. Coal (No. I) ..............................

21. Shales ...................................

22. Santstone, gray

23. Shales, dark

24. Concenled .

25. Sandstone, and concealed ................

26. Sandstone, gray, massive................

27. Green, limy, fossiliferous shales, top of Lower Carboniferous.

Total.

The interval adled to the top of the Pottsrille in this section is only an estimate at best, and the amount may not be near large enough, since the Kentucky geologists report the series as 2,000 feet thick not many miles south. west from this region.

The separate coal beds of this section can not yet be satisfactorily correlated with those on New River (Section 151). At one time the writer was inclined to believe that No. 7 might be the equira. lent of the Nuttall vein, and that No.16 of this section was probably identical with No. 18 of the Nuttallburg section 
(151), but the Pocahontas coal lies 200 feet nearer the base of the Pottsville series than No. 18 does on New River, and hence unless this part of the series thins away towards the southwest, which seems improbable, the possibility of identity is rather slender. The mining operations of the next few years, however, may be depended upon to settle the question, since it has a more than scientific interest.

A cursory examination of the sections given will show that the Pottsville series generally has something like the following structure:

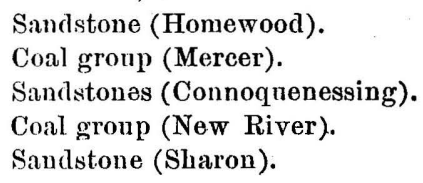

Of course when the series attains such an excessive thickness as on the New River, for instance, the structure is more complicated than the above scheme would indicate, and yet even then a general agreement can usually be made out.

Having now glanced at the general structure of these measures, we shall take up the more important members and describe them in detail.

\section{CHARACTERISTIC HOREONS.}

THE HOMEWOOD SANDSTONE.

The Pottsville series is nearly everywhere capped with a coarse sandstone, which is quite different in texture and general appearance from any of the sandstones in the Coal Measures above. In the vicinity of Homewood, Beaver County, Pennsylvania, this rock attains a thickness of 150 feet, and was named from that locality. It is gcierally quite massive, making great cliffs along the streams and covering the summits with huge blocks arranged in "rock cities." While usually quite hard, it generally splits well and makes excellent building stone, the blocks from it being almost indestructible. Although generally of a yellowish or buftish gray tinge, it occasionally consists of almost pure white quartz grains, and hence sometimes supplies glass sand of excellent quality. This might be called the "cascade" member of the Pottsville series, since it so often produces water-falls.

In Pennsylvania it is generally 30 to 50 feet thick, but occasionally, as at IIomewood and other points, it thickens up to 75 or even 150 feet.

Westward, in Uhio, the rock thins down and is often only 15 to 20 feet thick, but still distinctly recognizable as a heavy bedded, coarse sandstone, filled with fossil stems and trunks of trees, mostly lepillodendron and sigillaria. It is seen in the bed of Little Beaver near its mouth, and frequently between that point and Fredericktown. It is the quarry rock in Coshocton County referred to in Vol. V (p. 104), Ohio Geology, where it is $\mathbf{3 0}$ feet thick and of the same type so often found in Pennsylvania. From this point on across Ohio, to Ironton and 
Hanging Rock, it is frequently seen, and at the latter point makes one of the great cliffs in the steop hillside which gave name to the place, being there 40 feet thick.

Along the Great Kanawha this rock comes to water level at the month of Armstrong Creek, and from there on up that stream, as well as up the New and Gauley rivers, is a great cliff rock 150 to 200 feet thick. It crowns the walls of the New River cañon at Hawk's Nest and other points to Nuttallburg and beyond, where it seems to change suddenly in character sonthward from that, becoming soft and easily disintegrating to a heap of coarse, brown saud.

On the Tug fork of Big Sandy this stratum makes great cliffs along the hills throngh the "ronghs" of Tug, and sinks below that stream at the mouth of Ben's Creek, 95 miles above Louisa.

Ohio Pyle Falls, on the Youghiogheny River, is made by this rock, and the upper portions of the great cascales on the Black Water and Glaty forks of Cheat pour over the same stratum.

It is the gas-bearing member in western Pennsylvania and northern West Virginia.

$$
\text { THE MERCFR GROUP. }
$$

In western Pennsylvania a group of coals associated with two fossiliferous limestones makes its appearánce directly under the Homewood sandstone, and extends almost minterruptedly across the Ohio field to Hanging Rock. It was first fully described from the vicinity of Mercer, Pennsylvania, and named from that locality. When well developed the group presents the succession seen in Section 140 , and is 40 to 50 feet thick.

The two limestones are very much alike, except the Lower Mercer is a little darker blue than the Upper, and is the more persistent. Both are crowded with fossils and are freqnently cherty, some of the famous "flint ledges" of Ohio being mate by one of these beds. Lach limestone usually carries an iron ore on its top of the variety known as "block" ore. The Upper Mercer is known as the Zoar limestone in many portions of Ohio, and its ore is called by several terms, among which are "Dunkel Block," "Franklin Block," "Main Block," "Big Red Block," ete. The Lower Mercer was formerly known as the "Blue" limestone, and its corresponding ore as the "Blne Limestone Block," "Tittle Block," etc.

The Mercer coals are generally two, the npper one coming under the Uprer Mercer limestone and the lower one under the Lower Mercer limestone. Occasionally there is also a coal on top of each limestone, but these beds are sporadie, and hence do not merit a designation, though Orton has applied the name "Tionesta" to the upper one in Ohio, as the writer did in Rejort $Q^{2}$, on Lawrence County, Pennsyl. villia.

These Mercer coals are generally rich in ash, and are seldom mined on a commercial scale, although they are quite persistent from western 
Penusylvania all around the northern margin of the Ohio coal field. Both of them occasionally become cannel in Ohio, the upper being the Strawbridge cannel of Holmes County and the Bedford cannel of Coshocton, according to Orton, while the lower coal is the Flint Ridge cannel of Licking County. Neither of these beds seldom exceeds 3 feet in thickness, and they are more frequently only 1 or 2.

Eastward from Mercer and Lawrence Counties, Pennsylvania, the limestones disappear from this group and the coals thin away, except around the northern rim of the coal field, where, in McKean County, the Alton coal group of Ashburner probably represents the Mercer coals, so that ustrally only one is left, and it is generally quite impure. This bed has received a different name for nearly every locality where it attains workable thickness. Rogers called it the Tionesta coal in Forest County, Pennsylvania, and it is the Mount Savage bed of Somerset. Along the north Potomac River it frequently appears in the cuts of the West.Virginia Central Railroad, and is there known as the "Railroad seam." It has been mined for local use just above Valley Falls, Taylor County, West Virginia, where it lies near water level, and is 4 feet thick, with a slate near center. It always presents a coarse structure, and no first-class fuel is ever obtained at this horizon. Along the New River, and through all the country between it and the Tug Fork, only an insignificant coal, 1 to 2 feet thick, occurs at this level.

The famous Mount Savage fire clay of Penusylvania aud Marylaud comes within the limits of the Mercer group, and directly underlies the Mount Savage coal, which it occasionally replaces.

THE CONNOQUENESSING SANDSTONES.

Below the Mercer group there comes the great sandstone horizon par excellence of the Pottsville series. This group is generally triple, there being a massive sandstone at top, then a coal and shale interval, below which is another massive sandstone. These sandstones were first studied by the writer along the Connoquenessing Kiver, in Lawrence County, Pennsylvania, and they were designated from that stream. The Massillon sandstone of Newberry represents only a portion of the group; otherwise it would have precerence in nomenclature.

Each of these sandstone members is from 40 to 50 feet thick, though occisionally the shale and coal separating them thins out aud they coalesce into one mass 150 to 200 feet thick, or eren more. They are generally quite hard, the quartz grains being finer and more compactly arranged than in the Homewood sandstone above. The color is more frequently jellowish white than any other, though sometimes it is gray.

The Quakertown coal comes between the two sandstone members of the group. It seldom exceeds 2 feet in western Pennsylvania or eastern Ohio, and unless it should be the "Jackson shaft," or "Wellston" coal, it does not seem to attain much importance in that State, though it is often present in the series as a thin bed, being represented in the 
IIanging Rock section (147) by number 13, which is only 2 feet thick, slate and all.

East from the Mahoning River no workable coal is known at this lorizon in Pennsylvania, though a thin coal or black slate is often present.

TIE NEW RIVER COAL GROUP.

The great development of coal in the middle and lower half of the I'ottsville series along New River, West Virginia, has given name to this group. Althongh there are thin representatives of the gronp in nearly every section of the Pottsville which is exposed in Pennsylvania, yet only around the northwestern margin of the field in that State is any valuable coal found at this horizon, namely, the Sharon coal of Mercer Comnty. This bed oceurs in pockets and isolated basins, in the western part of Mercer, where it is 3 to 5 feet thick, and a "block," or open-burning coal of great purity. It enters Ohio in the same patchy condition, and extends through Mahoning, Trumbull, Portage, Summit, Stark, Medina, and Wayne Connties of northeastern Ohio, and it is probably the "Jackson shaft" or "Wellston" seam of Jackson County in sonthern Ohio. In all.cases it is the same open-burning, pure fuel, very low in ash and sulphur.

This Sharon bed and its thin rider appear to represent all the coals in the New River group, and hence it can not be called identical with any one of them, though according to Prof. Fontaine the flora of the Sharon roof shales is very similar to that found in the roof of the Quinnimont bet on New River. These roof shales of the Sharon coal through western Pennsylvania and across Ohio are a very characteristic feature. They begin directly nncler the Connoquenessing sandstones, and are often 40 to 50 feet thick, of a dark blue color, and generally contain much iron ore (carbonate) in nuggets and bands. These shales show the same character at IIanging Rock (Section 147), in sonthern Ohio, as they do on the Mahoning at the east.

In passing sonthward from Pennsylvania, along the Alleghany Mountain region, one of these New River beds thickens up to 3 feet in Garrett County, Maryland, just east from the West Virginia line, and has there been mined for local use on the land of Mr. Browning. It comes near the base of the Pottsville series, is quite soft and pure, and exhibits the same coking type as these coals all do on New River. One of these beds is also workable along Shaver's Fork of Cheat River, east from the Beverly Valley. This coal group, which is well shown in the Black Water section (133) of Tucker Counts, grows in importance south westward throngh Randolph, Webster, Greenbrier and Nicholas Counties, into Fayette, where at Nuttallburg on New River we find the type section of the group (No. 151), which there incloses three workable coal beds besides several too thin to be of economic importance. The three workable beds are, in descending order, the Nuttall, Fire Creek, and Quimnimont, with the intervals separating them shown in Section 151. 


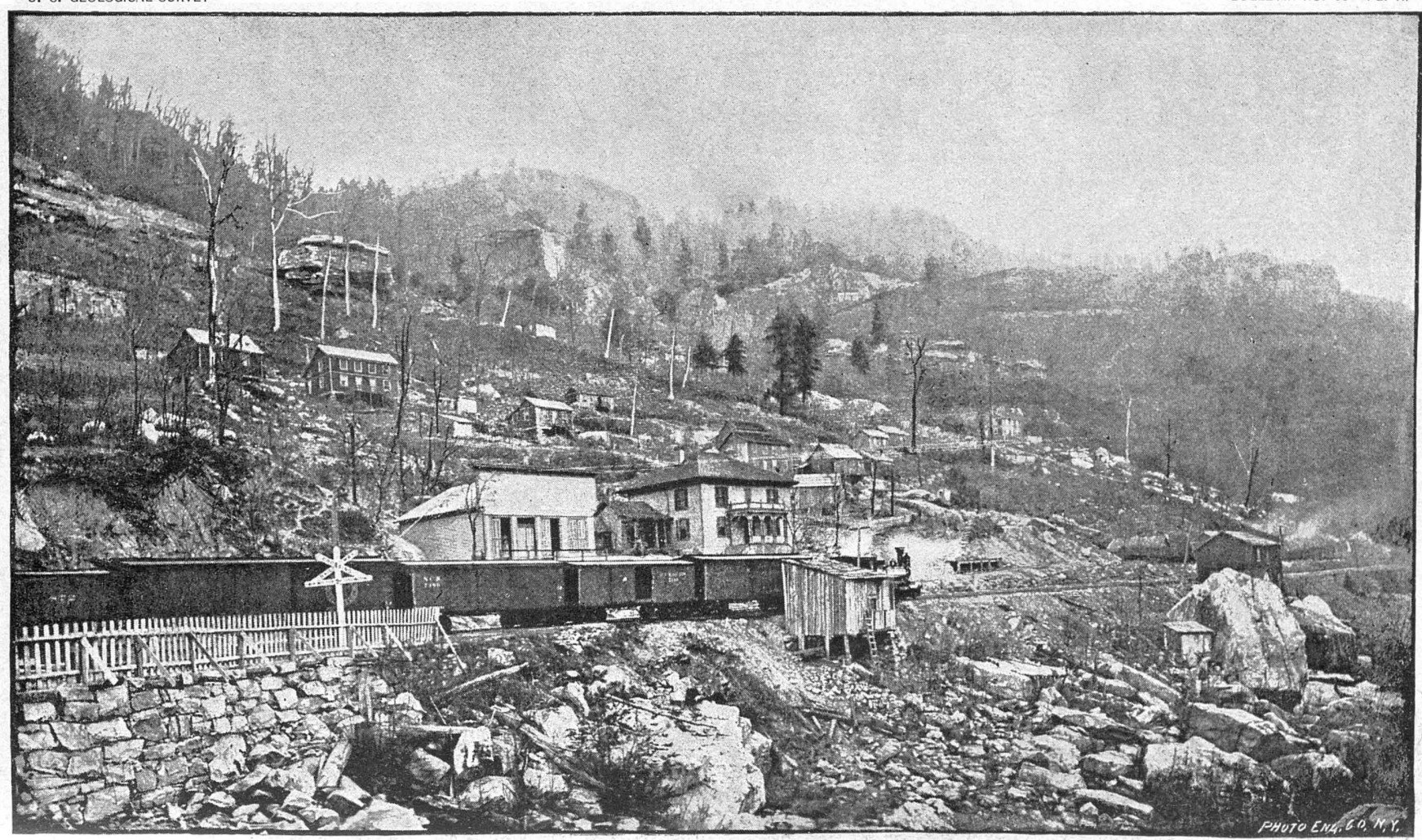

THE POTTSVILLE CONGLOMERATE CLIFFS AND DÉBRIS ON NEW RIVER, WEST VIRGINIA, NEAR FAYETTE. 

These coals vary from 3 to 5 feet in thickness along New River, and are the ones from which the celebrated New River coke is now manufactured. The Nuttall is the most regular and persistent, being the only one which dips below water level at the north with a workable thickness.

They are all quite soft, very low in ash and sulphur, and rich in fixed carbon, making coke of the greatest purity.

The Fire Creek and Quinnimont beds are quite irregular in their distribution and thickness, but both of them furnish much good coal on New River. I have termed the lowest bed the Quinnimont, but the stratigraphical horizon of the Quinnimont seam is not yet settled; since it may prove identical with the Fire Creek bed, but all the coal operators agree that there are three workable coals on New River, and that Nos. 11, 16, and 18 of Section 151 are these three beds, whatever their identity with reference to the Fire Creek and Quinnimont localities may be.

Southwestward from Fayette County towards Raleigh, Mercer, and McDowell, the New River coals still continue to increase in thickness and importance, culminating in the great bed at Pocahontas, in the edge of Virginia.

Section on Crane Creek, West Virginia, near Pocahontas, Virginia.Section 152 shows the succession of these coals on Orane Creek, a tributary of Blue Stone, a few miles northeast from Pocahontas. Here the Pocahontas coal is divided into two benches by a layer of shale 5 feet thick, but at Pocahontas it exhibits the following structure:

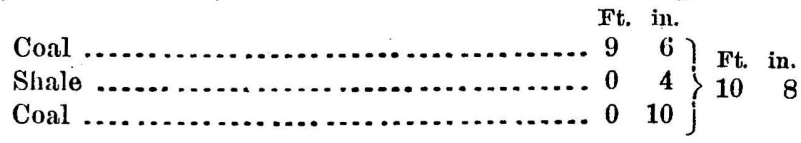

There is a bony streak abont 2 fect below the top of the coal, but it is not rejected in mining:

Section at head of South Elk Horn Creek, McDowell County, West Virginia.-Across the Flat Top Mountain divide from Pocahontas, around the head of South Elk Horn Creek, in McDowell County, this coal exhibits the following structure:

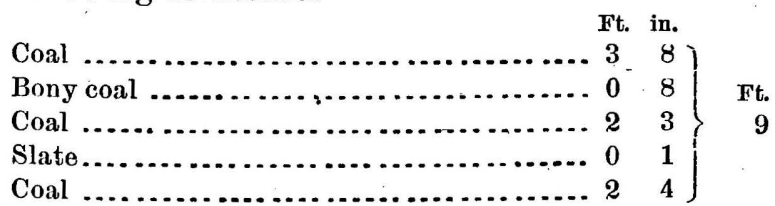

Section on East Branch of Simmons Creek, Mercer County, West Vir. ginia.-On the east branch of Simmons Creek this coal shows as follows:

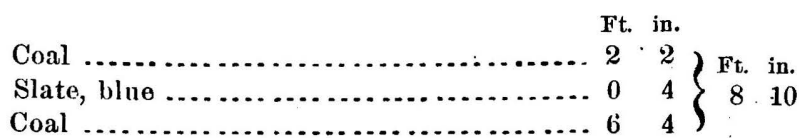


Section on west branch of Flipping Creek, Mercer County, West Virginia.On the Walker tract, west branch of Flipping Creek, the coal has this structure :

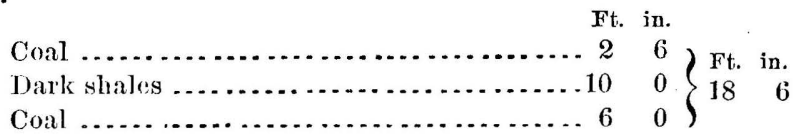

Section on Pinnacle Fork of the Guyandotte River, Wyoming County, West Virginia.-Inst before this coal passes nuder the level of the Pinnacle Fork of the Guyandotte River west from Flat Tol Monntain it exhibits the following structure:

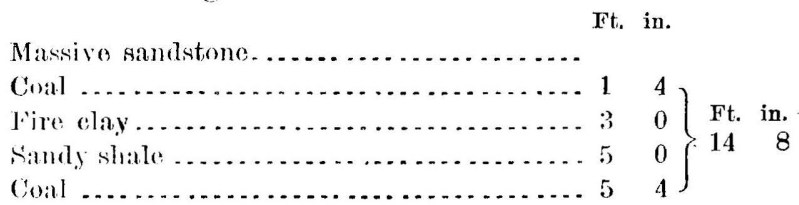

This eoal was numbered III in the original section pnblished from Pocahontas by Maj. Jed. Hotehkiss, and it is frequently known by that name. Major Hotchkiss thinks the Pocahontas bed identical with the Quinnimont of New River, but the writer can not yet satisfactorily correlate this bed with any of the New River coals which have been mined.

The coal from the Pocahontas seam is quite as pure and valuable for coko and general fuel jurposes as any in the New River field, and, in filct, is the same lind of coal.

T'wo other beds of 4 to 5 feet in thickness occur in the hills above the Pocahontas vein, but so far they have not been mined to any extent, as they are not regular in thickness and the great bed below monopolizes the present mining operations.

THE SIIARON CONGIONERATE.

The interval below the Sharon coal in Ohio and western Pennsylvania down to the base of the Pottsville series is often occupied by a massive conglomerate, and when it is absent the coal with its under-clay rests directly on the Lower Carboniferons beds. This conglomerate stratum was consioged a separate member of the series by the Ohio geologists and as representing the entire No. XII conglomerate of Rogers in Pennsylvania.

But later studies have shown that it is simply the basal member of this series. When well developed in Ohio it is very coarse, being a mere mass of pebbles from a pea to an egg in size. There is no single stratum arounl the sontheastern margin of the Appalachian field that will exactly compare with the Sharon conglomerate in physical aspect, though local streaks in all these great sandstones are quite as pebbly, but just as the Sharon coal is represented by several beds in the New liver section, so the sharon conglomerate, only 20 to 40 feet thick in 
Pennsylvania and Ohio, is on New River represented by 300 to 400 feet of shales, sandstones, aud conglomerates.

In northern Penusylvaniathe Olean conglomerate of Bradford County and the Garland conglomerate of Warren have been shown by Mr. John F. Carll to be identical with the Sharon stratum, and they also resemble it very much in physical characters. The coarse type of the Sharon conglomerate appears to be confined to the northwestern rim of the Appalachian field, since it disappears south ward under the other members of the series.

TUE LOWER CARBONIFEROUS BEDS.

Below the base of the Pottsville series come the red shales and limestones of the Mauch Chunk series, and then succeed the gray sandstones of the Pocono, the lowest series of the Carboniferous system.

Thin coals occur locally in both of these members of the Lower Car. boniferous in Penusglvania and West Virginia, but nowhere in these States, nor in Ohio, does any merchantable bituminous coal exist in this portion of the Carboniferous.

The Tipton Run coals of Blair County, Pennsylvania, have been cited . as occurring in the Pocono sandstone series for the last thirty-five years, and this conclusion is reiterated by Mr. Ashburner in a special report male as late as 1855 (Penusylvania Geological Survey, Annual Report, 1885 , p. 250), but a single glance at the fossil plants occurring in the roof shales of the coals now mined there proves that they belong to the Lower Coal Measures, or Alleghany River series, and not to the Pocono, their apparent stratigraphical position being the result of displacement, so that although the Pocono series is reported to contain valuable coal berls in Montgomery County, Virginia, it certainly does not in any of the three States covered by this report, and hence a further consideration of the Lower Carboniferous beds is not germane to this publica. tion. 



\section{N D E X.}

A.

Aleppo Township, Greene County, Pennsylvania, section in ..............

Alleghauy County, Maryland, section iu ..............................

Alleghany County, Pennsylvania, sectious in .................

table showing strata of................

Alton coal group= Mercer coals..........

Ames limestone.........................

Andrews, $\mathrm{E}$. B., section given by ........

Antiquity, Ohio, section at

Arluckle, West Virginia, section at....

Armstrong County, Pennsylvauia, sections in ...........107, 108, 109, 110, 111, 184

Armstrong Creek, West Virginia, section at mouth of .......................

Arno coal ...............................

reologic identifications by.............

Athens County, Ohio, sections in .......66, 133, 134

\section{B.}

Baird Ore, Ohio

Bakerstown coal

Baltimore and

Barbour County, West Virod, section on.

Barclay, Mr., section furnished by........

Baresville, Obio, section at...............

Barnet coal = Mildle Kittanning coal......

Jarren Muasuros or Jik Tiver geries

leaver County, Pennsylvania, section in.

Beaver Liver, Pernsylvania, soction noar nouth of.

Beaver liun, Pennsylvania, section on...

Berlford County, Pounsylvania, sections in ..............................

Bellaire, Ohio, section at................... section near......................

Belltinn, West Virginia, section at .........

Bellton coal group .........................

Benuington, Peunsylvauia, section at....

Ben's Creek, Cambria County, Pennsylva. nil, section at

Berlin, Pennsylvania, section at ..........

Berry's Mino, Morgan County, Ohio, sec tion at.

Big Hurricane Creek, Putnam County, West Virginia, section at .........

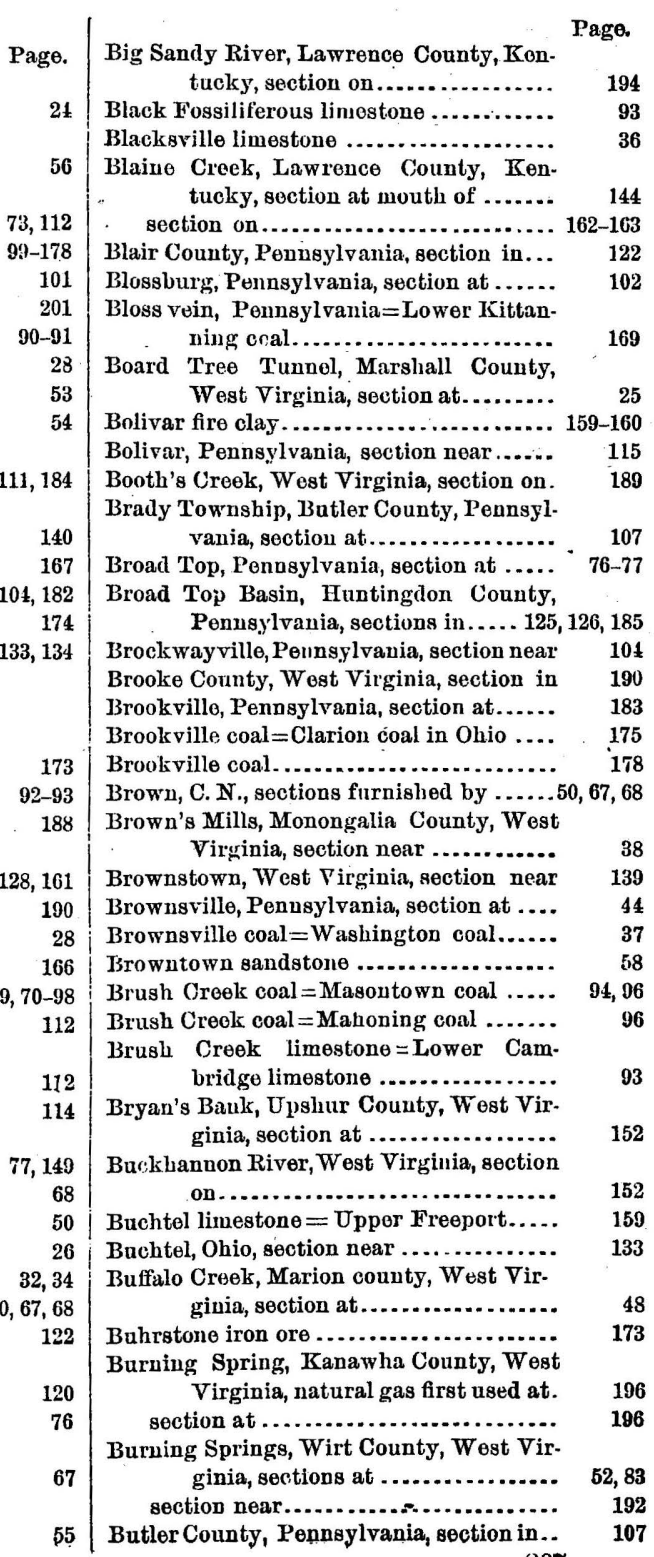




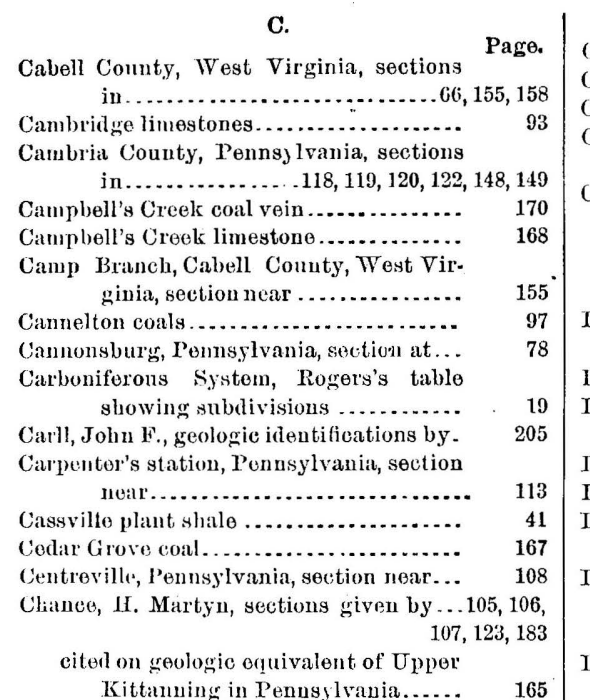
geologic identifications by .......... 175, 178

Chapline Hill, Wheeling, West Virginia, section at .....................

Charleston, West Virginia, section near... sections at. ....................... 136, 195

Cheat River, 'Tueker County, Wost Virginia, sections on............. 187, 188

Clarion coal............................ 175-170

Clarion County, Pennyylvauia, sections in . . . . . . . . . . . . .

Charion sandstone................... 176

Clarkyburgr limestone .................. $\quad 88$

Charksburg, West Virginia, sections at. .48-49, 129,

Clearfiold County, Pennsylvania, sections in ....................... 103, 124, 182

Clearfield, Pennsylvania, sections at. . . 123, 182-183 Ginton coal $=$ = Middle Kittaming coal... 166

Coalburg, West Virrinia, coal beds at .... 96 section at .......................... 162

Coal Valloy gas vein, West Virginia ..... 170

Cole, R. A., sections given by ........... 130, 192

Columbia mine, IVestmoreland County, Penusylvania, section at..........

Coleman limestone....................

Columbiana County, Ohio, section in .....

Colvin's Rum, Greene County, Pennsylvania, section on .

Colvin's Rum limestono

Gonemangh, Pennsylvania, section at ....

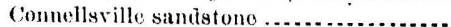

Conoquenessing randstones .............

Cook vein, West Virginia ...............

Copernan'y Knob, West Virginia, section at .

Cove Creek, Wayne County, West Virginia, sections on.............155-156, 157

Craig, Geo., recore of boring furnished by

Crane Creok, Mercer County, West Vir. ginia, sections on
Gresson, Pennsylrania, section at ........

Crinoidal coal........................

Crinoidal limestone ....................

Cucumber Run, Fayette County, Pennsylvania, seetion on ...............

Ciurunt's farm, Upshur County, West Virginia, section at..............

\section{D.}

Dickinson Salt Works, West Virginia, section at .....................

Doubleday, Mr., section furnished by....

Dumbar Creek, Fayette County, Pennsylvania, section at .................

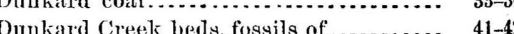

Dunkard Creek, Greene County, Peunsylvania, section on...............

Dunkard Creek series.................19, 20-42

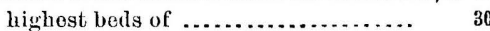

agre of .......................... 41-42

Duukard Creek series. See Permo-Carboniferous.

I.

Eagle limestone...................... 141, 177

Eagle, West Virginia, section at ........ 176

East Brady, Pennsylvania, seotion at.... 106

Elwards, W.S., sections furnished by ... 136, 195

Elk County, Pennsylvania, sections in .. 104, 182

Elk Lick coal ........................... $\quad 89-90$

Elk Lick limestone. ..................... 90

lik Rivor series .................... $70-98$

Elk River, West Virginia, section at mouth of .................... 136

Eplor oil boring, Washington County, Ohio section at................. 192

F.

Fairfax, Knob, West Virginia, section at. section near........................

Fall Brook, Punnsylvania, section at.....

Farmingtol, West Virgiuia, section at...

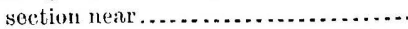

Fayete County, Pennsylvania, sections

in $\ldots \ldots \ldots \ldots \ldots \ldots \ldots \ldots \ldots . .44,74,110$

Fayette County, West Virginia ........ 176, 197

Feleral Creck, ()hio, sectiou at.......... 67

fierriforous limestone................. 173-175

Fire Creek coal .

Fish Greek sandistone...................

Fishinis Creek, Wetzel County, Wost Viryinia, section on.............

Jishpot limestono = Sewickley limestone.

Fleming, Cochran, records of borings furnished by ....... 73,112

Flippins Creek, West Virginia, section on 204

lontaine, W. M., formation named by .... 179

Fossil horizons and localities .....31, 34, 35, 37, 38,

$41,42,57,59,60,62,79,90-91,94$ $97,98,159,163,169,177,179-180$

54

Fossils of the Upper Coal Measures .....

Fussil plant horizons and localities ....34, 35, 37, 38,

41, $42,57,97,169,179-180,205$ 


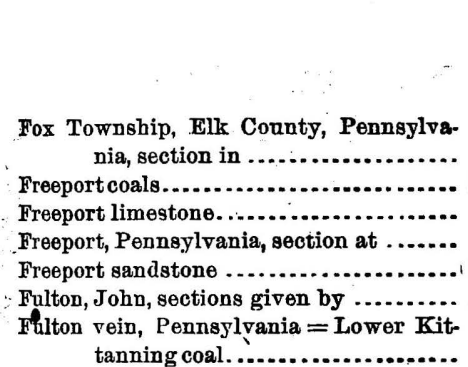

G.

Gallitzin coal = Mahoning coal (?) ....... Gallitzin, Pennsylvania, sections near.... 148-149 Gas (natural) first used for manufacturing purposes at Burning Spring, West Virginia ..........................

Gilboy sandston $\theta=$ Browntown sandstone Gilmer County, West Virginia, section in. Gilmore sandstone

Gladden's Run, Pennsylvania, section on. Gray Ore, Ohio.

"Great" Conglomerate = Pottsville Conglomerate ..........................

"Great" limestone .......................

Greene County, Pennsylvania, sections in $\ldots \ldots \ldots \ldots \ldots \ldots \ldots \ldots \ldots . .22,23,24,45$

Green Fossiliferous limestone ........... 90-91

Guernsey County, Ohio, section in.........

Guyanơotte Mountain, West Virginia, section at .........................

Guyandotte River, West Virginia, sections on ....................... 155, 204

H.

Hacker's Valley post-office, West Virginia, section at ...................

Haggerty, John, sections furnighed by 153

Hanging Rock, Ohio, section at ... 105-106

Harrison County, Obio, section in........ 68

Harrison County, West Virginia, sections in. $\ldots \ldots \ldots \ldots \ldots \ldots \ldots \ldots . \ldots .48,49,129,189$

Hartford City, West Virginia, section at..

Hartley's bank, near Masontown, West $\nabla$ irginia, section at ...............

Hobson coal $=$ Washington coal..........

Hocking Valley, Obio, sections in ........

Hog Hollow coal ==Middle Kittanning coal ......

Holly River, West ${ }^{\prime}$ irginia, section ou...

Holmes Countr, Ohio, section in..........

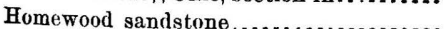

Horton Township, Elk County, Pennsyl. vania, section at.....................

Hostetter coal............................

Hotchkiss, Jed, section given by.

Houtzdale, Pennsylvania, section near...

Hukill, E. M., section furnished by.

Huntingdon County, Pennsylrania, sections in ...................... 125, 18

Huntington, West Virginia, sections at ... $\quad 66,84$ section near.

I.

Indiana County, Pennsylvania, sections in Irondale limestone and ore. Bull. $65-14$

163

111

163-164

169
INDEX.

Page.

18,122

Jackson Furnace, Jackson County, Ohio, section near..............................

Jackson Township, Cambria County, Pennsylvania, section in..........

Jefferson County, Ohio, section in........

Jefferson County, Pennsylvania, section

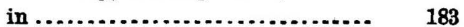

Johnston, John L., section furnished by.. $\quad 49$

Johnstown (Cement) limestone .......... 165-166

Johnstown, Pennsylrania, section at ..... 118

Jollytown coal.......................... 34

Jollytown limestone .................... $\quad 34$

Jordan, Col., record of boring near Charles. ton, West Virginia, furnished by..

\section{$\mathbf{K}$.}

Kanawha Black Flint.................... 98 Kanaw ha County, West Virginia, sections in ...............8 85, 136, 138, $162,195,196$

Karthaus, Pennsylvania, section near.... 103 Kellersburgh, Pennsylvania, section at... 184 Kenova, West Virginia, section near..... 158 Kittanning coals......... 164-165, 166-167, 169-170 Kittanning fire clay .................... 171 Kittanning, Pennsylvania, section near... 109 Kittanning sandstone................ 172

\section{L.}

Laughlintown, Pennsylvania, section near Laurel Run, Westmoreland County, Pennsylvania, section on ............... 116 Lawrence County, Kentucky, sections in 144, 145 $162-163,194$

Leading Creek, Gilmer County, West Vir. ginia, section on ................. 53

Letonia, Ohio, section near ............. 132

Lesley, J. P., Potteville conglomerate named by.

Liberty Township, Washington County, Ohio, section at ............... 29

Lick Run, West Virginia, section at mouth

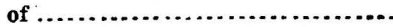

Ligonier, Pennsylvania, section at. ....... Limestone Hill, West Virginia, exposure of limestone at....................

Limestone ore, Ohio.................... 173

Linton, Prof., sections given by ......... 113, 185

Little Beaver Creek, Pennsylvania, section at mouth of.................. 130

Little Clarksburgh coal ................ $\quad 88$

Littie Falls, West Virginia, section at.... 80

Little Kanawha River, West Virginia, section on ..................... 158

Little Lanrel Creek, West Virginia, section on........................ 156

Little Pittsburgh coal................... 88-87 
INDEX.

Little Washington coal.

Little Waynesburg coal.................

Lloyd Wamsley's bank, Upshur County, West Virginia, section at .......... Lockport, Pennsylvania, section near.... Logansport, l'emsylvania, section at. .... Logan County, West Virginia, section in. Lovejoy, E., sections in Ohio furnished by .

Lower Cambridge limeston $\theta=$ Brush Creek limestone.....................

Lower Cambrirge limestone $=$ Philson limestone .........................

Lower Carboniferons beds ..............

Lower Coal Measures . .................19,99-178

Lower Coal Yeasures, table showing strata

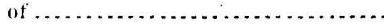

Lower Freeport coal . . . . . . . . . . . . . . . 160 161

Lower Freepert limestone .............. 163

Lower Frerport sundatune...... ....... 163-164

Lower Kittinningr coal . . . . . . . . . . . . . . 169-170

II.

Mahoning coal .......................

Mahoning County, Ohio, section in .....

Mahoning liniestone..................

Mahoninar River, Ohio, section on........

Mahouing siludstones.................95-96,97

Malken, West Virginia, section near...

Maple Swamp water tank, TVest Virginia Central R. R., section at ........

Mapletown coal = Sewickley coal ........

Marietta sandistones..................

Marion County, West Virginia, sections in ..................... $37,48,129,189$

Marshall County, Wost Virginia, sections in ............................

Martin Comnty, Kentucky, section in...

Mason Connty, Weyt Virginia, sections in

Mlasontown, West Virminia, coal bed at..

Masontown, West Virginia, section near.

Missillon samelatone :- Comoruenessing simblatones in part.............

Miluch chumli reil shale, geologic place of.

Me'oy shaft, near Gallitzin. Cambria Comnty. Penusylvamia, sertion at. 148-149

Mecumeville, ()hio, scetion near.........

Mellowell County, West Virginia, soetion in ...........................

Meckurs liun, Athens (ounty, Ohio, section on

Mehatfey, J. A., section on Beaver Run, Ponnsylvania, given by .........

Moigs County, Ohio, rections in.........

Meigs Crek coal = Sewiekley coal.......

MereerConnty, Pennsylvania, sections in.

Mercer County, West Virminia, sections in ...................... $198,203,204$

Mereer «roup .......................... 200-201

Middle Camelton coal.................. $\quad 97$

Middle Freeport coal..................... 160

Mildle Kittanning coal............... 166-167

Miller's Eddy, Pennsylrania, section at.. 105

Mineral County, Wost Virginia, soctions in ......................... 126, 127, 186

Minshall, F. W., sections furnished by.
Moatsville, Barbour County, West Vir ginia, section at................ Monongalia County, West Virginia, sections in .................. $38,46,47,79,80$

Monongabela River series.............. 42-69

Morgantown sandstone ................ $\quad 88-89$

Morgantown, West Virginia, section at .. $\quad \mathbf{8 9}$

Morrisdale, Penusylvania: section near.. 123

Moundsville, West Virgivia, section at... $\quad 51$

Mountain limestone, geologic place of.... 19 .

Mount Equity mine, Bedford County, Pennsylvania .................... 149

Mount Morris limestone ................ $39-40$

Mount Vernon furnace, Ohio, section near 134

Mumble-the-Peg Creek, Nicholas County, West Virginia, sectinn on........ 154

Murraysville, Penusylvania, sections at ............................114, 184-185

Muskingum County, Obio, section in .... 132

N.

Natural gas first used for manufacturing purposes at Burning Spring, West Virginia .......................

$\begin{array}{ll}\text { Nelsonville, Ohio, section near........... } & 134 \\ \text { New Bethlehem, Pennsyl rania, section at. } & 106\end{array}$

Newburg, West Virginia, sections at .... 65, 81, $117,167,170$

New Lisbon, Ohio, section near......... 132

New Martinsville, West Virginia, section

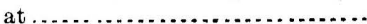

New River coal group................. 202-203

New Straitsville, Ohio, section at....... 168

Nicholas Conuty, West Virginia, sections in ............................. 153, 154

Nineveh coal.......................... 32

Nineveh limestone..................... 32-35

Nineveh sandstone...................

Nuttallhurg, West Virginia, section at... 197

Nuzum's Mill, Marinn County, West Vir.

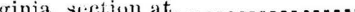

0 .

Oceana, West Virginia, section at........ 143 Ohio County, West Virginia, sections in.. 49, 130 Ohio Geological Survey reports cited .... 28,66, $67,68,132,134,135,161,165,168,178,191,199$

Old Peach Orchard, Lawrence County, Kentucky, section at............. 145

Oliphant, F. H., record of borings given by $\ldots \ldots \ldots \ldots \ldots \ldots \ldots \ldots \ldots \ldots \ldots \ldots \ldots \ldots \ldots 14,145,194$

Ore Hill furnace, section near........... 107

Orton, Edward, strata named by......... 93

beds of lower coal measures traced across Ohio by ................. 101

cited on subdivision of Ferriferous limestone in Ohio ................ 131 soctions given by ................. 134, 135 cited on Ohio equivalent of Upper Kittaning cited on Ohio coal beds............... 158 cited on geologic equivalent of Upper Kittamning in Ohio.............. 165 cited on Middle Kittanning coal in Ohio ............................ geologic identifications by............

\section{n} (n)

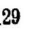

\section{.}

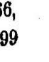
int

\section{.} ,

\section{5.}

:

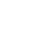

106

32
03 .

45

$$
\text { ind }
$$


$\begin{array}{lr}\text { Panther Hill, Ohio, section at............... } & 134 \\ \text { Parkersburg, West Virginia, sections at. . } & 130,192\end{array}$

$\begin{array}{lr}\text { Parkersburg, West Virginia, sections at. . } & 130,192 \\ \text { Parsons, James, section furnished by .... } & 187\end{array}$

Patton station, Clarion County, Pennsylvania

Peach Orchard coal, geologic place of ..... cited .29, 31, 37, 42, 44, 68, 74, 93, 94, 103, 104 $105,106,107,108,116,120,121,122,123,125$, $126,149,169,173,182,183,184,185,189,190,205$

Permo-Carboniferous or Dunkard Creek series ............................19, 20-42

age of............................... $41-42$

Perry County, Ohio, sections in .......... 133,168

Philippi, West Virginia, section at ...... 161

Philson limestone $=$ Lower Cambridge limestone .......................

Piedmont, West Virginia, sections at..... 126, 186

Pine Creek limestone ...................

Pinkerton Point, Pennsylvania, section at

Pipe Creek, Belmont County, Ohio, section at.

Pittsburgh coal .........................

Pittsburgh coal iron ores ................

Pittsburgh limestones ...................

Pittsburgh, Pennsylvania, section at ....

Pittsburgh region, section in ............

Pittsburgh sandstone .....................

Plant horizons and localities, 34, 35, 37, 38, 41, 42, $57,97,169,179-180,205$

Platt, Franklin, strata named by......... 90 geologic identifications by ............ 91 sections given by..............103, 120, 121, 122

Platt, Messrs., strata named by .......... 63 section furnished by .................. 76 geologic identifications by........... 89, 164 cited on geolozic place of Johnstown Cement limestone..................

Platt, Wm. G., sections given by .. 104, 108, 115, 184 Pocahontas, West Virginia, section near. Pocono sandstone, geologic place of.......

Pomeroy, Meigs County, Ohio, section at

Porter's (Greene), Twelve Pole Creek, West Virginia, section at ........

Posten's bank, near Masontown, West Virginia, section near............

Pottsville Conglomerate series.........19, 179-205

Pottsville series, structure of ........... 199

Powell Mountain, West Virginia, section at.

Preston Cuunty, West Virginia, sections in $117,150,167$

Putnam County, West Virginia, sections in $\quad 55,56$ Putneyville, Pennsylvania, section at .... $\quad 108$

Q.

Quakertown, Ohio, section near........... Quakertown coal.

Quinniunont coal

R.

Raleigh County, West Virginia, section in Randolph County, West Virginia, section in

142

151
Raymond City, West Virginia ............

Redstone coal .............................

Redstone limestone ........................

Red shale beds.

Rice's Landing, Pennsylvania, section at.

Richmond, Pennsylvania, section near...

"Ridge" limestone, West Virginia .......

Ritchie County, West Virginia, section in

Roaring Creek coal vein, West Virginia.

Robinson's Run, Monongalia County,

West Virginia, section at ........

Rock Point coal=Middle Kittanning coal Rogers Brothers, strata named by ........

Rogers, H. D., strata named by .......43, 59, 63, 14i section given by .................. 103

Rogers's subdivision of the Carboniferous 18-19

Rowlesburg, West Virginia, section near 188

\section{S.}

Sawpit branch of Cove Creek, West Virginia, section on ...................

Scioto County, Ohio, sections in ..... 134, 193

Scott's Run, Monongalia County, West Virginia, section at ..............

Scrub-grass coal=Upper Clarion coal ....

Selby, A. G., section near Huntington, West Virginia, furnished by .....

Seral conglomerate $=$ Pottsville conglom erate ............................

Sewickley sandstone....................

Sewickley coal ..........................

Sewickley limestone....................

Serickley, Penngylvania sections at ... 73,11 ?

Shade Creek, Ohio, sections at........... 66

Sharon coal ............................ 202

Sharon couglomerate..................... 204-205

Shawnee limestone $=$ Upper Freeport ... 159

Shawnee, Ohio, section near.............. 133

Shough's Knob, Greene County, Pennsylvania, highest Dunkard beds at..

Shoup's Run, Huntingdon Count, , Pennsylvania, section at ..............

Shumard, G. F., section furnished by ....

Simmons Creek, West Virginia .......... 203

Simpson well, Wirt County, West Virginia, section................... 192

Sims, H. N., section given by............ 125

Somerset County, Pennsylvania, sections in $\ldots \ldots \ldots \ldots \ldots \ldots \ldots \ldots \ldots \ldots \ldots \ldots . . .121,186$

South Elk Horn Creek, West Virginia, section on ........................ 203

Sprucevale, Ohio, section near............ 131

Steele, John L., section furnished by..... 189

Sterling mines near Houtzdale, Pennsylvania, section at .................. 124

Steubenville, Ohio, section at............ $\quad 77$

Stevenson, John J., strata named by .......31, 32, 33 $34,36,37,39,59,62,88,93$ sections given by .....44, 68, 74, 116, 126, 149, 159 Stevenson, Wm. S., sections given by ...78, 153, 185 Stone Coal Run, Upshur County, West Virginia, section at .............. 151

Stony Creek, Somerset County, Pennsylvania, section on

121 
Stoyestown, Pennsylvania, section at..... Stroud Creek, West Virginia, section on.. Sugar Camp Hollow, West Virginia, section in.

Summit limestone $=$ Mahoning limestone Summit limestone $=$ Upper Freeport .....

$\mathbf{T}$.

Taylor County, West Virginia, sections in. 128,189

Taylorstown, Pennsylvania, section near.

Thomas, West Virginia, section near.....

Tioga County, Pennsylvania, sections in 102,103

Tionesta coal $=$ Upper Mercer coal ..... 200-201

Tipton Run coals, geologic place of...... 205

Trimble coal .......................... 167

Trough Creok, West Virginia,sections on.

Tucker County, West Virginia, sections

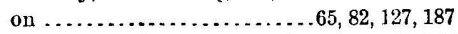

Tug Fork of Big Sandy River, sections on. 146, 147

Twelve Pole Creek, West Virginia, sec. tions on .................... 156, 158

Tygart's Valley River, section on ....... $\quad 128$

\section{U.}

Uniontown coal

Tniontow sandstone

Upper Cannelton coal..................

Upper coal measures or Mlonongahela River series..................19, 42-69 table of beds of ................

Upper Freeport coal.................. 147-148

Tpper Freeport limestone............... $\quad 159$

Upper Freeport sandstone............. 160

Upper Kittanning coal................. 164

Upshur County, West Virginia, sections in .......................... 151, 152

$\nabla$.

Valley Falls, West Virginia, section at ..

W.

Wall, J. Sutton, section near Webster, Pennsylvania, furnished by.....

Warfield coal, West Virginia ...........

Warfield, Kentucky, section at.........

Washington "A" coral .................

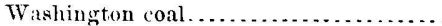

Washington County, Ohio, suctions in ...29, 52, 192

68

Washington, County, Pennsylvania, seo-

Paga

9

W

tions in . . ..............29, 45, 78, 113, 185

Washington limestone................. 35,36

Washington, Pennsylvania, sections at.29, 77-78

113,185

Washington sandstone............... 38-39

Wayne County, West Virginia, sections in.155, 156

157, 158

Waynesburg "A" coal ................ 39

Waynesburg "B" coal................. $\quad 39$

Waynesburg coal .................... $\quad 57$

Waynesburg limestone ................. 58

Waynesburg sandstone ................. 40,41

Webster County, West Virgiuia, section in $\quad 153$

Webster, Pennsylvania, section near.... $\quad 68$

Wellersburg, Pennsylvania, section near. $\quad 186$

Westernport sandstone ................. $\quad 59$

Weller coal $=$ Crinoidal coal ........... 99

Wellsburg, West Virginia, section at.... 190

West Brownsville, Pennsylvania, seotion

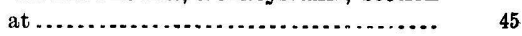

Westernport, Maryland, sections near..56, 126, 186

Westmoreland County, Pennsylvania, sec-

tions in .................44, 68, 113, 114, 116, 185

West Virginia Central Railroad, sections

on .................................. 127

59 West Virginia and Pittsburgh Railroad,

section on......................... 152

Wetzel County, West Virginia, sections in 27,38

Wheeliug Creek, Pennsylvania, section on 24

Wheeling, West Virginia, sections at.... $\quad 130$

Willard, E. B., record of boring furnished

by ............................. 193

Willey fork of Fishing Creek, Wetzel

County, West Virginia, sections on..... 38

Wilson's mine, Randolph Count.y, West

$\nabla$ irginia, section at.................. 151

Wiudy Gap coal ...................... 31

Wiudy Gap limestone................. 30-31

Winfield, West Virginia, section at......

Winifrede, West Virginia, sections at .... 162

Wirt County, West Virginia, sections in 52, 83, 192

Wise, West Viruinia, exposure at ........

Wood County, West Virginia, sections in . 130, 192

Wyoming County, West Virginia, sections

in .............................. 143, 204

Z.

Zaresville, Ohio, section near ............

Zoar limestone $=$ Upper Mercer limestone
132

200 







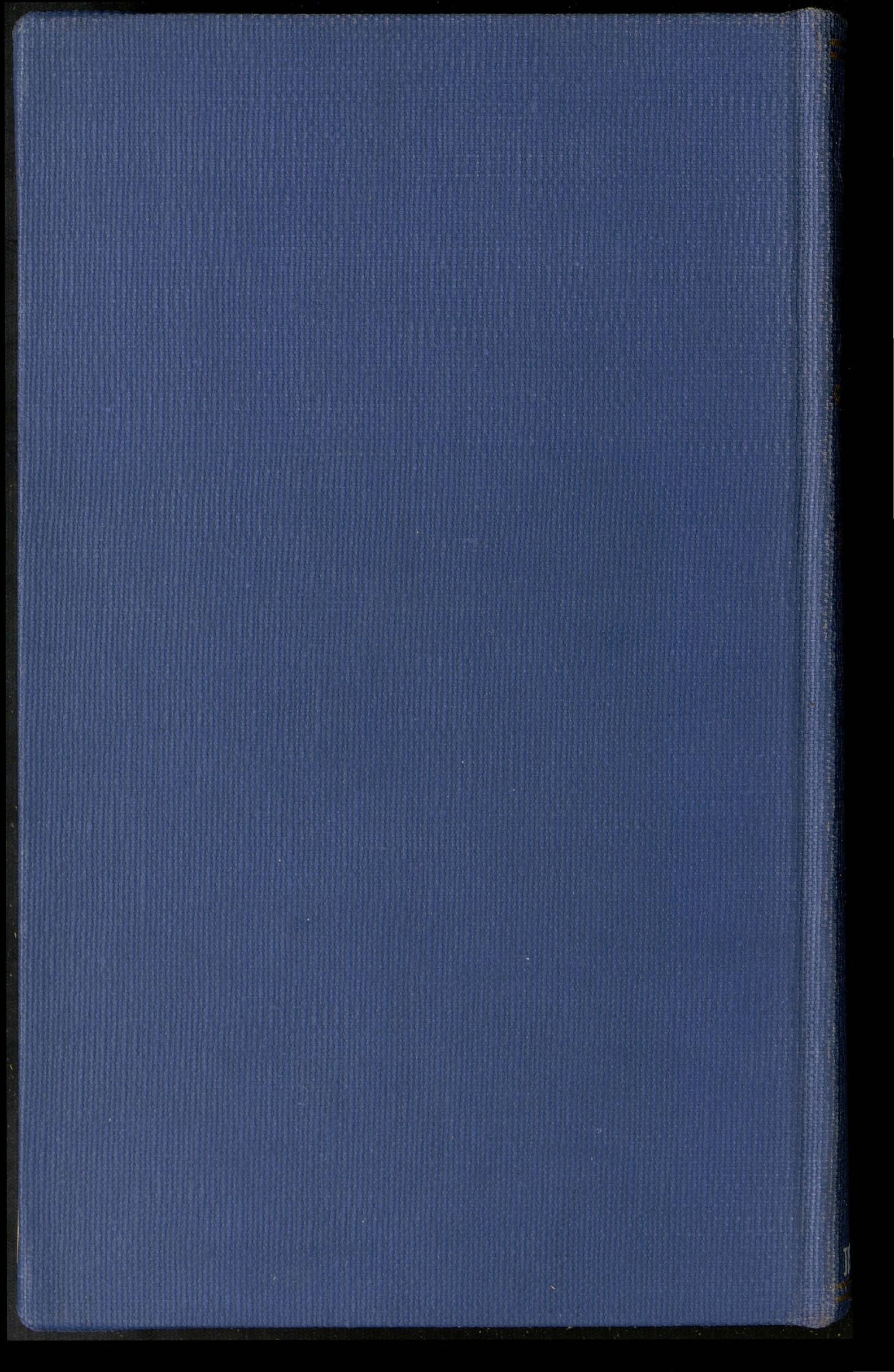

